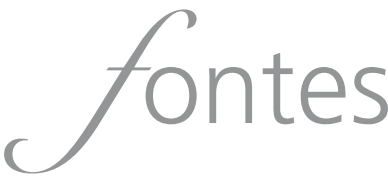

Jaime Rodrigues

Universidade Federal de São Paulo

jaime.rodrigues@eunifesp.br

Marcia Eckert Miranda Universidade Federal de São Paulo mmiranda@unifesp.br

Denilson Botelho Universidade Federal de São Paulo denilson.botelho@unifesp.br

\section{0 acervo de prontuários do Manicômio Judiciário do Estado de São Paulo (1903- 1930)}

0 instrumento de pesquisa aqui apresentado resulta de projeto desenvolvido no âmbito do Programa de Educação Tutorial do curso de História da Universidade Federal de São Paulo (PET-História), em parceria com o Arquivo Público do Estado de São Paulo (APESP), entre 2012 e 2015, junto ao acervo do Manicômio Judiciário. Entre outras, o PET-História realiza atividades voltadas à reflexão, pesquisa e disponibilização de fontes documentais em suas diferentes dimensões e tipologias ${ }^{1}$.

A trajetória do acervo em questão é singular. A história da "assistência aos psicopatas" - expressão pela qual a Psiquiatria institucionalizou-se junto aos poderes públicos - em São Paulo, iniciase em 1852. Naquele ano, foi criado um hospício na então Rua de São João, mantido por religiosos e administrado pelo padre Vicente Pires da Mota. Em 1864, o hospício foi transferido para a Várzea do Carmo, no final da Ladeira Tabatinguera (em edificação ainda hoje existente), agora sob a gestão do doutor Thomé de Alvarenga. Apenas no início do século XX, mais precisamente em 1904, foi inaugurado o Hospício Central do Juquery, no atual município de Franco da Rocha, sendo para lá transferidos os internos da capital, sob a orientação intelectual do psiquiatra Francisco Franco da Rocha². Parte do complexo do Juquery passou a abrigar, também, um manicômio destinado à internação dos condenados pela Justiça diagnosticados como doentes mentais. A separação institucional e a criação do Manicômio Judiciário do Estado de São Paulo, oficialmente chamado Hospital de Custódia e Tratamento Psiquiátrico Professor André Teixeira Lima, data de 1927.

Esse manicômio abrigou pacientes de ambos os sexos - ainda que

\footnotetext{
1 Petianos que participaram da coleta de dados do projeto entre 2012 e 2015: Alexandre Queiroz de Oliveira, Alice Reis Silva, Amanda da Silva Brito, Amanda Leisa Martins da Silva, Ana Gabriela da Silva Santos, Augusto Nalini Aigner de Paula, Bianca Jaqueline de Moraes Vicente, Brunno Henrique Moura, Bruno Felipe Ferreira Inocencio, Felipe Garcia de Oliveira, Gabriela Moreira de Almeida, Gabrielle Ramos da Silva, Guilherme Fernandes de Moura, Jaine Aparecida Diniz, Joaquim Wellington Ferreira, Juliana Saez de Carvalho, Katheryn Silveira Wiganckow, Larissa Alves de Lima, Mariana Soares Popperl, Marina Passos Tufolo, Maurício Dias Duarte, Michelle Carolina de Britto, Mirna Brito Santana, Rafaela Cristina da Silva, Thaís Aparecida Fogaça, Tuanny F. Antunes Lanzellotti e Vinícius Lourenço Barbosa.

2 Para uma história dessa instituição e de seu idealizador, ver Maria Clementina Pereira Cunha. O espelho do mundo: Juquery, a história de um hospício. Rio de Janeiro: Paz e Terra, 1986.
} 
os prontuários de mulheres sejam em número muito reduzido quando comparados aos dos homens. A instituição também mudou de designação e de lugar no organograma do governo estadual. Uma das inúmeras transformações foi a mudança de nome, em 1988, quando passou a ser chamado de Hospital de Custódia, dois anos após ser criado, ali, um sistema de "colônias", numa área até então pertencente ao Hospital do Juquery.

Hoje, o órgão está ligado à Secretaria de Administração Penitenciária e seu nome homenageia André Teixeira Lima (1902-1987), que dirigiu o hospital ao longo de três décadas e é tido como um dos pioneiros da psiquiatria forense em São Paulo. Formado em 1926, pela Faculdade de Medicina e Cirurgia de São Paulo, passou a cuidar da "assistência aos psicopatas" em 1933, a convite de Antonio Carlos Pacheco e Silva, quando este dirigia o Juquery³. Aos seus cuidados, ficaram 104 internos do Hospital Psiquiátrico do Juquery e os que para lá fossem encaminhados pela Justiça, a partir dessa data, para cumprir suas penas e receber assistência. Desde 1956, Teixeira Lima tornara-se também professor de Psicologia Médica e Clínica Psiquiátrica na Faculdade de Medicina de Sorocaba, vinculada à Pontifícia Universidade Católica de São Paulo, onde alcançou o grau de professor titular em $1981^{4}$.

Na virada dos séculos XX/XXI, depois de anos de padecimento, parte do arquivo do Hospício do Juquery incendiou-se e, com isso, perderam-se inúmeros prontuários dos internos que ali viveram boa parte de suas existências. 0 episódio lançou luzes sobre o acervo do Manicômio Judiciário que, além de vizinho e similar em termos arquivísticos e de registro de experiências humanas, corria o mesmo risco em razão do local onde estava acondicionado.

E, como não era difícil prever, em que pese o empenho por parte da equipe de documentalistas da Secretaria de Administração Penitenciária, um princípio de incêndio ocorrido em 2012, em uma das instalações do Manicômio Judiciário, chamou a atenção do APESP que, após avaliação pelos técnicos do Sistema de Arquivos do Estado de São Paulo (SAESP), providenciou o recolhimento dos prontuários ao seu acervo permanente.

Nem todo o material foi recolhido ao APESP. Tiveram esse destino 2.252 prontuários, acondicionados em 380 caixas-arquivos, com datas limites entre 1897 e 1952 (considerando-se 0 ano inicial da internação, pois em meio aos prontuários, a documentação chega até anos mais recentes). Os documentos encontravam-se higienizados e bem acondicionados, o que permitiu o início imediato da descrição e catalogação pela equipe do PET-História.

Em dezembro de 2012, em reunião com o então coordenador do APESP, Prof. Dr. Carlos de Almeida Prado Bacellar, e membros da equipe responsável pelo acervo histórico, lançamos as bases para a parceria. A proposta era inserir, em planilha, as informações seriadas constantes dos prontuários, que constituem uma única série ou "sequência de unidades de um mesmo tipo documental"s. Procedemos à coleta de dados, por amostragem, e estabelecemos os seguintes campos:

\footnotetext{
3 Idem.

4 Helio Begliomini. Academia de Medicina de São Paulo. Cadeira no 103 - Patrono - André Teixeira Lima. Disponível em http://www.academiamedicinasaopaulo.org.br/ biografias/13/BIOGRAFIA-ANDRE-TEIXEIRA-LIMA.pdf.

5 Cf. Ana Maria de Almeida Camargo e Heloísa Liberalli Bellotto. Dicionário de terminologia arquivística. São Paulo: AAB/Núcleo São Paulo; DEMA, 1996, p. 69.
} 


\begin{tabular}{|c|c|}
\hline $\begin{array}{l}\text { No do prontuário } \\
\text { No da caixa } \\
\text { Nome do interno }{ }^{1} \\
\text { Vulgo } \\
\text { Sexo } \\
\text { Data de nascimento } \\
\text { Data de internação } \\
\text { Idade } \\
\text { Dados étnicos (cor) } \\
\text { Naturalidade } \\
\text { Nacionalidade } \\
\text { Estado Civil } \\
\text { Profissão } \\
\text { Religião } \\
\text { Instrução } \\
\text { Pai² }\end{array}$ & $\begin{array}{l}\text { Mãe }{ }^{3} \\
\text { Procedência } \\
\text { Finalidade da internação } \\
\text { Delito } \\
\text { Reincidência } \\
\text { No de internações } \\
\text { Data de Saída } \\
\text { Destino (em caso de saída) } \\
\text { Documentos de identificação (fotografias, } \\
\text { impressões digitais etc.) } \\
\text { Exames psíquicos e evolução (cronologia) } \\
\text { Diagnóstico } \\
\text { Observações }\end{array}$ \\
\hline
\end{tabular}

Dando continuidade aos trabalhos, a planilha foi simplificada e estabelecemos um recorte temporal em meio ao conjunto, descrevendo os prontuários produzidos durante a Primeira República (até 1930), considerando a data de internação dos indivíduos, resultando em 346 unidades.

A partir de inserção das informações na planilha, numerosos estudos de caso temáticos começam a se tornar possíveis. Os estudantes do PET-História produziram textos analíticos, a partir de escolhas e recortes aos quais chegaram graças à existência da planilha que eles próprios elaboraram. Relacionamos, abaixo, os títulos desses textos, que encontram-se em análise por diversos periódicos, para fins de publicação.

- Larissa Alves de Lima; Vinícius Lourenço Barbosa; Vitor Paffile e Thaís Aparecida Fogaça.

"Na expectativa de breve resposta: uma análise da comunicação epistolar entre o Manicômio Judiciário de São Paulo e a família do intern";

- Brunno Henrique Moura; Joaquim Ferreira Wellington e Mariana Soares Popperl. "Belas, recatadas e loucas: as mulheres do Manicômio Judiciário de São Paulo";

- Augusto Nalini Aigner de Paula e Marina Passos Tufolo. "O diagnóstico da norma: práticas e problemas de definição da doença mental nos prontuários do Manicômio Judiciário";

- Augusto Nalini Aigner de Paula. "Os prontuários do Manicômio Judiciário do Estado de São Paulo (1897-1930) como fonte para o historiador: possibilidades e limitações";

- Elias Santos Jr. e Mirna Brito Santana. "Honra e crime passional no Manicômio Judiciário de São Paulo (1900-1930)";

- Bianca Jaqueline de Moraes Vicente; Gabrielle Ramos da Silva; Gabriela Moreira de Almeida e Guilherme Fernandes de Moura. "A perspectiva do interno no Manicômio Judiciário de São Paulo: breve estudo sobre cartas (1910-1923)". 
Simplificada em sua apresentação, a planilha que se segue é composta das seguintes colunas:

1. No do prontuário: repete o número que consta na caixa no APESP;

2. Iniciais do nome do interno;

3. Sexo (masculino - M ou feminino - F);

4. Idade (no momento da internação);

5. Cor (conforme mencionada, apontando eventuais diferenças ao longo do prontuário);

6. Nacionalidade;

7. Naturalidade (sempre que possível, indicando cidade, estado ou província e país, neste último caso, quando se tratar de estrangeiro);

8. Estado civil;

9. Profissão;

10. Religião;

11. Instrução (indicando o grau de letramento);

12. Procedência (indicando a instituição ou o município de onde o interno provém, que muitas vezes não é o mesmo de onde é natural. Geralmente, trata-se do local onde foi preso, onde foi condenado, onde vivia, etc.);

13. Data de entrada/ internação;

14. Data de saída;

15. Motivo da saída;

16. Identificação (meios de identificação contidos nos documentos do prontuário, tais como fotografia, digitais e assinatura do interno).

17. Diagnóstico;

18. Condição (refere-se ao crime que teria levado o interno ao manicômio);

19. Observações (tudo o que não couber nos campos anteriores e for notado no processo de coleta das informações).

A diagramação da planilha para o formato da revista pode causar alguma dificuldade na leitura dos dados. Os autores dispõem-se a enviar a planilha em formato Excel aos interessados, bastando para isso fazer uma solicitação por correio eletrônico.

(Footnotes)

1 Claro está que, pela natureza das informações constantes nos prontuários e por sua temporalidade relativamente recente, alguns pacientes e/ou seus familiares podem estar vivos. Dessa forma, o procedimento ético que nos pareceu mais apropriado foi utilizar abreviaturas em vez de discriminar os nomes completos, ao tornar público o instrumento de pesquisa. 0 procedimento adotado pelo APESP, em situacões semelhantes, tem sido o de permitir o acesso aos documentos, com base no que a Constituição e leis regulamentadoras definem, mediante um documento assinado pelo consulente, por meio do qual o mesmo se responsabiliza pelo uso que der às informações, desonerando a instituição de qualquer responsabilidade.

2 Cabe aqui o mesmo procedimento referido no nome do interno.

3 Cabe aqui o mesmo procedimento referido no nome do interno. 


\begin{tabular}{|c|c|c|c|c|c|c|c|c|c|c|c|c|c|c|c|c|c|c|}
\hline 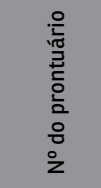 & 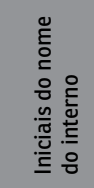 & ֻั̊ & 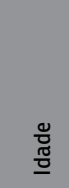 & ¿̀ & $\begin{array}{l}\frac{\pi}{\pi} \\
\frac{\pi}{0} \\
\frac{\pi}{\pi} \\
\frac{0}{0} \\
\frac{\pi}{2} \\
\frac{\pi}{2}\end{array}$ & 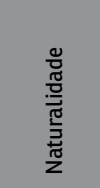 & 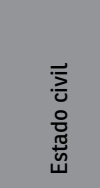 & 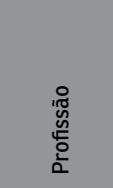 & 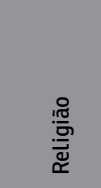 & 蕥 & 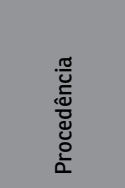 & 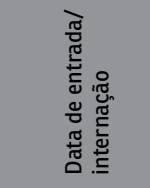 & $\begin{array}{l}\frac{\pi}{0} \\
\frac{\pi}{\pi} \\
0 \\
0 \pi \\
\frac{\pi}{\pi} \\
0\end{array}$ & 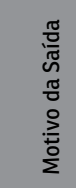 & 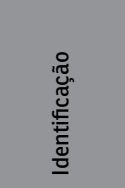 & 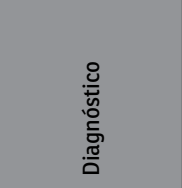 & 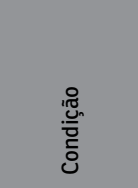 & 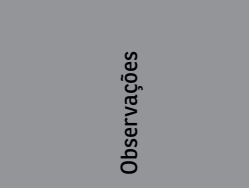 \\
\hline DAP 356 & R.A. & M & 41 & Branca & Italiana & Itália & Casado & & Católica & & $\begin{array}{l}\text { Cadeia } \\
\text { Pública da } \\
\text { Capital, } \\
\text { SP }\end{array}$ & $\begin{array}{l}\text { 29/05/1903 е } \\
06 / 02 / 1906\end{array}$ & & & Fotografia & Sifilítico & & \\
\hline DAP 082 & B.S. & M & 39 & Branca & Italiana & Itália & Casado & & & $\begin{array}{l}\text { Alfabeti- } \\
\text { zado (não } \\
\text { frequentou } \\
\text { escola) }\end{array}$ & $\begin{array}{l}\text { São Ro- } \\
\text { que, SP }\end{array}$ & $11 / 11 / 1903$ & $9 / 22 / 1941$ & Óbito & $\begin{array}{l}\text { Fotografia, } \\
\text { digitais, } \\
\text { arcada } \\
\text { dentária } \\
\text { e medidas } \\
\text { corporais }\end{array}$ & $\begin{array}{l}\text { Excitação } \\
\text { maníaca }\end{array}$ & & $\begin{array}{l}\text { Casou-se aos } 25 \text { anos, } \\
\text { teve } 5 \text { filhos, } 2 \text { fale- } \\
\text { cidos. Seus parentes } \\
\text { encontram-se na } \\
\text { Europa, não mantém } \\
\text { relação com eles. Passa } \\
\text { a maior parte do tempo } \\
\text { em laborterapia. Tem } \\
\text { boa noçāo de tempo e } \\
\text { espaço. Afirma já ter } \\
\text { visto espíritos. }\end{array}$ \\
\hline DAP 065 & A.N. & M & 35 & Branca & Italiana & $\begin{array}{l}\text { Calábria, } \\
\text { Itália }\end{array}$ & Solteiro & Pedreiro & Católica & Ignorada & & $12 / 1 / 1903$ & $12 / 7 / 1932$ & Óbito & $\begin{array}{l}\text { Assi- } \\
\text { natura, } \\
\text { fotografia } \\
\text { e medidas } \\
\text { corporais. }\end{array}$ & $\begin{array}{l}\text { Estigma de de- } \\
\text { generação psí- } \\
\text { quica, síndrome } \\
\text { paranóide }\end{array}$ & $\begin{array}{l}\text { Senten- } \\
\text { ciado (art. } \\
356 \text { ) a } 12 \\
\text { anos de } \\
\text { prisão, } \\
\text { combinado } \\
\text { com o art. } \\
358, \text { a pena } \\
\text { de } 8 \text { anos } \\
\text { de prisão } \\
\text { celular. }\end{array}$ & $\begin{array}{l}\text { Membro de quadritha } \\
\text { de salteadores de São } \\
\text { Carlos do Pinhal. Tem } \\
\text { boa noção de tempo, } \\
\text { espaço e memória. }\end{array}$ \\
\hline DAP 139 & E.A.P. & M & 21 & Branca & Brasileira & & Solteiro & $\begin{array}{l}\text { Soldado } \\
\text { da polícia }\end{array}$ & Católica & & & $12 / 10 / 1903$ & $11 / 22 / 1906$ & Alta & $\begin{array}{l}\text { Medidas } \\
\text { corporais }\end{array}$ & $\begin{array}{l}\text { Síndrome para- } \\
\text { nóide, delírios } \\
\text { de perseguição }\end{array}$ & Réu & $\begin{array}{l}\text { Pai vivo, mãe falecida } \\
\text { havia doze anos. Teve } \\
7 \text { irmão, } 5 \text { dos quais } \\
\text { sobreviveram. Boa } \\
\text { memória. Tentativa de } \\
\text { homicídio. }\end{array}$ \\
\hline DAP 206 & J.G.M. & M & 35 & Branca & Brasileira & & Viúvo & Ignorada & Ignorada & & Jaú, MG & $5 / 8 / 1904$ & $1 / 21 / 1932$ & Alta & & $\begin{array}{l}\text { Demência } \\
\text { paranóide }\end{array}$ & $\begin{array}{l}\text { Réu (art. } \\
294 \text { do } \\
\text { Código Pe- } \\
\text { nal, } \$ 2^{\circ} \text { ). } \\
\text { Absolvido. }\end{array}$ & $\begin{array}{l}\text { Apesar da idade, } \\
\text { conservava sua } \\
\text { esfera intelectual, não } \\
\text { apresentando deĺriose } \\
\text { distúrbios psicosenso- } \\
\text { riais. Trabalhava com } \\
\text { relativa eficiencia e, em } \\
\text { decorrência disso, o } \\
\text { julgaram apto a voltar } \\
\text { a viver com a família. }\end{array}$ \\
\hline
\end{tabular}




\begin{tabular}{|c|c|c|c|c|c|c|c|c|c|c|c|c|c|c|c|c|c|c|}
\hline 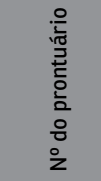 & 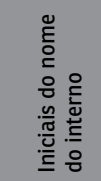 & ๙̊̀̃ & 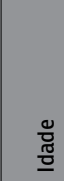 & ¿̀ & $\begin{array}{l}\frac{.0}{\pi} \\
\frac{\pi}{\bar{T}} \\
\frac{\pi}{\pi} \\
\frac{0}{\bar{L}} \\
\frac{\pi}{2}\end{array}$ & 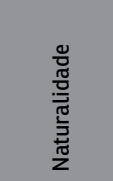 & 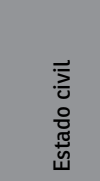 & 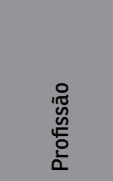 & : & 突 & 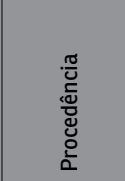 & 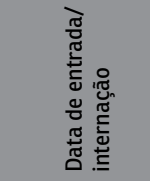 & $\begin{array}{l}\frac{\pi}{0} \\
\frac{\pi}{0} \\
\frac{\pi}{\pi} \\
\frac{\pi}{\pi} \\
0\end{array}$ & 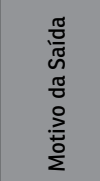 & 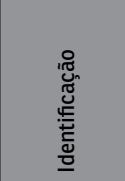 & 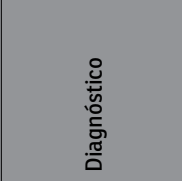 & 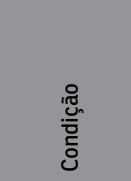 & 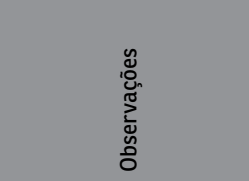 \\
\hline DAP 282 & L.B.G. & M & 40 & Branca & Brasileira & $\begin{array}{l}\text { Vila de } \\
\text { Concei- } \\
\text { ção }\end{array}$ & Casado & $\begin{array}{l}\text { Nego- } \\
\text { ciante }\end{array}$ & Católica & $\begin{array}{l}\text { Alfabeti- } \\
\text { zado (não } \\
\text { frequentou } \\
\text { escola) }\end{array}$ & $\begin{array}{l}\text { São Paulo, } \\
\text { SP }\end{array}$ & 7/27/1904 & 9/7/1934 & Óbito & $\begin{array}{l}\text { Fotografia, } \\
\text { digitais e } \\
\text { medidas } \\
\text { corporais }\end{array}$ & $\begin{array}{l}\text { Síndrome de } \\
\text { influência, en- } \\
\text { fraquecimento } \\
\text { global mental, } \\
\text { demência para- } \\
\text { nóide e delíiios } \\
\text { de perseguição }\end{array}$ & Réu & $\begin{array}{l}\text { Tentativa de homicídio. } \\
\text { Devido a um incêndio } \\
\text { no fórum, não é possí- } \\
\text { vel definir sua situação } \\
\text { legal. O pai esteve no } \\
\text {,anicômio, um irmão } \\
\text { bebe e é agressivo. } \\
\text { Tinha } 4 \text { filhos. Bebia } \\
\text { muito. Noçãa de tempo, } \\
\text { mas não de espaço. }\end{array}$ \\
\hline DAP 240 & J.C.N. & $M$ & 38 & Parda & & & Solteiro & Ignorada & & & Ignorada & $12 / 4 / 1904$ & $2 / 2 / 1932$ & $\begin{array}{l}\text { Trans- } \\
\text { ferência } \\
\text { para o } \\
\text { Hospital } \\
\text { do Ju- } \\
\text { query }\end{array}$ & & Mania & $\begin{array}{l}\text { Condenado } \\
\text { a } 6 \text { anos } \\
\text { de prisão } \\
\text { celular. }\end{array}$ & $\begin{array}{l}\text { Transferido para a ala } \\
\text { de doentes comuns em } \\
\text { 02/02/1932. }\end{array}$ \\
\hline DAP 156 & F.C. & M & 45 & Branca & Italiana & $\begin{array}{l}\text { Milāo, } \\
\text { Itáliaa }\end{array}$ & Casado & $\begin{array}{l}\text { Ajudante } \\
\text { de ferreiro }\end{array}$ & Católica & Alfabetizado & & $\begin{array}{l}\text { 25/07/1905 e } \\
29 / 11 / 1906\end{array}$ & & & $\begin{array}{l}\text { Medidas } \\
\text { corporais, } \\
\text { fotografia, } \\
\text { assinatura }\end{array}$ & $\begin{array}{l}\text { Demência } \\
\text { paralítica }\end{array}$ & Réu & $\begin{array}{l}\text { Terrores noturnos dos } \\
8 \text { aos } 16 \text { anos de idade. } \\
\text { Dois filhos, um morto } \\
\text { na Itália. Boa noção de } \\
\text { tempo e espaço. }\end{array}$ \\
\hline DAP 384 & T.A. & M & 29 & Branca & Italiana & Itália & Solteiro & & & & & $7 / 25 / 1905$ & $12 / 2 / 1905$ & Óbito & & Sifilítico & & \\
\hline DAP 393 & V.G.S. & M & 18 & Branca & Brasileira & $\begin{array}{l}\text { São Pau- } \\
\text { lo, SP }\end{array}$ & Solteiro & & & & & $8 / 12 / 1905$ & $3 / 13 / 1908$ & Óbito & $\begin{array}{l}\text { Fotografia } \\
\text { e medidas } \\
\text { corporais }\end{array}$ & Imbecilidade & & $\begin{array}{l}\text { Noção imperfeita de es- } \\
\text { paço e noção de tempo } \\
\text { muito vaga. }\end{array}$ \\
\hline DAP 171 & G.N. & $M$ & 58 & Branca & Italiana & $\begin{array}{l}\text { São Ber- } \\
\text { nardo, } \\
\text { Itália }\end{array}$ & Casado & Sapateiro & Católica & & & 9/6/1905 & $25 / 05 / 1907$ & Alta & $\begin{array}{l}\text { Medidas } \\
\text { corporais } \\
\text { e assina- } \\
\text { tura }\end{array}$ & $\begin{array}{l}\text { Epilepsia } \\
\text { psíquica }\end{array}$ & Réu & $\begin{array}{l}\text { Seis filhos. Embriaga- } \\
\text { va-se algumas vezes. } \\
\text { Noção exata de tempo } \\
\text { e espaço. Atacou uma } \\
\text { companheira com en- } \\
\text { xada, porque ela teria } \\
\text { ferido sua reputaçāo. }\end{array}$ \\
\hline DAP 293 & M.M. & $M$ & 28 & Preta & Brasileira & & Casado & & & & & 9/6/1905 & $2 / 12 / 1906$ & Óbito & & $\begin{array}{l}\text { Loucura } \\
\text { maníaco } \\
\text { depressiva, com } \\
\text { predominância } \\
\text { assinalada de } \\
\text { estado melan- } \\
\text { cólico }\end{array}$ & $\begin{array}{l}\text { Réu por } \\
\text { ferimen- } \\
\text { tos leves } \\
\text { em uma } \\
\text { pessoa. }\end{array}$ & \\
\hline
\end{tabular}




\begin{tabular}{|c|c|c|c|c|c|c|c|c|c|c|c|c|c|c|c|c|c|c|}
\hline 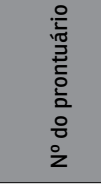 & 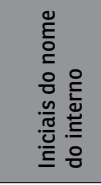 & ๖ัे & $\begin{array}{l}\text { 营 } \\
\text { 은 }\end{array}$ & ¿̀ & $\begin{array}{l}\frac{0}{\pi} \\
\frac{\pi}{0} \\
\overline{0} \\
\frac{\pi}{0} \\
\frac{0}{\pi} \\
\frac{\pi}{2}\end{array}$ & 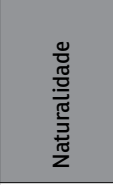 & 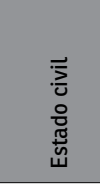 & 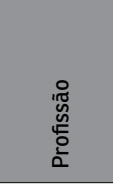 & $\begin{array}{l}0 \\
\frac{\pi}{\pi} \\
\frac{\pi}{\pi} \\
\frac{\pi}{\pi}\end{array}$ & 㝕 & 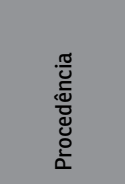 & 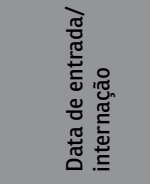 & $\begin{array}{l}\frac{\pi}{0} \\
\frac{\pi}{\pi} \\
0 \\
0 \\
\frac{\pi}{\pi} \\
0\end{array}$ & 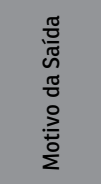 & 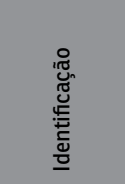 & 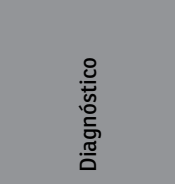 & 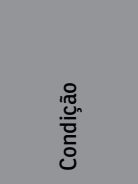 & 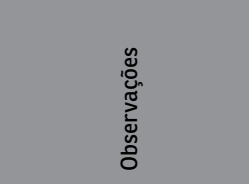 \\
\hline l & T.A. & M & 38 & Branca & Italiana & Itália & Solteiro & Lavrador & Católica & Analfabeto & $\begin{array}{l}\text { Araraqua- } \\
\text { ra, SP }\end{array}$ & $6 / 10 / 1906$ & 2/2/1932 & $\begin{array}{l}\text { Trans- } \\
\text { ferência } \\
\text { para o } \\
\text { Hospital } \\
\text { do Ju- } \\
\text { query }\end{array}$ & Fotografia & $\begin{array}{l}\text { Sintoma para- } \\
\text { nóide, delírio } \\
\text { de perseguiçāo }\end{array}$ & $\begin{array}{l}\text { Réu (art. } \\
294 \text { do } \\
\text { Código } \\
\text { Penal, } \$ 1 \\
\text { do Código } \\
\text { Penal). }\end{array}$ & $\begin{array}{l}\text { Diz ser casado na Itália. } \\
\text { Não foi processsado } \\
\text { por ser irresponsável. } \\
\text { Assassinou seu patrão, } \\
\text { em Matão-SP, por não } \\
\text { pagar o salário. Diz } \\
\text { não saber o crime que } \\
\text { cometeu. }\end{array}$ \\
\hline DAP 194 & J.B.M. & M & 30 & Branca & Italiana & $\begin{array}{l}\text { Santa } \\
\text { Rita do } \\
\text { Passa } \\
\text { Quatro, } \\
\text { SP }\end{array}$ & Solteiro & $\begin{array}{l}\text { Comer- } \\
\text { cian-te }\end{array}$ & Católica & & & $7 / 26 / 1906$ & 6/27/1907 & & $\begin{array}{l}\text { Assina- } \\
\text { tura }\end{array}$ & $\begin{array}{l}\text { Loucura men- } \\
\text { tal, neurastenia }\end{array}$ & Réu & $\begin{array}{l}\text { Não sabia explicar o } \\
\text { crime que cometeu. }\end{array}$ \\
\hline DAP 137 & E.B.C.F. & M & 23 & Branca & Brasileira & Jaú, SP & Solteiro & Lavrador & Católica & & & 9/5/1906 & & & Fotografia & $\begin{array}{l}\text { Delírio de } \\
\text { perseguição, } \\
\text { epileptóide, fra- } \\
\text { co de espirito, } \\
\text { com sintoma } \\
\text { paranóide }\end{array}$ & & $\begin{array}{l}\text { Afirma ter cometido } \\
\text { crime de mortee em } \\
\text { legitima defesa em Jaú. }\end{array}$ \\
\hline DAP 051 & A.C.G. & M & 38 & Branca & Brasileira & $\begin{array}{l}\text { Ceará-Mi- } \\
\text { rim, RN }\end{array}$ & Casado & $\begin{array}{l}\text { Alferes da } \\
\text { polícia }\end{array}$ & Católica & & $\begin{array}{l}\text { Casa } \\
\text { Branca, SP }\end{array}$ & 9/15/1906 & 2/7/1913 & Cura & Fotografia & $\begin{array}{l}\text { Sifilítico, delírio } \\
\text { de grandeza, } \\
\text { megalomaní- } \\
\text { aco, manifesta } \\
\text { euforia, } \\
\text { completa falta } \\
\text { de relaçōes } \\
\text { entre as ideias } \\
\text { e alienaçāo }\end{array}$ & & $\begin{array}{l}\text { No "Lugar para o } \\
\text { autógrafo", há um texto } \\
\text { escrito pelo interno em } \\
\text { 03/09/1906. }\end{array}$ \\
\hline DAP 047 & A.B.R. & M & 45 & Morena & Brasileira & & Casado & $\begin{array}{l}\text { Telegra- } \\
\text { fista }\end{array}$ & Católica & & & $\begin{array}{l}27 / 10 / 1906 \text { e } \\
22 / 11 / 1908\end{array}$ & & Óbito & Fotografia & Sifilítico & & $\begin{array}{l}\text { Diz ter dado facadas } \\
\text { em um guarda, por ter } \\
\text { sido agredido anterior- } \\
\text { mente. }\end{array}$ \\
\hline DAP 071 & A.S. & M & 40 & Branca & Italiana & $\begin{array}{l}\text { Catanza- } \\
\text { ro, Itália }\end{array}$ & Casado & Roceiro & Católica & & $\begin{array}{l}\text { Cadeia } \\
\text { Pública da } \\
\text { Capital, } \\
\text { SP }\end{array}$ & 12/7/1907 & $10 / 21 / 1931$ & Óbito & Fotografia & $\begin{array}{l}\text { Sifilítico, } \\
\text { epileptóide em } \\
\text { fase demencial, } \\
\text { degenerado }\end{array}$ & $\begin{array}{l}\text { Condena- } \\
\text { do a } 25 \\
\text { anos por } \\
\text { assassinato } \\
\text { (art. 294 } \\
\text { do Código } \\
\text { Penal, } \$ 1^{\circ} \\
\text { do Código } \\
\text { Penal). }\end{array}$ & \\
\hline
\end{tabular}




\begin{tabular}{|c|c|c|c|c|c|c|c|c|c|c|c|c|c|c|c|c|c|c|}
\hline 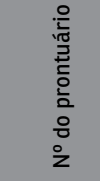 & 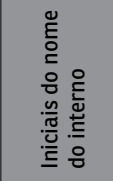 & ঙ̊̊̆ & 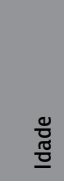 & ¿̀ & $\begin{array}{l}\frac{2}{\pi} \\
\frac{\pi}{0} \\
\frac{\pi}{\pi} \\
\frac{0}{0} \\
\frac{0}{2} \\
\frac{\pi}{2}\end{array}$ & 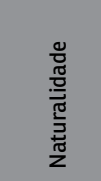 & 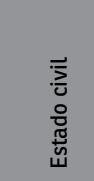 & 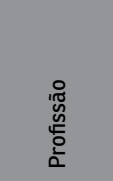 & : & 空 & 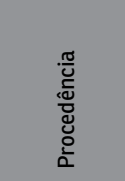 & 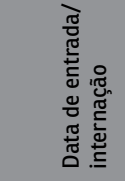 & 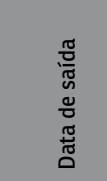 & 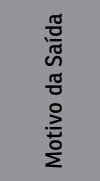 & 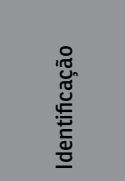 & 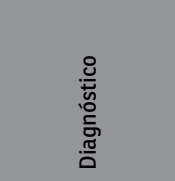 & 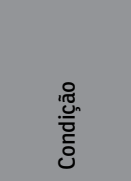 & 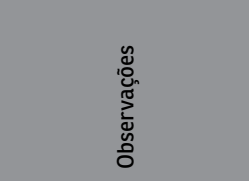 \\
\hline DAP 390 & V.B.A. & M & 35 & Branca & Brasileira & $\begin{array}{l}\text { São } \\
\text { Gabriel, } \\
\text { RS }\end{array}$ & Solteiro & & & & $\begin{array}{l}\text { Cadeia } \\
\text { Pública da } \\
\text { Capital, } \\
\text { SP }\end{array}$ & 12/8/1907 & & & Fotografia & $\begin{array}{l}\text { Sifilítico, alie- } \\
\text { nação mental, } \\
\text { possessão espi- } \\
\text { ritual, concep- } \\
\text { ção delusória } \\
\text { de perseguição, } \\
\text { demência } \\
\text { paranóide }\end{array}$ & & $\begin{array}{l}\text { Pede para rever sua } \\
\text { sentença, por se redi- } \\
\text { mir de seus atos. Lutou } \\
\text { ao lado dos legalistas } \\
\text { na Revolução do Rio } \\
\text { Grande. Mudou-se para } \\
\text { São Paulo e foi senten- } \\
\text { ciado, por introduçāa } \\
\text { dolosa, circulaçāo de } \\
\text { dinheiro falso. }\end{array}$ \\
\hline DAP 215 & J.P.C. & M & 28 & Branca & Brasileira & $\begin{array}{l}\text { Guaim- } \\
\text { ba da } \\
\text { Canoa, } \\
\text { MG }\end{array}$ & Solteiro & $\begin{array}{l}\text { Traba- } \\
\text { lhador da } \\
\text { roça }\end{array}$ & Católica & & Franca, SP & 4/16/1908 & 2/2/1932 & $\begin{array}{l}\text { Trans- } \\
\text { ferência } \\
\text { para o } \\
\text { Hospital } \\
\text { do Ju- } \\
\text { query } \\
\end{array}$ & Fotografia & $\begin{array}{l}\text { Imbecil-epitep- } \\
\text { tóide }\end{array}$ & $\begin{array}{l}\text { Condenado } \\
\text { por ter } \\
\text { matado } \\
\text { o pai }\end{array}$ & \\
\hline DAP 200 & $\begin{array}{l}\text { J.C.C. } \\
\text { (vulgo } \\
\text { João } \\
\text { Mariano) }\end{array}$ & M & 25 & Morena & Brasileira & $\begin{array}{l}\text { Serra } \\
\text { Azul, SP }\end{array}$ & Solteiro & Lavrador & & Alfabetizado & Franca, SP & 4/16/1908 & $2 / 2 / 1932$ & & & & $\begin{array}{l}\text { Réu (art. } \\
\text { 29). }\end{array}$ & $\begin{array}{l}\text { Recolhido sob a ale- } \\
\text { gação de interesse da } \\
\text { segurança pública por } \\
\text { "sofrer da perturbação } \\
\text { mental com momentos } \\
\text { lúcidos", tendo se } \\
\text { tornado perigoso à } \\
\text { sociedade. Consta em } \\
\text { carta que foi submetido } \\
\text { a exames diversos. }\end{array}$ \\
\hline DAP 078 & B.M. & M & 25 & Parda & Brasileira & & Solteiro & $\begin{array}{l}\text { Sem } \\
\text { profissão }\end{array}$ & Católica & & $\begin{array}{l}\text { Colônia } \\
\text { Correcio- } \\
\text { nal }\end{array}$ & $8 / 1 / 1908$ & $2 / 2 / 1932$ & $\begin{array}{l}\text { Trans- } \\
\text { ferência } \\
\text { para o } \\
\text { Hospital } \\
\text { do Ju- } \\
\text { query }\end{array}$ & $\begin{array}{l}\text { Fotografia } \\
\text { e assina- } \\
\text { tura }\end{array}$ & $\begin{array}{l}\text { Sifilítico e } \\
\text { maníaco } \\
\text { depressivo }\end{array}$ & & \\
\hline DAP 125 & D.C. & M & 46 & Branca & Italiana & & Casado & Carteiro & Católica & Analfabeto & $\begin{array}{l}\text { Peniten- } \\
\text { ciária do } \\
\text { Estado, } \\
\text { SP }\end{array}$ & $10 / 19 / 1908$ & $4 / 6 / 1936$ & Óbito & Fotografia & $\begin{array}{l}\text { Sifilítico, } \\
\text { ilusōes, delírios } \\
\text { de perseguiçāo }\end{array}$ & $\begin{array}{l}\text { Senten- } \\
\text { ciado a } \\
\text { seis anos } \\
\text { de prisão } \\
\text { celular } \\
\text { (art. 294 } \\
\text { do Código } \\
\text { Penal, } \$ 2^{\circ} \\
\text { do Código } \\
\text { Penal). }\end{array}$ & $\begin{array}{l}\text { Veio da Itália, em 1900, } \\
\text { com o propósito de exe- } \\
\text { cutar o seu irmão por } \\
\text { "questão de interesse". }\end{array}$ \\
\hline
\end{tabular}




\begin{tabular}{|c|c|c|c|c|c|c|c|c|c|c|c|c|c|c|c|c|c|c|}
\hline 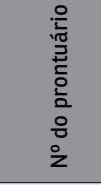 & 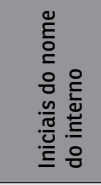 & 今̊ & $\begin{array}{l}\text { 苋 } \\
\text { 吾 }\end{array}$ & ¿̀ & $\begin{array}{l}\frac{8}{\pi} \\
\frac{\pi}{0} \\
\frac{\pi}{\pi} \\
\frac{0}{0} \\
\frac{0}{2} \\
\frac{\pi}{2}\end{array}$ & 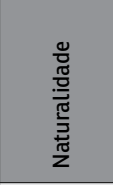 & 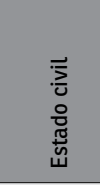 & 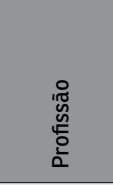 & 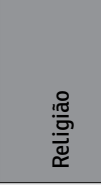 & 㝕 & 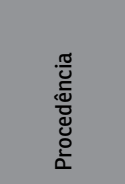 & 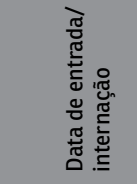 & $\begin{array}{l}\frac{\pi}{0} \\
\frac{\pi}{\pi} \\
0 \\
0 \\
\frac{\pi}{\pi} \\
0\end{array}$ & 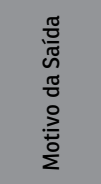 & 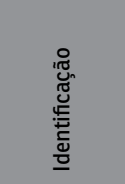 & 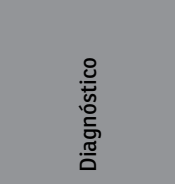 & 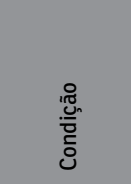 & 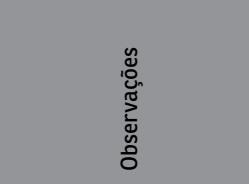 \\
\hline DAP 258 & J.L.P. & M & 30 & Branca & Brasileira & $\begin{array}{l}\text { Botucatu, } \\
\text { SP }\end{array}$ & Solteira & $\begin{array}{l}\text { Accou- } \\
\text { gueiro }\end{array}$ & Maçom & $\begin{array}{l}\text { Alfabetizado } \\
\text { (nāo teve } \\
\text { educação em } \\
\text { colégio) }\end{array}$ & & 2/18/1909 & $2 / 2 / 1932$ & $\begin{array}{l}\text { Trans- } \\
\text { ferência } \\
\text { para o } \\
\text { Hospital } \\
\text { do Ju- } \\
\text { query }\end{array}$ & $\begin{array}{l}\text { Fotografia } \\
\text { e assina- } \\
\text { tura }\end{array}$ & $\begin{array}{l}\text { Degenerado e } \\
\text { epileptóide }\end{array}$ & $\begin{array}{l}\text { Réu (art. } \\
294 \text { do } \\
\text { Código } \\
\text { Penal } 1^{\circ} \text {. }\end{array}$ & $\begin{array}{l}\text { Condenado por ter } \\
\text { matado um amigo, em } \\
28 / 07 / 1907, \text { porém, nāo } \\
\text { lembra do ocorrido. } \\
\text { Entregou-se ao vício da } \\
\text { embriaguese. Exame de } \\
\text { líquido céfalorraqui- } \\
\text { diano. }\end{array}$ \\
\hline DAP 169 & G.G. & M & 37 & Branca & Italiana & $\begin{array}{l}\text { Rovigo, } \\
\text { Itália }\end{array}$ & Casado & Roceiro & & & & $5 / 30 / 1909$ & $2 / 26 / 1940$ & Óbito & $\begin{array}{l}\text { Fotogra- } \\
\text { fia, arcada } \\
\text { dentária, } \\
\text { radio- } \\
\text { grafia do } \\
\text { pulmão }\end{array}$ & $\begin{array}{l}\text { Síndrome } \\
\text { de excitação } \\
\text { maníaca, de- } \\
\text { mência precoce } \\
\text { ebefrênica }\end{array}$ & $\begin{array}{l}\text { Condenado } \\
\text { a } 15 \text { anos } \\
\text { de prisão } \\
\text { (art. 294 } \\
\text { do Código } \\
\text { Penal). }\end{array}$ & $\begin{array}{l}\text { Morreu de insuficiência } \\
\text { cardíaca decorrente de } \\
\text { pneumonia. Exames de } \\
\text { líquido cefalorraquidia- } \\
\text { no, urina, hemocultura, } \\
\text { acompanhamento } \\
\text { clínico e de eletrorra- } \\
\text { diologia. }\end{array}$ \\
\hline DAP368 & S.M.M. & M & 37 & Branca & Brasileira & $\begin{array}{l}\text { Socorro, } \\
\text { SP }\end{array}$ & Solteira & Lavrador & Católica & & $\begin{array}{l}\text { São Paulo, } \\
\text { SP }\end{array}$ & $6 / 3 / 1909$ & & & $\begin{array}{l}\text { Fotografia } \\
\text { e assina- } \\
\text { tura }\end{array}$ & $\begin{array}{l}\text { Imbecil-epitep- } \\
\text { tóide }\end{array}$ & $\begin{array}{l}\text { Preso por } \\
\text { ter matado } \\
\text { o pai. }\end{array}$ & \\
\hline DAP 177 & H.D.F. & M & 19 & Preta & Brasileira & Itu, SP & Solteiro & & Católica & & $\begin{array}{l}\text { Taquari- } \\
\text { tin-ga, SP }\end{array}$ & 9/18/1909 & $5 / 11 / 1910$ & $\begin{array}{l}\text { Trans- } \\
\text { ferência } \\
\text { para o } \\
\text { Hospital } \\
\text { do Ju- } \\
\text { query }\end{array}$ & Fotografia & $\begin{array}{l}\text { Síndrome pa- } \\
\text { ranóide em um } \\
\text { epileptóide }\end{array}$ & $\begin{array}{l}\text { Condenado } \\
\text { por homi- } \\
\text { cídio }\end{array}$ & $\begin{array}{l}\text { Na dedução diagnós- } \\
\text { tica, descreve-se o } \\
\text { crime. Nova entrada, } \\
\text { no Hospício do Juquery, } \\
\text { em } 1932 \text {. }\end{array}$ \\
\hline DAP 228 & J.S. & M & 20 & Branca & Brasileira & $\begin{array}{l}\text { Pinda- } \\
\text { monhan- } \\
\text { gaba, SP }\end{array}$ & Solteiro & Roceiro & Católica & Analfabeto & & $10 / 19 / 1909$ & $2 / 2 / 1932$ & $\begin{array}{l}\text { Trans- } \\
\text { ferência } \\
\text { para o } \\
\text { Hospital } \\
\text { do Ju- } \\
\text { query }\end{array}$ & Fotografia & $\begin{array}{l}\text { Depressão dos } \\
\text { sentimentos, } \\
\text { entrave na } \\
\text { associação de } \\
\text { ideias, langui- } \\
\text { dez psico-mo- } \\
\text { tora, torpor do } \\
\text { pensamento }\end{array}$ & $\begin{array}{l}\text { Sentencia- } \\
\text { do a } 1 \text { ano, } \\
1 \text { mês e } 15 \\
\text { dias de pri- } \\
\text { são celular, } \\
\text { por crimes } \\
\text { de roubo e } \\
\text { fraude em } \\
\text { jogos. }\end{array}$ & \\
\hline DAP 281 & L.N. & M & 32 & Branca & Italiana & $\begin{array}{l}\text { Portenza, } \\
\text { Itália }\end{array}$ & Solteira & Sapateiro & Católica & & $\begin{array}{l}\text { São Paulo, } \\
\text { SP }\end{array}$ & $10 / 20 / 1909$ & $10 / 27 / 1909$ & & Ftografia & $\begin{array}{l}\text { Síndrome con- } \\
\text { fuso alucinótica }\end{array}$ & $\begin{array}{l}\text { Roubou } \\
\text { e matou, } \\
\text { junto com } \\
\text { outros dois } \\
\text { indivíduos, } \\
\text { um "capita- } \\
\text { lista." En- } \\
\text { louqueceu } \\
\text { enquanto } \\
\text { cumpria } \\
\text { pena. }\end{array}$ & Recortes de jornal. \\
\hline
\end{tabular}




\begin{tabular}{|c|c|c|c|c|c|c|c|c|c|c|c|c|c|c|c|c|c|c|}
\hline 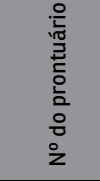 & 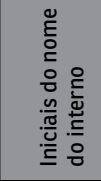 & ֻัे & $\begin{array}{l}\frac{\tilde{g}}{\pi} \\
\underline{\underline{0}}\end{array}$ & ¿̀ & $\begin{array}{l}\frac{\pi}{\pi} \\
\frac{\pi}{\pi} \\
\frac{\pi}{\pi} \\
\frac{0}{4} \\
\frac{\pi}{2} \\
\text { z }\end{array}$ & 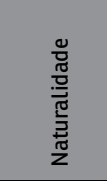 & 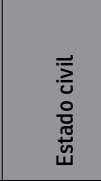 & 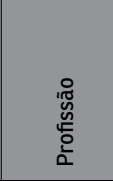 & 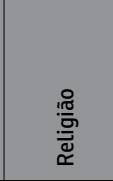 & 空 & 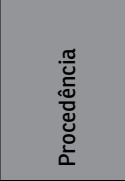 & 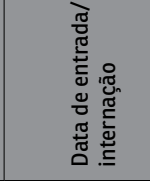 & 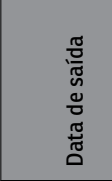 & 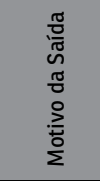 & 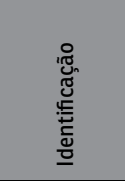 & 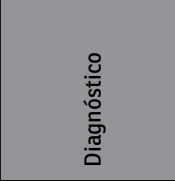 & 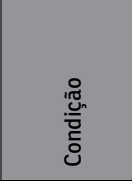 & 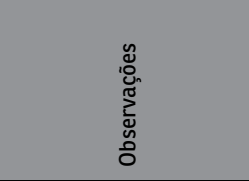 \\
\hline DAP 379 & T.B.L. & M & 48 & Branca & Brasileira & $\begin{array}{l}\text { São José } \\
\text { da Boa } \\
\text { Vista, SP }\end{array}$ & Casado & Lavarista & $\begin{array}{l}\text { Da lei de } \\
\text { Deus }\end{array}$ & & & $11 / 18 / 1909$ & $2 / 2 / 1932$ & $\begin{array}{l}\text { Trans- } \\
\text { ferência } \\
\text { para o } \\
\text { Hospital } \\
\text { do Ju- } \\
\text { query }\end{array}$ & $\begin{array}{l}\text { Fotografia } \\
\text { e escrita }\end{array}$ & $\begin{array}{l}\text { Megalomania, } \\
\text { misticismo, } \\
\text { sifilis }\end{array}$ & $\begin{array}{l}\text { Senten- } \\
\text { ciado a } \\
24 \text { anos } \\
\text { de prisão } \\
\text { simples. }\end{array}$ & $\begin{array}{l}\text { No espaço para a foto, } \\
\text { consta a frase " "ei em } \\
\text { pessoa de Dess". Desde } \\
\text { a infância,apresentou } \\
\text { delírios sustentados } \\
\text { por uma comunicação } \\
\text { divina. Matou um } \\
\text { coronel por ordem de } \\
\text { Deus. }\end{array}$ \\
\hline DAP 353 & R.G. & M & 35 & Branca & Italiana & & Casado & $\begin{array}{l}\text { Lavrador } \\
\text { / colono }\end{array}$ & Católica & Alfabetizado & $\begin{array}{l}\text { Ribeirão } \\
\text { Preto, SP }\end{array}$ & $\begin{array}{l}\text { 22/01/1910 e } \\
30 / 09 / 1911\end{array}$ & & Cura & Fotografia & $\begin{array}{l}\text { Melancolia an- } \\
\text { siosa. Sifilítico. } \\
\text { Saiu da primei- } \\
\text { ra internaçāo- } \\
\text { curado. Não se } \\
\text { sabe o motivo } \\
\text { do retorno e } \\
\text { permanência } \\
\text { na segunda } \\
\text { internaçāa. } \\
\end{array}$ & Réu & $\begin{array}{l}\text { Carta de próprio punho, } \\
\text { datada de } 12 / 07 / 1912 \text {, } \\
\text { em italiano, destinada } \\
\text { ao diretor. }\end{array}$ \\
\hline DAP 385 & U.B. & M & 32 & Preta & Brasileira & $\begin{array}{l}\text { Rio das } \\
\text { Pedras } \\
\text { ou Pira- } \\
\text { cicaba, } \\
\text { SP }\end{array}$ & Casado & Lavrador & Católica & & $\begin{array}{l}\text { São Pedro, } \\
\text { SP }\end{array}$ & $2 / 2 / 1910$ & $11 / 3 / 1961$ & $\begin{array}{l}\text { Trans- } \\
\text { ferência } \\
\text { para o } \\
\text { Hospital } \\
\text { do Ju- } \\
\text { query }\end{array}$ & Fotografia & $\begin{array}{l}\text { Epilepsia, } \\
\text { parafrenia. } \\
\text { Trinta anos } \\
\text { sem apresentar } \\
\text { ataques epilé- } \\
\text { ticos. Sofria de } \\
\text { pressão alta e } \\
\text { catarata, que } \\
\text { lhe agravaram } \\
\text { a cegueira. } \\
\text { Cirurgia de } \\
\text { hérnia. }\end{array}$ & Réu & \\
\hline DAP 069 & S.S. & M & 26 & Branca & Italiana & $\begin{array}{l}\text { Venosa, } \\
\text { Basilica- } \\
\text { ta, Itália }\end{array}$ & Solteiro & Roceiro & Católica & Alfabetizado & $\begin{array}{l}\text { Rio Claro, } \\
\text { SP }\end{array}$ & $3 / 13 / 1910$ & & & Fotografia & $\begin{array}{l}\text { Síndrome } \\
\text { paranóide. o } \\
\text { interno relata } \\
\text { consciência de } \\
\text { que "perdeu a } \\
\text { sua força mo- } \\
\text { ral", oscilando } \\
\text { entre períodos } \\
\text { de hesitaçāo e } \\
\text { melancolia. }\end{array}$ & \begin{tabular}{|l} 
Réu por \\
homicídio \\
(arts. 294 e \\
62). Crimes \\
e envolvi- \\
mento com \\
"feitiçaria", \\
proposta \\
por um \\
preto com \\
quem divi- \\
diu cela. \\
\end{tabular} & $\begin{array}{l}\text { Pais falecidos. Carta do } \\
\text { interno para uma tia. }\end{array}$ \\
\hline DAP 044 & A.A.S. & M & 22 & Branca & Brasileira & $\begin{array}{l}\text { São José } \\
\text { Paulista, } \\
\text { SP }\end{array}$ & Solteiro & $\begin{array}{l}\text { Lavrador } \\
\text { / roceiro }\end{array}$ & Católica & Analfabeto & $\begin{array}{l}\text { Peniten- } \\
\text { ciária do } \\
\text { Estado, } \\
\text { SP }\end{array}$ & $4 / 1 / 1910$ & $2 / 2 / 1932$ & $\begin{array}{l}\text { Trans- } \\
\text { ferência } \\
\text { para o } \\
\text { Hospital } \\
\text { do Ju- } \\
\text { query }\end{array}$ & Fotografia & $\begin{array}{l}\text { Síndrome } \\
\text { melancólica, } \\
\text { sifilítico }\end{array}$ & $\begin{array}{l}\text { Condenado } \\
\text { por furto. }\end{array}$ & $\begin{array}{l}\text { Faltam informaçōes } \\
\text { como nome da mãe. }\end{array}$ \\
\hline
\end{tabular}




\begin{tabular}{|c|c|c|c|c|c|c|c|c|c|c|c|c|c|c|c|c|c|c|}
\hline 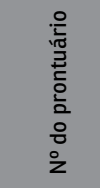 & 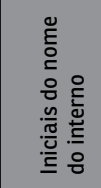 & ঙ્̊ & $\begin{array}{l}\frac{8}{\pi} \\
\frac{\pi}{0}\end{array}$ & ¿̀ & $\begin{array}{l}\frac{\pi}{\pi} \\
\frac{\pi}{\pi} \\
\frac{\pi}{\pi} \\
\frac{0}{0} \\
\frac{\pi}{2}\end{array}$ & 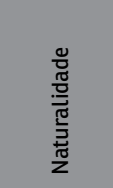 & 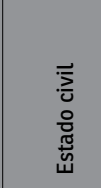 & 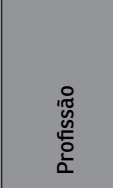 & $\begin{array}{l}\frac{10}{10} \\
\frac{\pi}{\bar{*}} \\
\frac{\pi}{\pi}\end{array}$ & 悹 & 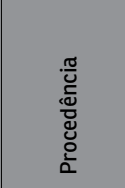 & 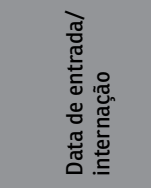 & 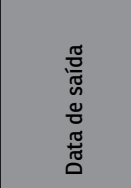 & 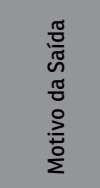 & 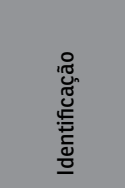 & 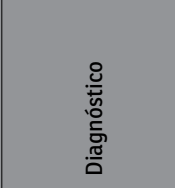 & 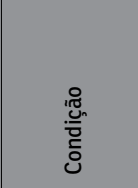 & 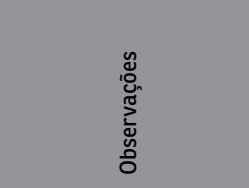 \\
\hline DAP 170 & G.C.Q. & M & 25 & Branca & Brasileira & $\begin{array}{l}\text { Capão } \\
\text { Bonito do } \\
\text { Para- } \\
\text { napane- } \\
\text { ma, SP }\end{array}$ & Solteiro & Roceiro & Católica & & & $4 / 6 / 1910$ & & & Fotografia & $\begin{array}{l}\text { Imbecilidade } \\
\text { com síndrome } \\
\text { paranóide }\end{array}$ & $\begin{array}{l}\text { Condenado } \\
\text { por dar } \\
\text { uma facada } \\
\text { no pescoço } \\
\text { de um } \\
\text { preto }\end{array}$ & $\begin{array}{l}\text { Não há evolução do } \\
\text { caso. }\end{array}$ \\
\hline DAP 040 & A.P.S. & M & 27 & Parda & Brasileira & $\begin{array}{l}\text { Rio Cla- } \\
\text { ro, SP }\end{array}$ & Solteiro & Lavrador & Católica & Analfabeto & $\begin{array}{l}\text { Colônia } \\
\text { Correcio- } \\
\text { nal }\end{array}$ & 4/27/1910 & $11 / 17 / 1934$ & Óbito & Fotografia & $\begin{array}{l}\text { Síndrome } \\
\text { paranóica } \\
\text { com delírio de } \\
\text { perseguição, } \\
\text { sifilítico }\end{array}$ & Réu & $\begin{array}{l}\text { Certidāo de óbito. } \\
\text { Não consta cópia do } \\
\text { processo judicial, nem } \\
\text { o crime. }\end{array}$ \\
\hline DAP 264 & J.S.R. & M & 29 & Parda & Brasileira & $\begin{array}{l}\text { Macaú- } \\
\text { bas, BA }\end{array}$ & Casado & $\begin{array}{l}\text { Empre- } \\
\text { gado }\end{array}$ & & Alfabetizado & $\begin{array}{l}\text { Ribeirão } \\
\text { Preto, SP }\end{array}$ & $5 / 14 / 1910$ & $2 / 2 / 1932$ & $\begin{array}{l}\text { Trans- } \\
\text { ferência } \\
\text { para o } \\
\text { Hospital } \\
\text { do Ju- } \\
\text { query }\end{array}$ & Fotografia & $\begin{array}{l}\text { Demência } \\
\text { paranóide }\end{array}$ & $\begin{array}{l}\text { Condenado } \\
\text { a } 15 \text { anos } \\
\text { de prisão } \\
\text { por homi- } \\
\text { cídio. }\end{array}$ & $\begin{array}{l}\text { Consta ser pardo, mas, } \\
\text { na ficha policial, é } \\
\text { descrito como branco e, } \\
\text { na guia judicial, como } \\
\text { mulato. }\end{array}$ \\
\hline DAP 341 & P.C. & M & 44 & Branca & Italiana & $\begin{array}{l}\text { Veneza, } \\
\text { Itália }\end{array}$ & Casado & $\begin{array}{l}\text { Nego- } \\
\text { ciante }\end{array}$ & Católica & & $\begin{array}{l}\text { São Paulo, } \\
\text { SP }\end{array}$ & $\begin{array}{l}23 / 05 / 1910 \text { e } \\
12 / 03 / 1913\end{array}$ & $10 / 24 / 1913$ & Cura & Fotografia & $\begin{array}{l}\text { Síndrome } \\
\text { paranóide }\end{array}$ & & $\begin{array}{l}4 \text { meses após a } \\
\text { primeira internação, } \\
\text { verificou-se que não } \\
\text { sofria das faculdades } \\
\text { mentais, retornando à } \\
\text { Cadeia Pública. Levado } \\
\text { de volta ao Juquery, } \\
\text { por ter agredido um } \\
\text { carcereiro. }\end{array}$ \\
\hline DAP 030 & A.V. & M & 41 & Branca & Italiana & & & & Católica & & & $7 / 4 / 1910$ & $8 / 5 / 1910$ & Óbito & Fotografia & $\begin{array}{l}\text { Demência pa- } \\
\text { ralítica, forma } \\
\text { angustiosa }\end{array}$ & Réu & $\begin{array}{l}\text { Tem negativismo (não } \\
\text { quis escrever, não se } \\
\text { prestou ao exame do } \\
\text { reflexo pupilar etc). } \\
\text { Não constam nome dos } \\
\text { pais (o interno diz não } \\
\text { se lembrar do passado), } \\
\text { nem cópia do processo } \\
\text { judicial. Faleceu de } \\
\text { "marasmo". }\end{array}$ \\
\hline DAP 012 & A.F.X. & M & 29 & Parda & Brasileira & $\begin{array}{l}\text { Barra } \\
\text { Mansa, } \\
\text { RJ }\end{array}$ & Viúvo & $\begin{array}{l}\text { Carpin- } \\
\text { teiro }\end{array}$ & Católica & Analfabeto & $\begin{array}{l}\text { Bananal, } \\
\text { SP }\end{array}$ & $8 / 25 / 1910$ & $6 / 3 / 1933$ & Óbito & Fotografia & $\begin{array}{l}\text { Demência pre- } \\
\text { coce catatônica }\end{array}$ & \begin{tabular}{|l} 
Réu (art. \\
294 do \\
Código \\
Penal). \\
Assassinato \\
a golpes \\
de foice e \\
agressão.
\end{tabular} & $\begin{array}{l}\text { Certidão de óbito por } \\
\text { "congestão pulmonar". }\end{array}$ \\
\hline
\end{tabular}




\begin{tabular}{|c|c|c|c|c|c|c|c|c|c|c|c|c|c|c|c|c|c|c|}
\hline 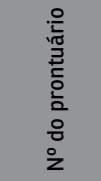 & 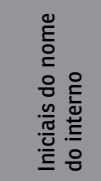 & ঙ̊̀. & $\begin{array}{l}\text { 苋 } \\
\text { 五 }\end{array}$ & ¿̀ & $\begin{array}{l}\frac{\pi}{\pi} \\
\frac{\pi}{\pi} \\
\stackrel{\pi}{\pi} \\
\frac{0}{0} \\
\frac{\pi}{2} \\
\frac{\pi}{2}\end{array}$ & 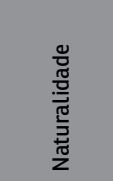 & 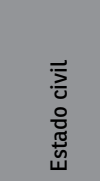 & 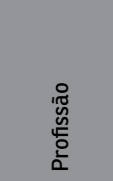 & $\begin{array}{l}\frac{\pi}{\pi} \\
\frac{\pi}{\bar{m}} \\
\frac{\pi}{\pi} \\
\frac{\pi}{\pi}\end{array}$ & 㝕 & 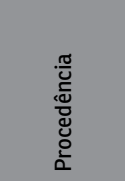 & 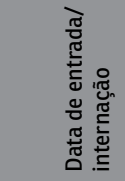 & $\begin{array}{l}\frac{\pi}{0} \\
\frac{0}{\pi} \\
0 \\
0 \\
\frac{\pi}{\pi} \\
0\end{array}$ & $\begin{array}{l}\frac{\pi}{0} \\
\frac{0}{0} \\
0 \\
\frac{\pi}{0} \\
0 \\
\stackrel{0}{0} \\
\sum\end{array}$ & 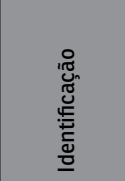 & 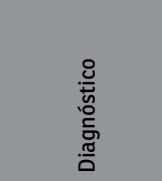 & 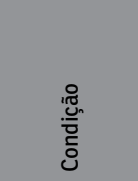 & 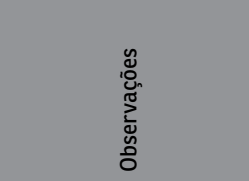 \\
\hline DAP 164 & F.P. & M & 45 & Branca & Italiana & $\begin{array}{l}\text { Cam- } \\
\text { panha, } \\
\text { Nápoles, } \\
\text { Itália }\end{array}$ & Solteiro & Cocheiro & Católica & Alfabetizado & $\begin{array}{l}\text { Cadeia da } \\
\text { Capital, } \\
\text { SP }\end{array}$ & 9/30/1910 & $8 / 1 / 1947$ & Óbito & $\begin{array}{l}\text { Fotografia } \\
\text { e digitais }\end{array}$ & $\begin{array}{l}\text { Síndrome } \\
\text { paranóide, } \\
\text { parafrenia }\end{array}$ & $\begin{array}{l}\text { Condenado } \\
\text { a um ano } \\
\text { de prisão } \\
\text { (art. 303), } \\
\text { por atirar } \\
\text { em um } \\
\text { afilhado. }\end{array}$ & $\begin{array}{l}\text { Receitas de remédios. } \\
\text { Fotos no momento } \\
\text { da entrada e saída } \\
\text { (cadáver). Faleceu por } \\
\text { gangrena no escroto. }\end{array}$ \\
\hline DAP 178 & H.N. & M & 40 & Preta & Brasileira & $\begin{array}{l}\text { Campi- } \\
\text { nas, SP }\end{array}$ & Casado & Roceiro & Católica & Alfabetizado & $\begin{array}{l}\text { Cadeia } \\
\text { Pública de } \\
\text { São Paulo }\end{array}$ & $12 / 18 / 1910$ & $1 / 28 / 1913$ & Óbito & Fotografia & $\begin{array}{l}\text { Síndrome } \\
\text { paranóide }\end{array}$ & Réu & $\begin{array}{l}\text { Consta ser católico, } \\
\text { mas foi protestante. } \\
\text { Tentou fugir. Carta } \\
\text { redigida pelo interno, } \\
\text { na qual pede ao Dr. G. } \\
\text { paciência, até se curar. } \\
\text { Preso diversas vezes } \\
\text { por bebedeira, vaga- } \\
\text { bundagem e afanagem } \\
\text { de notas falsas. }\end{array}$ \\
\hline DAP 343 & P.M. & M & 33 & Branca & Italiana & & Casado & Ferreiro & & & $\begin{array}{l}\text { São Paulo, } \\
\text { SP }\end{array}$ & $12 / 20 / 1910$ & 3/21/1911 & Óbito & Fotografia & Paralisia geral & & $\begin{array}{l}\text { Faleceu de hemorragia } \\
\text { cerebral. }\end{array}$ \\
\hline DAP 342 & P.F. & M & 37 & Branca & Brasileira & & Solteiro & Oleiro & Católica & Alfabetizado & $\begin{array}{l}\text { São Paulo, } \\
\text { SP }\end{array}$ & 1/6/1911 & $3 / 17 / 1943$ & $\begin{array}{l}\text { Trans- } \\
\text { ferência } \\
\text { para o } \\
\text { Hospital } \\
\text { do Ju- } \\
\text { query }\end{array}$ & $\begin{array}{l}\text { Fotografia } \\
\text { e assina- } \\
\text { tura }\end{array}$ & $\begin{array}{l}\text { Síndrome } \\
\text { paranóide, } \\
\text { parafrenia }\end{array}$ & $\begin{array}{l}\text { Réu (art. } \\
294 \text { do } \\
\text { Código } \\
\text { Penal, } \$ 2^{\circ} \\
\text { do Código } \\
\text { Penal). } \\
\text { Condenado } \\
\text { a } 10 \text { anos e } \\
6 \text { meses de } \\
\text { prisão em } \\
\text { penitenciá- } \\
\text { ria comum. }\end{array}$ & $\begin{array}{l}\text { Cumpriu parte da pena, } \\
\text { tendo enlouquecido na } \\
\text { penitenciária. Constam } \\
\text { diversos nomes, grau } \\
\text { de parentesco e endere- } \\
\text { ço de cinco familiares. }\end{array}$ \\
\hline DAP 344 & P.P.M.S. & M & 26 & Parda & Brasileira & & Solteiro & Roceiro & Católica & & Una, SP & $1 / 20 / 1911$ & $1 / 9 / 1932$ & Óbito & $\begin{array}{l}\text { Fotografia } \\
\text { e assina- } \\
\text { tura }\end{array}$ & $\begin{array}{l}\text { Mal epilético, } \\
\text { epilepsia } \\
\text { nervosa }\end{array}$ & $\begin{array}{l}\text { Acusado do } \\
\text { homicídio } \\
\text { de um } \\
\text { amigo }\end{array}$ & $\begin{array}{l}\text { O delegado de políicia } \\
\text { diz ser mulato, pobre e } \\
\text { transferido sem ates- } \\
\text { tado médico. Não se } \\
\text { lembrava do ocorrido. } \\
\text { Segundo lhe contaram, } \\
\text { ele assassinou um } \\
\text { companheiro de jogo. }\end{array}$ \\
\hline
\end{tabular}




\begin{tabular}{|c|c|c|c|c|c|c|c|c|c|c|c|c|c|c|c|c|c|c|}
\hline 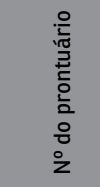 & 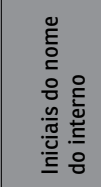 & §̊̀. & 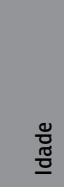 & ¿̀ & 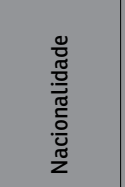 & 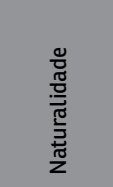 & 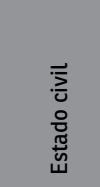 & 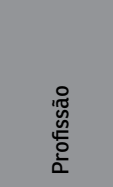 & $\frac{10}{\square}$ & 空 & 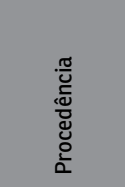 & 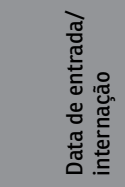 & $\begin{array}{l}\frac{\pi}{0} \\
\frac{\pi}{\pi} \\
0 \\
\frac{\pi}{\pi} \\
\frac{\pi}{0}\end{array}$ & $\begin{array}{l}\frac{\pi}{0} \\
\frac{0}{5} \\
\frac{\pi}{0} \\
0 \\
\stackrel{0}{0} \\
\frac{0}{2}\end{array}$ & 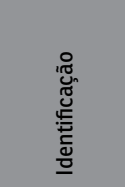 & 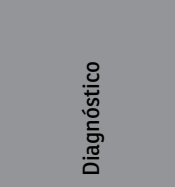 & 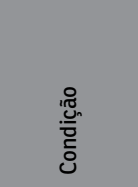 & 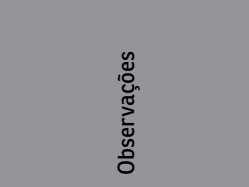 \\
\hline DAP 227 & J.S.E.S. & $M$ & 45 & Branca & Brasileira & $\begin{array}{l}\text { Capão } \\
\text { Bonito, } \\
\text { SP }\end{array}$ & Casado & $\begin{array}{l}\text { Carpin- } \\
\text { teiro }\end{array}$ & Católica & & $\begin{array}{l}\text { Capão } \\
\text { Bonito, SP }\end{array}$ & 3/12/1911 & & & Fotografia & Delírio & $\begin{array}{l}\text { Condenado } \\
\text { a } 10 \text { anos } \\
\text { de prisão } \\
\text { por homi- } \\
\text { cídio. }\end{array}$ & $\begin{array}{l}0 \text { interno tem nível } \\
\text { intelectual pouco } \\
\text { elevado. }\end{array}$ \\
\hline DAP 119 & D.F. & $M$ & 36 & Branca & Italiana & $\begin{array}{l}\text { San } \\
\text { Severa } \\
\text { de Pugli, } \\
\text { Itália }\end{array}$ & Casado & Colono & Católica & & & 3/17/1911 & & & $\begin{array}{l}\text { Fotografia, } \\
\text { exames } \\
\text { (urina, } \\
\text { liquido } \\
\text { cefalorra- } \\
\text { quidiano e } \\
\text { Wasser- } \\
\text { mann) }\end{array}$ & Sifilítico & $\begin{array}{l}\text { Condenado } \\
\text { a } 10 \text { anos } \\
\text { e meio de } \\
\text { prisão por } \\
\text { homicídio, } \\
\text { tendo } \\
\text { cumprido } \\
26 \text { meses } \\
\text { até ser } \\
\text { transferido } \\
\text { para o } \\
\text { Juquery. }\end{array}$ & $\begin{array}{l}\text { Alega que cometeu o } \\
\text { homicídio em ocasiāo } \\
\text { em que os dois estavam } \\
\text { embriagados. }\end{array}$ \\
\hline DAP 116 & c.U. & M & 40 & Branca & Italiana & Itália & Casado & Ignorada & Ignorada & & $\begin{array}{l}\text { São Paulo, } \\
\text { SP }\end{array}$ & 3/17/1911 & & & $\begin{array}{l}\text { Fotografia } \\
\text { e radio- } \\
\text { grafia do } \\
\text { pulmão }\end{array}$ & $\begin{array}{l}\text { Demência } \\
\text { aguda curável, } \\
\text { estupidez vesâ-- } \\
\text { nica, síndrome } \\
\text { catatônica }\end{array}$ & & $\begin{array}{l}\text { Durante parte da in- } \\
\text { ternaçāo, mantinha-se } \\
\text { em estado de apatia. } \\
\text { Começou a andar e } \\
\text { alimentar-se bem e, em } \\
\text { 1912, estava comple- } \\
\text { tamente curado. Tra- } \\
\text { tamento com banhos } \\
\text { quentes e alimentação } \\
\text { forçada. }\end{array}$ \\
\hline DAP 111 & c.c.s. & M & 22 & Parda & Brasileira & $\begin{array}{l}\text { Jardinó- } \\
\text { polis, SP }\end{array}$ & Solteiro & Roceiro & Católica & & $\begin{array}{l}\text { Orlândia, } \\
\text { SPP }\end{array}$ & 4/5/1911 & $2 / 3 / 1932$ & $\begin{array}{l}\text { Trans- } \\
\text { ferência } \\
\text { para o } \\
\text { Hospital } \\
\text { do Ju- } \\
\text { query }\end{array}$ & Fotografia & $\begin{array}{l}\text { Epilepsia, síflis } \\
\text { e alcoólatra }\end{array}$ & $\begin{array}{l}\text { Réu (art. } \\
294 \text { do } \\
\text { Código } \\
\text { Penal, } \$ 2^{\circ} \\
\text { do Código } \\
\text { Penal). } \\
\text { Acusado } \\
\text { de matar a } \\
\text { mãe a faca- } \\
\text { das, não } \\
\text { se lembra } \\
\text { de ter } \\
\text { cometido o } \\
\text { crime. }\end{array}$ & $\begin{array}{l}\text { O delegado de Orlândia } \\
\text { o enviou ao Juquery, } \\
\text { por não haver médicos } \\
\text { especializados na } \\
\text { cidade, esperando diag- } \\
\text { nóstico do acusado. Em } \\
\text { 193l, o juiz da cidade } \\
\text { diz não poder dar desti- } \\
\text { no ao sentenciado, por } \\
\text { falta de informaçōes do } \\
\text { Manicômio Judiciário. }\end{array}$ \\
\hline
\end{tabular}




\begin{tabular}{|c|c|c|c|c|c|c|c|c|c|c|c|c|c|c|c|c|c|c|}
\hline 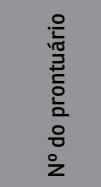 & 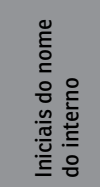 & 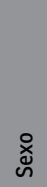 & $\begin{array}{l}\text { 苋 } \\
\text { 元 }\end{array}$ & ¿̀ & $\begin{array}{l}\frac{\pi}{\pi} \\
\frac{\pi}{0} \\
\frac{0}{\pi} \\
\frac{0}{0} \\
\frac{\pi}{2} \\
\frac{\pi}{2}\end{array}$ & 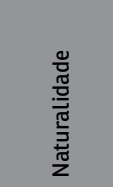 & 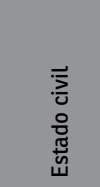 & 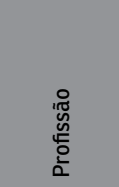 & : & 㝕 & 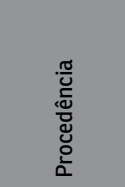 & 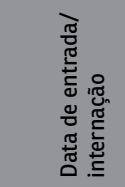 & 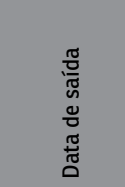 & $\begin{array}{l}\frac{\pi}{0} \\
\frac{0}{0} \\
0 \\
\frac{\pi}{0} \\
0 \\
\stackrel{0}{0} \\
\sum\end{array}$ & 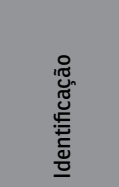 & 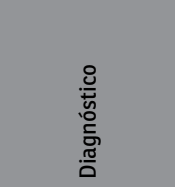 & 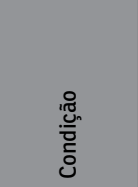 & 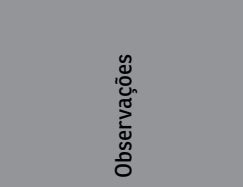 \\
\hline DAP 255 & J.J.N. & M & 35 & Preta & Brasileira & $\begin{array}{l}\text { Santa } \\
\text { Catarina, } \\
\text { MG }\end{array}$ & Casado & $\begin{array}{l}\text { Cama- } \\
\text { rada }\end{array}$ & Católica & & $\begin{array}{l}\text { São João } \\
\text { da Boa } \\
\text { Vista, SP }\end{array}$ & 6/11/1911 & 7/23/1913 & Óbito & $\begin{array}{l}\text { Fotografía } \\
\text { e radio- } \\
\text { grafia do } \\
\text { pulmão }\end{array}$ & $\begin{array}{l}\text { Irritabilidade, } \\
\text { desconfiança } \\
\text { e alucinaçōes } \\
\text { auditivas }\end{array}$ & $\begin{array}{l}\text { Tentativa } \\
\text { de assas- } \\
\text { sinato de } \\
\text { seu patrão, } \\
\text { após discu- } \\
\text { tirem por } \\
\text { acordo não } \\
\text { cumprido, } \\
\text { o que } \\
\text { resultou } \\
\text { em troca } \\
\text { de tiros }\end{array}$ & $\begin{array}{l}\text { Após ser preso, alegou } \\
\text { ser perseguido dentro } \\
\text { da prisão, o que o levou } \\
\text { ao manicômio. }\end{array}$ \\
\hline DAP 067 & A.P. & M & 44 & Branca & Brasileira & & Casado & & Católica & Alfabetizado & $\begin{array}{l}\text { Limeira, } \\
\text { SP }\end{array}$ & 6/23/1911 & & & $\begin{array}{l}\text { Fotografia } \\
\text { escrita }\end{array}$ & $\begin{array}{l}\text { Melancolia } \\
\text { ansiosa, } \\
\text { consequente } \\
\text { do abuso de } \\
\text { álcool }\end{array}$ & $\begin{array}{l}\text { Matou a } \\
\text { esposa a } \\
\text { pancadas, } \\
\text { com um } \\
\text { cano de } \\
\text { ferro, após } \\
\text { abuso } \\
\text { alcoólico }\end{array}$ & $\begin{array}{l}\text { O estado de delírio } \\
\text { desapareceu em } 1905 \text {. } \\
\text { Envolvido com jogos. } \\
\text { Sempre esteve bem } \\
\text { empregado. Delira bas- } \\
\text { tante, durante muito } \\
\text { tempo. Fuma desde os } \\
\text { oito anos. }\end{array}$ \\
\hline DAP 354 & S.L. & M & 28 & Branca & Italiana & $\begin{array}{l}\text { Catano, } \\
\text { Itália }\end{array}$ & Casado & $\begin{array}{l}\text { Cama- } \\
\text { rada }\end{array}$ & Católica & & $\begin{array}{l}\text { Pindamo- } \\
\text {-nhanga- } \\
\text { ba, SP }\end{array}$ & 7/3/1911 & & & Fotografia & $\begin{array}{l}\text { Delírio de } \\
\text { perseguiçāo }\end{array}$ & $\begin{array}{l}\text { Conde- } \\
\text { nado a } 6 \\
\text { anos por } \\
\text { homicídio. } \\
\text { Assassinou } \\
\text { um compa- } \\
\text { nheiro, mas } \\
\text { não explica } \\
\text { a razão }\end{array}$ & $\begin{array}{l}\text { Alega não existir Jus- } \\
\text { tiça no Brasil, dizendo } \\
\text { que irá fazer uma } \\
\text { reclamacaáo ao governo } \\
\text { da Itália. Afirma ter } \\
\text { um corpo divino e ser } \\
\text { perseguido devido } \\
\text { à sua ligaçāo com a } \\
\text { divindade. }\end{array}$ \\
\hline DAP 394 & V.R. & M & 39 & Branca & Italiana & $\begin{array}{l}\text { Catanza- } \\
\text { ro, Itália }\end{array}$ & Solteiro & Tintureiro & Católica & & Franca, SP & 7/18/1911 & $1 / 30 / 1939$ & Óbito & $\begin{array}{l}\text { Fotografía } \\
\text { e radio- } \\
\text { grafia do } \\
\text { pulmão }\end{array}$ & $\begin{array}{l}\text { Depressāo, } \\
\text { psicose aluci- } \\
\text { natória crônica, } \\
\text { em que há } \\
\text { rebaixamento } \\
\text { mental }\end{array}$ & $\begin{array}{l}\text { Acusado de } \\
\text { homicídio, } \\
\text { a golpes } \\
\text { de faca de } \\
\text { sapateiro. } \\
\text { Agrediu } \\
\text { uma } \\
\text { família, } \\
\text { invadindo } \\
\text { sua casa }\end{array}$ & $\begin{array}{l}\text { Tinha uma irmã em um } \\
\text { hospício na Itália. Vivia } \\
\text { de forma precária, } \\
\text { sem preocupaçōes em } \\
\text { acumular fortuna e } \\
\text { bem-estar.Teve câncer. } \\
\text { Não desejava voltar } \\
\text { ao meio social nem se } \\
\text { relacionava com outros } \\
\text { internos. Morreu de } \\
\text { tuberculose pulmonar., }\end{array}$ \\
\hline
\end{tabular}




\begin{tabular}{|c|c|c|c|c|c|c|c|c|c|c|c|c|c|c|c|c|c|c|}
\hline 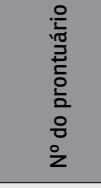 & 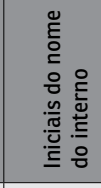 & ॐัे & $\begin{array}{l}\frac{8}{\tilde{\sigma}} \\
\text { 吾 }\end{array}$ & ò & 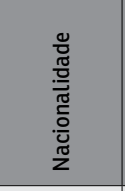 & 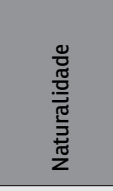 & 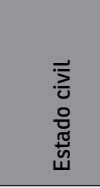 & 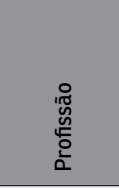 & 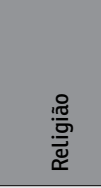 & 胥 & 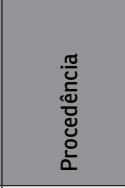 & 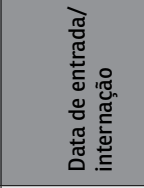 & 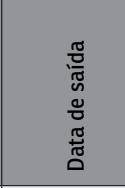 & $\begin{array}{l}\frac{\pi}{0} \\
\text { N } \\
\frac{\pi}{0} \\
0 \\
\frac{0}{0} \\
\frac{0}{2}\end{array}$ & 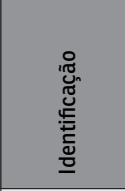 & 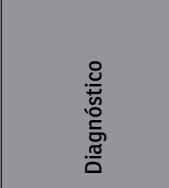 & 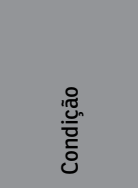 & 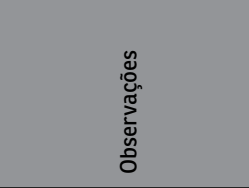 \\
\hline DAP 247 & J.F. & $M$ & 35 & Branca & Italiana & $\begin{array}{l}\text { Freuza, } \\
\text { Itália }\end{array}$ & Viúvo & $\begin{array}{l}\text { Nego- } \\
\text { ciante, } \\
\text { colono }\end{array}$ & Católica & & $\begin{array}{l}\text { Piracica- } \\
\text { ba, SP }\end{array}$ & 9/26/1911 & 2/24/1912 & & Fotografia & $\begin{array}{l}\text { Moléstia } \\
\text { mental, de- } \\
\text { pressão moral, } \\
\text { hipertrofia } \\
\text { da glândula } \\
\text { tireóidica e } \\
\text { epilepsia }\end{array}$ & $\begin{array}{l}\text { Matou sua } \\
\text { mulher, } \\
\text { porém não } \\
\text { se recorda } \\
\text { do motivo }\end{array}$ & $\begin{array}{l}\text { Carta do juiz da } \\
\text { Comarca de Piracicaba } \\
\text { indagando sobre as } \\
\text { condiçōes do interno, } \\
\text { com respostas da admi- } \\
\text { nistração do Hospício } \\
\text { do Juquery. }\end{array}$ \\
\hline DAP 045 & A.A.N. & $M$ & 30 & Branca & Brasileira & $\begin{array}{l}\text { Franca, } \\
\text { SP }\end{array}$ & Solteiro & Advogado & Católica & & Franca, SP & $11 / 9 / 1911$ & 4/21/1914 & & Fotografia & Alcoolismo & & \\
\hline DAP 323 & O.C.N. & $M$ & 36 & Preta & Brasileira & $\begin{array}{l}\text { Rio Cla- } \\
\text { ro, SP }\end{array}$ & Casado & $\begin{array}{l}\text { Trabalha- } \\
\text { dor }\end{array}$ & Católica & & $\begin{array}{l}\text { São Paulo, } \\
\text { SP }\end{array}$ & $11 / 20 / 1911$ & 7/16/1913 & Óbito & $\begin{array}{l}\text { fotografia } \\
\text { e texto } \\
\text { pessoal } \\
\text { (ilegivel) }\end{array}$ & $\begin{array}{l}\text { Demência } \\
\text { paralítica }\end{array}$ & $\begin{array}{l}\text { Não foi } \\
\text { possível } \\
\text { identificar } \\
\text { o crime }\end{array}$ & $\begin{array}{l}\text { Abuso de álcool e } \\
\text { tabaco. }\end{array}$ \\
\hline DAP 303 & M.A. & $M$ & 35 & Branca & Italiana & $\begin{array}{l}\text { Potenza, } \\
\text { Itália }\end{array}$ & Casado & $\begin{array}{l}\text { Nego- } \\
\text { ciante }\end{array}$ & Católica & Alfabetizado & $\begin{array}{l}\text { São Paulo, } \\
\text { SP }\end{array}$ & $\begin{array}{l}\text { 17/12/1910 e } \\
\text { 20/11/1911 }\end{array}$ & $4 / 28 / 1912$ & Cura & $\begin{array}{l}\text { Fotogra- } \\
\text { fia, carta, } \\
\text { assi- } \\
\text { natura, } \\
\text { matéria } \\
\text { de jornal }\end{array}$ & $\begin{array}{l}\text { Degeneração } \\
\text { moral. Sofre } \\
\text { das faculdades } \\
\text { mentais }\end{array}$ & $\begin{array}{l}\text { Preso, } \\
\text { aos 20 } \\
\text { anos, pela } \\
\text { primeira } \\
\text { vez, por } \\
\text { tentativa de } \\
\text { assassina- } \\
\text { do de sua } \\
\text { esposa }\end{array}$ & $\begin{array}{l}\text { Histórico familiar. Re- } \\
\text { lato de agressão contra } \\
\text { M. A. pelo interno } \\
\text { durante o cumprimento } \\
\text { da pena. Relato de sua } \\
\text { história de vida. Re- } \\
\text { cortes de jornais sobre } \\
\text { o crime, informaçōes } \\
\text { sobre clubes, fábricas, } \\
\text { comércios e ruas de } \\
\text { São Paulo. }\end{array}$ \\
\hline DAP 096 & B.R. & M & 20 & Branca & Brasileira & $\begin{array}{l}\text { Parnaíba, } \\
\text { PI }\end{array}$ & Solteiro & $\begin{array}{l}\text { Cama- } \\
\text { rada }\end{array}$ & Católica & & $\begin{array}{l}\text { Cadeia } \\
\text { Pública da } \\
\text { Capital, } \\
\text { SP, SP } \\
\end{array}$ & 3/5/1912 & $5 / 10 / 1912$ & Cura & Fotografia & $\begin{array}{l}\text { Imbecil e } \\
\text { impulsivo, } \\
\text { sifilítico }\end{array}$ & $\begin{array}{l}\text { Condenado } \\
\text { por homi- } \\
\text { cídio }\end{array}$ & \\
\hline DAP 274 & J.J.J.N. & M & 24 & Preta & Brasileira & & Solteiro & & Espírita & & $\begin{array}{l}\text { Taubaté, } \\
\text { SP }\end{array}$ & $3 / 31 / 1912$ & $8 / 2 / 1912$ & Cura & Fotografia & $\begin{array}{l}\text { Degenerado } \\
\text { e alcoolista, } \\
\text { sifilítico }\end{array}$ & $\begin{array}{l}\text { Não há } \\
\text { informação } \\
\text { sobre o } \\
\text { crime }\end{array}$ & \\
\hline DAP 372 & S.C. & M & 50 & Parda & Brasileira & & & & & & Brotas, SP & $5 / 11 / 1912$ & & & Fotografia & $\begin{array}{l}\text { Demência pre- } \\
\text { coce paranóide }\end{array}$ & $\begin{array}{l}\text { Não há } \\
\text { informação } \\
\text { sobre o } \\
\text { crime }\end{array}$ & \\
\hline DAP 058 & A.G. & M & 49 & Branca & $\begin{array}{l}\text { Espa- } \\
\text { nhola }\end{array}$ & Espanha & Casado & $\begin{array}{l}\text { Cozinhei- } \\
\text { ro }\end{array}$ & Católica & Analfabeto & & 6/13/1912 & & & Fotografia & $\begin{array}{l}\text { Epilepsia, } \\
\text { crise delirante } \\
\text { alcoólica }\end{array}$ & Réu & $\begin{array}{l}\text { Esteve internado no } \\
\text { Hospício Nacional de } \\
\text { Alienados do Rio de } \\
\text { Janeiro e no Juquery. } \\
\text { Recortes de jornais com } \\
\text { notícias dos crimes. } \\
\text { Maltratava sua mulher } \\
\text { e tentou matá-la "por } \\
\text { vezes com um macha- } \\
\text { dinho". }\end{array}$ \\
\hline
\end{tabular}




\begin{tabular}{|c|c|c|c|c|c|c|c|c|c|c|c|c|c|c|c|c|c|c|}
\hline 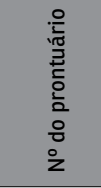 & 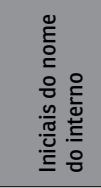 & ֻั̊ & $\begin{array}{l}\text { 苋 } \\
\text { 五 }\end{array}$ & ¿̀ & $\begin{array}{l}\frac{8}{\pi} \\
\frac{\pi}{0} \\
\frac{0}{\pi} \\
\frac{5}{0} \\
\frac{\pi}{2}\end{array}$ & $\begin{array}{l}\frac{8}{\pi} \\
\frac{\pi}{0} \\
\frac{\pi}{\pi} \\
\frac{\pi}{2} \\
\frac{\pi}{2}\end{array}$ & 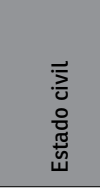 & 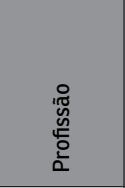 & $\frac{10}{\frac{10}{\pi}}$ & 突 & 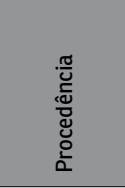 & 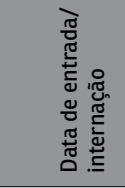 & 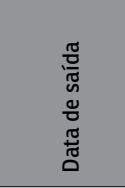 & 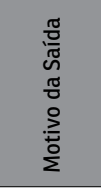 & 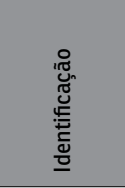 & 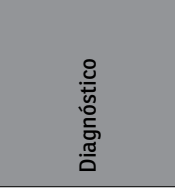 & 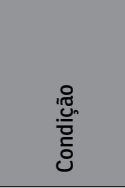 & 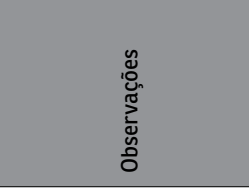 \\
\hline DAP 025 & A.B. & M & 24 & Branca & $\begin{array}{l}\text { Espa- } \\
\text { nhola }\end{array}$ & Espanha & Solteiro & Lavrador & Católica & Analfabeto & $\begin{array}{l}\text { Bragança, } \\
\text { SP }\end{array}$ & 8/6/1912 & 4/16/1936 & $\begin{array}{l}\text { Trans- } \\
\text { ferência } \\
\text { para o } \\
\text { Hospital } \\
\text { do Ju- } \\
\text { query }\end{array}$ & Fotografia & $\begin{array}{l}\text { Psicose } \\
\text { maníaco-de- } \\
\text { pressiva, surtos } \\
\text { delirantes. }\end{array}$ & $\begin{array}{l}\text { Condenado } \\
\text { por homi- } \\
\text { cídio }\end{array}$ & $\begin{array}{l}\text { Cópia do processo } \\
\text { judicial, no qual consta } \\
\text { pedido da irmă sobre as } \\
\text { condiçōes de saúde. Na } \\
\text { guia de exame odonto- } \\
\text { lógico, a nacionalidade } \\
\text { é brasileira. Na necrop- } \\
\text { sia, constam } 6 \text { possíveis } \\
\text { causas mortis }\end{array}$ \\
\hline DAP 155 & F.B.P. & M & 27 & Parda & Brasileira & $\begin{array}{l}\text { Cambuí, } \\
\text { MG }\end{array}$ & Solteiro & $\begin{array}{l}\text { Trabalha- } \\
\text { dor }\end{array}$ & $\begin{array}{l}\text { Protes- } \\
\text { tante }\end{array}$ & & $\begin{array}{l}\text { Bragança, } \\
\text { SP }\end{array}$ & 8/6/1912 & 2/5/1957 & Óbito & $\begin{array}{l}\text { Fotografia } \\
\text { e digitais }\end{array}$ & $\begin{array}{l}\text { Epilepsia lar- } \\
\text { vada, demência } \\
\text { precoce }\end{array}$ & $\begin{array}{l}\text { Réu por } \\
\text { homicídio }\end{array}$ & $\begin{array}{l}\text { Possui boa conduta e } \\
\text { trabalhou em diversos } \\
\text { lugares. Antes da } \\
\text { criação do manicômio, } \\
\text { "o interno encontra- } \\
\text { va-se hospitalizado na } \\
\text { primeira colônia e rea- } \\
\text { lizava servico externo". } \\
\text { Em 1954, direção do } \\
\text { manicômio contraindi- } \\
\text { ca a laborterapia. }\end{array}$ \\
\hline DAP 374 & S.L. & M & 37 & Branca & Italiana & & Solteiro & $\begin{array}{l}\text { Trabalha- } \\
\text { dor }\end{array}$ & Católica & & $\begin{array}{l}\text { Botucatu, } \\
\text { SP }\end{array}$ & 9/12/1912 & 3/3/1913 & Óbito & Fotografia & $\begin{array}{l}\text { Excitação ma- } \\
\text { níaca, sifilítico }\end{array}$ & & \\
\hline DAP 234 & J.B.C. & M & 48 & branca & Brasileira & & Casado & $\begin{array}{l}\text { Trabalha- } \\
\text { dor }\end{array}$ & Católica & Alfabetizado & $\begin{array}{l}\text { Taubaté, } \\
\text { SP }\end{array}$ & $10 / 11 / 1912$ & & & Fotografia & $\begin{array}{l}\text { Loucura maní- } \\
\text { aco-depressiva, } \\
\text { sifilítico }\end{array}$ & Réu & $\begin{array}{l}\text { Vivia bem com a espo- } \\
\text { sa, mas se divorciaram } \\
\text { devido ao estado de } \\
\text { alienação mental do } \\
\text { marido. "Diz que a mo- } \\
\text { léstia atual começou } \\
\text { (...) após a picada de } \\
\text { uma cobra". }\end{array}$ \\
\hline DAP 347 & P.R. & M & 47 & Branca & Brasileira & $\begin{array}{l}\text { Limeira, } \\
\text { SP }\end{array}$ & Casado & $\begin{array}{l}\text { Trabalha- } \\
\text { dor }\end{array}$ & Católica & & $\begin{array}{l}\text { Limeira, } \\
\text { SP }\end{array}$ & $11 / 27 / 1912$ & & & Fotografia & $\begin{array}{l}\text { Degeneração } \\
\text { psíquica, } \\
\text { demência alco- } \\
\text { ólica, sifilííico }\end{array}$ & Réu & \\
\hline DAP 046 & A.B. & M & 33 & Branca & Brasileira & $\begin{array}{l}\text { São José } \\
\text { dos Cam- } \\
\text { pos, SP }\end{array}$ & Solteiro & $\begin{array}{l}\text { Trabalha- } \\
\text { dor }\end{array}$ & Católica & Alfabetizado & $\begin{array}{l}\text { Limeira, } \\
\text { SP }\end{array}$ & $11 / 29 / 1912$ & & & Fotografia & $\begin{array}{l}\text { Fraco de espíri- } \\
\text { to, alcoólara }\end{array}$ & $\begin{array}{l}\text { Agressão } \\
\text { ao patrão }\end{array}$ & $\begin{array}{l}\text { Na capa do prontuário, } \\
\text { o estado civil é "soltei- } \\
\text { ro", mas, na anamnese, } \\
\text { diz ter sido casado } \\
\text { por pouco tempo, } \\
\text { pois ela "era de maus } \\
\text { costumes". }\end{array}$ \\
\hline
\end{tabular}




\begin{tabular}{|c|c|c|c|c|c|c|c|c|c|c|c|c|c|c|c|c|c|c|}
\hline 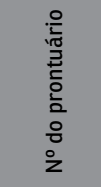 & 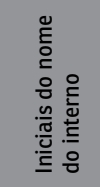 & 离 & $\begin{array}{l}\text { 营 } \\
\text { 元 }\end{array}$ & ¿̀ & $\begin{array}{l}\frac{\pi}{\pi} \\
\frac{\pi}{0} \\
\frac{\pi}{\pi} \\
\frac{0}{0} \\
\frac{\pi}{2} \\
\frac{\pi}{2}\end{array}$ & 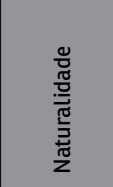 & 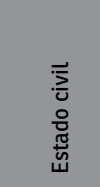 & 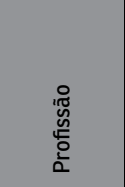 & : & 悹 & 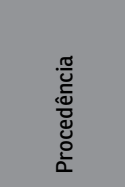 & 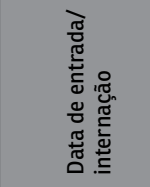 & 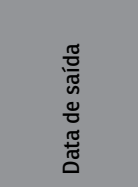 & 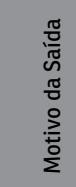 & 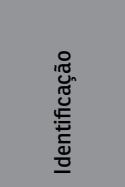 & 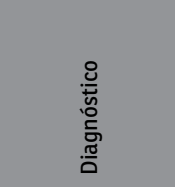 & 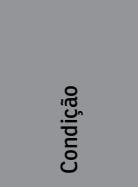 & 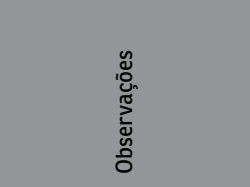 \\
\hline DAP 239 & J.C.N. & M & 26 & Branca & Brasileira & $\begin{array}{l}\text { Limeira, } \\
\text { SP }\end{array}$ & Casado & $\begin{array}{l}\text { Empre- } \\
\text { gado } \\
\text { público }\end{array}$ & Católica & & $\begin{array}{l}\text { Limeira, } \\
\text { SP }\end{array}$ & $12 / 8 / 1912$ & & & Fotografia & $\begin{array}{l}\text { Demência } \\
\text { precoce, sob a } \\
\text { forma paranói- } \\
\text { de, sifilítico }\end{array}$ & $\begin{array}{l}\text { Condenado } \\
\text { por homi- } \\
\text { cídio }\end{array}$ & $\begin{array}{l}\text { Carta ao Franco da } \\
\text { Rocha informando que } \\
\text { o interno possuía síflis } \\
\text { havia } 5 \text { anos e procurou } \\
\text { tratamento recorrendo } \\
\text { a "conselhos de curan- } \\
\text { deiros e "feitiçarias". } \\
\text { Constam cartas do } \\
\text { interno, uma delas } \\
\text { relatando seu próprio } \\
\text { estado. }\end{array}$ \\
\hline DAP 072 & A.T. & M & 24 & Branca & Italiana & $\begin{array}{l}\text { Rovigo, } \\
\text { Itália }\end{array}$ & Solteiro & $\begin{array}{l}\text { Trabalha- } \\
\text { dor }\end{array}$ & Católica & & $\begin{array}{l}\text { Santa Rita } \\
\text { do Passo } \\
\text { Quatro, } \\
\text { SP }\end{array}$ & $12 / 17 / 1912$ & $1 / 29 / 1913$ & Cura & Fotografia & $\begin{array}{l}\text { Alcoolismo } \\
\text { agudo, sifilítico }\end{array}$ & $\begin{array}{l}\text { Réu, crime } \\
\text { não infor- } \\
\text { mado }\end{array}$ & $\begin{array}{l}\text { Não foi observada } \\
\text { nenhuma "moléstia } \\
\text { mental". }\end{array}$ \\
\hline DAP 134 & E.P.E. & M & 48 & Branca & Brasileira & $\begin{array}{l}\text { Jaguaria- } \\
\text { iva, PR }\end{array}$ & Viúvo & $\begin{array}{l}\text { Trabalha- } \\
\text { dor }\end{array}$ & Católica & Alfabetizado & Tatuí, SP & $12 / 19 / 1912$ & 2/4/1913 & Óbito & Fotografia & $\begin{array}{l}\text { Demência para- } \\
\text { Lítica, sifflítico }\end{array}$ & $\begin{array}{l}\text { Réu, crime } \\
\text { não infor- } \\
\text { mado }\end{array}$ & $\begin{array}{l}\text { Informou sobre seus } \\
\text { familiares e deu infor- } \\
\text { maçōes pessoais de } \\
\text { forma desconexa. Não } \\
\text { há informaçōes sobre } \\
\text { sua evolução nem } \\
\text { sobre a causa da morte. }\end{array}$ \\
\hline DAP 108 & C.B. & M & 30 & Branca & Italiana & $\begin{array}{l}\text { Sicília, } \\
\text { Itália }\end{array}$ & Viúvo & Colono & Católica & & $\begin{array}{l}\text { Mococa, } \\
\text { SP }\end{array}$ & $1 / 14 / 1913$ & 7/25/1915 & Cura & Fotografia & $\begin{array}{l}\text { Degenerado, } \\
\text { fraco de espíri- } \\
\text { to e alcoolista }\end{array}$ & $\begin{array}{l}\text { Preso por } \\
\text { matar a } \\
\text { esposa, por } \\
\text { ciúmes, } \\
\text { quando } \\
\text { estava em- } \\
\text { briagado }\end{array}$ & $\begin{array}{l}\text { Durante o inquérito, } \\
\text { fingiu ter problemas } \\
\text { mentais para nāo ser } \\
\text { julgado e ir para a } \\
\text { cadeia. }\end{array}$ \\
\hline DAP 202 & J.F.C. & M & 19 & Branca & Brasileira & $\begin{array}{l}\text { Lorena, } \\
\text { SP }\end{array}$ & Solteiro & Baleiro & Católica & $\begin{array}{l}\text { Alfabetizado } \\
\text { (lê e escreve } \\
\text { mal) }\end{array}$ & $\begin{array}{l}\text { São Paulo, } \\
\text { SP }\end{array}$ & 2/8/1913 & & & Fotografia & $\begin{array}{l}\text { Não possui } \\
\text { diagnóstico psi- } \\
\text { copatológico, } \\
\text { somente men- } \\
\text { çãa a ataques } \\
\text { epiléticos }\end{array}$ & $\begin{array}{l}\text { Absolvido } \\
\text { (art. 27, \$ } \\
4^{\circ} \text { do Códi- } \\
\text { go Penal). } \\
\text { Esfaqueou } \\
\text { um } \\
\text { motorista } \\
\text { após uma } \\
\text { discussão }\end{array}$ & $\begin{array}{l}\text { Reportagem de } 1914 \\
\text { sobre o crime. Diz que } \\
\text { foi para o Manicômio } \\
\text { por ter sofridos ataques } \\
\text { epiléticos na prisão. }\end{array}$ \\
\hline DAP 308 & M.J. & M & 32 & Parda & Brasileira & Bahia & Solteiro & Operário & Católica & Alfabetizado & $\begin{array}{l}\text { São Paulo, } \\
\text { SP }\end{array}$ & \begin{tabular}{|l} 
09/06/1911 e \\
10/03/1913
\end{tabular} & $\begin{array}{l}21 / 09 / 1911 \\
\mathrm{e} \\
04 / 12 / 1914\end{array}$ & Cura & $\begin{array}{l}\text { Fotografia } \\
\text { e assina- } \\
\text { tura }\end{array}$ & $\begin{array}{l}\text { Síndrome } \\
\text { paranóide }\end{array}$ & $\begin{array}{l}\text { Não se } \\
\text { sabe a } \\
\text { razão da } \\
\text { prisão }\end{array}$ & $\begin{array}{l}\text { No "lugar para o } \\
\text { autógrafo", além de } \\
\text { fotografia e assinatura, } \\
\text { há um poema escrito } \\
\text { pelo interno. }\end{array}$ \\
\hline
\end{tabular}




\begin{tabular}{|c|c|c|c|c|c|c|c|c|c|c|c|c|c|c|c|c|c|c|}
\hline 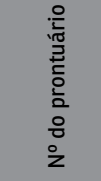 & 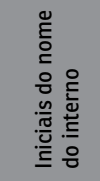 & 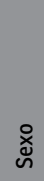 & $\begin{array}{l}\frac{0}{\pi} \\
\text { 元 }\end{array}$ & ¿̀ & $\begin{array}{l}\frac{8}{\pi} \\
\frac{\pi}{0} \\
\frac{\pi}{\pi} \\
\frac{0}{0} \\
\frac{\pi}{2} \\
\frac{\pi}{2}\end{array}$ & 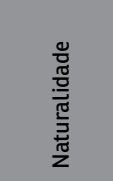 & 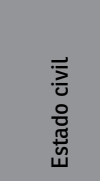 & 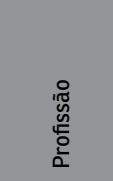 & : & 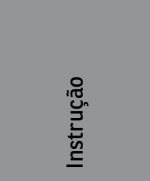 & 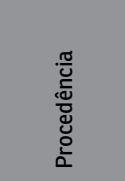 & 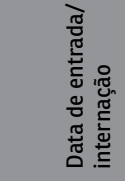 & 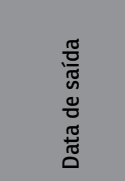 & 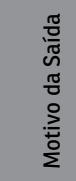 & 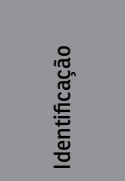 & 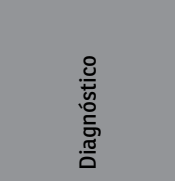 & 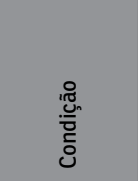 & 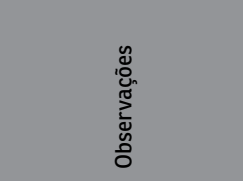 \\
\hline DAP 165 & F.P. & M & 46 & Branca & Italiana & $\begin{array}{l}\text { Coseuza, } \\
\text { Itália }\end{array}$ & Casado & Lavrador & Católica & Alfabetizado & $\begin{array}{l}\text { Taquari- } \\
\text { tinga, SP }\end{array}$ & 3/29/1913 & & & Fotografia & $\begin{array}{l}\text { Demência } \\
\text { paranóide com } \\
\text { delírios de } \\
\text { perseguiçãa }\end{array}$ & $\begin{array}{l}\text { Réu. Afirma } \\
\text { que matou } \\
\text { seu genro } \\
\text { e atentou } \\
\text { contra a } \\
\text { vida de } \\
\text { outros, por } \\
\text { serem seus } \\
\text { inimigos } \\
\text { e the } \\
\text { quererem o } \\
\text { mal. }\end{array}$ & \\
\hline DAP 203 & J.F. & M & 43 & Branca & Brasileira & $\begin{array}{l}\text { Pedreira, } \\
\text { SP }\end{array}$ & Casado & & Católica & & $\begin{array}{l}\text { Bragança, } \\
\text { SP }\end{array}$ & 3/30/1913 & 6/7/1913 & & $\begin{array}{l}\text { Fotografia } \\
\text { e assina- } \\
\text { tura }\end{array}$ & & $\begin{array}{l}\text { Matou } \\
\text { sua noiva, } \\
\text { mas se } \\
\text { entregou à } \\
\text { polícia em } \\
\text { seguida. }\end{array}$ & $\begin{array}{l}\text { No prontuário, consta } \\
\text { ser casado, mas o } \\
\text { interno se diz solteiro. } \\
\text { Diz não se lembrar do } \\
\text { crime. Não foi detec- } \\
\text { tada doença mental. } \\
\text { Levado ao manicômio } \\
\text { por sofrer ameaças na } \\
\text { cadeia. }\end{array}$ \\
\hline DAP 212 & J.M.S & M & 31 & Branca & Brasileira & $\begin{array}{l}\text { São João } \\
\text { da Boa } \\
\text { Vista, SP }\end{array}$ & Casado & $\begin{array}{l}\text { Trabalha- } \\
\text { dor }\end{array}$ & Católica & Alfabetizado & $\begin{array}{l}\text { Espírito } \\
\text { Santo do } \\
\text { Pinhal, SP }\end{array}$ & $5 / 19 / 1913$ & 6/11/1913 & Cura & Fotografia & Embriaguez & $\begin{array}{l}\text { Réu. } \\
\text { Embriaga- } \\
\text { do, feriu a } \\
\text { esposa, por } \\
\text { duvidar da } \\
\text { paternida- } \\
\text { de do filho. }\end{array}$ & \\
\hline DAP 001 & A.S. & M & 50 & Negra & Brasileira & & Casado & Roceiro & Católica & & $\begin{array}{l}\text { Limeira, } \\
\text { SP }\end{array}$ & $5 / 20 / 1913$ & 9/10/1936 & Óbito & Fotografia & $\begin{array}{l}\text { Síndrome } \\
\text { paranoide }\end{array}$ & $\begin{array}{l}\text { Réu (art. } \\
304 \text { do Có- } \\
\text { digo Penal). } \\
\text { Absolvido } \\
\text { (art. 27, } \mathbb{S} \\
4^{\circ} \text { ). Preso } \\
\text { por dar } \\
\text { uma foiçada } \\
\text { na cabeça } \\
\text { de seu pai, } \\
\text { ferindo-o } \\
\text { gravemente. }\end{array}$ & $\begin{array}{l}\text { Hipertrofia da próstata. } \\
\text { Submetido a cirurgia, } \\
\text { morreu logo depois. } \\
\text { Cópia do processo } \\
\text { criminal. }\end{array}$ \\
\hline DAP 172 & G.C. & M & 27 & Branca & Italiana & & Solteiro & Roceiro & & & $\begin{array}{l}\text { São Paulo, } \\
\text { SP }\end{array}$ & $5 / 29 / 1913$ & & & Fotografia & $\begin{array}{l}\text { Demência pre- } \\
\text { coce paranoide }\end{array}$ & Réu & $\begin{array}{l}\text { Não sabe o motivo } \\
\text { pelo qual estava preso, } \\
\text { ou porque estava no } \\
\text { manicômio. }\end{array}$ \\
\hline
\end{tabular}




\begin{tabular}{|c|c|c|c|c|c|c|c|c|c|c|c|c|c|c|c|c|c|c|}
\hline 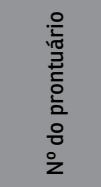 & 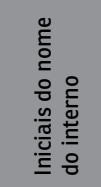 & 今̊̀ & $\begin{array}{l}\frac{\pi}{\pi} \\
\frac{\pi}{0}\end{array}$ & ¿̀ & 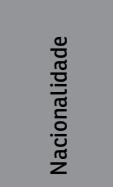 & 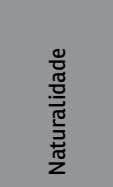 & 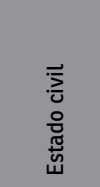 & 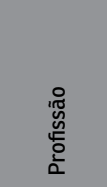 & 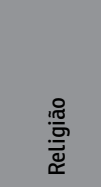 & 悹 & 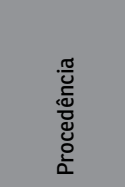 & 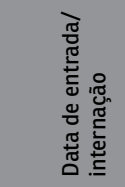 & 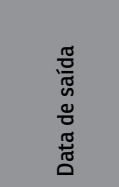 & 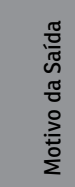 & 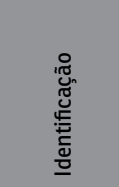 & 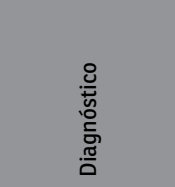 & 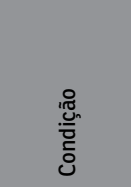 & 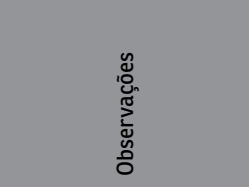 \\
\hline DAP 103 & C.J.T. & $M$ & 37 & Branca & Brasileira & $\begin{array}{l}\text { Jacareí, } \\
\text { SP }\end{array}$ & Casado & Lavrador & Católica & & Jacareí, SP & 7/5/1913 & & & Fotografia & $\begin{array}{l}\text { Degenerado, } \\
\text { imbecil e } \\
\text { alcoolista }\end{array}$ & $\begin{array}{l}\text { Réu. Matou } \\
\text { o cunhado } \\
\text { com uma } \\
\text { enxada. }\end{array}$ & $\begin{array}{l}\text { Foi mandado ao mani- } \\
\text { cômio por dizer que era } \\
\text { ruim da cabeça. }\end{array}$ \\
\hline DAP 300 & M.B. & $M$ & 22 & Branca & Brasileira & $\begin{array}{l}\text { Minas } \\
\text { Gerais }\end{array}$ & Solteiro & & Católica & Alfabetizado & & 7/19/1913 & 12/4/1913 & Cura & Fotografia & $\begin{array}{l}\text { Desequilibrado, } \\
\text { pobre de espíri- } \\
\text { to e pervertido } \\
\text { moral. }\end{array}$ & $\begin{array}{l}\text { Réu, preso } \\
\text { por furto. }\end{array}$ & $\begin{array}{l}\text { Diz ter outro nome. } \\
\text { Há cópia do processo } \\
\text { criminal. Enviado ao } \\
\text { manicômio por ensinar } \\
\text { outros presos a roubar. }\end{array}$ \\
\hline DAP 352 & R.V.G. & $M$ & 35 & Branca & $\begin{array}{l}\text { Espa- } \\
\text { nhola }\end{array}$ & & Casado & Pedreiro & Católica & & $\begin{array}{l}\text { São Paulo, } \\
\text { SP }\end{array}$ & 7/20/1913 & & & Fotografia & $\begin{array}{l}\text { Síndrome } \\
\text { paranoide }\end{array}$ & $\begin{array}{l}\text { Réu. } \\
\text { Durante } \\
\text { acesso, em } \\
\text { um hotel, } \\
\text { armou-se } \\
\text { de uma } \\
\text { faca e } \\
\text { atacou } \\
\text { diversas } \\
\text { pessoas, } \\
\text { matando } \\
\text { um preto. }\end{array}$ & $\begin{array}{l}\text { Na Cadeia Pública, } \\
\text { roubou o sabre de } \\
\text { um soldado e tentou } \\
\text { suicídio. Após esse } \\
\text { episódio, foi mandando } \\
\text { ao manicômio, por } \\
\text { sofrer das faculdades } \\
\text { mentais. Há recortes de } \\
\text { jornal sobre o caso. }\end{array}$ \\
\hline DAP 162 & F.M.S.F. & M & 28 & Branca & Brasileira & $\begin{array}{l}\text { Santos, } \\
\text { SP }\end{array}$ & Solteiro & $\begin{array}{l}\text { Comer- } \\
\text { ciante }\end{array}$ & Católica & Alfabetizado & Santos, SP & 7/23/1913 & 12/27/1913 & Cura & Fotografia & $\begin{array}{l}\text { Cleptomaníaco, } \\
\text { desequilibrado, } \\
\text { com degenera- } \\
\text { ção psíquica. }\end{array}$ & $\begin{array}{l}\text { Réu. } \\
\text { Cometia } \\
\text { furtos que } \\
\text { não sabia } \\
\text { explicar. }\end{array}$ & $\begin{array}{l}\text { Proveniente de família } \\
\text { abastada. Carta para } \\
\text { a família. Foi tratado } \\
\text { de doença em Paris. } \\
\text { Há cópia do processo } \\
\text { criminal. }\end{array}$ \\
\hline DAP 350 & P.T.M. & M & 28 & Preta & Brasileira & $\begin{array}{l}\text { Franca, } \\
\text { SP }\end{array}$ & Casado & & Católica & & Franca, SP & 7/30/1913 & & & Fotografia & Epilepsia & $\begin{array}{l}\text { Não há in- } \\
\text { formaçōes } \\
\text { sobre os } \\
\text { antece- } \\
\text { dentes ou } \\
\text { sobre o } \\
\text { crime. }\end{array}$ & \\
\hline DAP 150 & F.M. & $M$ & 24 & Branca & Italiana & $\begin{array}{l}\text { Coseuza, } \\
\text { Itália }\end{array}$ & Solteiro & $\begin{array}{l}\text { Açou- } \\
\text { gueiro }\end{array}$ & Católica & & $\begin{array}{l}\text { São Paulo, } \\
\text { SP }\end{array}$ & 8/20/1913 & & & Fotografia & $\begin{array}{l}\text { Hipótese de } \\
\text { degeneração } \\
\text { epileptoide. }\end{array}$ & Réu & $\begin{array}{l}\text { Diz ter matado um ini- } \\
\text { migo com uma facada, } \\
\text { por ter sido ameaçado } \\
\text { com um revoólver. }\end{array}$ \\
\hline
\end{tabular}




\begin{tabular}{|c|c|c|c|c|c|c|c|c|c|c|c|c|c|c|c|c|c|c|}
\hline 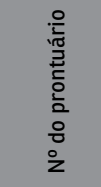 & 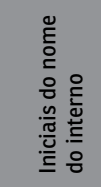 & ڤ̊̀ & $\begin{array}{l}\frac{\pi}{\pi} \\
\underline{\underline{\pi}}\end{array}$ & ¿̀ & $\begin{array}{l}\frac{\pi}{\pi} \\
\frac{\pi}{0} \\
\frac{0}{\pi} \\
\frac{0}{0} \\
\frac{\pi}{2} \\
\frac{\pi}{2}\end{array}$ & 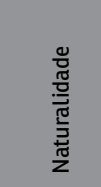 & 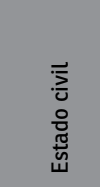 & 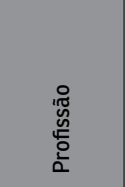 & : & 怘 & 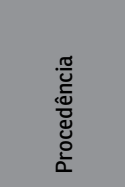 & 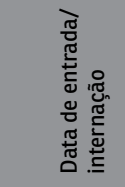 & 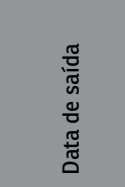 & 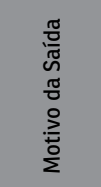 & 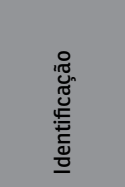 & 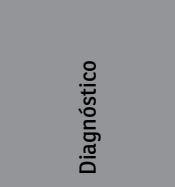 & 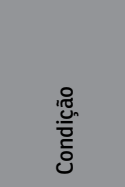 & 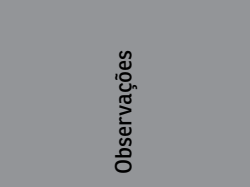 \\
\hline DAP 054 & A.F.A. & M & 25 & Parda & Brasileira & Bahia & Casado & $\begin{array}{l}\text { Trabalha- } \\
\text { dor }\end{array}$ & Católica & Alfabetizado & $\begin{array}{l}\text { Ituverava, } \\
\text { SP }\end{array}$ & 8/25/1913 & 9/19/1931 & $\begin{array}{l}\text { Trans- } \\
\text { ferência } \\
\text { para a } \\
\text { Cadeia } \\
\text { Pública } \\
\text { de Itu- } \\
\text { verava }\end{array}$ & Fotografia & $\begin{array}{l}\text { Delírio } \\
\text { alucinatório } \\
\text { pós-epilético }\end{array}$ & $\begin{array}{l}\text { Réu, por } \\
\text { homicídio. }\end{array}$ & $\begin{array}{l}\text { Internado por matar } \\
\text { um companheiro de } \\
\text { trabalho a facadas e } \\
\text { ferir outro, enquanto } \\
\text { ambos dormiam, após } \\
\text { um ataque de histeria. } \\
\text { No inquérito policial há } \\
\text { divergênncias de idade e } \\
\text { naturalidade. Há cópia } \\
\text { do processo criminal. }\end{array}$ \\
\hline DAP 009 & A.J.o. & M & 20 & Parda & Brasileira & Bahia & Solteiro & $\begin{array}{l}\text { Traba- } \\
\text { lhador da } \\
\text { lavoura }\end{array}$ & Católica & Analfabeto & $\begin{array}{l}\text { São Paulo, } \\
\text { SP }\end{array}$ & 9/17/1913 & $11 / 11 / 1937$ & Óbito & $\begin{array}{l}\text { Fotografia } \\
\text { e digitais }\end{array}$ & $\begin{array}{l}\text { Esquizofrenia } \\
\text { de forma } \\
\text { paranoide } \\
\text { predominante, } \\
\text { demência } \\
\text { precoce. }\end{array}$ & $\begin{array}{l}\text { Réu } \\
\text { (arts.13 } \\
\text { e 10), por } \\
\text { passar } \\
\text { moeda } \\
\text { falsa em } \\
\text { Araraqua- } \\
\text { ra. }\end{array}$ & $\begin{array}{l}\text { No julgamento, foi } \\
\text { enviado ao mani- } \\
\text { cômio para realizar } \\
\text { exame mental, mas } \\
\text { permaneceu lá até } \\
\text { sua morte. Atestado } \\
\text { de } 1932 \text { informa que es- } \\
\text { tava bem orientado em } \\
\text { relação ao meio, tempo } \\
\text { e pessoa. }\end{array}$ \\
\hline DAP 061 & A.M.S. & M & 42 & Branca & Brasileira & $\begin{array}{l}\text { Guareí, } \\
\text { SP }\end{array}$ & Amante & Lavrador & Católica & & Tatuí, SP & 9/17/1913 & $2 / 2 / 1932$ & $\begin{array}{l}\text { Trans- } \\
\text { ferência } \\
\text { para o } \\
\text { Hospital } \\
\text { do Ju- } \\
\text { query }\end{array}$ & Fotografia & $\begin{array}{l}\text { Alcoolismo e } \\
\text { imbecilidade }\end{array}$ & $\begin{array}{l}\text { Réu (art. } \\
294 \text { do Có- } \\
\text { digo Penal, } \\
\$ 1^{0} \text { e art. } \\
39, \$ 7^{\circ} \\
\text { do Código } \\
\text { Penal), } \\
\text { por matar } \\
\text { a amante, } \\
\text { quando } \\
\text { estava em- } \\
\text { briagado. }\end{array}$ & $\begin{array}{l}\text { Transferido para o } \\
\text { Manicômio por tentar o } \\
\text { suicídio. }\end{array}$ \\
\hline DAP 094 & B.L. & M & 48 & Parda & Brasileira & $\begin{array}{l}\text { Mogi } \\
\text { Mirim, } \\
\text { SP }\end{array}$ & Casado & Lavrador & Católica & & $\begin{array}{l}\text { Mogi } \\
\text { Mirim, SP }\end{array}$ & 10/7/1913 & & & Fotografia & $\begin{array}{l}\text { Degenerado, } \\
\text { afetado de epi- } \\
\text { lepsia física. }\end{array}$ & & $\begin{array}{l}\text { Internado no Manicô- } \\
\text { mio Judiciário por ter } \\
\text { matado seu colega de } \\
\text { cela na cadeia, pelo } \\
\text { qual parecia não ter } \\
\text { inimizade. }\end{array}$ \\
\hline DAP 013 & A.A. & M & 50 & Branca & Brasileira & $\begin{array}{l}\text { Limeira, } \\
\text { SP }\end{array}$ & Solteiro & & & Alfabetizado & $\begin{array}{l}\text { São Paulo, } \\
\text { SP }\end{array}$ & $10 / 12 / 1913$ & & & Fotografia & $\begin{array}{l}\text { Imbecil, sujeito } \\
\text { a períodos } \\
\text { de excitação } \\
\text { alucinatória. }\end{array}$ & & $\begin{array}{l}\text { Um vizinho teria man- } \\
\text { dado matá-lo. Alega ter } \\
\text { agredido em legitima } \\
\text { defesa e que nāo se } \\
\text { arrepende, porque o } \\
\text { homem era negro e } \\
\text { "negro não é gente". } \\
\text { Uma das testemunhas } \\
\text { no inquérito alega que } \\
\text { ele tinha relaçōes se- } \\
\text { xuais com as galinhas e } \\
\text { era louco. }\end{array}$ \\
\hline
\end{tabular}




\begin{tabular}{|c|c|c|c|c|c|c|c|c|c|c|c|c|c|c|c|c|c|c|}
\hline 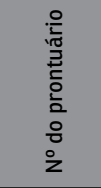 & 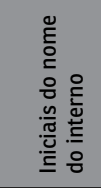 & ঙั̀े & $\begin{array}{l}\frac{\tilde{\pi}}{\pi} \\
\frac{\pi}{0}\end{array}$ & ¿̀ & $\begin{array}{l}\frac{0}{\pi} \\
\frac{\pi}{0} \\
\frac{\pi}{\pi} \\
\frac{0}{0} \\
\frac{\pi}{2}\end{array}$ & 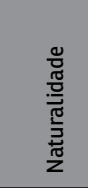 & 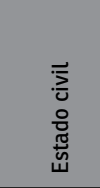 & 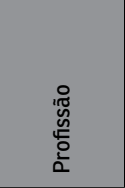 & $\frac{10}{\frac{10}{\pi}}$ & 空 & 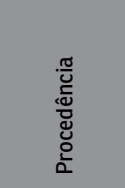 & 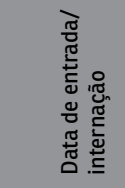 & $\begin{array}{l}\frac{\pi}{0} \\
\frac{\pi}{\pi} \\
0 \\
\frac{0}{\pi} \\
\frac{\pi}{0}\end{array}$ & 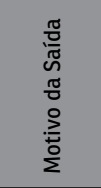 & 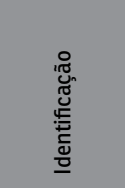 & 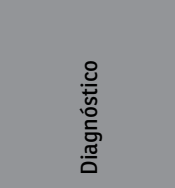 & 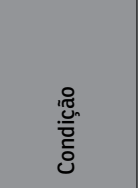 & 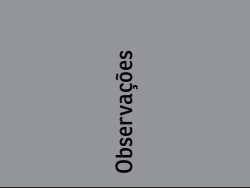 \\
\hline DAP 392 & V.F.M. & M & 25 & Preta & Brasileira & $\begin{array}{l}\text { Santa } \\
\text { Rita do } \\
\text { Passa } \\
\text { Quatro, } \\
\text { SP } \\
\end{array}$ & Casado & $\begin{array}{l}\text { Traba- } \\
\text { lhador da } \\
\text { lavoura }\end{array}$ & Católica & & $\begin{array}{l}\text { Santa Rita } \\
\text { do Passa } \\
\text { Quatro, } \\
\text { SP }\end{array}$ & $10 / 12 / 1913$ & & & Fotografia & $\begin{array}{l}\text { Degeneraçāo, } \\
\text { imbecilidade, } \\
\text { com episódios } \\
\text { delirantes. }\end{array}$ & $\begin{array}{l}\text { Preso por } \\
\text { atirar em } \\
\text { seu compa- } \\
\text { dre. }\end{array}$ & $\begin{array}{l}\text { Segundo testemunhas, } \\
\text { seria desequilibrado. }\end{array}$ \\
\hline DAP 355 & R.A. & M & & Branca & Italiana & Itália & Casado & & & & $\begin{array}{l}\text { São Paulo, } \\
\text { SP }\end{array}$ & $11 / 30 / 1913$ & $11 / 11 / 1963$ & $\begin{array}{l}\text { Trans- } \\
\text { ferência } \\
\text { para o } \\
\text { Hospital } \\
\text { do Ju- } \\
\text { query }\end{array}$ & Fotografia & $\begin{array}{l}\text { Esquizofrenia, } \\
\text { demência } \\
\text { precoce. }\end{array}$ & $\begin{array}{l}\text { Réu (art. } \\
294 \text { do } \\
\text { Código } \\
\text { Penal, } \$ 1 \\
\text { do Código } \\
\text { Penal). }\end{array}$ & $\begin{array}{l}\text { Não foi possível saber } \\
\text { os antecedentes, pois } \\
\text { o arquivo do Seguindo } \\
\text { Ofíio do Júri foi } \\
\text { queimado durante a } \\
\text { Revoluçãoo de 1924. } \\
\text { Mandado ao manicômio } \\
\text { para ser examinado, } \\
\text { pois não comia havia } \\
15 \text { dias. }\end{array}$ \\
\hline DAP 059 & A.J.B. & M & 32 & Parda & Brasileira & Bahia & Solteiro & $\begin{array}{l}\text { Soldado } \\
\text { da polícia }\end{array}$ & Católica & & & $12 / 24 / 1913$ & $12 / 28 / 1913$ & Cura & Fotografia & $\begin{array}{l}\text { Epilepsia } \\
\text { psíquica }\end{array}$ & Réu & $\begin{array}{l}\text { Brigou com seus } \\
\text { colegas "desordei- } \\
\text { ros", ferindo alguns } \\
\text { e matando um deles. } \\
\text { Recorte de jornal sobre } \\
\text { o crime. Há cópia do } \\
\text { processo criminal. }\end{array}$ \\
\hline DAP 121 & D.P. & $\mathrm{F}$ & & Parda & Brasileira & & & & & Analfabeta & São Luís & 2/25/1914 & & & Fotografia & Imbecil & $\begin{array}{l}\text { Ré, por ter } \\
\text { afogado } \\
\text { seu filho } \\
\text { mais novo. }\end{array}$ & $\begin{array}{l}\text { Anamnese com infor- } \\
\text { maçōes incompletas. } \\
\text { Consta exame psíquico, } \\
\text { mas não a evoluçāo. }\end{array}$ \\
\hline DAP 389 & V.G. & M & 58 & Branca & Italiana & Itália & Casado & Lavrador & Católica & & Araras, SP & 3/30/1914 & & & Fotografia & $\begin{array}{l}\text { Delírio alu- } \\
\text { cinatório de } \\
\text { perseguição }\end{array}$ & Réu & $\begin{array}{l}\text { Não consta evolução do } \\
\text { interno. Há correspon- } \\
\text { dência. }\end{array}$ \\
\hline DAP 038 & A.M. & M & 43 & Branca & Italiana & Itália & Casado & & & Analfabeto & $\begin{array}{l}\text { São Car- } \\
\text { los, SP }\end{array}$ & 5/17/1914 & & & Fotografia & $\begin{array}{l}\text { Alcoolismo } \\
\text { crônico }\end{array}$ & Réu & $\begin{array}{l}\text { Não há detalhes } \\
\text { sobre o crime, apenas } \\
\text { mençōes sobre o depoi- } \\
\text { mento, que não consta } \\
\text { no prontuário. Há } \\
\text { exame psíquico, mas } \\
\text { não consta a evolução } \\
\text { do interno. }\end{array}$ \\
\hline DAP 252 & J.J. & M & 31 & Branca & Italiana & Itália & Solteiro & $\begin{array}{l}\text { Trabalha- } \\
\text { dor }\end{array}$ & $\begin{array}{l}\text { Sem } \\
\text { religiāo }\end{array}$ & $\begin{array}{l}\text { Alfabetizado } \\
\text { (lê e escreve } \\
\text { mal) }\end{array}$ & Atibaia, SP & $5 / 22 / 1914$ & & & Fotografia & $\begin{array}{l}\text { Degenerado, } \\
\text { alcoolismo. }\end{array}$ & Réu & $\begin{array}{l}\text { Considerado perigoso } \\
\text { para a sociedade. } \\
\text { Não consta motivo da } \\
\text { prisão, nem a causa da } \\
\text { internação. }\end{array}$ \\
\hline DAP 330 & P.S. & M & & & & & Solteiro & & & Alfabetizado & $\begin{array}{l}\text { São Paulo, } \\
\text { SP }\end{array}$ & 7/22/1914 & & & Fotografia & $\begin{array}{l}\text { Degenerado, al- } \\
\text { coolista, delírio } \\
\text { sistemático } \\
\text { alucinatório, } \\
\text { paranoide, atos } \\
\text { impulsivos e } \\
\text { epileptoides. }\end{array}$ & Réu & $\begin{array}{l}\text { Assassinou o cunhado } \\
\text { por este dizer que ele } \\
\text { era pederasta. }\end{array}$ \\
\hline
\end{tabular}




\begin{tabular}{|c|c|c|c|c|c|c|c|c|c|c|c|c|c|c|c|c|c|c|}
\hline 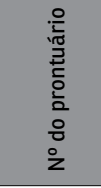 & 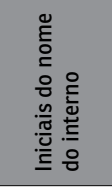 & ڤั̀ & $\begin{array}{l}\frac{\pi}{\pi} \\
\text { 五 }\end{array}$ & ¿̀ & $\begin{array}{l}\frac{2}{\pi} \\
\frac{\pi}{0} \\
\frac{0}{\pi} \\
\frac{5}{0} \\
\frac{0}{2}\end{array}$ & $\begin{array}{l}\frac{\pi}{\pi} \\
\frac{\pi}{0} \\
\frac{\pi}{\pi} \\
\frac{\pi}{2} \\
\frac{\pi}{2}\end{array}$ & 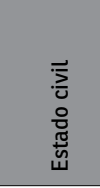 & 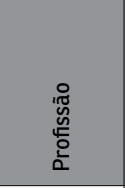 & $\frac{10}{\frac{10}{5}}$ & 突 & 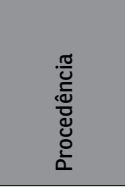 & 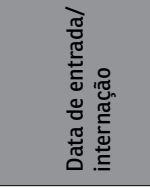 & 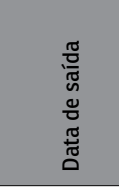 & 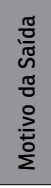 & 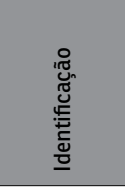 & 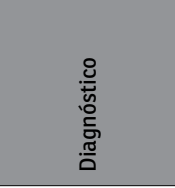 & 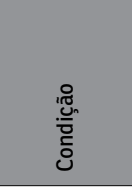 & 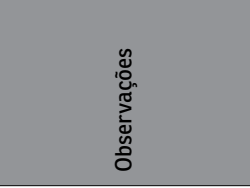 \\
\hline DAP 109 & $\begin{array}{l}\text { C.J. (vul- } \\
\text { go Rio) }\end{array}$ & M & 25 & Branca & Síria & Síria & Solteiro & & & & $\begin{array}{l}\text { São Pau- } \\
\text { lo,SP }\end{array}$ & $8 / 7 / 1914$ & & & Fotografia & $\begin{array}{l}\text { Síndrome } \\
\text { catatônica }\end{array}$ & $\begin{array}{l}\text { Réu, por } \\
\text { assassi- } \\
\text { nato. }\end{array}$ & $\begin{array}{l}\text { Recorte de jornal sobre } \\
\text { o crime. }\end{array}$ \\
\hline DAP 207 & J.I.C. & M & 39 & Preta & Brasileira & & Casado & $\begin{array}{l}\text { Trabalha- } \\
\text { dor }\end{array}$ & Católica & & $\begin{array}{l}\text { Peniten- } \\
\text { ciária do } \\
\text { Estado, } \\
\text { SP }\end{array}$ & 9/19/1914 & & & Fotografia & $\begin{array}{l}\text { Demência } \\
\text { precoce }\end{array}$ & Réu & $\begin{array}{l}\text { Segunda entrada. Não } \\
\text { consta nenhuma infor- } \\
\text { mação sobre o crime. } \\
\text { Não consta evolução do } \\
\text { interno. }\end{array}$ \\
\hline DAP 242 & J.D. & M & 58 & Branca & Italiana & & Casado & & & & Tietê, SP & 10/8/1914 & & & Fotografia & $\begin{array}{l}\text { Enfraqueci- } \\
\text { mento psico } \\
\text { pré-senil, por } \\
\text { abuso de } \\
\text { álcool. }\end{array}$ & Réu & $\begin{array}{l}\text { Preso a partir de de- } \\
\text { núncia da esposa, pois } \\
\text { o paciente não permitia } \\
\text { que se realizasse o } \\
\text { casamento de sua filha. }\end{array}$ \\
\hline DAP 317 & N.L. & M & 36 & Branca & Espanhola & & Solteiro & $\begin{array}{l}\text { Trabalha- } \\
\text { dor }\end{array}$ & Católica & Analfabeto & $\begin{array}{l}\text { Ribeirão } \\
\text { Preto, SP }\end{array}$ & $11 / 21 / 1914$ & & & Fotografia & $\begin{array}{l}\text { Degenerado } \\
\text { com episódio } \\
\text { delirante, for- } \\
\text { ma paranoide. }\end{array}$ & $\begin{array}{l}\text { Réu por } \\
\text { homicídio }\end{array}$ & $\begin{array}{l}\text { Crime cometido em } \\
\text { estado de embriaguez. } \\
\text { Encaminhado da prisão } \\
\text { para o hospício, devido } \\
\text { a barulhos contínuos e } \\
\text { suspeita de demência. }\end{array}$ \\
\hline DAP 122 & D.A. & M & 24 & Preta & Brasileira & & Viúvo & $\begin{array}{l}\text { Traba- } \\
\text { lhador de } \\
\text { lavoura }\end{array}$ & Católica & Analfabeto & Tietê, SP & $11 / 27 / 1914$ & & & Fotografia & $\begin{array}{l}\text { Imbecil, síndro- } \\
\text { me paranoide, } \\
\text { delírio de } \\
\text { perseguição. }\end{array}$ & $\begin{array}{l}\text { Réu (art. } \\
\text { 303), } \\
\text { acusado } \\
\text { de roubo, } \\
\text { assassinato } \\
\text { e feitiçaria. }\end{array}$ & $\begin{array}{l}\text { Exame psíquico. Não } \\
\text { consta evoluçāo do do } \\
\text { interno. Chegando à } \\
\text { cidade de Tietê, foi } \\
\text { enviado à prisão e ali } \\
\text { roubou o sabre de um } \\
\text { soldado e desferiu gol- } \\
\text { pes. Encaminhado para } \\
\text { exame de sanidade } \\
\text { mental, constatou-se } \\
\text { sintomas de perturba- } \\
\text { çāo psíquica. }\end{array}$ \\
\hline DAP 187 & J.D. & M & 26 & Branca & Síria & Síria & Solteiro & & & & $\begin{array}{l}\text { Peniten- } \\
\text { ciária do } \\
\text { Estado, } \\
\text { SP }\end{array}$ & $\begin{array}{l}\text { 01/01/1915, } \\
27 / 09 / 1915 \text { e } \\
07 / 01 / 1921\end{array}$ & 4/11/1915 & & Fotografia & $\begin{array}{l}\text { Degenerado, } \\
\text { com um delírio } \\
\text { episódico hipo- } \\
\text { condríaco. }\end{array}$ & Réu & $\begin{array}{l}\text { Sofria de verminose, } \\
\text { descrevendo incômodos } \\
\text { na hora de comer. }\end{array}$ \\
\hline DAP 084 & B. S. & M & 35 & Branca & Italiana & & Casado & Mecânico & Católica & & $\begin{array}{l}\text { São Paulo, } \\
\text { SP }\end{array}$ & 2/20/1915 & & & Fotografia & $\begin{array}{l}\text { Uso frequente } \\
\text { de álcool, } \\
\text { epilepsia }\end{array}$ & $\begin{array}{l}\text { Réu, por } \\
\text { homicídio. }\end{array}$ & $\begin{array}{l}\text { Crime de homicídio. } \\
\text { Perfeita noçāo de } \\
\text { tempo e espacoo. } \\
\text { Afirma embriagar-se } \\
\text { semanalmente. Não } \\
\text { foi percebida nenhuma } \\
\text { moléstia mental. Sofria } \\
\text { de "tonteira". }\end{array}$ \\
\hline
\end{tabular}




\begin{tabular}{|c|c|c|c|c|c|c|c|c|c|c|c|c|c|c|c|c|c|c|}
\hline 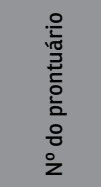 & 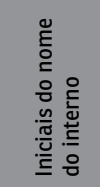 & 㐫 & 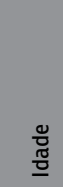 & ¿̀ & $\begin{array}{l}\frac{\pi}{\pi} \\
\frac{\pi}{0} \\
\frac{\pi}{\pi} \\
\frac{0}{0} \\
\frac{\pi}{2} \\
\frac{\pi}{2}\end{array}$ & 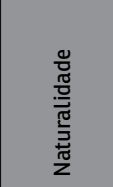 & 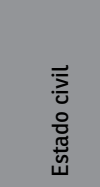 & 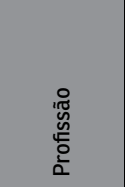 & $\begin{array}{l}\frac{\pi}{\pi} \\
\frac{\pi}{\pi} \\
\frac{\pi}{\pi}\end{array}$ & 总 & 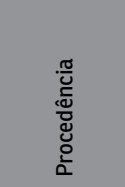 & 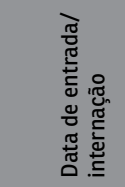 & 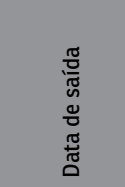 & 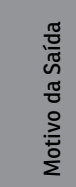 & 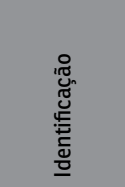 & 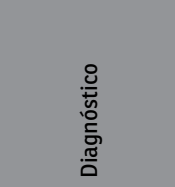 & 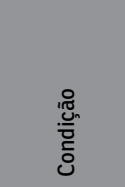 & 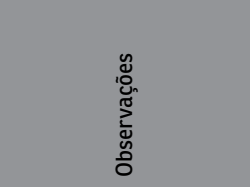 \\
\hline DAP 145 & F.O.M. & M & 31 & Preta & Brasileira & & Casado & $\begin{array}{l}\text { Maqui- } \\
\text { nista }\end{array}$ & Católica & Alfabetizado & $\begin{array}{l}\text { São Paulo, } \\
\text { SP }\end{array}$ & 2/23/1915 & 9/10/1915 & Cura & Fotografia & Degeneração & $\begin{array}{l}\text { Réu, por } \\
\text { homicídio. }\end{array}$ & $\begin{array}{l}\text { Tem perfeita noção } \\
\text { de tempo, meio e } \\
\text { espaço, "não manifesta } \\
\text { confusão de espírito". } \\
\text { Respostas claras, hu- } \\
\text { mor variável. Segundo } \\
\text { o interno, "sempre } \\
\text { abusou de bebidas } \\
\text { alcoólicas". Tempera- } \\
\text { mento difíil,, agredindo } \\
\text { outros pacientes. }\end{array}$ \\
\hline DAP 132 & E.M.L. & M & 47 & Branca & Grega & Grécia & Casado & & & & Santos, SP & 2/27/1915 & & Óbito & $\begin{array}{l}\text { Fotografia } \\
\text { e digitais }\end{array}$ & $\begin{array}{l}\text { Síndrome } \\
\text { paranoide. }\end{array}$ & $\begin{array}{l}\text { Réu (art. } \\
294 \text { do } \\
\text { Código } \\
\text { Penal, } \$ 2^{\circ} \\
\text { do Código } \\
\text { Penal). }\end{array}$ & $\begin{array}{l}\text { Vaga noçāo de tempo } \\
\text { e meio. }\end{array}$ \\
\hline DAP 288 & L.L. & M & 45 & Branca & Italiana & & Casado & Colono & Católica & $\begin{array}{l}\text { Alfabetizado } \\
\text { (sabe ler) }\end{array}$ & $\begin{array}{l}\text { Taquari- } \\
\text { tinga, SP }\end{array}$ & 3/1/1915 & $5 / 14 / 1936$ & Óbito & Fotografia & $\begin{array}{l}\text { Síndrome } \\
\text { paranoide, } \\
\text { alucinaçōes au- } \\
\text { ditivas, delírios } \\
\text { de perseguição } \\
\text { e grandeza. }\end{array}$ & $\begin{array}{l}\text { Réu, por } \\
\text { homicídio. }\end{array}$ & $\begin{array}{l}\text { Boa noção de tempo } \\
\text { e meio. Tuberculose } \\
\text { pulmonar e intestinal, } \\
\text { falecendo por isso. } \\
\text { Dizia ouvir vozes e ver } \\
\text { pessoas mortas. }\end{array}$ \\
\hline DAP 158 & F.G.V. & M & 40 & Branca & Espanhola & Espanha & Casado & & & & $\begin{array}{l}\text { Taquari- } \\
\text { tinga, SP }\end{array}$ & 4/15/1915 & & & Fotografia & $\begin{array}{l}\text { Degenerado } \\
\text { e delirante de } \\
\text { caráter perse- } \\
\text { cutório, fazia } \\
\text { uso de álcool. }\end{array}$ & Réu & $\begin{array}{l}\text { Sem noção de tempo } \\
\text { e meio, respondia tar- } \\
\text { diamente e sem nexo. } \\
\text { Dizia ser perseguido } \\
\text { pelo cunhado. }\end{array}$ \\
\hline DAP 210 & J.M.A. & M & 46 & Preta & Brasileira & & Solteiro & & & & $\begin{array}{l}\text { São Paulo, } \\
\text { SP }\end{array}$ & 6/12/1915 & & & Fotografia & $\begin{array}{l}\text { Demência } \\
\text { paranoide }\end{array}$ & Réu & Terceira entrada. \\
\hline DAP 011 & A. 0. & M & 16 & Branca & Brasileira & & Solteiro & Copeiro & Católica & Alfabetizado & $\begin{array}{l}\text { São Paulo, } \\
\text { SP }\end{array}$ & $7 / 8 / 1915$ & & & Fotografia & $\begin{array}{l}\text { Imoralidade } \\
\text { constitucional }\end{array}$ & Réu & $\begin{array}{l}\text { Fugiu de casa aos } 9 \\
\text { anos, tendência a vaga- } \\
\text { bundagem e ao furto. } \\
\text { Sem caráter. Perfeita } \\
\text { noção de tempo e meio, } \\
\text { humor constante. Es- } \\
\text { creve carta para Franco } \\
\text { da Rocha, pedindo } \\
\text { liberdade. Enviado ao } \\
\text { manicômio devido à } \\
\text { sua agitação na cadeia. }\end{array}$ \\
\hline DAP 365 & S.A. & M & 32 & Branca & Italiana & & Casado & Carvoeiro & Católica & $\begin{array}{l}\text { Alfabetizado } \\
\text { (rudimentar) }\end{array}$ & $\begin{array}{l}\text { São Paulo, } \\
\text { SP }\end{array}$ & 8/7/1915 & & & Fotografia & $\begin{array}{l}\text { Degenerado de } \\
\text { delírio alucina- } \\
\text { tório, síndrome } \\
\text { paranoide. }\end{array}$ & $\begin{array}{l}\text { Réu, por } \\
\text { esfaque- } \\
\text { ar um } \\
\text { homem. } \\
\text { Preso } \\
\text { antes, por } \\
\text { matar um } \\
\text { homem } \\
\text { com um } \\
\text { guarda- } \\
\text {-chuva. }\end{array}$ & $\begin{array}{l}\text { Afirma nāo ter noçāo } \\
\text { de tempo e ser per- } \\
\text { seguido por espíritos } \\
\text { que o obrigam contra } \\
\text { a vontade. Tentou sui- } \\
\text { cídio na cadeia. Seus } \\
\text { problemas decorriam } \\
\text { de sessōes espiritas na } \\
\text { vizinhança, onde esfa- } \\
\text { queou um homem. }\end{array}$ \\
\hline
\end{tabular}




\begin{tabular}{|c|c|c|c|c|c|c|c|c|c|c|c|c|c|c|c|c|c|c|}
\hline 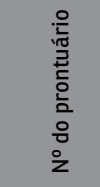 & 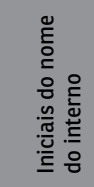 & ঙ̊̀̀ & $\begin{array}{l}\frac{8}{\pi} \\
\frac{\pi}{0}\end{array}$ & ò & $\begin{array}{l}\frac{\pi}{\pi} \\
\frac{\pi}{\pi} \\
\frac{\pi}{\pi} \\
\check{0} \\
\frac{0}{\pi} \\
\frac{\pi}{2}\end{array}$ & 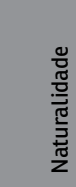 & 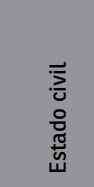 & 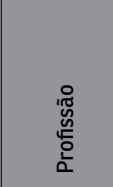 & $\begin{array}{l}\frac{10}{\pi} \\
\frac{\pi}{\pi} \\
\frac{\pi}{\pi}\end{array}$ & 莺 & 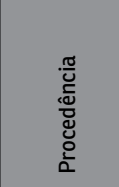 & 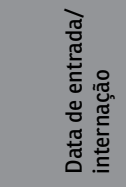 & 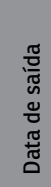 & $\begin{array}{l}\frac{\pi}{0} \\
\frac{\pi}{\pi} \\
\frac{\pi}{\pi} \\
0 \\
\stackrel{0}{0} \\
\sum\end{array}$ & 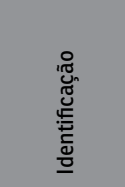 & 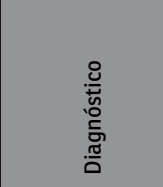 & 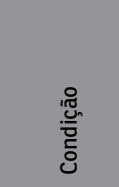 & 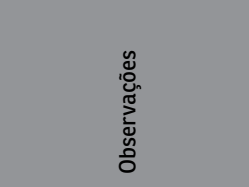 \\
\hline DAP 304 & M.F.S. & M & 50 & Preta & Brasileira & Bahia & Casado & & & Analfabeto & $\begin{array}{l}\text { Amparo, } \\
\text { SP }\end{array}$ & 9/15/1915 & & & Fotografia & Epilepsia & $\begin{array}{l}\text { Réu, crime } \\
\text { não infor- } \\
\text { mado. }\end{array}$ & $\begin{array}{l}\text { Boa noção de espaço } \\
\text { e meio. Antes e depois } \\
\text { de sofrer ataques, } \\
\text { apresenta certo grau de } \\
\text { confusão. }\end{array}$ \\
\hline DAP 027 & A.B.S. & M & 21 & Preta & Brasileira & & Solteiro & Lavrador & Católica & & $\begin{array}{l}\text { Caconde, } \\
\text { SP }\end{array}$ & 9/19/1915 & & & Fotografia & Epilético & $\begin{array}{l}\text { Preso por } \\
\text { agredir } \\
\text { a mãe, } \\
\text { quando } \\
\text { esta apar- } \\
\text { tava um } \\
\text { discussão } \\
\text { entre ele e } \\
\text { sua irmã. }\end{array}$ & $\begin{array}{l}\text { Ataques convulsivos } \\
\text { desde os } 15 \text { anos. Boa } \\
\text { noção de tempo e } \\
\text { meio, humor tristonho. } \\
\text { Imaginaçāo pobre. }\end{array}$ \\
\hline DAP 186 & J.A.F. & M & 46 & Branca & Brasileira & & Casado & & & & $\begin{array}{l}\text { Sorocaba, } \\
\text { SP }\end{array}$ & 9/25/1915 & & & Fotografia & $\begin{array}{l}\text { L.M.D, uso de } \\
\text { álcool }\end{array}$ & Réu & $\begin{array}{l}\text { Afirma que seu pai, } \\
\text { irmāo e tio sofreram } \\
\text { das faculdades men- } \\
\text { tais. Tem boa noção } \\
\text { de tempo e meio. Não } \\
\text { manifesta ilusōes, alu- } \\
\text { cinaçōes ou delírio. }\end{array}$ \\
\hline DAP 338 & P.B. & M & 20 & Preta & Brasileira & & Solteiro & Lavrador & Católica & Analfabeto & $\begin{array}{l}\text { Capivari, } \\
\text { SP }\end{array}$ & 9/26/1915 & & & Fotografia & $\begin{array}{l}\text { Demência } \\
\text { precoce, } \\
\text { alucinaçōes } \\
\text { auditivas. }\end{array}$ & Réu & $\begin{array}{l}\text { Noção de tempo e meio } \\
\text { imperfeita. As aluci- } \\
\text { naçōes "são vozes dos } \\
\text { santos enviados por } \\
\text { Deus". Alegava que os } \\
\text { mesmos santos diziam } \\
\text { que estava casado, } \\
\text { logo, foi até a cidade } \\
\text { procurar a mulher, } \\
\text { por esse motivo sendo } \\
\text { preso. }\end{array}$ \\
\hline DAP 140 & E.A.S. & M & 29 & Preta & Brasileira & & Solteiro & & & & $\begin{array}{l}\text { Bananal, } \\
\text { SP }\end{array}$ & $10 / 7 / 1915$ & & & Fotografia & $\begin{array}{l}\text { Imbecilidade, } \\
\text { com episódios } \\
\text { de excitação } \\
\text { paranoica. }\end{array}$ & & $\begin{array}{l}\text { Possui noção do meio } \\
\text { e tempoo Respostas } \\
\text { claras, humor variável. } \\
\text { Deixava o posto de tra- } \\
\text { balho por "preguiça". } \\
\text { Era obediente. }\end{array}$ \\
\hline
\end{tabular}




\begin{tabular}{|c|c|c|c|c|c|c|c|c|c|c|c|c|c|c|c|c|c|c|}
\hline 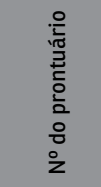 & 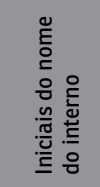 & ڤ̊̀̆ & $\begin{array}{l}\frac{\pi}{\pi} \\
\frac{\pi}{0}\end{array}$ & ¿̀ & $\begin{array}{l}\frac{\pi}{\pi} \\
\frac{\pi}{0} \\
\frac{\pi}{\pi} \\
\frac{0}{0} \\
\frac{\pi}{2}\end{array}$ & 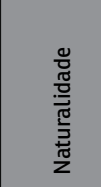 & 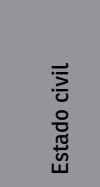 & 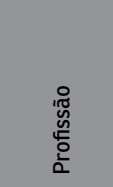 & 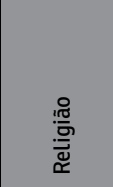 & 悹 & 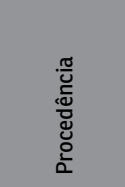 & 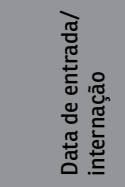 & 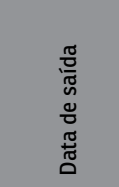 & 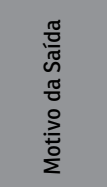 & 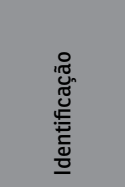 & 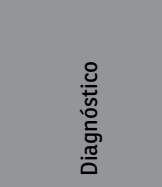 & 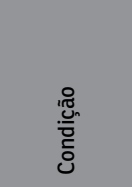 & 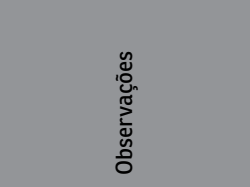 \\
\hline DAP 127 & D.L.C. & M & 26 & Branca & Brasileira & & Viúvo & & Católica & & $\begin{array}{l}\text { São Paulo, } \\
\text { SP }\end{array}$ & $10 / 29 / 1915$ & $5 / 16 / 1931$ & $\begin{array}{l}\text { Absol- } \\
\text { vido e } \\
\text { confiado } \\
\text { a um } \\
\text { curador }\end{array}$ & Fotografia & $\begin{array}{l}\text { Psicose } \\
\text { sistematizada } \\
\text { interpretativa }\end{array}$ & $\begin{array}{l}\text { Réu, por } \\
\text { homicídio } \\
\text { contra a } \\
\text { esposa. Ab- } \\
\text { solvido em } \\
\text { razāo de } \\
\text { seu estado } \\
\text { de dege- } \\
\text { neração } \\
\text { mental no } \\
\text { momento } \\
\text { do crime. }\end{array}$ & $\begin{array}{l}\text { O pai do interno sofreu } \\
\text { de embolia cerebral, } \\
\text { um de seus tios morreu } \\
\text { louco, sua mãe estava } \\
\text { internada em mani- } \\
\text { cômio. Por ciúmes, } \\
\text { matou a esposa. Seus } \\
\text { antecedentes familiares } \\
\text { justificam sua condição. }\end{array}$ \\
\hline DAP 149 & F.R. & M & 21 & Branca & Italiana & $\begin{array}{l}\text { Veneza, } \\
\text { Itália }\end{array}$ & Viúvo & Lavrador & & & $\begin{array}{l}\text { Bragança, } \\
\text { SP }\end{array}$ & $10 / 29 / 1915$ & 4/11/1943 & Alta & $\begin{array}{l}\text { Fotografia } \\
\text { e digitais }\end{array}$ & $\begin{array}{l}\text { Síndrome } \\
\text { paranoide }\end{array}$ & $\begin{array}{l}\text { Réu, por } \\
\text { homicídio } \\
\text { contra a } \\
\text { esposa. }\end{array}$ & $\begin{array}{l}\text { Sem noção do tempo. } \\
\text { Reservado. Não quer } \\
\text { regressar ao meio } \\
\text { social, trabalha no } \\
\text { setor de costuras. Não } \\
\text { é delirante. Durante a } \\
\text { estadia no manicômio, } \\
\text { conservou-se longe dos } \\
\text { outros pacientes. }\end{array}$ \\
\hline DAP 091 & B.G.M. & M & 37 & Branca & Brasileira & & Casado & & & & $\begin{array}{l}\text { São } \\
\text { Manuel, } \\
\text { SP }\end{array}$ & $11 / 19 / 1915$ & & & Fotografia & $\begin{array}{l}\text { Síndrome } \\
\text { paranoide }\end{array}$ & $\begin{array}{l}\text { Réu, crime } \\
\text { nāo infor- } \\
\text { mado. }\end{array}$ & $\begin{array}{l}\text { Tem boa noção de tem- } \\
\text { po e meio. Respostas } \\
\text { claras. Afirma "nada } \\
\text { sofrer". Considerado } \\
\text { bom, trabalhador e } \\
\text { obediente. }\end{array}$ \\
\hline 0377 & s.c.s. & M & 33 & Branca & Brasileira & $\begin{array}{l}\text { Guaru- } \\
\text { lhos, SP }\end{array}$ & Viúvo & Lavrador & Católica & Analfabeto & $\begin{array}{l}\text { São Paulo, } \\
\text { SP }\end{array}$ & 12/3/1915 & 10/8/1947 & $\begin{array}{l}\text { Trans- } \\
\text { ferência } \\
\text { para a } \\
\text { Casa de } \\
\text { Deten- } \\
\text { ção }\end{array}$ & $\begin{array}{l}\text { Fotografia } \\
\text { e digitais }\end{array}$ & $\begin{array}{l}\text { Periculosida- } \\
\text { de eventual, } \\
\text { ocasionada } \\
\text { por episódios } \\
\text { febris. }\end{array}$ & $\begin{array}{l}\text { Réu, por } \\
\text { homicídio } \\
\text { contra a } \\
\text { esposa. }\end{array}$ & $\begin{array}{l}\text { Não tem ideia de tempo } \\
\text { e lugar. Depressivo. } \\
\text { Alega traição da espo- } \\
\text { sa. Poucas informaçōes } \\
\text { sobre antecedentes, } \\
\text { uma vez que o arquivo } \\
\text { onde se localizava o } \\
\text { processo foi incendiado. }\end{array}$ \\
\hline DAP 273 & J.A.N. & M & 30 & Branca & Brasileira & & Solteiro & & & & $\begin{array}{l}\text { Taubaté, } \\
\text { SP }\end{array}$ & $12 / 31 / 1915$ & & & Fotografia & L.M.D. & Réu & $\begin{array}{l}\text { Sem noçāo de tempo e } \\
\text { meio. Apresenta delírio } \\
\text { e ilusōes. Afirma que } \\
\text { nāo sofre nada e se } \\
\text { sente feliz no mani- } \\
\text { cômio. }\end{array}$ \\
\hline DAP 257 & J.J.S. & M & & Branca & & & & & & & Cajuru, SP & 4/27/1916 & & & Fotografia & Imbecilidade & & \\
\hline
\end{tabular}




\begin{tabular}{|c|c|c|c|c|c|c|c|c|c|c|c|c|c|c|c|c|c|c|}
\hline 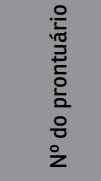 & 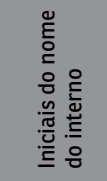 & ঙ̊̊̀̊ & 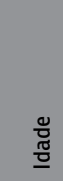 & ¿̀ & 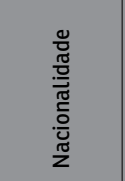 & 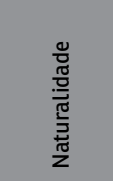 & 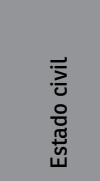 & 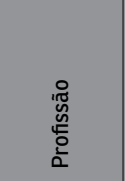 & 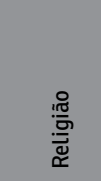 & 突 & 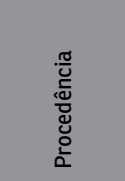 & 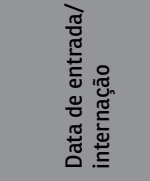 & 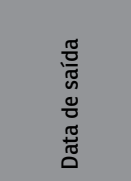 & 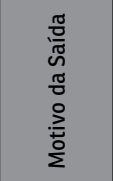 & 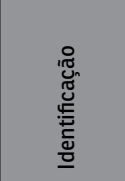 & 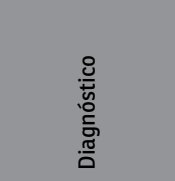 & 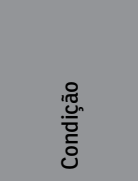 & 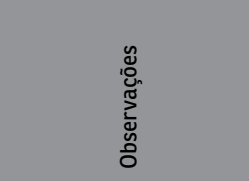 \\
\hline DAP 163 & $\begin{array}{l}\text { F.P.L. } \\
\text { (vulgo } \\
\text { João } \\
\text { Luciano) }\end{array}$ & M & 43 & Branca & Italiana & & Casado & Colono & Católica & & $\begin{array}{l}\text { Mococa, } \\
\text { SP }\end{array}$ & $5 / 29 / 1916$ & $10 / 14 / 1940$ & Óbito & Fotografia & $\begin{array}{l}\text { Síndrome pa- } \\
\text { ranoide, estado } \\
\text { demencial. }\end{array}$ & $\begin{array}{l}\text { Réu, por } \\
\text { homicídio. }\end{array}$ & $\begin{array}{l}\text { Matou o noivo de sua } \\
\text { sobrinha, que queria } \\
\text { a fortuna da moça. } \\
\text { Telegramas informando } \\
\text { sobre o falecimento do } \\
\text { interno, cartas do filho, } \\
\text { do irmāo e da mulher } \\
\text { buscando informa- } \\
\text { çôes. Manuscritos do } \\
\text { inquérito. }\end{array}$ \\
\hline DAP 157 & F.G. & M & 26 & Branca & Brasileira & $\begin{array}{l}\text { Piracica- } \\
\text { ba, SP }\end{array}$ & Solteiro & Chauffeur & & Alfabetizado & $\begin{array}{l}\text { Peniten- } \\
\text { ciária do } \\
\text { Estado, } \\
\text { SP }\end{array}$ & 7/20/1916 & & & Fotografia & $\begin{array}{l}\text { Síndrome } \\
\text { paranoide }\end{array}$ & Réu & $\begin{array}{l}\text { Encaminhado para o } \\
\text { manicômio após ter } \\
\text { alucinaçōos de per- } \\
\text { seguiçāo no presídio. } \\
\text { Entrou em um conflito, } \\
\text { quando era motorista, } \\
\text { responsabilizado pela } \\
\text { morte de um soldado } \\
\text { que interviu no con- } \\
\text { fronto. }\end{array}$ \\
\hline DAP 279 & L.R. & M & 50 & Branca & Brasileira & $\begin{array}{l}\text { Água } \\
\text { Preta, PE }\end{array}$ & Viúvo & Advogado & Católica & $\begin{array}{l}\text { Alfabetizado } \\
\text { (superior) }\end{array}$ & $\begin{array}{l}\text { Peniten- } \\
\text { ciária do } \\
\text { Estado, } \\
\text { SP }\end{array}$ & $\begin{array}{l}27 / 08 / 1916 \text { e } \\
31 / 07 / 1926\end{array}$ & $1 / 8 / 1922$ & $\begin{array}{l}\text { Trans- } \\
\text { ferência } \\
\text { para a } \\
\text { peniten- } \\
\text { ciária }\end{array}$ & Fotografia & $\begin{array}{l}\text { Delírio siste- } \\
\text { matizado de } \\
\text { interpretaçãa, } \\
\text { paranoia. }\end{array}$ & $\begin{array}{l}\text { Réu (art. } \\
294 \text { do } \\
\text { Código } \\
\text { Penal), por } \\
\text { homicídio } \\
\text { contra } \\
\text { esposa. }\end{array}$ & $\begin{array}{l}\text { Nega-se a assinar o } \\
\text { nome, porém é colo- } \\
\text { cada junto à fotografia } \\
\text { uma frase assinada } \\
\text { por ele. }\end{array}$ \\
\hline DAP 310 & M.M.S.V. & M & 58 & Branca & $\begin{array}{l}\text { Portu- } \\
\text { guesa }\end{array}$ & & Casado & Pedreiro & & & $\begin{array}{l}\text { Limeira, } \\
\mathrm{SP}\end{array}$ & $10 / 6 / 1916$ & $12 / 18 / 1932$ & Óbito & Fotografia & $\begin{array}{l}\text { Síndrome } \\
\text { paranoide, com } \\
\text { delírio religioso }\end{array}$ & $\begin{array}{l}\text { Absolvido } \\
\text { (art. 294 } \\
\text { do Código } \\
\text { Penal); } \\
\text { homicídio. }\end{array}$ & $\begin{array}{l}\text { Cópia de partes do } \\
\text { auto. Não tem evolu- } \\
\text { ído após a entrada no } \\
\text { manicômio. "(...) Repete } \\
\text { longos trechos de obras } \\
\text { religiosas que já leu". } \\
\text { Assassinato uma } \\
\text { menina, durante sessão } \\
\text { espírita, estrangulan- } \\
\text { do-a para tirar o diabo } \\
\text { de seu corpo. }\end{array}$ \\
\hline DAP 246 & $\begin{array}{l}\text { J.F.S. } \\
\text { (vulgo } \\
\text { José } \\
\text { Miguel) }\end{array}$ & M & 38 & Branca & Brasileira & $\begin{array}{l}\text { Monte } \\
\text { Leão, } \\
\text { MG }\end{array}$ & Casado & Lavrador & & Analfabeto & Avaré, SP & $10 / 8 / 1916$ & 9/9/1931 & Óbito & Fotografia & $\begin{array}{l}\text { Demência pre- } \\
\text { coce, de forma } \\
\text { paranoide. }\end{array}$ & $\begin{array}{l}\text { Réu, por } \\
\text { agressão }\end{array}$ & $\begin{array}{l}\text { No inquérito policial, } \\
\text { consta que desferiu } \\
\text { pancada na cabeça da } \\
\text { vítima }\end{array}$ \\
\hline DAP 363 & s.S. & M & 50 & Preta & Brasileira & $\begin{array}{l}\text { Ara- } \\
\text { ras,SP }\end{array}$ & Casado & $\begin{array}{l}\text { Jorna- } \\
\text { leiro }\end{array}$ & & $\begin{array}{l}\text { Alfabetizado } \\
\text { (não lê cor- } \\
\text { retamente) }\end{array}$ & Araras, SP & $12 / 16 / 1916$ & & & Fotografia & Débil mental & $\begin{array}{l}\text { Réu. Feriu } \\
\text { com um } \\
\text { facão o } \\
\text { patrão e a } \\
\text { filha dele. }\end{array}$ & $\begin{array}{l}\text { Cópia de partes do } \\
\text { processo criminal. }\end{array}$ \\
\hline
\end{tabular}




\begin{tabular}{|c|c|c|c|c|c|c|c|c|c|c|c|c|c|c|c|c|c|c|}
\hline 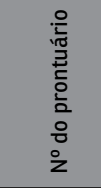 & 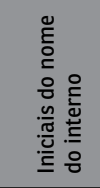 & ֻัे & 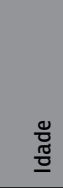 & ¿̀ & $\begin{array}{l}\frac{8}{\pi} \\
\frac{\pi}{\pi} \\
\frac{\pi}{\pi} \\
\frac{0}{0} \\
\frac{\pi}{2} \\
\frac{\pi}{2}\end{array}$ & 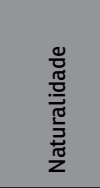 & 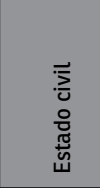 & 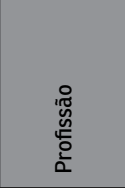 & $\frac{10}{\square}$ & 悹 & 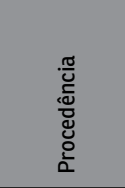 & 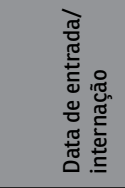 & $\begin{array}{l}\frac{\pi}{\pi} \\
\tilde{N} \\
0 \\
0 \\
\frac{\pi}{\pi} \\
0\end{array}$ & 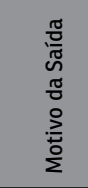 & 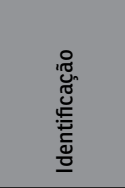 & 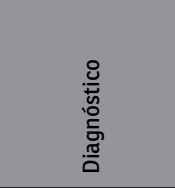 & 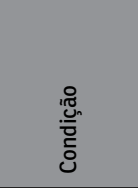 & 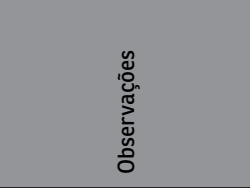 \\
\hline DAP 230 & J.A. & M & 19 & Preta & Brasileira & & Solteiro & $\begin{array}{l}\text { Traba- } \\
\text { lhador da } \\
\text { lavoura }\end{array}$ & & $\begin{array}{l}\text { Analfabeto } \\
\text { (nunca este- } \\
\text { ve na escola) }\end{array}$ & $\begin{array}{l}\text { São João } \\
\text { da Boa } \\
\text { Vista, SP }\end{array}$ & $12 / 29 / 1916$ & 5/13/1937 & Óbito & Fotografia & Loucura moral & $\begin{array}{l}\text { Réu (art. } \\
294 \text { do } \\
\text { Código } \\
\text { Penal), por } \\
\text { homicídio. }\end{array}$ & $\begin{array}{l}\text { Contém necropsia. } \\
\text { Cópia de partes do } \\
\text { processo criminal. } \\
\text { Acusado do assassinato } \\
\text { de uma moça. }\end{array}$ \\
\hline DAP 019 & A.P.S. & M & 67 & Branca & Brasileira & & Viúvo & Lavrador & Católica & Analfabeto & $\begin{array}{l}\text { Cadeia } \\
\text { Pública } \\
\text { de Iguape, } \\
\text { SP }\end{array}$ & 3/7/1917 & & & Fotografia & $\begin{array}{l}\text { Depressão } \\
\text { melancólica e } \\
\text { demência }\end{array}$ & $\begin{array}{l}\text { Réu (art. } \\
294 \text { do } \\
\text { Código } \\
\text { Penal), por } \\
\text { homicídio. }\end{array}$ & $\begin{array}{l}\text { Assassinato da cunha- } \\
\text { da, com arma de fogo, } \\
\text { por motivo desconheci- } \\
\text { do. Atacou o irmáo com } \\
\text { um machado. Cópia do } \\
\text { processo criminal. }\end{array}$ \\
\hline DAP 146 & F.F. & M & 25 & Branca & Brasileira & & Casado & Sapateiro & Católica & & $\begin{array}{l}\text { Peniten- } \\
\text { ciária do } \\
\text { Estado, } \\
\text { SP }\end{array}$ & 3/16/1917 & 5/12/1917 & Cura & Fotografia & Normal & $\begin{array}{l}\text { Réu, por } \\
\text { furto e } \\
\text { falsificação } \\
\text { de moeda. }\end{array}$ & Tatuagens. \\
\hline DAP 100 & c.S. & M & 49 & Branca & Italiana & Itália & Viúvo & Colono & & & Jaú, SP & 3/20/1917 & $12 / 27 / 1947$ & Óbito & Fotografia & Parafrenia & $\begin{array}{l}\text { Réu (art. } \\
294 \text { do } \\
\text { Código } \\
\text { Penal). }\end{array}$ & \\
\hline DAP 204 & J.F.C. & M & 53 & Preta & Brasileira & $\begin{array}{l}\text { Franca, } \\
\text { SP }\end{array}$ & Casado & & & & Avaré, SP & 4/2/1917 & $11 / 1 / 1931$ & Óbito & Fotografia & $\begin{array}{l}\text { Estado hipoma- } \\
\text { níaco }\end{array}$ & $\begin{array}{l}\text { Réu (art. } \\
294 \text { do } \\
\text { Código } \\
\text { Penal). }\end{array}$ & $\begin{array}{l}\text { Condenado a seis anos } \\
\text { de prisãa, sem infor- } \\
\text { maçāo sobre o motivo. } \\
\text { No prontuário, constam } \\
\text { duas procedências: } \\
\text { Avaré e Campos Novos } \\
\text { de Paranapanema. } \\
\text { Atestado de óbito. }\end{array}$ \\
\hline DAP 175 & H.H. & M & 28 & Branca & Síria & Síria & Solteiro & Mascate & Católica & & $\begin{array}{l}\text { Peniten- } \\
\text { ciária do } \\
\text { Estado, } \\
\text { SP }\end{array}$ & $5 / 2 / 1917$ & & & Fotografia & $\begin{array}{l}\text { Surto epilép- } \\
\text { tico, humor } \\
\text { reservado. }\end{array}$ & Réu & $\begin{array}{l}\text { Condenado a } 17 \text { anos } \\
\text { de prisão. Preso, sofreu } \\
\text { um surto epiléptico, } \\
\text { mas os médicos não } \\
\text { confirmam a vera- } \\
\text { cidade do fato. } 0 \\
\text { diagnóstico foi prejudi- } \\
\text { cado por ele não falar } \\
\text { português. }\end{array}$ \\
\hline DAP334 & P.R. & M & 20 & Branca & Brasileira & & Solteiro & & & & $\begin{array}{l}\text { Instituto } \\
\text { Disciplinar }\end{array}$ & 5/11/1917 & 6/10/1917 & $\begin{array}{l}\text { Não } \\
\text { curado }\end{array}$ & Fotografia & $\begin{array}{l}\text { Imbecilidade, } \\
\text { epilepsia, } \\
\text { convulsōes. }\end{array}$ & Réu & \\
\hline DAP 283 & L.A. & M & 28 & Preta & Brasileira & & Casado & Lavrador & & Analfabeto & Itu, SP & $5 / 22 / 1917$ & & & Fotografia & $\begin{array}{l}\text { Débil mental. } \\
\text { Convulsōes na } \\
\text { infância, síflis } \\
\text { na vida adulta. }\end{array}$ & Homicídio & $\begin{array}{l}\text { Matou o sogro a } \\
\text { cacetadas, pois este } \\
\text { era visto como culpado } \\
\text { pela desunião do casal. }\end{array}$ \\
\hline
\end{tabular}




\begin{tabular}{|c|c|c|c|c|c|c|c|c|c|c|c|c|c|c|c|c|c|c|}
\hline 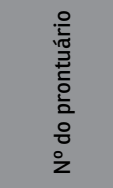 & 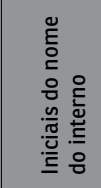 & ঙ̊̀̆ & $\begin{array}{l}\frac{8}{\pi} \\
\text { 疍 }\end{array}$ & ¿̀ & $\begin{array}{l}\frac{\pi}{\pi} \\
\frac{\pi}{\pi} \\
\frac{\pi}{\pi} \\
\frac{0}{\pi} \\
\frac{\pi}{2}\end{array}$ & $\begin{array}{l}\frac{8}{\pi} \\
\frac{\pi}{5} \\
\frac{\pi}{\pi} \\
\frac{\pi}{2} \\
\frac{\pi}{2}\end{array}$ & 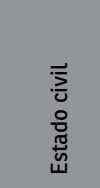 & 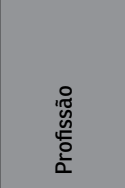 & 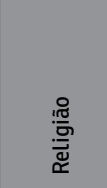 & 悹 & 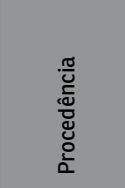 & 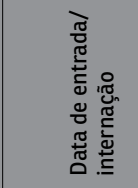 & 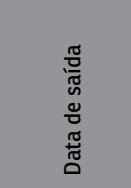 & 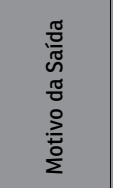 & 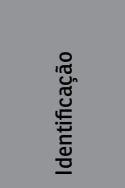 & 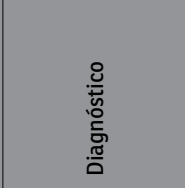 & 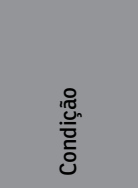 & 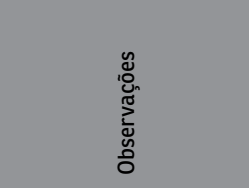 \\
\hline DAP 261 & J.M. & M & 31 & Preta & Brasileira & & Casado & Lavrador & Católica & Analfabeto & $\begin{array}{l}\text { Capivari, } \\
\text { SP }\end{array}$ & 6/25/1917 & & & Fotografia & $\begin{array}{l}\text { Epilepsia } \\
\text { impulsiva. Sa- } \\
\text { rampo e varióla } \\
\text { na infância }\end{array}$ & $\begin{array}{l}\text { Réu (art. } \\
302 \text { do } \\
\text { Código } \\
\text { Penal). }\end{array}$ & $\begin{array}{l}\text { Há cópia do processo } \\
\text { criminal. Agrediu um } \\
\text { soldado e seu amigo, } \\
\text { na própria casa. }\end{array}$ \\
\hline DAP 351 & P.S. & M & 34 & Parda & Brasileira & & Solteiro & & & & $\begin{array}{l}\text { Peniten- } \\
\text { ciária do } \\
\text { Estado, } \\
\text { SP }\end{array}$ & 6/26/1917 & & & Fotografia & $\begin{array}{l}\text { Não sofre das } \\
\text { faculdades } \\
\text { mentais }\end{array}$ & Réu & \\
\hline DAP 142 & E.S. & M & 35 & Branca & $\begin{array}{l}\text { Portu- } \\
\text { guesa }\end{array}$ & Portugal & Viúvo & & & $\begin{array}{l}\text { Analfabeto } \\
\text { (não sabe } \\
\text { ler) }\end{array}$ & $\begin{array}{l}\text { São Paulo, } \\
\text { SP }\end{array}$ & 6/29/1917 & & & Fotografia & $\begin{array}{l}\text { Degenerado, } \\
\text { imbecil. }\end{array}$ & Réu & $\begin{array}{l}\text { Teve sarampo e varíola } \\
\text { na infância. Há cópia } \\
\text { do processo criminal. }\end{array}$ \\
\hline DAP 138 & E.M. & M & 38 & Branca & Brasileira & & Solteiro & $\begin{array}{l}\text { Empre- } \\
\text { gado do } \\
\text { comércio }\end{array}$ & Católica & Alfabetizado & $\begin{array}{l}\text { São Paulo, } \\
\text { SP }\end{array}$ & 7/5/1917 & & & Fotografia & & $\begin{array}{l}\text { Contraban- } \\
\text { do de joias }\end{array}$ & $\begin{array}{l}\text { Pediu para ser levado } \\
\text { ao manicômio, pois } \\
\text { sofria agressōes na } \\
\text { prisão. }\end{array}$ \\
\hline DAP 049 & A.B. & M & 24 & Preta & Brasileira & & Solteiro & Lavrador & Católica & & $\begin{array}{l}\text { Peniten- } \\
\text { ciária do } \\
\text { Estado, } \\
\text { SP }\end{array}$ & 8/4/1917 & & & Fotografia & $\begin{array}{l}\text { Imbecil, alco- } \\
\text { olista }\end{array}$ & $\begin{array}{l}\text { Réu, por } \\
\text { homicídio. }\end{array}$ & \\
\hline DAP 117 & C.P. & M & 21 & Branca & Italiana & Itália & Solteiro & $\begin{array}{l}\text { Carro- } \\
\text { ceiro }\end{array}$ & Católica & & $\begin{array}{l}\text { São Paulo, } \\
\text { SP }\end{array}$ & $12 / 11 / 1917$ & & & Fotografia & & $\begin{array}{l}\text { Réu, por } \\
\text { furto. }\end{array}$ & \\
\hline DAP 031 & A.R.C. & M & 28 & Branca & Brasileira & & Casado & Lavrador & Católica & & Iguape, SP & $12 / 11 / 1917$ & 2/2/1932 & $\begin{array}{l}\text { Trans- } \\
\text { ferência } \\
\text { para o } \\
\text { Hospital } \\
\text { do Ju- } \\
\text { query } \\
\end{array}$ & Fotografia & $\begin{array}{l}\text { Alienaçāo } \\
\text { mental }\end{array}$ & $\begin{array}{l}\text { Réu, por } \\
\text { homicídio. }\end{array}$ & \\
\hline DAP 005 & A.C. & M & 30 & Branca & Italiana & Itália & Solteiro & Padeiro & Católica & Alfabetizado & $\begin{array}{l}\text { Peniten- } \\
\text { ciária do } \\
\text { Estado, } \\
\text { SP }\end{array}$ & $12 / 13 / 1917$ & & & Fotografia & $\begin{array}{l}\text { Demência } \\
\text { causada pela } \\
\text { sífilis }\end{array}$ & $\begin{array}{l}\text { Réu, crime } \\
\text { de furto; } \\
\text { condenado } \\
\text { a } 3 \text { anos. }\end{array}$ & $\begin{array}{l}\text { Tentativa de fuga do } \\
\text { manicômio. Tem medo } \\
\text { de morrer. }\end{array}$ \\
\hline DAP 173 & G.W.G. & M & 40 & Branca & Espanhola & & Casado & & & & $\begin{array}{l}\text { Jabotica- } \\
\text { bal, SP }\end{array}$ & $12 / 16 / 1917$ & & & Fotografia & $\begin{array}{l}\text { Síndrome } \\
\text { paranoica }\end{array}$ & Réu & Alegava ser perseguido. \\
\hline DAP 115 & C.T. & M & 62 & Branca & Italiana & Itália & Casado & Colono & Católica & & $\begin{array}{l}\text { Espírito } \\
\text { Santo do } \\
\text { Pinhal, SP }\end{array}$ & $12 / 25 / 1917$ & $1 / 3 / 1920$ & Óbito & & $\begin{array}{l}\text { Demência ate- } \\
\text { rosclerótica }\end{array}$ & $\begin{array}{l}\text { Réu, por } \\
\text { homicídio } \\
\text { do irmão. }\end{array}$ & \\
\hline DAP 061 & B.B. & M & 29 & Branca & Italiana & Itália & Casado & $\begin{array}{l}\text { Vendedor } \\
\text { ambu- } \\
\text { lante }\end{array}$ & Católica & & $\begin{array}{l}\text { São Paulo, } \\
\text { SP }\end{array}$ & $12 / 25 / 1917$ & $12 / 12 / 1956$ & $\begin{array}{l}\text { Trans- } \\
\text { ferência } \\
\text { para o } \\
\text { Hospital } \\
\text { do Ju- } \\
\text { query }\end{array}$ & Fotografia & $\begin{array}{l}\text { Síndrome } \\
\text { paranoica, } \\
\text { esquizofrenia. }\end{array}$ & & \\
\hline
\end{tabular}




\begin{tabular}{|c|c|c|c|c|c|c|c|c|c|c|c|c|c|c|c|c|c|c|}
\hline 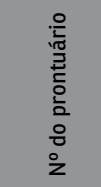 & 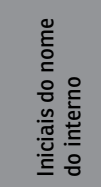 & 离 & $\begin{array}{l}\frac{\pi}{\pi} \\
\frac{\pi}{0}\end{array}$ & ¿̀ & $\begin{array}{l}\frac{\pi}{\pi} \\
\frac{\pi}{\pi} \\
\frac{\pi}{\pi} \\
\frac{0}{0} \\
\frac{\pi}{2} \\
\frac{\pi}{2}\end{array}$ & 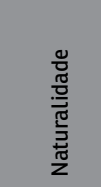 & 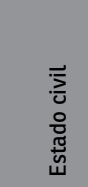 & 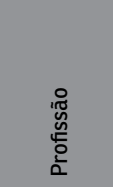 & 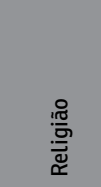 & 窵 & 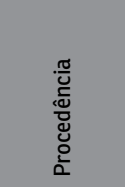 & 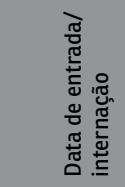 & 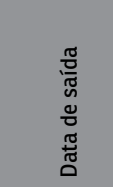 & 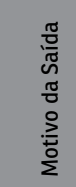 & 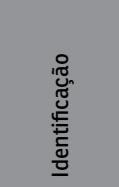 & 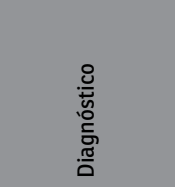 & 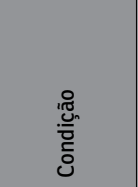 & 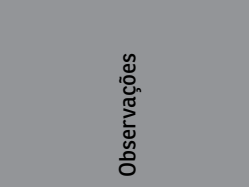 \\
\hline DAP 022 & A.K. & M & 36 & Branca & Turca & Turquia & Casado & $\begin{array}{l}\text { Comer- } \\
\text { ciante }\end{array}$ & & & $\begin{array}{l}\text { Peniten- } \\
\text { ciária do } \\
\text { Estado, } \\
\text { SP }\end{array}$ & $1 / 13 / 1918$ & & & Fotografia & $\begin{array}{l}\text { Degenerado, } \\
\text { claustrofobia. }\end{array}$ & $\begin{array}{l}\text { Réu, por } \\
\text { estelionato. }\end{array}$ & $\begin{array}{l}\text { Preso por não pagar } \\
\text { uma dívida. Boa noção } \\
\text { de tempo e meio. Não } \\
\text { apresenta delírios. } \\
\text { Sofre de claustrofobia. } \\
\text { Alega não ser louco. } \\
\text { Apresenta receio de } \\
\text { voltar à penitenciária. } \\
\text { Era trancado em uma } \\
\text { sala, e observado, para } \\
\text { "vencer" a claustro- } \\
\text { fobia. }\end{array}$ \\
\hline DAP 245 & J.F.M. & M & 25 & Parda & Brasileira & & Viúvo & Roceiro & Católica & & & $1 / 17 / 1918$ & & & Fotografia & $\begin{array}{l}\text { Esquizofrenia, } \\
\text { síflis. }\end{array}$ & $\begin{array}{l}\text { Réu, por } \\
\text { homicídio } \\
\text { contra a } \\
\text { esposa. }\end{array}$ & $\begin{array}{l}\text { Noção de tempo e meio } \\
\text { aproximada. Insiste que } \\
\text { não cometeu homicídio. }\end{array}$ \\
\hline DAP 110 & C.B. & M & & Branca & & & & & & & $\begin{array}{l}\text { Limeira, } \\
\text { SP }\end{array}$ & $1 / 25 / 1918$ & $7 / 1 / 1940$ & Óbito & $\begin{array}{l}\text { Fotogra- } \\
\text { fia. }\end{array}$ & $\begin{array}{l}\text { Síndrome me- } \\
\text { lancólica. Apá- } \\
\text { tico. Depressão } \\
\text { melancólica. } \\
\text { Degenerado } \\
\text { alcoólico. Ano- } \\
\text { malias fisicas. }\end{array}$ & $\begin{array}{l}\text { Réu (art. } \\
294, \$ 11^{\circ} \text { e } \\
\text { dupla- } \\
\text { mente no } \\
\text { art. } 303 \\
\text { do Código } \\
\text { Penal). } \\
\text { Absolvido. }\end{array}$ & $\begin{array}{l}\text { Não tem boa noção de } \\
\text { tempo e meio. Humor } \\
\text { reservado e tristonho, }\end{array}$ \\
\hline DAP 191 & J.A. & M & 47 & Branca & Italiana & Itália & Casado & Carroceiro & Católica & Analfabeto & $\begin{array}{l}\text { São Paulo, } \\
\text { SP }\end{array}$ & $2 / 26 / 1918$ & & & Fotografia & & & $\begin{array}{l}\text { Não há diagnóstico, } \\
\text { processo crime ou } \\
\text { exames. A única } \\
\text { informaçāo sobre o } \\
\text { interno é uma pequena } \\
\text { descrição sobre o dia } \\
\text { de sua saída da peni- } \\
\text { tenciária. Aguardava a } \\
\text { soltura e o encontro de } \\
\text { sua família, quando foi } \\
\text { acometido por um mal } \\
\text { estar e uma crise de } \\
\text { suor. Foi avaliado como } \\
\text { louco e enviado ao } \\
\text { manicômio, onde nāo } \\
\text { voltou a manifestar os } \\
\text { sintomas. }\end{array}$ \\
\hline DAP 124 & D.B. & M & 59 & Branca & Italiana & Itália & Casado & Canteiro & Católica & & $\begin{array}{l}\text { Piracaia, } \\
\text { SP }\end{array}$ & $3 / 13 / 1918$ & & & Fotografia & $\begin{array}{l}\text { Melancolia } \\
\text { sem delíio, } \\
\text { degenerado } \\
\text { semialcoolista, } \\
\text { alucinaçōes } \\
\text { psicomotoras. }\end{array}$ & $\begin{array}{l}\text { Réu, por } \\
\text { homicídio. }\end{array}$ & $\begin{array}{l}\text { Tem noção de tempo } \\
\text { e espaço. Medidas } \\
\text { corporais e descriçōes } \\
\text { de anomalias fisicas. }\end{array}$ \\
\hline
\end{tabular}




\begin{tabular}{|c|c|c|c|c|c|c|c|c|c|c|c|c|c|c|c|c|c|c|}
\hline 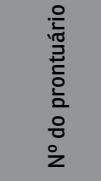 & 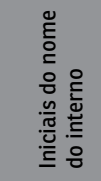 & ڤั̀ & $\begin{array}{l}\frac{\pi}{\pi} \\
\text { 元 }\end{array}$ & ¿̀ & $\begin{array}{l}\frac{8}{\pi} \\
\frac{\pi}{0} \\
\frac{\pi}{\pi} \\
\frac{0}{0} \\
\frac{\pi}{2} \\
\frac{\pi}{2}\end{array}$ & 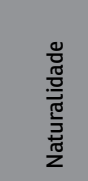 & 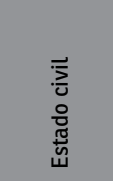 & 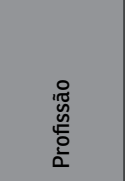 & : & 悹 & 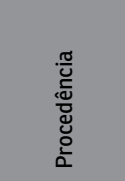 & 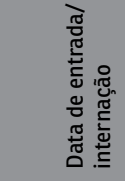 & 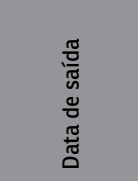 & 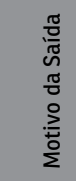 & 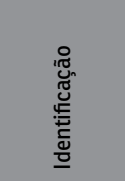 & 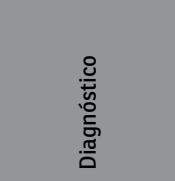 & 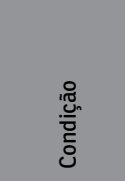 & 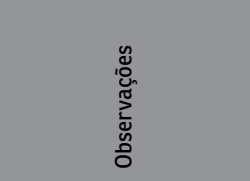 \\
\hline DAP 014 & A.B.P. & M & 45 & Branca & Brasileira & & Ignorado & Nenhuma & Ignorada & & $\begin{array}{l}\text { Instituto } \\
\text { Correcio- } \\
\text { nal }\end{array}$ & 3/18/1918 & & & Fotografia & Luppemania & $\begin{array}{l}\text { Vagabun- } \\
\text { dagem }\end{array}$ & $\begin{array}{l}\text { No "Lugar para autó- } \\
\text { grafo", há relato do } \\
\text { interno sobre receios e } \\
\text { dores físicas. Dores no } \\
\text { estômago efalta de ar. } \\
\text { Dizia que essas dores } \\
\text { tirariam o ar de seus } \\
\text { pulmōes e o levariam } \\
\text { à morte por asfixia. } \\
\text { Caráter deprimente, } \\
\text { tristeza e angústia. }\end{array}$ \\
\hline DAP 076 & B.A.S. & M & 46 & Preta & Brasileira & $\begin{array}{l}\text { Santa } \\
\text { Branca, } \\
\text { SP }\end{array}$ & Casado & $\begin{array}{l}\text { Operário } \\
\text { agrícola }\end{array}$ & Católica & & $\begin{array}{l}\text { Santa Rita } \\
\text { do Passa } \\
\text { Quatro, } \\
\text { SP }\end{array}$ & 3/18/1918 & $5 / 18 / 1937$ & Óbito & Fotografia & $\begin{array}{l}\text { Síndrome } \\
\text { paranoide, alu- } \\
\text { cinaçōes audi- } \\
\text { tivas e reaçōes } \\
\text { demoradas. }\end{array}$ & $\begin{array}{l}\text { Art. 303, } \\
\text { absolvido } \\
\text { do art. } \\
27, \$ 4^{\circ} \\
\text { do Código } \\
\text { Penal. }\end{array}$ & $\begin{array}{l}\text { Alega ver espíritos e } \\
\text { ouvir vozes na cadeaia. } \\
\text { Regularmente orienta- } \\
\text { do no espaço e tempo. } \\
\text { Afirma ter participado } \\
\text { da Grande Guerra, } \\
\text { nomeado general pelo } \\
\text { próprio Venceslau. }\end{array}$ \\
\hline DAP 101 & C.J.S. & M & 42 & $\begin{array}{l}\text { Branca } \\
\text { / parda }\end{array}$ & Brasileira & & Casado & $\begin{array}{l}\text { Cama- } \\
\text { rada }\end{array}$ & Católica & $\begin{array}{l}\text { Alfabetizado } \\
\text { (rudimentar) }\end{array}$ & $\begin{array}{l}\text { São Paulo, } \\
\text { SP }\end{array}$ & 3/27/1918 & & & Fotografia & $\begin{array}{l}\text { Síndrome para- } \\
\text { noide, delírios } \\
\text { de perseguição. }\end{array}$ & Réu & $\begin{array}{l}\text { Noção de tempo e } \\
\text { espaço exata. }\end{array}$ \\
\hline DAP 291 & M.A. & M & 24 & Branca & Brasileira & & Solteiro & & & Alfabetizado & $\begin{array}{l}\text { Jabotica- } \\
\text { bal, SP }\end{array}$ & 4/27/1918 & $12 / 29 / 1945$ & Óbito & $\begin{array}{l}\text { Fotografia } \\
\text { e digitais }\end{array}$ & $\begin{array}{l}\text { Demência } \\
\text { precoce }\end{array}$ & $\begin{array}{l}\text { Réu, por } \\
\text { homicídio } \\
\text { contra a } \\
\text { mãe. }\end{array}$ & $\begin{array}{l}\text { Desorientado no tempo } \\
\text { e espaço, afirmava ter } \\
\text { que "cortar a escravi- } \\
\text { dão da humanidade"; } \\
\text { sendo impedido pela } \\
\text { mãe/madrasta, ma- } \\
\text { tou-a com uma foice. } \\
\text { Fora preso como louco } \\
\text { em Araraquara. Seu } \\
\text { irmaã teve o mesmo } \\
\text { diagnóstico. }\end{array}$ \\
\hline DAP 340 & P.B. & M & 26 & Branca & Brasileira & & Ignorado & & & Analfabeto & $\begin{array}{l}\text { Bebedou- } \\
\text { ro, SP }\end{array}$ & 6/17/1918 & & & Fotografia & Imbecilidade & Réu & $\begin{array}{l}\text { Não tem noçāo de tem- } \\
\text { po e meio, imaginaçāo } \\
\text { insuficiente. Os médi- } \\
\text { cos afirmaram não ser } \\
\text { possível diagnosticar } \\
\text { qualquer delírio. Por se } \\
\text { tratar de criminoso, é } \\
\text { possivel que ainda não } \\
\text { tenha se manifestado. }\end{array}$ \\
\hline DAP 271 & J.V.B. & M & 23 & Branca & Brasileira & & Viúvo & & & & $\begin{array}{l}\text { Mogi das } \\
\text { Cruzes, } \\
\text { SP }\end{array}$ & $7 / 22 / 1918$ & & & Fotografia & $\begin{array}{l}\text { Delírios de } \\
\text { ilusão e perse- } \\
\text { cutório }\end{array}$ & $\begin{array}{l}\text { Réu, por } \\
\text { homicídio } \\
\text { contra } \\
\text { esposa. }\end{array}$ & $\begin{array}{l}\text { Não tem noção de } \\
\text { tempo e meio. Afirma } \\
\text { ser Cristo, vê animais } \\
\text { e "fala, algumas vezes, } \\
\text { em pecado". Preocu- } \\
\text { pação com o estado de } \\
\text { humor. }\end{array}$ \\
\hline
\end{tabular}




\begin{tabular}{|c|c|c|c|c|c|c|c|c|c|c|c|c|c|c|c|c|c|c|}
\hline 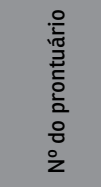 & 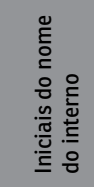 & 今̊̀ & $\begin{array}{l}\frac{\pi}{\pi} \\
\text { 五 }\end{array}$ & $\bar{u}$ & 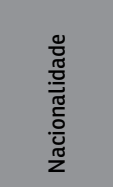 & 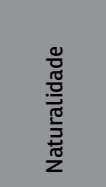 & 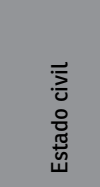 & 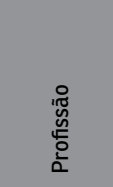 & : & 悹 & 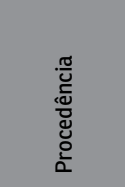 & 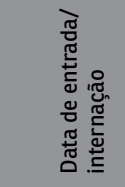 & 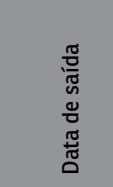 & 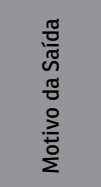 & 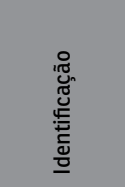 & 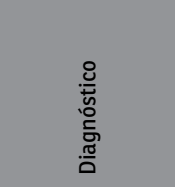 & 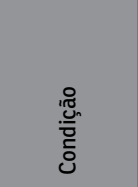 & 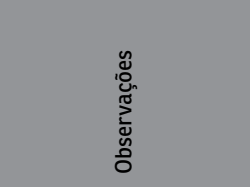 \\
\hline DAP 229 & J.L. (T.) & M & 18 & Branca & $\begin{array}{l}\text { Portu- } \\
\text { guesa }\end{array}$ & Portugal & Solteiro & $\begin{array}{l}\text { Empre- } \\
\text { gado de } \\
\text { hotel }\end{array}$ & Católica & & $\begin{array}{l}\text { São Paulo, } \\
\text { SP }\end{array}$ & 7/23/1918 & & & Fotografia & Epilepsia & $\begin{array}{l}\text { Réu, por } \\
\text { homicídio } \\
\text { contra } \\
\text { noiva. }\end{array}$ & $\begin{array}{l}\text { "Apresenta diversos } \\
\text { estigmas físicos de } \\
\text { degeneraçāo, tais como } \\
\text { assimetria craniana, } \\
\text { orelhas sésseis, úvula } \\
\text { inclinada para a es- } \\
\text { querda e ligeiro desvio } \\
\text { da comissura labial do } \\
\text { mesmo lado". Não de- } \\
\text { monstrou perturbaçōes } \\
\text { psíquicas. }\end{array}$ \\
\hline DAP 024 & A.A. & M & 47 & Branca & Italiana & Itália & Casado & Colono & Católica & Alfabetizado & $\begin{array}{l}\text { Rio Claro, } \\
\text { SP }\end{array}$ & 7/27/1918 & & & Fotografia & $\begin{array}{l}\text { Demência para- } \\
\text { noide, delírios } \\
\text { de perseguição. }\end{array}$ & $\begin{array}{l}\text { Réu, por } \\
\text { homicídio. }\end{array}$ & $\begin{array}{l}\text { Noção de tempo e meio } \\
\text { imperfeita. Conta o } \\
\text { tempo a seu modo. } \\
\text { Afirma que conhece a } \\
\text { todo o mundo. Alega } \\
\text { perseguido na colônia } \\
\text { onde vivia e trabalhava, } \\
\text { por isso matou a tiros } \\
\text { uma dessas pessoas. }\end{array}$ \\
\hline DAP 287 & $\begin{array}{l}\text { L.F. } \\
\text { (vulgo } \\
\text { Luiz do } \\
\text { Roque) }\end{array}$ & M & 22 & Branca & Brasileira & & Solteiro & Lavrador & & Analfabeto & $\begin{array}{l}\text { Descalva- } \\
\text { do, SP }\end{array}$ & 8/16/1918 & 2/2/1932 & $\begin{array}{l}\text { Trans- } \\
\text { ferência } \\
\text { para o } \\
\text { Hospital } \\
\text { do Ju- } \\
\text { query }\end{array}$ & Fotografia & $\begin{array}{l}\text { Imbecilida- } \\
\text { de, ilusōes, } \\
\text { alucinaçōes } \\
\text { e delírios de } \\
\text { perseguiçāo. } \\
\text { Um tipo } \\
\text { lombrosiano, } \\
\text { débil mental, } \\
\text { degenerado e } \\
\text { cínico. }\end{array}$ & $\begin{array}{l}\text { Réu, por } \\
\text { homicídio } \\
\text { contra o } \\
\text { cunhado. }\end{array}$ & $\begin{array}{l}\text { Dolicocéfalo, face as- } \\
\text { simétrica, grossos tre- } \\
\text { mores da língua, úvula } \\
\text { desviada à esquerda e } \\
\text { sensibilidade dolorosa. } \\
\text { Apresenta boa noção de } \\
\text { tempo e meio. }\end{array}$ \\
\hline DAP 225 & J.P.D. & M & 23 & Preta & Brasileira & & Casado & Carreiro & Católica & & Franca, SP & 9/16/1918 & & & Fotografia & $\begin{array}{l}\text { Delírio paranoi- } \\
\text { de persecutó- } \\
\text { rio, alucinaçōes } \\
\text { auditivas e } \\
\text { visuais. }\end{array}$ & $\begin{array}{l}\text { Réu, por } \\
\text { tentativa de } \\
\text { homicídio. }\end{array}$ & $\begin{array}{l}\text { Pai alcoolista, irmão } \\
\text { idiota e paralítico. } \\
\text { Sarampo e varicela na } \\
\text { infância. Adulto, bebia } \\
\text { e era "quase um men- } \\
\text { digo". Noçāo de tempo } \\
\text { e meio incompleta, } \\
\text { depressivo e propenso } \\
\text { ao choro. "Perde-se } \\
\text { (...) em intermináveis } \\
\text { divagaçōes". }\end{array}$ \\
\hline
\end{tabular}




\begin{tabular}{|c|c|c|c|c|c|c|c|c|c|c|c|c|c|c|c|c|c|c|}
\hline 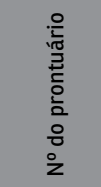 & 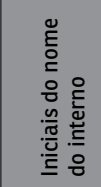 & §ั̀ & 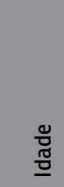 & ¿̀ & 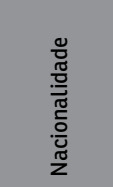 & 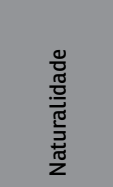 & 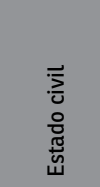 & 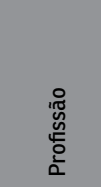 & $\frac{10}{\square}$ & 空 & 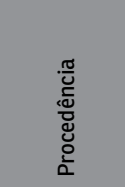 & 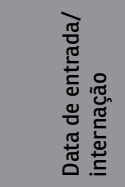 & 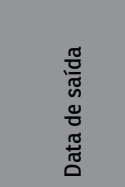 & 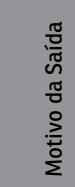 & 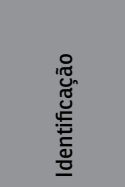 & 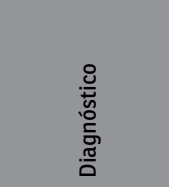 & 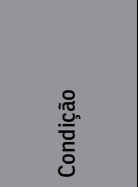 & 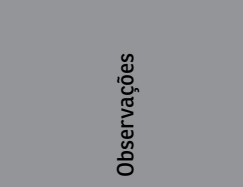 \\
\hline DAP 313 & N.G. & M & 18 & Branca & Italiana & & Solteiro & Operário & & $\begin{array}{l}\text { Alfabetizado } \\
\text { (afirma } \\
\text { saber escre- } \\
\text { ver) }\end{array}$ & $\begin{array}{l}\text { Peniten- } \\
\text { ciária do } \\
\text { Estado, } \\
\text { SP }\end{array}$ & $10 / 12 / 1918$ & & & Fotografia & $\begin{array}{l}\text { Psicose de } \\
\text { involuçāo, } \\
\text { delíros de } \\
\text { perseguição, } \\
\text { "confusão de } \\
\text { espírito". }\end{array}$ & Réu & $\begin{array}{l}\text { Tipo facial ariano. } \\
\text { Reservado, mal-hu- } \\
\text { morado, nāo gosta de } \\
\text { ser interrogado. Tem } \\
\text { noçāo de sua reclusão e } \\
\text { pede liberdade, dizendo } \\
\text { não ter motivos para } \\
\text { estar ali. Descrito como } \\
\text { irritado. }\end{array}$ \\
\hline DAP 166 & F.R.S.F. & M & 45 & Branca & Brasileira & $\begin{array}{l}\text { Serra Ne- } \\
\text { gra, SP }\end{array}$ & Casado & Serrador & & Analfabeto & $\begin{array}{l}\text { Instituto } \\
\text { Corre- } \\
\text { cional de } \\
\text { Taubaté, } \\
\text { SP }\end{array}$ & $10 / 18 / 1918$ & $3 / 19 / 1933$ & Óbito & Fotografia & $\begin{array}{l}\text { Esquizofrenia, } \\
\text { alucinaçōes } \\
\text { visuais e audi- } \\
\text { tivas. }\end{array}$ & $\begin{array}{l}\text { Condenado } \\
\text { a reclusão } \\
\text { de } 3 \\
\text { anos, por } \\
\text { "inveterada } \\
\text { vagabun- } \\
\text { dagem } \\
\text { a que se } \\
\text { entregou, } \\
\text { além da ir- } \\
\text { regularida- } \\
\text { de de seus } \\
\text { costumes". }\end{array}$ & $\begin{array}{l}\text { Tuberculose pulmonar. } \\
\text { Alega ver moças de } \\
\text { branco, às quais neces- } \\
\text { sita entreter, pois ficam } \\
\text { deitadas em seu leito } \\
\text { por horas. }\end{array}$ \\
\hline DAP 183 & J.B.O. & M & 30 & $\begin{array}{l}\text { Cabo- } \\
\text { cla }\end{array}$ & Brasileira & & Casado & Roceiro & Católica & & $\begin{array}{l}\text { São Paulo, } \\
\text { SP }\end{array}$ & $11 / 15 / 1918$ & $6 / 2 / 1944$ & Óbito & $\begin{array}{l}\text { Fotogra- } \\
\text { fia. }\end{array}$ & $\begin{array}{l}\text { Demência } \\
\text { precoce, esqui- } \\
\text { zofrenia. }\end{array}$ & $\begin{array}{l}\text { Réu, por } \\
\text { tentativa } \\
\text { de homicí- } \\
\text { dio contra } \\
\text { a esposa } \\
\text { e a mãe, e } \\
\text { homicídio } \\
\text { da filha a } \\
\text { pauladas. }\end{array}$ & $\begin{array}{l}\text { Internado para } \\
\text { exame de sanidade } \\
\text { mental. Desorientado } \\
\text { alopsiquicamente, } \\
\text { "incapaz de rememorar } \\
\text { fatos passados, pois } \\
\text { a atenção desviada } \\
\text { o impossibilita desse } \\
\text { esforço mnemônico". }\end{array}$ \\
\hline DAP 141 & E.M.O. & $\mathrm{F}$ & 28 & Branca & Brasileira & & Casada & & & Analfabeta & $\begin{array}{l}\text { Orlândia, } \\
\text { SP }\end{array}$ & 4/12/1919 & $7 / 29 / 1927$ & Alta & Fotografia & $\begin{array}{l}\text { Confusão men- } \\
\text { tal delirante }\end{array}$ & $\begin{array}{l}\text { Ré. por } \\
\text { homicídio } \\
\text { contra o } \\
\text { pai. }\end{array}$ & $\begin{array}{l}\text { Segundo a mãe, sua fi- } \\
\text { lha vinha apresentando } \\
\text { sintomas de alienação } \\
\text { mental e manifestando } \\
\text { ódio contra ela e seu } \\
\text { pai. }\end{array}$ \\
\hline DAP 039 & A.M.C. & $\mathrm{F}$ & 22 & Parda & Brasileira & & Solteira & & & & $\begin{array}{l}\text { São Paulo, } \\
\text { SP }\end{array}$ & $6 / 6 / 1919$ & & & Fotografia & $\begin{array}{l}\text { Demência pre- } \\
\text { coce catatônica }\end{array}$ & Ré & \\
\hline
\end{tabular}




\begin{tabular}{|c|c|c|c|c|c|c|c|c|c|c|c|c|c|c|c|c|c|c|}
\hline 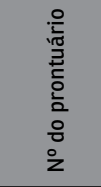 & 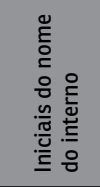 & 离 & $\begin{array}{l}\frac{8}{\tilde{\sigma}} \\
\frac{\pi}{0}\end{array}$ & ¿̀ & 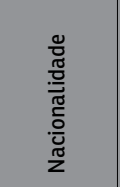 & 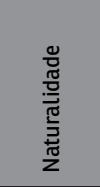 & 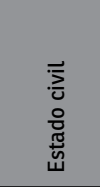 & 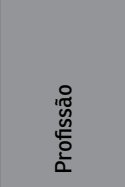 & : & 悹 & 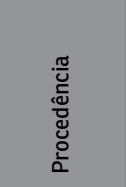 & 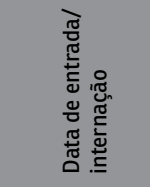 & 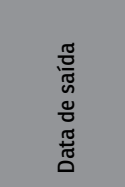 & 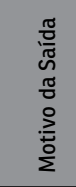 & 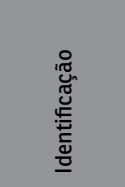 & 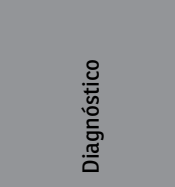 & 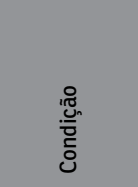 & 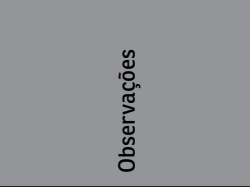 \\
\hline DAP 280 & L.F. & M & 29 & Branca & Italiana & Itália & Solteiro & $\begin{array}{l}\text { Carro- } \\
\text { ceiro }\end{array}$ & Católica & & $\begin{array}{l}\text { Ribeirão } \\
\text { Preto, SP }\end{array}$ & 6/8/1919 & & & Fotografia & $\begin{array}{l}\text { Não apresenta } \\
\text { doença mental. } \\
\text { Alcoólatra } \\
\text { crônico }\end{array}$ & Réu & $\begin{array}{l}\text { Segundo testemunhas, } \\
\text { o réu encontrava-se } \\
\text { alcoolizado ao cometer } \\
\text { o crime. }\end{array}$ \\
\hline DAP 354 & R.H.N. & M & 40 & Branca & Síria & Síria & Casado & $\begin{array}{l}\text { Nego- } \\
\text { ciante }\end{array}$ & Grega & & $\begin{array}{l}\text { São Paulo, } \\
\text { SP }\end{array}$ & $\begin{array}{l}01 / 10 / 1916 \text { e } \\
13 / 06 / 1919\end{array}$ & $12 / 26 / 1935$ & Óbito & Fotografia & $\begin{array}{l}\text { Síndrome } \\
\text { paranoide }\end{array}$ & Réu & $\begin{array}{l}\text { Internado por soli- } \\
\text { citação do juiz das } \\
\text { Execuçōes Criminais } \\
\text { da Capital. Transfe- } \\
\text { rido para o serviço } \\
\text { cirúrgico do Hospital } \\
\text { Central, por apresentar } \\
\text { grave afecçāo na face } \\
\text { posterior do tórax, de } \\
\text { natureza desconhecida. } \\
\text { Óbito por septicemia. }\end{array}$ \\
\hline DAP 174 & G.G.O. & $\mathrm{F}$ & 30 & Branca & Brasileira & $\begin{array}{l}\text { Taubaté, } \\
\text { SP }\end{array}$ & Viúva & $\begin{array}{l}\text { Serviços } \\
\text { domésti- } \\
\text { cos }\end{array}$ & & Analfabeta & $\begin{array}{l}\text { Agudos, } \\
\text { SP }\end{array}$ & 6/14/1919 & 3/19/1924 & Óbito & Fotografia & $\begin{array}{l}\text { Síndrome } \\
\text { paranoide }\end{array}$ & $\begin{array}{l}\text { Ré, por } \\
\text { homicídio } \\
\text { contra o } \\
\text { marido. } \\
\end{array}$ & \\
\hline DAP 015 & A.C. & M & 30 & Branca & Italiana & & Casado & & & & $\begin{array}{l}\text { São Paulo, } \\
\text { SP }\end{array}$ & 6/29/1919 & & & Fotografia & & Réu & $\begin{array}{l}\text { Expōe-se apenas a } \\
\text { situação que poderia } \\
\text { acarretar o crime. }\end{array}$ \\
\hline DAP 037 & O.M. & M & 20 & Branca & Brasileira & & Solteiro & & & Alfabetizado & $\begin{array}{l}\text { Rio Preto, } \\
\text { SP }\end{array}$ & 7/1/1919 & & & Fotografia & $\begin{array}{l}\text { Degenerado, } \\
\text { epilético. }\end{array}$ & $\begin{array}{l}\text { Réu, por } \\
\text { homicííio } \\
\text { contra a } \\
\text { noiva, por } \\
\text { ela ter re- } \\
\text { cusado seu } \\
\text { pedido de } \\
\text { casamento. }\end{array}$ & $\begin{array}{l}\text { Cópia do processo } \\
\text { criminal. Ascendentes } \\
\text { diretos e colaterais com } \\
\text { fatores degenerativos, } \\
\text { como alcoolismo e } \\
\text { síflis. Divergência } \\
\text { sobre a nacionalidade } \\
\text { (brasileira ou italiana). }\end{array}$ \\
\hline DAP 382 & T.B.M. & M & 26 & Preta & Brasileira & & Casado & $\begin{array}{l}\text { Soldado } \\
\text { de polícia }\end{array}$ & Católica & & $\begin{array}{l}\text { Cadeia } \\
\text { Pública da } \\
\text { Capital, } \\
\text { SP }\end{array}$ & $7 / 2 / 1919$ & 9/17/1959 & Óbito & Fotografia & $\begin{array}{l}\text { Esquizofrenia } \\
\text { crônica, delírio } \\
\text { místico e mega- } \\
\text { lomania }\end{array}$ & $\begin{array}{l}\text { Réu, por } \\
\text { homicídio } \\
\text { contra a } \\
\text { esposa. }\end{array}$ & $\begin{array}{l}\text { Hérnia escrotal, porém } \\
\text { não fez cirurgiai. Em } \\
1952 \text {, há possibilida- } \\
\text { de de remoçāo para } \\
\text { hospital psiquiátrico } \\
\text { comum. Sem alteração } \\
\text { do quadro, no período } \\
\text { em que ficou internado. } \\
\text { Nega ter cometido } \\
\text { homicídio. }\end{array}$ \\
\hline
\end{tabular}




\begin{tabular}{|c|c|c|c|c|c|c|c|c|c|c|c|c|c|c|c|c|c|c|}
\hline 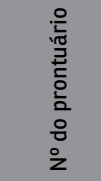 & 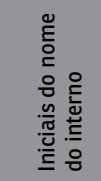 & ֻ̊̀̊̀ & $\begin{array}{l}\frac{\pi}{\pi} \\
\frac{\pi}{0}\end{array}$ & ò & $\begin{array}{l}\frac{\pi}{\pi} \\
\frac{\pi}{\pi} \\
\frac{\pi}{\pi} \\
\frac{0}{0} \\
\frac{\pi}{2} \\
\frac{\pi}{2}\end{array}$ & 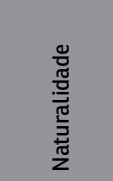 & 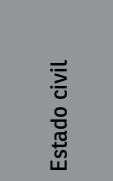 & 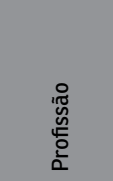 & : & 㝕 & 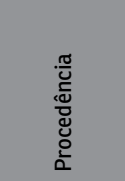 & 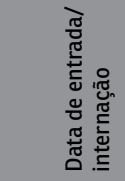 & $\begin{array}{l}\frac{\pi}{0} \\
\frac{0}{\pi} \\
0 \\
0 \\
\frac{\pi}{\pi} \\
0\end{array}$ & $\begin{array}{l}\frac{\pi}{0} \\
\frac{0}{0} \\
0 \\
\frac{\pi}{0} \\
0 \\
\stackrel{0}{0} \\
\sum\end{array}$ & 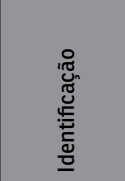 & 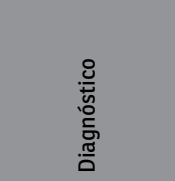 & 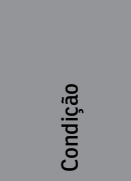 & 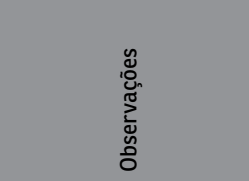 \\
\hline DAP 285 & L.F. & M & 22 & Branca & Brasileira & & Solteiro & $\begin{array}{l}\text { Soldado } \\
\text { de polícia }\end{array}$ & & & Itu, SP & $8 / 5 / 1919$ & & & Fotografia & $\begin{array}{l}\text { Não apresenta } \\
\text { doença mental }\end{array}$ & $\begin{array}{l}\text { Réu, por } \\
\text { homicídio } \\
\text { contra um } \\
\text { indivíduo } \\
\text { que resistiu } \\
\text { à sua voz } \\
\text { de prisão e } \\
\text { o agrediu a } \\
\text { pancadas. }\end{array}$ & $\begin{array}{l}\text { Cópia de partes do } \\
\text { processo criminal }\end{array}$ \\
\hline DAP 270 & J.T. & M & 15 & Branca & Espanhola & $\begin{array}{l}\text { Tenerife, } \\
\text { Espanha }\end{array}$ & Solteiro & $\begin{array}{l}\text { Jorna- } \\
\text { leiro }\end{array}$ & & Analfabeto & $\begin{array}{l}\text { Espírito } \\
\text { Santo do } \\
\text { Pinhal, SP }\end{array}$ & 8/7/1919 & $2 / 2 / 1932$ & $\begin{array}{l}\text { Trans- } \\
\text { ferência } \\
\text { para o } \\
\text { Hospital } \\
\text { do Ju- } \\
\text { query }\end{array}$ & Fotografia & $\begin{array}{l}\text { Demência pre- } \\
\text { coce, caráter } \\
\text { irresponsável. }\end{array}$ & $\begin{array}{l}\text { Réu (art. } \\
294 \text { do } \\
\text { Código } \\
\text { Penal), por } \\
\text { homicídio } \\
\text { contra um } \\
\text { compa- } \\
\text { nheiro de } \\
\text { trabalho. }\end{array}$ & $\begin{array}{l}\text { Cópia do processo cri- } \\
\text { minal. Menor internado } \\
\text { para exame mental. }\end{array}$ \\
\hline DAP 217 & J.R. & M & 24 & Branca & $\begin{array}{l}\text { Portu- } \\
\text { guesa }\end{array}$ & Portugal & Solteiro & Lavrador & & & $\begin{array}{l}\text { Peniten- } \\
\text { ciária do } \\
\text { Estado, } \\
\text { SP }\end{array}$ & 8/8/1919 & & & Fotografia & $\begin{array}{l}\text { Alucinaçōes } \\
\text { visuais e } \\
\text { auditivas }\end{array}$ & & $\begin{array}{l}\text { Divergências quanto ao } \\
\text { nome do interno. }\end{array}$ \\
\hline DAP 080 & B.B. & M & 46 & Branca & Espanhola & $\begin{array}{l}\text { Ithas } \\
\text { Baleares, } \\
\text { Espanha }\end{array}$ & Casado & & & Alfabetizado & $\begin{array}{l}\text { Peniten- } \\
\text { ciária do } \\
\text { Estado, } \\
\text { SP }\end{array}$ & $8 / 29 / 1919$ & $11 / 20 / 1919$ & $\begin{array}{l}\text { Trans- } \\
\text { ferência } \\
\text { para a } \\
\text { Peniten- } \\
\text { ciária do } \\
\text { Estado }\end{array}$ & Fotografia & $\begin{array}{l}\text { Não apresenta } \\
\text { doença mental }\end{array}$ & $\begin{array}{l}\text { Senten- } \\
\text { ciado a } 20 \\
\text { anos, por } \\
\text { crime não } \\
\text { informado }\end{array}$ & $\begin{array}{l}\text { Durante sua perma- } \\
\text { nência, não apresentou } \\
\text { distúrbio mental. }\end{array}$ \\
\hline DAP 088 & B.C. & M & 35 & Branca & Brasileira & $\begin{array}{l}\text { Taubaté, } \\
\text { SP }\end{array}$ & Ignorado & $\begin{array}{l}\text { Traba- } \\
\text { lhador da } \\
\text { lavoura }\end{array}$ & & & & 9/4/1919 & & & Fotografia & Epilepsia & Réu & $\begin{array}{l}\text { Histórico de epilepsia } \\
\text { na família. }\end{array}$ \\
\hline DAP 375 & S.N. & M & 30 & Branca & Brasileira & & Viúvo & $\begin{array}{l}\text { Empre- } \\
\text { gado de } \\
\text { escritório }\end{array}$ & Católica & & Iguape, SP & 9/20/1919 & $1 / 27 / 1932$ & Óbito & Fotografia & $\begin{array}{l}\text { Paralisia geral, } \\
\text { enfraquecimen- } \\
\text { to especial de } \\
\text { memória. }\end{array}$ & $\begin{array}{l}\text { Réu, por } \\
\text { homicídio } \\
\text { contra a } \\
\text { esposa. }\end{array}$ & $\begin{array}{l}\text { Cópias de partes do } \\
\text { processo criminal. } \\
\text { Recorte de jornal. } \\
\text { Internado para exame } \\
\text { de sanidade, a pedido } \\
\text { do Ministério Público } \\
\text { e da defesa. Óbito por } \\
\text { febre tif́́ide. }\end{array}$ \\
\hline DAP 327 & O.R. & M & 21 & Branca & Italiana & & Solteiro & & & & $\begin{array}{l}\text { Peniten- } \\
\text { ciária do } \\
\text { Estado, } \\
\text { SP }\end{array}$ & 9/23/1919 & & $\begin{array}{l}\text { Trans- } \\
\text { ferência } \\
\text { para a } \\
\text { Peniten- } \\
\text { ciária do } \\
\text { Estado }\end{array}$ & Fotografia & $\begin{array}{l}\text { Não apresenta } \\
\text { doença mental }\end{array}$ & & $\begin{array}{l}\text { Durante sua permanên- } \\
\text { cia, não apresentava } \\
\text { distúrbio mental }\end{array}$ \\
\hline
\end{tabular}




\begin{tabular}{|c|c|c|c|c|c|c|c|c|c|c|c|c|c|c|c|c|c|c|}
\hline 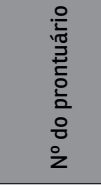 & 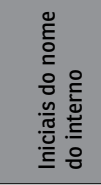 & ֻั̊ & $\begin{array}{l}\frac{8}{0} \\
\text { 西 }\end{array}$ & ¿̀ & $\begin{array}{l}\frac{0}{\pi} \\
\frac{\pi}{0} \\
\frac{0}{\pi} \\
\frac{5}{0} \\
\frac{0}{2} \\
\frac{\pi}{2}\end{array}$ & $\begin{array}{l}\frac{2}{\pi} \\
\frac{\pi}{0} \\
\frac{\pi}{50} \\
\frac{\pi}{2} \\
\frac{\pi}{2}\end{array}$ & 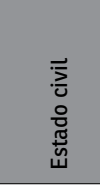 & 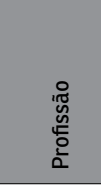 & $\begin{array}{l}\frac{0}{\pi} \\
\frac{10}{\pi} \\
\frac{\pi}{\pi}\end{array}$ & 突 & 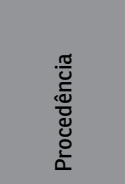 & 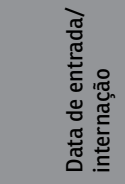 & $\begin{array}{l}\frac{\pi}{\pi} \\
\frac{\pi}{\pi} \\
0 \\
0 \\
\frac{\pi}{\pi} \\
0\end{array}$ & 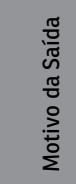 & 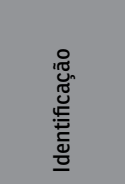 & 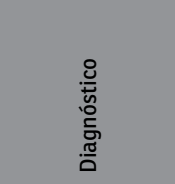 & 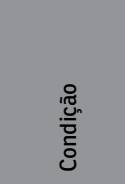 & 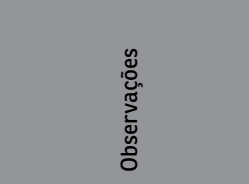 \\
\hline DAP 23 & A.G. & M & 27 & Branca & Brasileira & & Solteiro & & & Alfabetizado & $\begin{array}{l}\text { Peniten- } \\
\text { ciária do } \\
\text { Estado, } \\
\text { SP }\end{array}$ & $10 / 24 / 1919$ & & & Fotografia & $\begin{array}{l}\text { Psicopatia } \\
\text { constitucio- } \\
\text { nal, ideias de } \\
\text { perseguição } \\
\text { e episódios } \\
\text { delirantes. }\end{array}$ & $\begin{array}{l}\text { Senten- } \\
\text { ciado por } \\
\text { homicídio. }\end{array}$ & $\begin{array}{l}\text { Era inteligente, seus } \\
\text { estudos foram provei- } \\
\text { tosos e, quem lê o que } \\
\text { ele escreve, presume } \\
\text { ser fruto de cursos } \\
\text { regulares e longos. } \\
\end{array}$ \\
\hline DAP 181 & J.T.D. & M & 32 & Branca & Espanhola & & Solteiro & & & & $\begin{array}{l}\text { Peniten- } \\
\text { ciária do } \\
\text { Estado, } \\
\text { SP }\end{array}$ & $11 / 28 / 1919$ & & & Fotografia & $\begin{array}{l}\text { Não sofre das } \\
\text { faculdades } \\
\text { mentais }\end{array}$ & $\begin{array}{l}\text { Senten- } \\
\text { ciado por } \\
\text { homicídio. }\end{array}$ & $\begin{array}{l}\text { Transferido para o } \\
\text { Manicômio Judiciário } \\
\text { devido às agressōes } \\
\text { cometidas contra o car- } \\
\text { cereiro da penitenciária }\end{array}$ \\
\hline DAP 133 & E.F.S. & M & 39 & Preta & Brasileira & & Solteiro & Pedreiro & Católica & Alfabetizado & $\begin{array}{l}\text { Cadeia } \\
\text { Pública da } \\
\text { Capital, } \\
\text { SP, SP }\end{array}$ & $12 / 23 / 1919$ & & & Fotografia & $\begin{array}{l}\text { Delírio crônico } \\
\text { de perseguição }\end{array}$ & Réu & $\begin{array}{l}\text { Agredira o vigário da } \\
\text { Consolacacaoo, por julgar } \\
\text { que usava palavras } \\
\text { que inutilizavam as } \\
\text { açōes milagrosas de } \\
\text { uma oraçãa que fazia. } \\
\text { Submetido a exame de } \\
\text { sanidade mental. }\end{array}$ \\
\hline DAP 391 & V.D.R. & M & 27 & Branca & Italiana & & Solteiro & & Católica & & $\begin{array}{l}\text { São Paulo, } \\
\text { SP }\end{array}$ & $1 / 11 / 1920$ & & & Fotografia & $\begin{array}{l}\text { Demência pre- } \\
\text { coce catatônica, } \\
\text { autismo }\end{array}$ & & $\begin{array}{l}\text { Prática de movimen- } \\
\text { tos repetitivos. Não } \\
\text { demonstra o que sente. } \\
\text { Postura entorpecida e } \\
\text { diferente, olhar vago. }\end{array}$ \\
\hline DAP 326 & O.L.M. & M & 24 & Branca & Brasileira & & Solteiro & $\begin{array}{l}\text { Funcio- } \\
\text { nário da } \\
\text { polícia }\end{array}$ & & & & 3/21/1920 & & & & $\begin{array}{l}\text { Compulsão } \\
\text { mental tóxica, } \\
\text { alucinaçōes } \\
\text { ocasionais, } \\
\text { usuário decla- } \\
\text { rado de drogas } \\
\text { e álcool. }\end{array}$ & & $\begin{array}{l}\text { Consumia cocaína } \\
\text { e éter. Flagrado em } \\
\text { crime de furto. }\end{array}$ \\
\hline DAP 254 & $\begin{array}{l}\text { J.J. } \\
\text { (vulgo } \\
\text { Joaquim } \\
\text { Baiano) }\end{array}$ & M & 38 & Parda & Brasileira & $\begin{array}{l}\text { Canabra- } \\
\text { va dos } \\
\text { Caldei- } \\
\text { ras, BA }\end{array}$ & Solteiro & $\begin{array}{l}\text { Jorna- } \\
\text { leiro }\end{array}$ & & Analfabeto & $\begin{array}{l}\text { Jabotica- } \\
\text { bal, SP }\end{array}$ & $3 / 26 / 1920$ & $6 / 4 / 1937$ & Óbito & Fotografia & Parafrenia & $\begin{array}{l}\text { Réu, por } \\
\text { homicídio } \\
\text { contra um } \\
\text { compa- } \\
\text { nheiro de } \\
\text { trabalho. }\end{array}$ & $\begin{array}{l}\text { Cópia de partes do } \\
\text { processo criminal. No- } \\
\text { meado como solteiro, } \\
\text { tinha uma amásia. }\end{array}$ \\
\hline
\end{tabular}




\begin{tabular}{|c|c|c|c|c|c|c|c|c|c|c|c|c|c|c|c|c|c|c|}
\hline 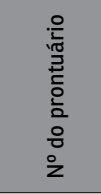 & 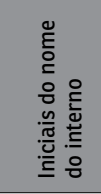 & ঙ̊̀̊ & 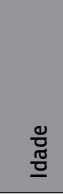 & ¿̀ & $\begin{array}{l}\frac{\pi}{\pi} \\
\frac{\pi}{\pi} \\
\frac{\pi}{\pi} \\
\frac{0}{0} \\
\frac{\pi}{2} \\
\frac{\pi}{2}\end{array}$ & 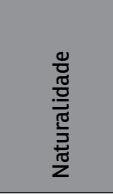 & 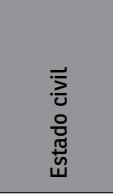 & 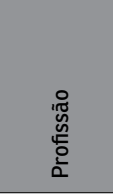 & 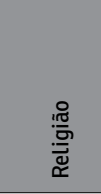 & 悹 & 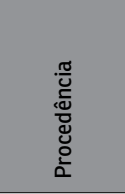 & 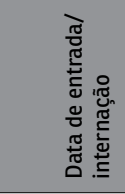 & 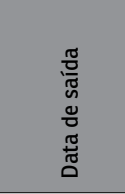 & 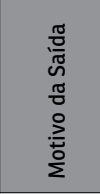 & 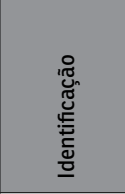 & 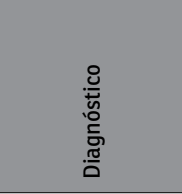 & 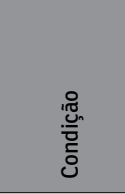 & 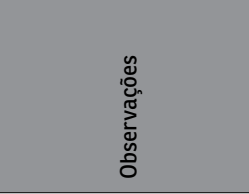 \\
\hline DAP 307 & M.A. & M & 19 & Branca & Francesa & & Solteiro & Colono & & Alfabetizado & $\begin{array}{l}\text { Bebedou- } \\
\text { ro, SP }\end{array}$ & $4 / 16 / 1920$ & & & $\begin{array}{l}\text { Fotografia } \\
\text { e medidas } \\
\text { corporais }\end{array}$ & $\begin{array}{l}\text { Delírios de } \\
\text { perseguição ou } \\
\text { epileptoides }\end{array}$ & $\begin{array}{l}\text { Réu,por } \\
\text { homicídio. }\end{array}$ & $\begin{array}{l}\text { Assassinara uma moça, } \\
\text { por esta "Lhe haver } \\
\text { posto um feitiço (...) } \\
\text { que só se anularia } \\
\text { depois da morte da } \\
\text { mesma". Boa noção de } \\
\text { tempo e espaço. Relata } \\
\text { ver o retrato de sua } \\
\text { vitima nas paredes e } \\
\text { no ar. }\end{array}$ \\
\hline DAP129 & D.V. & M & 44 & Branca & Italiana & & Ignorado & & & & $\begin{array}{l}\text { Taquari- } \\
\text { tinga, SP }\end{array}$ & 7/13/1920 & & & Fotografia & $\begin{array}{l}\text { Confusão } \\
\text { alucinatória } \\
\text { alcoólica aguda }\end{array}$ & $\begin{array}{l}\text { Réu, por } \\
\text { homicídio. }\end{array}$ & \\
\hline DAP 231 & J.A. & M & 27 & Branca & $\begin{array}{l}\text { Portu- } \\
\text { guesa }\end{array}$ & $\begin{array}{l}\text { Ilha da } \\
\text { Madeira, } \\
\text { Portugal }\end{array}$ & Solteiro & $\begin{array}{l}\text { Trabalha- } \\
\text { dor }\end{array}$ & Católica & Analfabeto & Santos, SP & $7 / 18 / 1920$ & 6/12/1957 & $\begin{array}{l}\text { Trans- } \\
\text { ferência } \\
\text { para o } \\
\text { Hospital } \\
\text { do Ju- } \\
\text { query }\end{array}$ & $\begin{array}{l}\text { Fotografia } \\
\text { e digitais }\end{array}$ & $\begin{array}{l}\text { Debilidade } \\
\text { mental e } \\
\text { alcoolismo, } \\
\text { oligofrenia. }\end{array}$ & $\begin{array}{l}\text { Réu, por } \\
\text { homicídio. }\end{array}$ & $\begin{array}{l}\text { Documento da vítima } \\
\text { decapitada e do ins- } \\
\text { trumento utilizado no } \\
\text { crime (foice). Segundo } \\
\text { o próprio interno, ele } \\
\text { teria sido aconselhado, } \\
\text { por uma voz sobrenatu- } \\
\text { ral, a cometer o crime. }\end{array}$ \\
\hline DAP 003 & A.R. & M & 57 & Branca & Italiana & & Solteiro & Colono & & Alfabetizado & $\begin{array}{l}\text { Jabotica- } \\
\text { bal, SP }\end{array}$ & $8 / 20 / 1920$ & $11 / 20 / 1920$ & & Fotografia & $\begin{array}{l}\text { Delírio alucina- } \\
\text { tório causado } \\
\text { por insolação } \\
\text { e agravado por } \\
\text { intoxicaçāa } \\
\text { etílica }\end{array}$ & Réu & \\
\hline DAP 259 & J.L.T. & M & 34 & Parda & Brasileira & & Casado & & Católica & & $\begin{array}{l}\text { Santa } \\
\text { Cruz do } \\
\text { Rio Pardo, } \\
\text { SP }\end{array}$ & $8 / 26 / 1920$ & $1 / 3 / 1935$ & Óbito & $\begin{array}{l}\text { Fotografia } \\
\text { e medidas } \\
\text { corporais }\end{array}$ & $\begin{array}{l}\text { Síndrome } \\
\text { paranoide }\end{array}$ & $\begin{array}{l}\text { Senten- } \\
\text { ciado a } 12 \\
\text { anos, por } \\
\text { ferir um } \\
\text { soldado } \\
\text { (art. 211, } \\
\$ 4^{\circ} \text { do } \\
\text { Código } \\
\text { Penal). }\end{array}$ & $\begin{array}{l}\text { Afirma que "inutilizar } \\
\text { um homem, prenden- } \\
\text { do-o como maluco é } \\
\text { crime maior que matá- } \\
\text {-lo". Morreu de colapso } \\
\text { cardíaco. Afirma ser } \\
\text { perseguido desde os } 2 \\
\text { anos de idade, podendo } \\
\text { provar, graças a marca } \\
\text { de bala em seu corpo. }\end{array}$ \\
\hline DAP 193 & J.B.C. & M & 28 & Branca & Brasileira & & Casado & $\begin{array}{l}\text { Jorna- } \\
\text { leiro }\end{array}$ & & & Bauru, SP & $8 / 31 / 1920$ & & & Fotografia & $\begin{array}{l}\text { Debilidade } \\
\text { mental, alcoo- } \\
\text { lismo }\end{array}$ & & \\
\hline
\end{tabular}




\begin{tabular}{|c|c|c|c|c|c|c|c|c|c|c|c|c|c|c|c|c|c|c|}
\hline 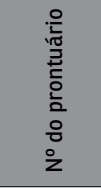 & 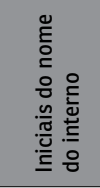 & $\stackrel{乛}{\mathscr{乛}}$ & 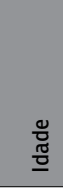 & ¿̀ & 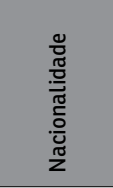 & $\begin{array}{l}\frac{\pi}{\pi} \\
\frac{\pi}{0} \\
\frac{\pi}{5} \\
\frac{\pi}{2} \\
\frac{\pi}{2}\end{array}$ & 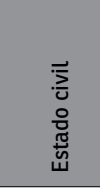 & 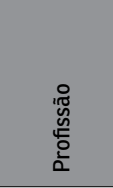 & 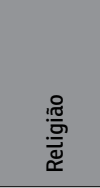 & 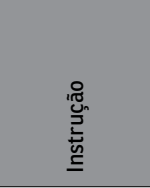 & 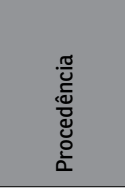 & 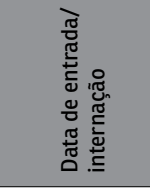 & 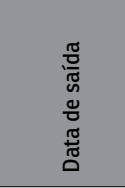 & 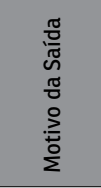 & 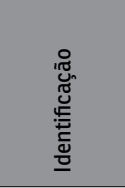 & 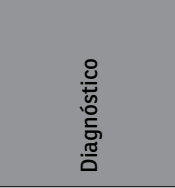 & 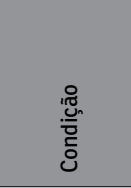 & 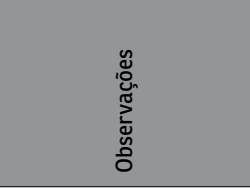 \\
\hline DAP 371 & S.S. & M & 22 & Preta & Brasileira & & Solteiro & $\begin{array}{l}\text { Jorna- } \\
\text { leiro }\end{array}$ & Católica & Analfabeto & $\begin{array}{l}\text { São Paulo, } \\
\text { SP }\end{array}$ & 9/2/1920 & & & $\begin{array}{l}\text { Fotografia } \\
\text { e medidas } \\
\text { corporais }\end{array}$ & & $\begin{array}{l}\text { Réu, por } \\
\text { homicídio. }\end{array}$ & $\begin{array}{l}\text { Boa noção de tempo e } \\
\text { espaço. }\end{array}$ \\
\hline DAP 034 & A.N. & M & 28 & Branca & Síria & Síria & Solteiro & Operário & Católica & Alfabetizado & $\begin{array}{l}\text { Peniten- } \\
\text { ciária do } \\
\text { Estado, } \\
\text { SP }\end{array}$ & $\begin{array}{l}17 / 09 / 1920 \text { e } \\
27 / 03 / 1923\end{array}$ & 9/21/1933 & Óbito & Fotografia & $\begin{array}{l}\text { Loucura manía- } \\
\text { co-depressiva }\end{array}$ & $\begin{array}{l}\text { Réu, por } \\
\text { furto e } \\
\text { falsificação } \\
\text { de moeda. }\end{array}$ & \\
\hline DAP 381 & T.N. & M & 26 & Parda & & & Solteiro & Operário & Católica & & & 9/24/1920 & & Óbito & $\begin{array}{l}\text { Medidas } \\
\text { corporais }\end{array}$ & & $\begin{array}{l}\text { Réu, por } \\
\text { agressāo. }\end{array}$ & $\begin{array}{l}\text { Cometera agressão } \\
\text { contra um companhei- } \\
\text { ro. Não foi diagnosti- } \\
\text { cado com perturbação } \\
\text { mental. }\end{array}$ \\
\hline DAP104 & C.A.C. & M & 37 & Branca & Brasileira & & Casado & $\begin{array}{l}\text { Jorna- } \\
\text { leiro }\end{array}$ & Católica & Alfabetizado & $\begin{array}{l}\text { Cadeia } \\
\text { Pública da } \\
\text { Capital, } \\
\text { SP }\end{array}$ & $10 / 24 / 1920$ & $5 / 6 / 1936$ & $\begin{array}{l}\text { Entre- } \\
\text { gue à } \\
\text { família }\end{array}$ & Fotografia & & Réu & $\begin{array}{l}\text { Cartas dos familiares, } \\
\text { pedindo notícias. Não } \\
\text { consta diagnóstico, } \\
\text { mas há um parecer em } \\
\text { que se inscreve "parece } \\
\text { tratar-se de um caso } \\
\text { de esquizofrenia". No } \\
\text { exame psíquico, o in- } \\
\text { terno afirma que estava } \\
\text { "encervejado", no ato } \\
\text { do crime. }\end{array}$ \\
\hline DAP 335 & P.A.C. & M & 37 & Branca & $\begin{array}{l}\text { Espa- } \\
\text { nhola }\end{array}$ & $\begin{array}{l}\text { Meira, } \\
\text { Espanha }\end{array}$ & Casado & Colono & Católica & $\begin{array}{l}\text { Alfabetizado } \\
\text { (rudimentar) }\end{array}$ & $\begin{array}{l}\text { Orlândia, } \\
\text { SP }\end{array}$ & $10 / 28 / 1920$ & $7 / 20 / 1946$ & Óbito & $\begin{array}{l}\text { Fotografia, } \\
\text { medidas } \\
\text { corporais } \\
\text { e digitais }\end{array}$ & $\begin{array}{l}\text { Síndrome } \\
\text { paranoide, per- } \\
\text { tubaçōes de ce- } \\
\text { nestesia, delírio } \\
\text { persecutório e } \\
\text { de grandeza, } \\
\text { distúrbios da } \\
\text { afetividade e } \\
\text { vontade. }\end{array}$ & $\begin{array}{l}\text { Senten- } \\
\text { ciado a } \\
14 \text { anos } \\
\text { (art. } 294 \\
\text { do Código } \\
\text { Penal). }\end{array}$ & $\begin{array}{l}\text { Boa noçāo de tempo } \\
\text { e espaço. Há cartas } \\
\text { da família pedindo } \\
\text { informaçōes. Afrmava } \\
\text { ser perseguido pelo } \\
\text { patrāo, que queria que } \\
\text { ele se casasse com } \\
\text { sua filha. O patrāo } \\
\text { rondava sua casa e ele } \\
\text { o matou "antes que me } \\
\text { matasse". }\end{array}$ \\
\hline DAP 197 & J.B. & M & 54 & Branca & Italiana & Itália & Viúvo & Sapateiro & Católica & Alfabetizado & $\begin{array}{l}\text { Taquari- } \\
\text { tinga, SP }\end{array}$ & $11 / 21 / 1920$ & $2 / 2 / 1932$ & $\begin{array}{l}\text { Trans- } \\
\text { ferência } \\
\text { para o } \\
\text { Hospital } \\
\text { do Ju- } \\
\text { query }\end{array}$ & Fotografia & Esquizofrenia & $\begin{array}{l}\text { Réu, por } \\
\text { homicídio. }\end{array}$ & $\begin{array}{l}\text { Cópia de partes do } \\
\text { processo criminal. Des- } \\
\text { feriu golpes de martelo } \\
\text { contra um companhei- } \\
\text { ro de trabalho. }\end{array}$ \\
\hline
\end{tabular}




\begin{tabular}{|c|c|c|c|c|c|c|c|c|c|c|c|c|c|c|c|c|c|c|}
\hline 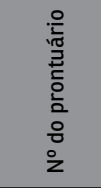 & 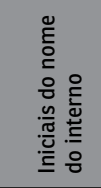 & ๙ั̀ & $\begin{array}{l}\frac{\pi}{\pi} \\
\frac{\pi}{2}\end{array}$ & ¿̀ & $\begin{array}{l}\frac{\pi}{\pi} \\
\frac{\pi}{\pi} \\
\frac{\pi}{\pi} \\
\frac{0}{0} \\
\frac{\pi}{z}\end{array}$ & 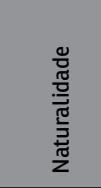 & 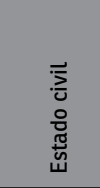 & 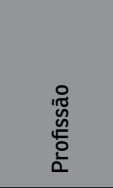 & $\frac{: 0}{\frac{\pi}{5}}$ & 空 & 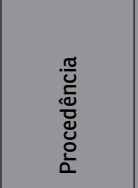 & 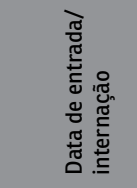 & $\begin{array}{l}\frac{\pi}{0} \\
\frac{\pi}{\pi} \\
0 \\
\frac{\pi}{\pi} \\
\frac{\pi}{0}\end{array}$ & 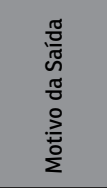 & 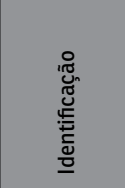 & 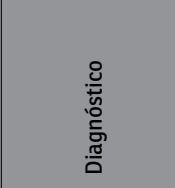 & 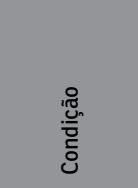 & 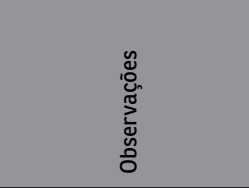 \\
\hline DAP 396 & V.B. & M & 36 & Branca & Italiana & $\begin{array}{l}\text { Verona, } \\
\text { Itália }\end{array}$ & Casado & Lavrador & & Analfabeto & Bariri, SP & $11 / 25 / 1920$ & & & $\begin{array}{l}\text { Fotografia } \\
\text { e medidas } \\
\text { corporais }\end{array}$ & $\begin{array}{l}\text { Epilepsia } \\
\text { psíquica }\end{array}$ & $\begin{array}{l}\text { Sentencia- } \\
\text { do (art. } 294 \\
\text { do Código } \\
\text { Penal), por } \\
\text { homicídio } \\
\text { de conhe- } \\
\text { cido. }\end{array}$ & $\begin{array}{l}\text { Cópia do processo } \\
\text { criminal. Boas noçōes } \\
\text { de tempo e espaço. }\end{array}$ \\
\hline DAP 179 & I.A.F. & M & 35 & Branca & Brasileira & & Solteiro & Roceiro & & Analfabeto & $\begin{array}{l}\text { Peniten- } \\
\text { ciária do } \\
\text { Estado, } \\
\text { SP }\end{array}$ & $11 / 25 / 1920$ & & $\begin{array}{l}\text { Trans- } \\
\text { ferência } \\
\text { para o } \\
\text { Hospital } \\
\text { do Ju- } \\
\text { query }\end{array}$ & & $\begin{array}{l}\text { Demência } \\
\text { precoce }\end{array}$ & $\begin{array}{l}\text { Senten- } \\
\text { ciado }\end{array}$ & $\begin{array}{l}\text { Embora conste ser } \\
\text { solteiro, era amasiado. } \\
\text { Há documentos que in- } \\
\text { formam sobre o crime } \\
\text { cometido. }\end{array}$ \\
\hline DAPI13 & C.M. & M & 35 & Branca & Italiana & & Casado & & Católica & Alfabetizado & $\begin{array}{l}\text { Cadeia } \\
\text { Pública da } \\
\text { Capital, } \\
\text { SP }\end{array}$ & $12 / 10 / 1920$ & & & Fotografia & $\begin{array}{l}\text { Esquizofrenia, } \\
\text { síndrome } \\
\text { paranoide. }\end{array}$ & $\begin{array}{l}\text { Réu por } \\
\text { homicídio }\end{array}$ & \\
\hline DAPl18 & D.C. & M & 29 & Branca & Brasileira & & Casado & Lavrador & Católica & Alfabetizado & $\begin{array}{l}\text { Comarca } \\
\text { de Casa } \\
\text { Branca, SP }\end{array}$ & $12 / 14 / 1920$ & & & & & Réu & $\begin{array}{l}\text { Produziu lesōes corpo- } \\
\text { rais, com um punhal, } \\
\text { em um comerciante } \\
\text { português, após dis- } \\
\text { cussão, quando ambos } \\
\text { estavam embriagados. }\end{array}$ \\
\hline DAP 296 & M. J. C. & $\mathrm{F}$ & 35 & Branca & Italiana & $\begin{array}{l}\text { Verona, } \\
\text { Itália }\end{array}$ & Casada & $\begin{array}{l}\text { Domés- } \\
\text { tica }\end{array}$ & & Analfabeta & $\begin{array}{l}\text { Descalva- } \\
\text { do, SP }\end{array}$ & $12 / 25 / 1920$ & & & $\begin{array}{l}\text { Fotografia, } \\
\text { medidas } \\
\text { corporais } \\
\text { e digitais }\end{array}$ & $\begin{array}{l}\text { Debilidade } \\
\text { mental }\end{array}$ & $\begin{array}{l}\text { Réu (art. } \\
294 \text { do } \\
\text { Código } \\
\text { Penal). por } \\
\text { infanticíio. } \\
\text { Absolvido. }\end{array}$ & $\begin{array}{l}\text { Treze irmāos. Matou } \\
\text { seu filho adulterino de } \\
9 \text { dias, afogando-o e } \\
\text { jogando-o em um rio. } \\
\text { Separada do marido } \\
\text { havia } 11 \text { anos. }\end{array}$ \\
\hline DAP 198 & J.C.I & M & 26 & Preta & Brasileira & & Solteiro & & Católica & & Cajuru, SP & $12 / 31 / 1920$ & & & Fotografia & $\begin{array}{l}\text { Demência } \\
\text { precoce, com } \\
\text { tendência } \\
\text { para a forma } \\
\text { catatônica. }\end{array}$ & Réu & \\
\hline DAP 099 & C.B. & M & 66 & Branca & Italiana & $\begin{array}{l}\text { Veneza, } \\
\text { Itália }\end{array}$ & Viúvo & Colono & & Alfabetizado & $\begin{array}{l}\text { Peniten- } \\
\text { ciária do } \\
\text { Estado, } \\
\text { SP }\end{array}$ & 2/17/1921 & & & Fotografia & $\begin{array}{l}\text { Alcoolismo, } \\
\text { demência }\end{array}$ & $\begin{array}{l}\text { Réu ,por } \\
\text { homicídio } \\
\text { contra a } \\
\text { esposa. } \\
\end{array}$ & \\
\hline DAP 315 & N.D. & M & 38 & Branca & Italiana & Itália & Viúvo & Lavrador & Católica & Alfabetizado & $\begin{array}{l}\text { Peniten- } \\
\text { ciária do } \\
\text { Estado, } \\
\text { SP }\end{array}$ & 2/17/1921 & & & & $\begin{array}{l}\text { Epilepsia } \\
\text { psíquica, débil } \\
\text { mental. }\end{array}$ & $\begin{array}{l}\text { Réu, por } \\
\text { homicídio } \\
\text { contra a } \\
\text { esposa. }\end{array}$ & $\begin{array}{l}\text { Após um desentendi- } \\
\text { mento com sua mulher, } \\
\text { matou-a a macha- } \\
\text { dadas. }\end{array}$ \\
\hline DAP 267 & J.N. & M & 32 & Branca & Síria & & Solteiro & Comércio & Católica & Alfabetizado & $\begin{array}{l}\text { Peniten- } \\
\text { ciária do } \\
\text { Estado, } \\
\text { SP }\end{array}$ & 2/17/1921 & & & & $\begin{array}{l}\text { Demência } \\
\text { precoce, } \\
\text { alucinaçōes de } \\
\text { perseguiçāo. }\end{array}$ & $\begin{array}{l}\text { Senten- } \\
\text { ciado a } 21 \\
\text { anos, por } \\
\text { homicídio. }\end{array}$ & \\
\hline
\end{tabular}




\begin{tabular}{|c|c|c|c|c|c|c|c|c|c|c|c|c|c|c|c|c|c|c|}
\hline 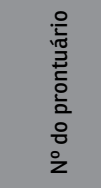 & 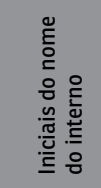 & §ั̀ & $\begin{array}{l}\frac{\pi}{\pi} \\
\text { 元 }\end{array}$ & ò & $\begin{array}{l}\frac{\pi}{\pi} \\
\frac{\pi}{\pi} \\
\frac{\pi}{\pi} \\
\frac{0}{0} \\
\frac{\pi}{2} \\
\frac{\pi}{2}\end{array}$ & 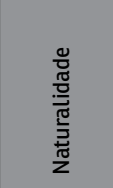 & 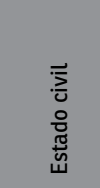 & 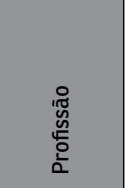 & 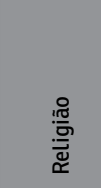 & 空 & 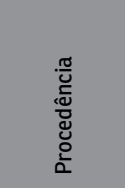 & 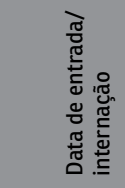 & $\begin{array}{l}\frac{\pi}{0} \\
\tilde{N} \\
0 \\
0 \\
\frac{\pi}{\pi} \\
0\end{array}$ & 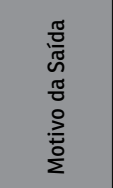 & 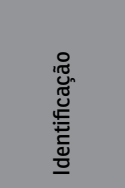 & 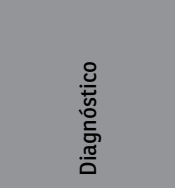 & 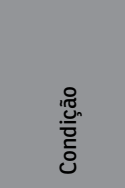 & 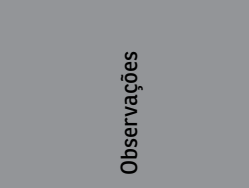 \\
\hline DAP 360 & R.S.O. & M & 36 & Preta & Brasileira & & Casado & & & & $\begin{array}{l}\text { Ribeirão } \\
\text { Preto, SP }\end{array}$ & $3 / 2 / 1921$ & & & & $\begin{array}{l}\text { Confusão men- } \\
\text { tal delirante }\end{array}$ & & \\
\hline DAP 006 & A.C. & M & 40 & Branca & Italiana & $\begin{array}{l}\text { Ancona, } \\
\text { Itália }\end{array}$ & Casado & Pedreiro & Católica & Alfabetizado & $\begin{array}{l}\text { São Paulo, } \\
\text { SP }\end{array}$ & $4 / 30 / 1921$ & & & Fotografia & & & $\begin{array}{l}\text { Sente dores de cabeça } \\
\text { e repuxamentos nos } \\
\text { músculos. Apresenta } \\
\text { alteraçōes "no terreno } \\
\text { da vontade e do cará- } \\
\text { ter". Busca descobrir } \\
\text { infidelidade da mulher, } \\
\text { pega sua arma e atira } \\
\text { no vizinho. }\end{array}$ \\
\hline DAP 265 & J.M. & M & 25 & Branca & Brasileira & & Solteiro & & Católica & & $\begin{array}{l}\text { Peniten- } \\
\text { ciária de } \\
\text { Araras }\end{array}$ & $4 / 30 / 1921$ & & $\begin{array}{l}\text { Trans- } \\
\text { ferência } \\
\text { para } \\
\text { hospício } \\
\text { comum }\end{array}$ & & $\begin{array}{l}\text { Debil mental, } \\
\text { alcoolista, es- } \\
\text { quizofrênico. }\end{array}$ & $\begin{array}{l}\text { Réu, por } \\
\text { homicídio. }\end{array}$ & $\begin{array}{l}\text { Matou um homem a } \\
\text { facadas. }\end{array}$ \\
\hline DAP 160 & F.M. & M & 32 & Branca & $\begin{array}{l}\text { Portu- } \\
\text { guesa }\end{array}$ & $\begin{array}{l}\text { Beira, } \\
\text { Portugal }\end{array}$ & Solteiro & Padeiro & Católica & & $\begin{array}{l}\text { Peniten- } \\
\text { ciária do } \\
\text { Estado, } \\
\text { SP }\end{array}$ & $5 / 6 / 1921$ & & & Fotografia & $\begin{array}{l}\text { Alcoolismo e } \\
\text { epilepsia }\end{array}$ & $\begin{array}{l}\text { Réu, por } \\
\text { homicídio } \\
\text { do patrão. }\end{array}$ & \\
\hline DAP 348 & $\begin{array}{l}\text { P.V.S. } \\
\text { (vulgo } \\
\text { Pedro } \\
\text { Cipó) }\end{array}$ & M & 45 & Preta & Brasileira & $\begin{array}{l}\text { Senhor } \\
\text { Bom } \\
\text { Jesus dos } \\
\text { Meiras, } \\
\text { BA }\end{array}$ & Solteiro & Lavrador & Católica & Analfabeto & $\begin{array}{l}\text { Peniten- } \\
\text { ciária do } \\
\text { Estado, } \\
\text { SP }\end{array}$ & $5 / 6 / 1921$ & $7 / 1 / 1927$ & & & Esquizofrenia & $\begin{array}{l}\text { Tentativa } \\
\text { de homi- } \\
\text { cídio do } \\
\text { vizinho. }\end{array}$ & $\begin{array}{l}\text { Fala sobre a seca da } \\
\text { Bahia e as migraçōes, } \\
\text { assim como expoé seus } \\
\text { conhecimentos sobre } \\
\text { Monarquia e República. } \\
\text { Pratica cultos sespíritas } \\
\text { na penitenciária, mes- } \\
\text { mo sendo católico. }\end{array}$ \\
\hline DAP 321 & O.L.S & M & 25 & Branca & Brasileira & & Casado & Lavrador & Católica & Alfabetizado & $\begin{array}{l}\text { Peniten- } \\
\text { ciária do } \\
\text { Estado, } \\
\text { SP }\end{array}$ & $5 / 6 / 1921$ & & $\begin{array}{l}\text { Trans- } \\
\text { ferência } \\
\text { para o } \\
\text { Hospital } \\
\text { do Ju- } \\
\text { query }\end{array}$ & & & $\begin{array}{l}\text { Réu, por } \\
\text { homicídio. }\end{array}$ & $\begin{array}{l}\text { Acusado de matar um } \\
\text { homem, em um jogo de } \\
\text { futebol, quando estava } \\
\text { embriagado. }\end{array}$ \\
\hline DAP 182 & J.D. & M & 40 & Branca & $\begin{array}{l}\text { Tchecos- } \\
\text {-lovaca }\end{array}$ & & Viúvo & Jardineiro & & & $\begin{array}{l}\text { São Paulo, } \\
\text { SP }\end{array}$ & $5 / 8 / 1921$ & $4 / 19 / 1945$ & Óbito & $\begin{array}{l}\text { Fotografia } \\
\text { e digitais }\end{array}$ & $\begin{array}{l}\text { Demência } \\
\text { precoce }\end{array}$ & $\begin{array}{l}\text { Réu, por } \\
\text { homicídio. }\end{array}$ & \\
\hline DAP 362 & S.F. & M & 38 & & Italiana & & Casado & $\begin{array}{l}\text { Comer- } \\
\text { ciante }\end{array}$ & & Alfabetizado & $\begin{array}{l}\text { Penitenci- } \\
\text { ária de Rio } \\
\text { Claro, SP }\end{array}$ & $6 / 24 / 1921$ & & & Fotografia & Melancolia & Réu & $\begin{array}{l}\text { Cópia de partes do } \\
\text { processo criminal. Em } \\
\text { defesa de sua esposa, } \\
\text { matou, a tiros, o dono } \\
\text { da casa que alugava. }\end{array}$ \\
\hline DAP 159 & F.M. & M & 40 & Branca & Italiana & & Casado & Colono & & & $\begin{array}{l}\text { São Paulo, } \\
\text { SP }\end{array}$ & $6 / 28 / 1921$ & & & Fotografia & & & $\begin{array}{l}\text { Bem associado no } \\
\text { tempo e espaço. Alega } \\
\text { uma lacuna quanto ao } \\
\text { motivo de sua prisão. }\end{array}$ \\
\hline
\end{tabular}




\begin{tabular}{|c|c|c|c|c|c|c|c|c|c|c|c|c|c|c|c|c|c|c|}
\hline 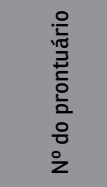 & 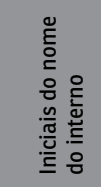 & ஓ̊̀. & 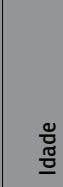 & ¿̀ & $\begin{array}{l}\frac{0}{\pi} \\
\frac{\pi}{\pi} \\
\frac{\pi}{\pi} \\
\frac{0}{\pi} \\
\frac{\pi}{2} \\
z\end{array}$ & 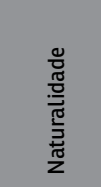 & 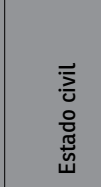 & 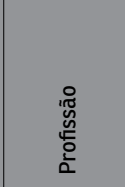 & 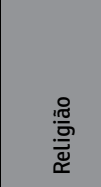 & 䒿 & 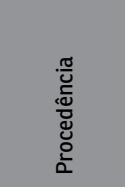 & 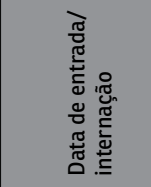 & 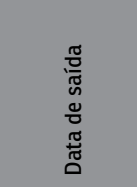 & 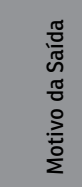 & 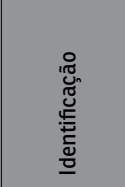 & 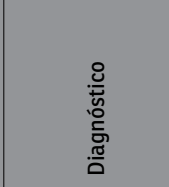 & 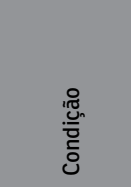 & 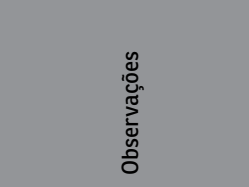 \\
\hline DAP 373 & S.C. & M & 50 & Parda & Brasileira & & Solteiro & $\begin{array}{l}\text { Carro- } \\
\text { ceiro }\end{array}$ & Católica & Analfabeto & $\begin{array}{l}\text { Peniten- } \\
\text { ciária do } \\
\text { Estado, } \\
\text { SP }\end{array}$ & $6 / 28 / 1921$ & $10 / 9 / 1931$ & & & $\begin{array}{l}\text { Debilidade } \\
\text { mental, } \\
\text { alcoolismo, } \\
\text { acessos de } \\
\text { compreensão } \\
\text { passageiros. }\end{array}$ & & $\begin{array}{l}\text { Vida desregrada, } \\
\text { sendo levado sempre } \\
\text { pelo álcool. Incidente } \\
\text { envolve a mulher com } \\
\text { quem estava. }\end{array}$ \\
\hline DAP 218 & J.R.B. & M & 29 & Branca & Brasileira & & Casado & $\begin{array}{l}\text { Trabalha- } \\
\text { dor rural }\end{array}$ & & Analfabeto & $\begin{array}{l}\text { São José } \\
\text { dos Cam- } \\
\text { pos, SP }\end{array}$ & 7/3/1921 & & & Fotografia & Débil mental & & \\
\hline DAP 075 & B.T. & M & 46 & Branca & Italiana & & Casado & Colono & Católica & & $\begin{array}{l}\text { Espírito } \\
\text { Santo do } \\
\text { Pinhal, SP }\end{array}$ & 7/3/1921 & & & Fotografia & & Réu & $\begin{array}{l}\text { Feriu a mulher, em } \\
\text { diversos lugares, com } \\
\text { uma faca de mesa. }\end{array}$ \\
\hline DAP 253 & J.J.R. & M & 26 & Parda & Brasileira & & Solteiro & $\begin{array}{l}\text { Traba- } \\
\text { lhador da } \\
\text { roça }\end{array}$ & Católica & Analfabeto & $\begin{array}{l}\text { Igarapava, } \\
\text { SP }\end{array}$ & $7 / 13 / 1921$ & $11 / 12 / 1931$ & Óbito & Fotografia & $\begin{array}{l}\text { Alcoolismo } \\
\text { crônico }\end{array}$ & $\begin{array}{l}\text { Réu, por } \\
\text { homicídio. }\end{array}$ & \\
\hline DAP 147 & P.G.M. & M & 33 & Branca & $\begin{array}{l}\text { Espa- } \\
\text { nhola }\end{array}$ & $\begin{array}{l}\text { Valla- } \\
\text { dolid, } \\
\text { Espanha }\end{array}$ & Solteiro & $\begin{array}{l}\text { Liberal/ } \\
\text { serven- } \\
\text { te de } \\
\text { pedreiro }\end{array}$ & & Alfabetizado & $\begin{array}{l}\text { Cadeia Pú- } \\
\text { blica, SP }\end{array}$ & $8 / 13 / 1921$ & & & $\begin{array}{l}\text { Fotografia } \\
\text { e digitais }\end{array}$ & Parafrenia & $\begin{array}{l}\text { Réu (art. } \\
294 \text { do } \\
\text { Código } \\
\text { Penal } \$ 1^{\circ} \text {, } \\
\text { combinado } \\
\text { com arts. } \\
13 \text { e 63). } \\
\text { por homi- } \\
\text { cídio. }\end{array}$ & $\begin{array}{l}\text { Cartas do interno, guia } \\
\text { de clínicas especializa- } \\
\text { das, devido a cirurgia. }\end{array}$ \\
\hline DAP 328 & P.M. & $M$ & 72 & Branca & Italiana & & Viúvo & Pedreiro & & Alfabetizado & $\begin{array}{l}\text { São Paulo, } \\
\text { SP }\end{array}$ & 9/11/1921 & & & & $\begin{array}{l}\text { Doença senil, } \\
\text { presbiofrenia }\end{array}$ & Réu & $\begin{array}{l}\text { Não consta o crime e } \\
\text { o réu não sabe o que } \\
\text { ocorreu. }\end{array}$ \\
\hline DAP 397 & V.B. & $M$ & 31 & Branca & Italiana & $\begin{array}{l}\text { Veneza, } \\
\text { Itália }\end{array}$ & $\begin{array}{l}\text { Solteiro } \\
\text { Chioia, } \\
\text { Veneza, } \\
\text { Itália }\end{array}$ & $\begin{array}{l}\text { Pedreiro/ } \\
\text { pintor }\end{array}$ & Católica & Alfabetizado & $\begin{array}{l}\text { Peniten- } \\
\text { ciária do } \\
\text { Estado, } \\
\text { SP }\end{array}$ & $\begin{array}{l}\text { 20/09/1921, } \\
30 / 05 / 1922, \\
05 / 02 / 1925 \text { e } \\
24 / 07 / 1929\end{array}$ & $\begin{array}{l}14 / 01 / 1922, \\
10 / 07 / 1923, \\
21 / 10 / 1926 \\
\mathrm{e} \\
15 / 02 / 1936\end{array}$ & & & $\begin{array}{l}\text { Perturbaçōes } \\
\text { psicógenas, } \\
\text { delírio de } \\
\text { influência. }\end{array}$ & Réu & $\begin{array}{l}\text { Bebia, no botequim } \\
\text { com os amigos, ao lado } \\
\text { de uma festa de famí- } \\
\text { lia. Seu pai o mandou } \\
\text { ir à festa encontrar a } \\
\text { irmā. Foi agredido por } \\
\text { um homem e, para se } \\
\text { defender, "atirou-lhe } \\
\text { tiros pela arma". Cartas } \\
\text { do próprio réu. }\end{array}$ \\
\hline DAP 035 & A.A. & M & 19 & Branca & Brasileira & & Solteiro & & Católica & & $\begin{array}{l}\text { Capivari, } \\
\text { SP }\end{array}$ & 9/24/1921 & & & Fotografia & Loucura moral & Réu & $\begin{array}{l}\text { Peso por haver furtado } \\
\text { seu pais e levado } \\
\text { uma vida de boêmio e } \\
\text { vagabundo. }\end{array}$ \\
\hline
\end{tabular}




\begin{tabular}{|c|c|c|c|c|c|c|c|c|c|c|c|c|c|c|c|c|c|c|}
\hline 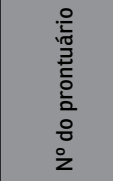 & 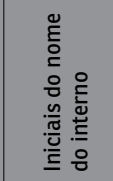 & ஓ̊̀ & 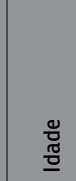 & ò & 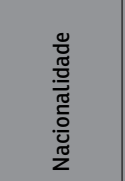 & 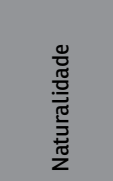 & 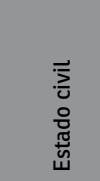 & 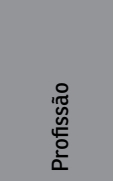 & $\begin{array}{l}\frac{0}{\pi} \\
\frac{\pi}{\pi} \\
\frac{\pi}{\pi}\end{array}$ & 总 & 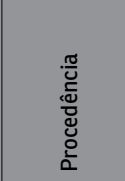 & 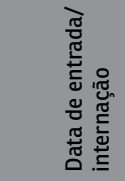 & $\begin{array}{l}\frac{\pi}{0} \\
\frac{0}{5} \\
\frac{\pi}{\pi} \\
\frac{\pi}{\pi} \\
0\end{array}$ & 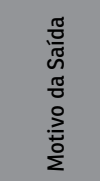 & 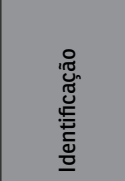 & 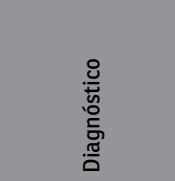 & 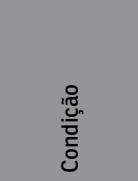 & 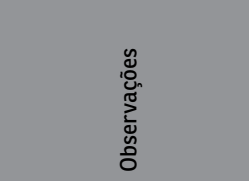 \\
\hline DAP 376 & s.z. & $M$ & 56 & Branca & Italiana & $\begin{array}{l}\text { Bolonha, } \\
\text { Itália }\end{array}$ & Viúvo & & & Analfabeto & & 9/25/1921 & s.d. & & & $\begin{array}{l}\text { Debilidade } \\
\text { mental }\end{array}$ & & $\begin{array}{l}\text { A mulher resolveu vir } \\
\text { para o Brasil. Trabalha } \\
\text { como carroceiro, } \\
\text { na lavoura e como } \\
\text { cozinheiro. Sua mulher } \\
\text { morre cedo e seu único } \\
\text { filho vai para guerra. } \\
\text { Mora com uma mendi- } \\
\text { ga e começa a roubar. } \\
\text { Tenta o suicídio. }\end{array}$ \\
\hline DAP 251 & $\begin{array}{l}\text { J.I.M. } \\
\text { (vulgo } \\
\text { José } \\
\text { Botão) }\end{array}$ & M & 58 & Branca & Brasileira & $\begin{array}{l}\text { Rio Cla- } \\
\text { ro, SP }\end{array}$ & Casado & & & Analfabeto & $\begin{array}{l}\text { Peniten- } \\
\text { ciária do } \\
\text { Estado, } \\
\text { SP }\end{array}$ & $10 / 6 / 1921$ & & & Fotografia & $\begin{array}{l}\text { Débil mental } \\
\text { com episódios } \\
\text { delirantes. }\end{array}$ & $\begin{array}{l}\text { Réu (art. } \\
294 \text { do Có- } \\
\text { digo Penal } \\
\mathbb{S} 2^{\circ} \text { ). }\end{array}$ & $\begin{array}{l}\text { Após discutir com um } \\
\text { vizinho, desferiu-lhe } \\
\text { golpe com um cacete. } \\
\text { No dia seguinte, entre- } \\
\text { gou-se à polícia. }\end{array}$ \\
\hline DAP 249 & J.G. & M & 23 & Branca & Brasileira & & Solteiro & $\begin{array}{l}\text { Jorna- } \\
\text { leiro }\end{array}$ & & Alfabetizado & $\begin{array}{l}\text { São João } \\
\text { da Boa } \\
\text { Vista, SP }\end{array}$ & $11 / 26 / 1921$ & 6/2/1934 & $\begin{array}{l}\text { Trans- } \\
\text { ferência } \\
\text { para o } \\
\text { Mani- } \\
\text { cômio } \\
\text { Pirapi- } \\
\text { tingui }\end{array}$ & $\begin{array}{l}\text { Foto- } \\
\text { grafias } \\
\text { e arcada } \\
\text { dentária }\end{array}$ & $\begin{array}{l}\text { Débil mental } \\
\text { alcoolista }\end{array}$ & $\begin{array}{l}\text { Réu (art. } \\
294 \text { do Có- } \\
\text { digo Penal } \\
\mathbb{S} 2^{\circ} \text { ). }\end{array}$ & $\begin{array}{l}\text { Alegou defesa própria, } \\
\text { ao ser perseguido pela } \\
\text { vitima. Recorte de jor- } \\
\text { nal sobre o interno. }\end{array}$ \\
\hline DAP 286 & L.F.S. & $M$ & 21 & Branca & Brasileira & $\begin{array}{l}\text { São Pau- } \\
\text { lo, SP }\end{array}$ & Viúvo & & & & $\begin{array}{l}\text { Peniten- } \\
\text { ciária do } \\
\text { Estado, } \\
\text { SP }\end{array}$ & $12 / 8 / 1921$ & & & & $\begin{array}{l}\text { Ataques histé- } \\
\text { ricos de caráter } \\
\text { epileptoide }\end{array}$ & $\begin{array}{l}\text { Absolvido, } \\
\text { por homi- } \\
\text { cídio da } \\
\text { esposa. }\end{array}$ & \\
\hline 0041 & R.S. & $M$ & 22 & Branca & Brasileira & $\begin{array}{l}\text { Valença, } \\
\text { BA }\end{array}$ & Solteiro & $\begin{array}{l}\text { Encader- } \\
\text { nador }\end{array}$ & & Analfabeto & $\begin{array}{l}\text { Peniten- } \\
\text { ciária do } \\
\text { Estado, SP }\end{array}$ & $2 / 9 / 1922$ & & & Fotografia & & $\begin{array}{l}\text { Réu, por } \\
\text { furto. }\end{array}$ & \\
\hline DAP 277 & $\begin{array}{l}\text { LA.L.M. } \\
\text { (vulgo } \\
\text { Laurindo } \\
\text { Gomes) }\end{array}$ & M & 58 & Branca & Brasileira & $\begin{array}{l}\text { Nazaré, } \\
\text { SP }\end{array}$ & Casado & & & $\begin{array}{l}\text { Alfabeti- } \\
\text { zado (não } \\
\text { frequentou } \\
\text { escola) }\end{array}$ & $\begin{array}{l}\text { Socorro, } \\
\text { SP }\end{array}$ & $3 / 25 / 1922$ & 8/8/1941 & Óbito & $\begin{array}{l}\text { Fotografia, } \\
\text { medidas } \\
\text { corpo- } \\
\text { rais,di- } \\
\text { gitais e } \\
\text { arcada } \\
\text { dentária }\end{array}$ & $\begin{array}{l}\text { Delírios de } \\
\text { grandeza, } \\
\text { psicose manía- } \\
\text { co- depressiva } \\
\text { e demência } \\
\text { servil, surtos } \\
\text { violentos. }\end{array}$ & $\begin{array}{l}\text { Condenado } \\
\text { a } 10 \text { anos e } \\
6 \text { meses de } \\
\text { prisão ce- } \\
\text { lular (art. } \\
294, \$ 2^{\circ} \\
\text { do Código } \\
\text { Penal), por } \\
\text { homicídio } \\
\text { do cunha- } \\
\text { do. }\end{array}$ & $\begin{array}{l}\text { Embriagado, matou a } \\
\text { vitima a facadas. Ten- } \\
\text { tou fugir e se suicidar } \\
\text { na cadeia. Acreditava } \\
\text { que seria executado } \\
\text { e alegava ser "dono } \\
\text { de Jerusalém, por ele } \\
\text { mesmo construída, } \\
\text { em horra a Nossa } \\
\text { Senhora". }\end{array}$ \\
\hline DAP 095 & B.R.S. & M & & Parda & Brasileira & & & $\begin{array}{l}\text { Trabalha- } \\
\text { dor rural }\end{array}$ & & & $\begin{array}{l}\text { Pitanguei- } \\
\text { ras, SP }\end{array}$ & $4 / 1 / 1922$ & 9/7/1922 & & & & $\begin{array}{l}\text { Réu, por } \\
\text { homicídio } \\
\text { contra o } \\
\text { cunhado }\end{array}$ & \\
\hline DAP 232 & J.B. & M & 25 & Preta & Brasileira & $\begin{array}{l}\text { Valinhos, } \\
\text { SP }\end{array}$ & Casado & Lavrador & & Analfabeto & $\begin{array}{l}\text { Peniten- } \\
\text { ciária de } \\
\text { Itatiba, SP }\end{array}$ & $4 / 20 / 1922$ & & & Fotografia & Parafrenia & $\begin{array}{l}\text { Senten- } \\
\text { ciado }\end{array}$ & $\begin{array}{l}\text { Internado após } \\
\text { perseguir e agredir } \\
\text { uma mulher, por esta } \\
\text { não ter cedido às suas } \\
\text { investidas. Apresentou } \\
\text { quadro violento, porém, } \\
\text { não foi diagnosticado. }\end{array}$ \\
\hline
\end{tabular}




\begin{tabular}{|c|c|c|c|c|c|c|c|c|c|c|c|c|c|c|c|c|c|c|}
\hline 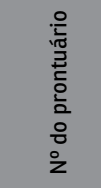 & 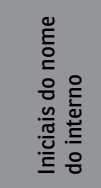 & ஓ्̀ & $\begin{array}{l}\frac{\pi}{\pi} \\
\frac{\pi}{2}\end{array}$ & ¿̀ & 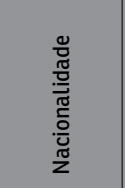 & 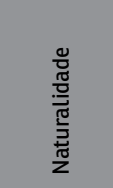 & 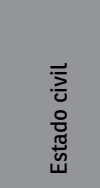 & 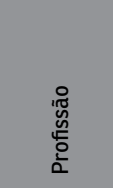 & : & 空 & 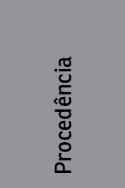 & 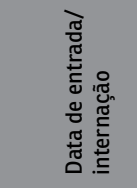 & $\begin{array}{l}\frac{\pi}{\pi} \\
\frac{0}{\pi} \\
0 \\
0 \\
\frac{\pi}{\pi} \\
0\end{array}$ & 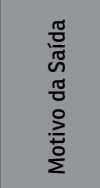 & 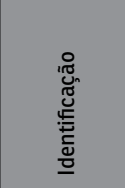 & 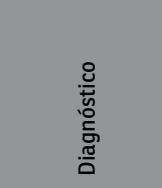 & 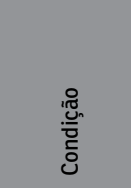 & 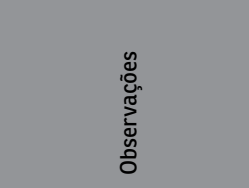 \\
\hline DAP 397 & S.L.S. & & 28 & Parda & Brasileira & & Casado & & Católica & Alfabetizado & Bauru, SP & $4 / 21 / 1922$ & & & Fotografia & $\begin{array}{l}\text { Débil mental, } \\
\text { alcoolista }\end{array}$ & Réu & $\begin{array}{l}\text { Homicídio praticado } \\
\text { com um revólver. }\end{array}$ \\
\hline DAP 366 & S.B. & M & 40 & Branca & Brasileira & & Casado & $\begin{array}{l}\text { Traba- } \\
\text { thador de } \\
\text { roça }\end{array}$ & Católica & & $\begin{array}{l}\text { Piracica- } \\
\text { ba, SP }\end{array}$ & $5 / 2 / 1922$ & ??/04/1934 & & Fotografia & Eplepsia & $\begin{array}{l}\text { Réu, por } \\
\text { homicídio } \\
\text { contra um } \\
\text { amigo. }\end{array}$ & $\begin{array}{l}\text { Crime sem motivo apa- } \\
\text { rente, com uma faca de } \\
\text { cortar fumo. }\end{array}$ \\
\hline DAP 388 & P.V.M. & M & 42 & Branca & Brasileira & $\begin{array}{l}\text { Taquari- } \\
\text { tinga, SP }\end{array}$ & Casado & Lavrador & Católica & Alfabetizado & & $6 / 19 / 1922$ & & & $\begin{array}{l}\text { Fotografia } \\
\text { e assina- } \\
\text { tura }\end{array}$ & $\begin{array}{l}\text { Não sofre das } \\
\text { faculdades } \\
\text { mentais }\end{array}$ & Réu & $\begin{array}{l}\text { Agrediu a família da } \\
\text { esposa, durante uma } \\
\text { discussão. }\end{array}$ \\
\hline DAP 195 & $\begin{array}{l}\text { J.B.S. } \\
\text { (vulgo } \\
\text { João da } \\
\text { Helena) }\end{array}$ & M & 32 & Preta & Brasileira & $\begin{array}{l}\text { Serra Ne- } \\
\text { gra, SP }\end{array}$ & Solteiro & $\begin{array}{l}\text { Operário } \\
\text { agrícola }\end{array}$ & Católica & Alfabetizado & $\begin{array}{l}\text { Amparo, } \\
\text { SP }\end{array}$ & $8 / 31 / 1922$ & $3 / 6 / 1946$ & $\begin{array}{l}\text { Liber- } \\
\text { dade } \\
\text { vigiada }\end{array}$ & $\begin{array}{l}\text { Fotografia } \\
\text { e digitais }\end{array}$ & $\begin{array}{l}\text { Eplepsia tóxica } \\
\text { endógena }\end{array}$ & $\begin{array}{l}\text { Réu, por } \\
\text { agressão à } \\
\text { compa- } \\
\text { nheira. }\end{array}$ & $\begin{array}{l}\text { Considerado perigoso, } \\
\text { foi mantido em liber- } \\
\text { dade vigiada. No ma- } \\
\text { nicômio, trabalhou no } \\
\text { jardim e pomar. Carta } \\
\text { escrita pelo interno, na } \\
\text { qual consta um pedido } \\
\text { de liberdade para o } \\
\text { diretor da instituição. }\end{array}$ \\
\hline DAP 269 & J.S. & M & 26 & Parda & Brasileira & & & & Católica & Analfabeto & $\begin{array}{l}\text { Cadeia de } \\
\text { São Joāo } \\
\text { da Boa } \\
\text { Vista, SP }\end{array}$ & 9/4/1922 & $2 / 2 / 1932$ & $\begin{array}{l}\text { Trans- } \\
\text { ferência } \\
\text { para o } \\
\text { Hospital } \\
\text { do Ju- } \\
\text { query } \\
\end{array}$ & Fotografia & Imbecil & Réu & \\
\hline 0026 & A.G. & M & 29 & Branca & Italiana & & Solteiro & Operário & Católica & Alfabetizado & & $9 / 22 / 1922$ & $4 / 26 / 1923$ & & Fotografia & $\begin{array}{l}\text { Degenerado } \\
\text { psíquico }\end{array}$ & $\begin{array}{l}\text { Tenta- } \\
\text { tiva de } \\
\text { homicídio } \\
\text { contra a } \\
\text { namorada. }\end{array}$ & $\begin{array}{l}\text { Relato do crime feito } \\
\text { durante um exame psí- } \\
\text { quico. Aparentemente } \\
\text { não foi submetido a } \\
\text { nenhum exame durante } \\
\text { sua internação. Crime } \\
\text { movido por ciúmes. }\end{array}$ \\
\hline DAP 098 & B.S. & M & 32 & Parda & Brasileira & & Solteiro & & Católica & Analfabeto & $\begin{array}{l}\text { São José } \\
\text { do Barrei- } \\
\text { ro, SP }\end{array}$ & $9 / 27 / 1922$ & & & Fotografia & $\begin{array}{l}\text { Débil mental, } \\
\text { alcoolista. }\end{array}$ & Réu & $\begin{array}{l}\text { Internado após matar } \\
\text { uma pessoa notável } \\
\text { de sua cidade. Não é } \\
\text { citada a circunstância } \\
\text { ou motivação, mas há } \\
\text { descrição do crime. }\end{array}$ \\
\hline DAP 324 & O.G.S. & M & 25 & Preta & Brasileira & & Solteiro & Seleiro & Católica & & $\begin{array}{l}\text { Bragança, } \\
\text { SP }\end{array}$ & $9 / 27 / 1922$ & $8 / 11 / 1922$ & Fuga & Fotografia & Parafrenia & & $\begin{array}{l}\text { Internado por disparar } \\
\text { contra um senhor de } \\
80 \text { anos, após ter sido } \\
\text { agredido pelo mesmo } \\
\text { com uma faca, sem } \\
\text { motivo aparente. }\end{array}$ \\
\hline DAP 112 & C.S.B. & M & 38 & Preta & Brasileira & & & & & & $\begin{array}{l}\text { Igarapava, } \\
\text { SP }\end{array}$ & $10 / 16 / 1922$ & $10 / 26 / 1922$ & Óbito & & & Réu & \\
\hline
\end{tabular}




\begin{tabular}{|c|c|c|c|c|c|c|c|c|c|c|c|c|c|c|c|c|c|c|}
\hline 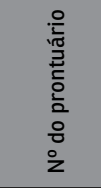 & 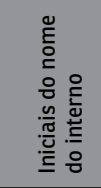 & ঙั̊ & 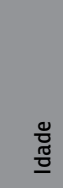 & ¿̀ & 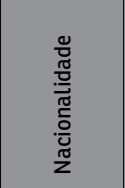 & 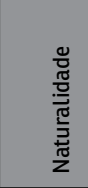 & 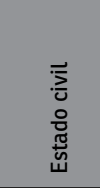 & 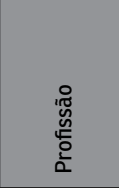 & $\frac{: 0}{\frac{10}{9}}$ & 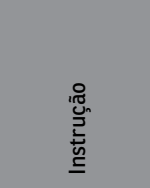 & 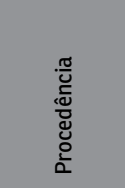 & 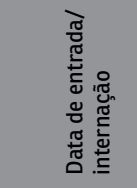 & $\begin{array}{l}\frac{\pi}{0} \\
\frac{\pi}{\pi} \\
0 \\
0 \\
\frac{\pi}{\pi} \\
\frac{\pi}{0}\end{array}$ & $\begin{array}{l}\frac{\pi}{0} \\
0 \\
0 \\
\frac{\pi}{0} \\
0 \\
0 \\
\frac{D}{0} \\
\frac{0}{2}\end{array}$ & 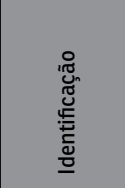 & 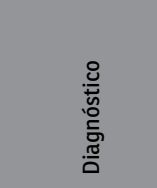 & 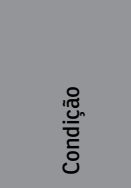 & 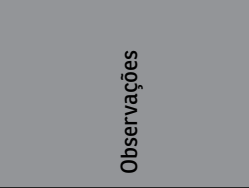 \\
\hline DAP 029 & A.F. & M & 56 & Branca & Italiana & & Viúvo & Sapateiro & & Alfabetizado & $\begin{array}{l}\text { São Paulo, } \\
\text { SP }\end{array}$ & $10 / 21 / 1922$ & & & Fotografia & $\begin{array}{l}\text { Alcoolismo } \\
\text { crônico }\end{array}$ & $\begin{array}{l}\text { Réu, por } \\
\text { homicídio } \\
\text { contra a } \\
\text { compa- } \\
\text { nheira. }\end{array}$ & Descrição do crime. \\
\hline DAP 345 & P.P.S. & M & 22 & Branca & Brasileira & & Solteiro & Lavrador & & Analfabeto & $\begin{array}{l}\text { Peniten- } \\
\text { ciária do } \\
\text { Estado, } \\
\text { SP }\end{array}$ & $11 / 4 / 1922$ & & & Fotografia & Imbecilidade & $\begin{array}{l}\text { Réu, por } \\
\text { homicídio } \\
\text { contra o } \\
\text { irmão. }\end{array}$ & Pais alcoólatras. \\
\hline DAP 106 & C.I. & M & 64 & Branca & Italiana & & Solteiro & Lavrador & Católica & Analfabeto & $\begin{array}{l}\text { Comarca } \\
\text { de Ribei- } \\
\text { rão Preto, } \\
\text { SP } \\
\end{array}$ & $12 / 31 / 1922$ & 2/5/1941 & Óbito & Fotografia & Parafrenia & Réu & $\begin{array}{l}\text { Recorte de jornal tra- } \\
\text { tando da sentença. }\end{array}$ \\
\hline 0097 & B.S.G. & M & 24 & Branca & Brasileira & & Solteiro & Lavrador & Católica & & $\begin{array}{l}\text { São Paulo, } \\
\text { SP }\end{array}$ & $3 / 3 / 1923$ & 2/2/1932 & $\begin{array}{l}\text { Trans- } \\
\text { ferência } \\
\text { para o } \\
\text { Hospital } \\
\text { do Ju- } \\
\text { query }\end{array}$ & Fotografia & Imbecilidade & $\begin{array}{l}\text { Réu, por } \\
\text { homicídio } \\
\text { contra o } \\
\text { pai. }\end{array}$ & $\begin{array}{l}\text { Poucas informaçōes, } \\
\text { em virtude do incêndio } \\
\text { ocorrido no arquivo do } \\
\text { Segundo Ofício do Júri } \\
\text { na Revoluçāo de } 1924 . \\
\text { Memorando infor- } \\
\text { mando que o interno é } \\
\text { foragido e depoimentos } \\
\text { de testemunhas. }\end{array}$ \\
\hline DAP 223 & J.L.F. & M & & Branca & Brasileira & & Solteiro & Lavrador & & & $\begin{array}{l}\text { São Paulo, } \\
\text { SP }\end{array}$ & $3 / 11 / 1923$ & $10 / 2 / 1940$ & Óbito & Fotografia & $\begin{array}{l}\text { Debilidade } \\
\text { mental }\end{array}$ & & $\begin{array}{l}\text { Sempre manifestou } \\
\text { um comportamento } \\
\text { bastante acanhado. }\end{array}$ \\
\hline 0126 & D.J.M. & M & 28 & Preta & Brasileira & & Casado & $\begin{array}{l}\text { Trabalha- } \\
\text { dor rural }\end{array}$ & & & $\begin{array}{l}\text { São João } \\
\text { da Boa } \\
\text { Vista, SP }\end{array}$ & $3 / 22 / 1923$ & $7 / 12 / 1923$ & & Fotografia & & $\begin{array}{l}\text { Réu, por } \\
\text { agressōes } \\
\text { fisicas } \\
\text { contra o } \\
\text { enteado. }\end{array}$ & \\
\hline DAP 039 & J.P.D. & M & 26 & Branca & Brasileira & Bahia & Solteiro & Lavrador & Católica & Alfabetizado & $\begin{array}{l}\text { Caeia } \\
\text { Pública de } \\
\text { Igaravapa, } \\
\text { SP }\end{array}$ & $3 / 27 / 1923$ & & $\begin{array}{l}\text { Trans- } \\
\text { ferência } \\
\text { para a } \\
\text { prisão }\end{array}$ & Fotografia & & $\begin{array}{l}\text { Senten- } \\
\text { ciado, por } \\
\text { homicídio } \\
\text { contra } \\
\text { compa- } \\
\text { nheiro de } \\
\text { trabalho. }\end{array}$ & $\begin{array}{l}\text { Após anos de reclusão, } \\
\text { começou a manifestar } \\
\text { comportamento inquie- } \\
\text { to, agindo de forma } \\
\text { desesperada e, por } \\
\text { isso, foi encaminhado a } \\
\text { exames psíquicos. }\end{array}$ \\
\hline 0263 & J.M.S. & M & 24 & Parda & Brasileira & $\begin{array}{l}\text { Piraju, } \\
\text { SP }\end{array}$ & Casado & Lavrador & Católica & Analfabeto & Piraju, SP & $4 / 21 / 1923$ & $2 / 27 / 1930$ & & Fotografia & $\begin{array}{l}\text { Degeneração, } \\
\text { demência } \\
\text { precoce. }\end{array}$ & $\begin{array}{l}\text { Senten- } \\
\text { ciado a } \\
\text { reclusão } \\
\text { de } 6 \text { anos, } \\
\text { por furto e } \\
\text { homicídio. }\end{array}$ & $\begin{array}{l}\text { Comportamento indis- } \\
\text { ciplinado na Penitenci- } \\
\text { ária de Piraju, onde foi } \\
\text { condenado a cumprir } \\
\text { pena. Anteriormente, } \\
\text { havia registros de fugas } \\
\text { do indivíduo. }\end{array}$ \\
\hline
\end{tabular}




\begin{tabular}{|c|c|c|c|c|c|c|c|c|c|c|c|c|c|c|c|c|c|c|}
\hline 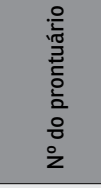 & 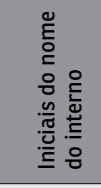 & ঙั̀ & $\begin{array}{l}\text { 莺 } \\
\text { 五 }\end{array}$ & ¿̀ & $\begin{array}{l}\frac{\pi}{\pi} \\
\frac{\pi}{\pi} \\
\frac{\pi}{\pi} \\
\frac{0}{0} \\
\frac{\pi}{2} \\
\end{array}$ & $\begin{array}{l}\frac{2}{0} \\
\frac{\pi}{0} \\
\frac{\pi}{50} \\
\frac{\pi}{2} \\
\frac{\pi}{2}\end{array}$ & 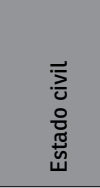 & 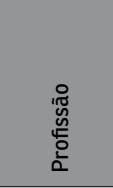 & $\begin{array}{l}\frac{0}{\pi} \\
\frac{10}{\pi} \\
\frac{\pi}{\pi}\end{array}$ & 突 & 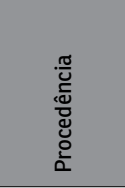 & 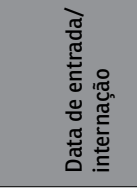 & 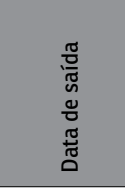 & 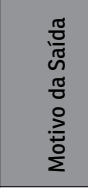 & 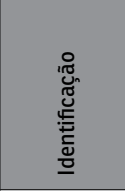 & 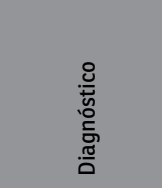 & 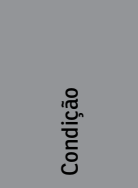 & 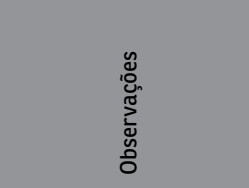 \\
\hline DAP 219 & J.S. & M & 28 & Branca & Brasileira & & Solteiro & $\begin{array}{l}\text { Enfer- } \\
\text { meiro }\end{array}$ & Católica & Alfabetizado & $\begin{array}{l}\text { Cadeia de } \\
\text { Taquari- } \\
\text { tinga, SP }\end{array}$ & $5 / 27 / 1923$ & & & Fotografia & $\begin{array}{l}\text { Psicose manía- } \\
\text { ca-depressiva }\end{array}$ & $\begin{array}{l}\text { Réu, por } \\
\text { roubo. }\end{array}$ & $\begin{array}{l}\text { Relato do crime, } \\
\text { feito durante um exame } \\
\text { psíquico. }\end{array}$ \\
\hline 0154 & F.B. & M & 72 & Branca & Italiana & & Viúvo & Mecânico & & Alfabetizado & $\begin{array}{l}\text { Santa Rita } \\
\text { do Passa } \\
\text { Quatro, } \\
\text { SP }\end{array}$ & $6 / 16 / 1923$ & 8/10/1926 & Óbito & & $\begin{array}{l}\text { Esclerose } \\
\text { cerebral }\end{array}$ & Absolvido & $\begin{array}{l}\text { Termo de declaração } \\
\text { do interno. Carta e poe- } \\
\text { mas do interno. Recorte } \\
\text { de jornal que relata o } \\
\text { furto, a audieincia e a } \\
\text { sentença. }\end{array}$ \\
\hline DAP 250 & J.H.L. & M & 55 & Branca & Brasileira & & & & Católica & Analfabeto & $\begin{array}{l}\text { Pindamo- } \\
\text { nhangaba, } \\
\text { SP }\end{array}$ & $6 / 20 / 1923$ & & & Fotografia & Parafrenia & & \\
\hline DAP 314 & N.M. & M & 27 & Branca & Brasileira & $\begin{array}{l}\text { Soroca- } \\
\text { ba, SP }\end{array}$ & Solteiro & $\begin{array}{l}\text { Pedreiro/ } \\
\text { operário }\end{array}$ & Católica & Alfabetizado & $\begin{array}{l}\text { Cadeia } \\
\text { Pública de } \\
\text { Sorocaba, } \\
\text { SP }\end{array}$ & $7 / 6 / 1923$ & 7/19/1937 & Óbito & Fotografia & $\begin{array}{l}\text { Demência } \\
\text { precoce }\end{array}$ & $\begin{array}{l}\text { Senten- } \\
\text { ciado a } 16 \\
\text { anos, por } \\
\text { homicídio } \\
\text { contra } \\
\text { menor. }\end{array}$ & \\
\hline 0331 & P.A.A. & M & 46 & Branca & Brasileira & $\begin{array}{l}\text { Juquery, } \\
\text { SP }\end{array}$ & Casado & Lavrador & Católica & Analfabeto & $\begin{array}{l}\text { Comarca } \\
\text { de Atibaia, } \\
\text { SP }\end{array}$ & $7 / 27 / 1923$ & $1 / 11 / 1932$ & Óbito & Fotografia & & Absolvido & $\begin{array}{l}\text { Guia de internação, } \\
\text { declaração de pobreza. } \\
\text { Cópia de partes do pro- } \\
\text { cesso criminal. Interna- } \\
\text { do após matar a esposa } \\
\text { e o enteado, com uma } \\
\text { foice. Segundo relato } \\
\text { policial, ele não estava } \\
\text { em seu juízo perfeito ao } \\
\text { ser interrogado. }\end{array}$ \\
\hline 0290 & L.N.G. & M & 65 & Branca & Italiana & & Solteiro & $\begin{array}{l}\text { Nego- } \\
\text { ciante } \\
\text { ambu- } \\
\text { lante }\end{array}$ & Católica & Analfabeto & $\begin{array}{l}\text { São Paulo, } \\
\text { SP }\end{array}$ & $10 / 18 / 1923$ & & & Fotografia & $\begin{array}{l}\text { Demência } \\
\text { paralítica }\end{array}$ & $\begin{array}{l}\text { Acusado de } \\
\text { passar nota } \\
\text { falsa. }\end{array}$ & \\
\hline 0209 & J.L. & M & 22 & Branca & Brasileira & & Solteiro & Sapateiro & Católica & & $\begin{array}{l}\text { São Paulo, } \\
\text { SP }\end{array}$ & $10 / 26 / 1923$ & 3/19/1927 & Óbito & Fotografia & $\begin{array}{l}\text { Demência } \\
\text { precoce }\end{array}$ & Réu & $\begin{array}{l}\text { Internado por desferir } \\
\text { duas facadas contra a } \\
\text { vitima }\end{array}$ \\
\hline 0189 & J.B.S. & $\mathrm{F}$ & 37 & Branca & Italiana & & Casada & $\begin{array}{l}\text { Serviços } \\
\text { domésti- } \\
\text { cos }\end{array}$ & Católica & & $\begin{array}{l}\text { Rio Claro, } \\
\text { SP }\end{array}$ & $10 / 29 / 1923$ & $3 / 11 / 1927$ & Óbito & Fotografia & $\begin{array}{l}\text { Demência } \\
\text { precoce }\end{array}$ & Ré & $\begin{array}{l}\text { Matou o marido com } \\
\text { água fervente. Seu } \\
\text { estado varia entre a } \\
\text { chegada e um exame } \\
\text { posterior, e tendeu a } \\
\text { piorar. }\end{array}$ \\
\hline
\end{tabular}




\begin{tabular}{|c|c|c|c|c|c|c|c|c|c|c|c|c|c|c|c|c|c|c|}
\hline 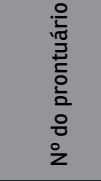 & 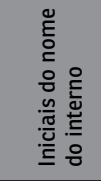 & ֻั̊ & $\begin{array}{l}\frac{\pi}{\pi} \\
\text { 五 }\end{array}$ & ¿̀ & 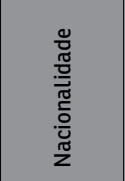 & $\begin{array}{l}\frac{\pi}{\pi} \\
\frac{\pi}{5} \\
\frac{\pi}{\pi} \\
\frac{\pi}{2}\end{array}$ & 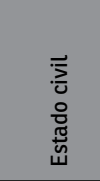 & 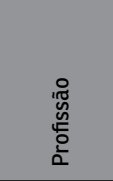 & $\frac{.0}{\frac{10}{\pi}}$ & 㝕 & 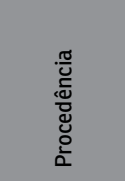 & 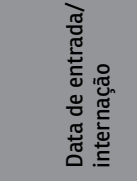 & $\begin{array}{l}\frac{\pi}{\pi} \\
\frac{\pi}{\pi} \\
0 \\
\frac{\pi}{\pi} \\
\frac{\pi}{0}\end{array}$ & 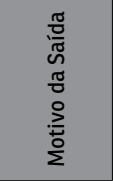 & 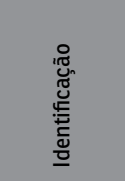 & 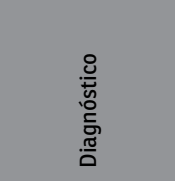 & 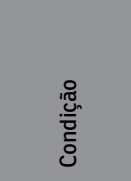 & 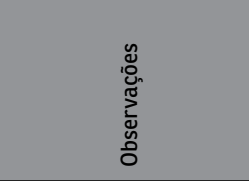 \\
\hline DAP 297 & M.R.S. & $\mathrm{F}$ & 30 & Parda & Brasileira & & Casada & $\begin{array}{l}\text { Domés- } \\
\text { tica }\end{array}$ & & $\begin{array}{l}\text { Alfabetizada } \\
\text { (semianalfa- } \\
\text { beta) }\end{array}$ & Assis, SP & $12 / 2 / 1923$ & $1 / 1 / 1945$ & Óbito & Fotografia & $\begin{array}{l}\text { Demência pre- } \\
\text { coce paranóide }\end{array}$ & $\begin{array}{l}\text { Ré, por } \\
\text { homicídio } \\
\text { contra a } \\
\text { filha. }\end{array}$ & $\begin{array}{l}\text { Crime cometido a faca- } \\
\text { das no pescocoo, sendo } \\
\text { que anteriormente já } \\
\text { apresentava sintomas } \\
\text { de instabilidade } \\
\text { mental. }\end{array}$ \\
\hline DAP 320 & O.F.S. & $\mathrm{F}$ & 24 & Parda & Brasileira & & Solteira & & & & $\begin{array}{l}\text { Capivari, } \\
\text { SP }\end{array}$ & $12 / 23 / 1923$ & & & Fotografia & $\begin{array}{l}\text { Psicose ma- } \\
\text { níaca }\end{array}$ & $\begin{array}{l}\text { Ré, por } \\
\text { homicídio } \\
\text { contra a } \\
\text { filha. }\end{array}$ & $\begin{array}{l}\text { A vítima era recém- } \\
\text {-nascida. }\end{array}$ \\
\hline DAP 020 & A.C. & M & 34 & Branca & $\begin{array}{l}\text { Portu- } \\
\text { guesa }\end{array}$ & $\begin{array}{l}\text { Rates, } \\
\text { Portugal }\end{array}$ & Solteiro & $\begin{array}{l}\text { Vendedor } \\
\text { ambu- } \\
\text { lante }\end{array}$ & & & $\begin{array}{l}\text { Cadeia } \\
\text { Pública da } \\
\text { Capital, } \\
\text { SP }\end{array}$ & $5 / 15 / 1924$ & 12/8/1937 & Óbito & $\begin{array}{l}\text { Fotografia } \\
\text { e digitais }\end{array}$ & Epilepsia & $\begin{array}{l}\text { Sentencia- } \\
\text { do por ferir } \\
\text { a faca o } \\
\text { inspetor de } \\
\text { segurança. }\end{array}$ & $\begin{array}{l}\text { Alvo de tiros por um } \\
\text { terceiro homem. A } \\
\text { confusão levou-o a } \\
\text { ser condenado, apesar } \\
\text { do homem que fora } \\
\text { esfaqueado permane- } \\
\text { cer vivo e bem. Não é } \\
\text { possível saber o motivo } \\
\text { de sua remoção para o } \\
\text { manicômio. }\end{array}$ \\
\hline DAP 064 & A.M. & M & 30 & Parda & Brasileira & $\begin{array}{l}\text { Minas } \\
\text { Gerais }\end{array}$ & Casado & $\begin{array}{l}\text { Jorna- } \\
\text { leiro }\end{array}$ & Católica & & $\begin{array}{l}\text { Peniten- } \\
\text { ciária do } \\
\text { Estado, } \\
\text { SP }\end{array}$ & 6/6/1924 & $8 / 25 / 1950$ & $\begin{array}{l}\text { Trans- } \\
\text { ferência } \\
\text { para o } \\
\text { Hospital } \\
\text { do Ju- } \\
\text { query }\end{array}$ & Fotografia & Imbecilidade & Réu & $\begin{array}{l}\text { Considerado inapto ao } \\
\text { regime penitenciário } \\
\text { comum. }\end{array}$ \\
\hline DAP 131 & E.S. & M & 28 & Branca & Brasileira & & Solteiro & Mecânico & Católica & & $\begin{array}{l}\text { Peniten- } \\
\text { ciária do } \\
\text { Estado, } \\
\text { SP }\end{array}$ & 6/10/1924 & 4/22/1944 & Óbito & Fotografia & Imbecilidade & Latrocínio & $\begin{array}{l}\text { Apesar de constar } \\
\text { como brasileiro, consi- } \\
\text { dera-se italiano, nas- } \\
\text { cido em Roma, e teria } \\
\text { vindo para o Brasil com } \\
\text { um ano de idade. }\end{array}$ \\
\hline DAP 176 & H.C. & M & 25 & Branca & $\begin{array}{l}\text { Argen- } \\
\text { tina }\end{array}$ & & Solteiro & Operário & Católica & & $\begin{array}{l}\text { Cadeia } \\
\text { Pública da } \\
\text { Capital, } \\
\text { SP }\end{array}$ & $6 / 12 / 1924$ & 9/18/1925 & Alta & Fotografia & $\begin{array}{l}\text { Psicose hetero- } \\
\text {-tóxica }\end{array}$ & & $\begin{array}{l}\text { Alucinaçōes o levaram } \\
\text { a acreditar que um } \\
\text { homem iria ferir seu } \\
\text { amigo, atacando-o. } \\
\text { Quis fugir do serviço } \\
\text { militar na Argentina e } \\
\text { veio ao Brasil, com des- } \\
\text { tino a São Bernardo. }\end{array}$ \\
\hline
\end{tabular}




\begin{tabular}{|c|c|c|c|c|c|c|c|c|c|c|c|c|c|c|c|c|c|c|}
\hline 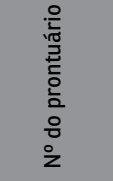 & 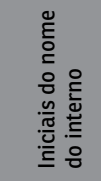 & ঙ̊̀ & $\begin{array}{l}\frac{\pi}{\pi} \\
\frac{\pi}{0}\end{array}$ & ¿̀ & 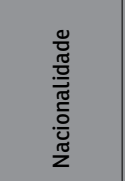 & 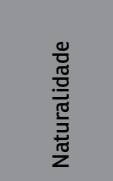 & 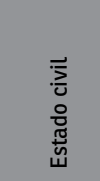 & 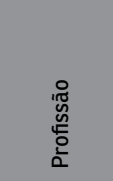 & 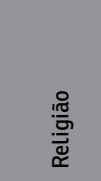 & 悹 & 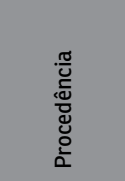 & 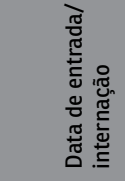 & 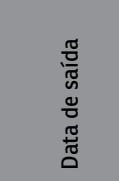 & 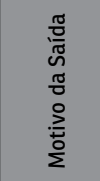 & 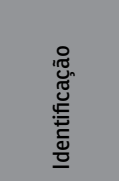 & 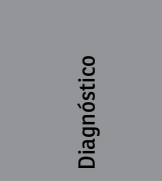 & 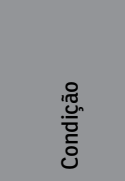 & 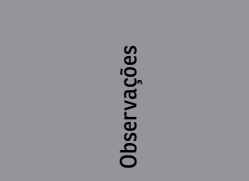 \\
\hline DAP 301 & M.S. & M & 40 & Branca & $\begin{array}{l}\text { Holan- } \\
\text { desa }\end{array}$ & & Casado & $\begin{array}{l}\text { Guarda- } \\
\text {-livros }\end{array}$ & $\begin{array}{l}\text { Protes- } \\
\text { tante }\end{array}$ & & $\begin{array}{l}\text { Santa Rita } \\
\text { do Passa } \\
\text { Quatro, } \\
\text { SP }\end{array}$ & 6/27/1924 & $6 / 27 / 1925$ & Alta & Fotografia & $\begin{array}{l}\text { Psicose de Kor- } \\
\text { sakoff, forma } \\
\text { amnésica pura. }\end{array}$ & & $\begin{array}{l}\text { Aos } 20 \text { anos de idade, } \\
\text { começou a ter pro-- } \\
\text { blemas de alcoolismo } \\
\text { crônico. }\end{array}$ \\
\hline DAP 216 & J.P. & M & 34 & Branca & Italiana & $\begin{array}{l}\text { Luca, } \\
\text { Itália }\end{array}$ & Viúvo & $\begin{array}{l}\text { Lavrador } \\
\text { e jorna- } \\
\text { leiro }\end{array}$ & Católica & & $\begin{array}{l}\text { Peniten- } \\
\text { ciária do } \\
\text { Estado, } \\
\text { SP }\end{array}$ & 9/23/1924 & $1 / 20 / 1931$ & Óbito & Fotografia & $\begin{array}{l}\text { Demência } \\
\text { precoce }\end{array}$ & $\begin{array}{l}\text { Réu, por } \\
\text { homicídio } \\
\text { contra a } \\
\text { esposa. }\end{array}$ & $\begin{array}{l}\text { Matou a mulher, por } \\
\text { ciúmes, passando sete } \\
\text { anos na Cadeia de } \\
\text { Campinas, onde tinha } \\
\text { bom comportamento. } \\
\text { Porém, tornou-se ner- } \\
\text { voso e foi transferido } \\
\text { para a Penitenciária do } \\
\text { Estado. }\end{array}$ \\
\hline DAP 062 & A.M.V. & M & 26 & Branca & Brasileira & & Casado & Soldado & Católica & $\begin{array}{l}\text { Alfabetizado } \\
\text { (rudimentar) }\end{array}$ & $\begin{array}{l}\text { Bragança, } \\
\text { SP }\end{array}$ & $10 / 3 / 1924$ & $1 / 9 / 1925$ & Alta & & $\begin{array}{l}\text { Não teve } \\
\text { alteração das } \\
\text { faculdades } \\
\text { mentais }\end{array}$ & $\begin{array}{l}\text { Réu, por } \\
\text { homicídio. }\end{array}$ & $\begin{array}{l}\text { Preso, após cometer } \\
\text { vários roubos. } \\
\text { Desentendimentos na } \\
\text { cadeia fizeram com } \\
\text { que fosse removido ao } \\
\text { manicômio. }\end{array}$ \\
\hline DAP 047A & A.A. & M & 23 & Parda & Brasileira & $\begin{array}{l}\text { Pernam- } \\
\text { buco }\end{array}$ & Solteiro & Lavrador & & & & $10 / 6 / 1924$ & 4/20/1967 & $\begin{array}{l}\text { Trans- } \\
\text { ferência } \\
\text { para o } \\
\text { Hospital } \\
\text { do Ju- } \\
\text { query }\end{array}$ & Fotografia & $\begin{array}{l}\text { Demência } \\
\text { precoce e } \\
\text { esquizofrenia }\end{array}$ & $\begin{array}{l}\text { Réu, por } \\
\text { estuprar } \\
\text { uma } \\
\text { menina de } \\
\text { ll anos. }\end{array}$ & $\begin{array}{l}\text { Questionário familiar } \\
\text { respondido pelo diretor } \\
\text { do hospital. Cópia de } \\
\text { partes do processo } \\
\text { crime. Sofria de tristeza } \\
\text { excessiva na peniten- } \\
\text { ciária. }\end{array}$ \\
\hline DAP 273A & J.P. & M & 13 & Branca & Brasileira & $\begin{array}{l}\text { São Pau- } \\
\text { lo, SP }\end{array}$ & Solteiro & $\begin{array}{l}\text { Vendedor } \\
\text { de jornais }\end{array}$ & & & $\begin{array}{l}\text { Instituto } \\
\text { Disciplinar }\end{array}$ & $12 / 17 / 1924$ & 6/16/1946 & Óbito & & $\begin{array}{l}\text { Epilepsia } \\
\text { encefalógena, } \\
\text { imbecilidade. }\end{array}$ & & $\begin{array}{l}\text { Ficha e oficio de iden- } \\
\text { tificacaão do Instituto } \\
\text { Disciplinar da Capital, } \\
\text { de onde foi transferido } \\
\text { para o Hospital do } \\
\text { Juquery. Seu delito } \\
\text { fora "pedir esmolas" e, } \\
\text { na ficha do instituto, } \\
\text { pede-se que ele fique } \\
\text { recluso, até completar } \\
\text { a maioridade. }\end{array}$ \\
\hline DAP 235 & J.B. & M & 32 & Branca & Síria & Síria & Solteiro & $\begin{array}{l}\text { Comer- } \\
\text { ciante }\end{array}$ & & & $\begin{array}{l}\text { Araraqua- } \\
\text { ra, SP }\end{array}$ & $1 / 1 / 1925$ & & & & $\begin{array}{l}\text { Demência } \\
\text { precoce hebe- } \\
\text { frênica }\end{array}$ & $\begin{array}{l}\text { Acusado } \\
\text { de matar a } \\
\text { irmã (art. } \\
\text { 294). }\end{array}$ & \\
\hline
\end{tabular}




\begin{tabular}{|c|c|c|c|c|c|c|c|c|c|c|c|c|c|c|c|c|c|c|}
\hline 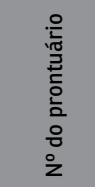 & 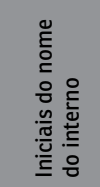 & 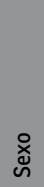 & $\begin{array}{l}\frac{\pi}{\pi} \\
\frac{\pi}{0}\end{array}$ & ¿̀ & 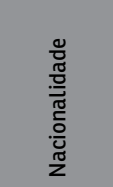 & 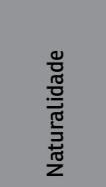 & 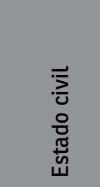 & 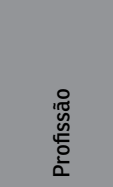 & 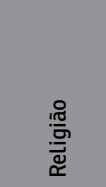 & 㝕 & 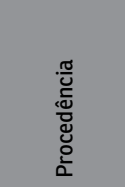 & 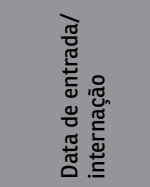 & 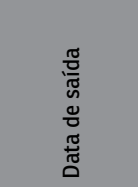 & 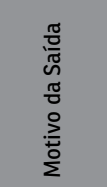 & 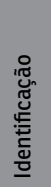 & 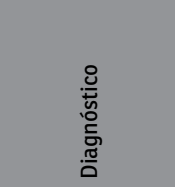 & 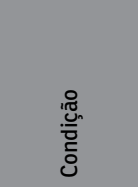 & 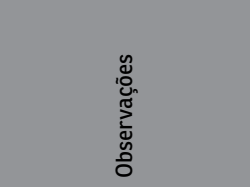 \\
\hline DAP 325 & O.J.F. & M & 30 & Parda & Brasileira & & Solteiro & Operário & Católica & Alfabetizado & $\begin{array}{l}\text { São João } \\
\text { da Boa } \\
\text { Vista, SP }\end{array}$ & $\begin{array}{l}24 / 03 / 1921 \text { e } \\
25 / 01 / 1925\end{array}$ & $\begin{array}{l}08 / 03 / 1923 \\
\mathrm{e} \\
30 / 03 / 1927\end{array}$ & Óbito & & $\begin{array}{l}\text { Depressão me- } \\
\text { lancólica, debi- } \\
\text { lidade mental, } \\
\text { alcoolista. }\end{array}$ & Réu & $\begin{array}{l}\text { Paralisia e encurta- } \\
\text { mento da perna direita. } \\
\text { Problemas com álcool, } \\
\text { tendo confessado-os, } \\
\text { em sua segunda en- } \\
\text { trada. Questionário do } \\
\text { hospital respondido por } \\
\text { seu cunhado. Não há o } \\
\text { prontuário da primeira } \\
\text { internação, dada pelos } \\
\text { relatos médicos. }\end{array}$ \\
\hline DAP 130 & D.C. & M & 36 & Branca & Brasileira & & Casado & Barbeiro & Católica & & $\begin{array}{l}\text { Cadeia } \\
\text { Pública da } \\
\text { Capital, } \\
\text { SP }\end{array}$ & 2/19/1925 & $2 / 25 / 2025$ & & & $\begin{array}{l}\text { Quadro esqui- } \\
\text { zofrênico de } \\
\text { Bleuler }\end{array}$ & Réu & $\begin{array}{l}\text { Não há descrição } \\
\text { do crime, apenas os } \\
\text { exames médicos. }\end{array}$ \\
\hline DAP 107 & c.s. & M & 48 & Branca & Italiana & $\begin{array}{l}\text { Veneza, } \\
\text { Itália }\end{array}$ & Casado & Lavrador & Católica & Alfabetizado & $\begin{array}{l}\text { Peniten- } \\
\text { ciária do } \\
\text { Estado, } \\
\text { SP }\end{array}$ & 2/28/1925 & $5 / 30 / 1944$ & Óbito & & $\begin{array}{l}\text { Psicose maní- } \\
\text { aco-depressiva } \\
\text { (melancolia } \\
\text { predominante) }\end{array}$ & $\begin{array}{l}\text { Acusado de } \\
\text { homicídio } \\
\text { brutal. }\end{array}$ & $\begin{array}{l}\text { Seu estado, na peniten- } \\
\text { ciária, piorou, ao saber } \\
\text { que sua mulher se } \\
\text { casou novamente; junto } \\
\text { com o incômodo cau- } \\
\text { sado pela Revolução } \\
\text { de 1930, que aparece } \\
\text { descrito no prontuário. }\end{array}$ \\
\hline DAP 128 & D.S. & M & 19 & Branca & Brasileira & & & Lavrador & & & $\begin{array}{l}\text { Peniten- } \\
\text { ciária de } \\
\text { Jabotica- } \\
\text { bal, SP }\end{array}$ & 3/10/1925 & 8/11/2025 & & & $\begin{array}{l}\text { Não sofre das } \\
\text { faculdades } \\
\text { mentais }\end{array}$ & $\begin{array}{l}\text { Acusado de } \\
\text { assassinar } \\
\text { o tio, com } \\
\text { dois tiros. }\end{array}$ & $\begin{array}{l}\text { Recolhido ao hospício } \\
\text { por apresentar um } \\
\text { comportamento consi- } \\
\text { derado estranho. }\end{array}$ \\
\hline DAP 236 & J.c. & M & 26 & Branca & Brasileira & $\begin{array}{l}\text { São Pau- } \\
\text { Lo, SP }\end{array}$ & Solteiro & $\begin{array}{l}\text { Serven- } \\
\text { te de } \\
\text { pedreiro }\end{array}$ & & & $\begin{array}{l}\text { Cadeia } \\
\text { Pública da } \\
\text { Capital, } \\
\text { SP }\end{array}$ & $4 / 9 / 1925$ & 7/11/1961 & $\begin{array}{l}\text { Trans- } \\
\text { ferência } \\
\text { para o } \\
\text { Hospital } \\
\text { do Ju- } \\
\text { query }\end{array}$ & & Esquizofrenia & $\begin{array}{l}\text { Réu, } \\
\text { acusado } \\
\text { de matar a } \\
\text { mãe }\end{array}$ & \\
\hline DAP 346 & P.R.S. & M & 24 & Branca & Brasileira & Bahia & Casado & $\begin{array}{l}\text { Praça } \\
\text { da Força } \\
\text { Pública/ } \\
\text { soldado }\end{array}$ & & Alfabetizado & $\begin{array}{l}\text { Batatais, } \\
\text { SP }\end{array}$ & $4 / 30 / 1925$ & & & & $\begin{array}{l}\text { Demência } \\
\text { precoce }\end{array}$ & $\begin{array}{l}\text { Réu, enca- } \\
\text { minhado } \\
\text { para exame } \\
\text { de sanida- } \\
\text { de mental. } \\
\text { Preso por } \\
\text { homicídio } \\
\text { (arts. 294, } \\
1^{\circ} \text { e } 303 \text { ). }\end{array}$ & $\begin{array}{l}\text { A cor também aparece } \\
\text { como parda. Cópia dos } \\
\text { depoimentos. Carta da } \\
\text { mulher do paciente. }\end{array}$ \\
\hline
\end{tabular}




\begin{tabular}{|c|c|c|c|c|c|c|c|c|c|c|c|c|c|c|c|c|c|c|}
\hline 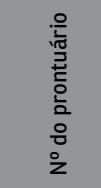 & 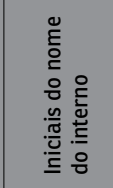 & ๙̊̀ & $\begin{array}{l}\text { 帝 } \\
\text { 元 }\end{array}$ & ¿̀̀ & 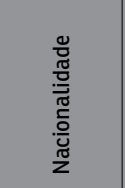 & 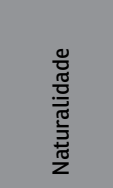 & 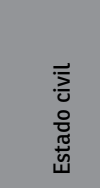 & 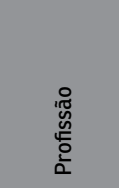 & 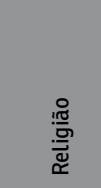 & 兽 & 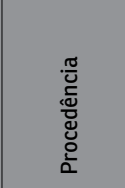 & 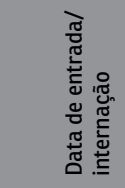 & 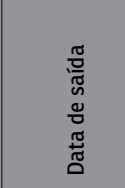 & 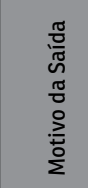 & 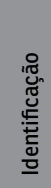 & 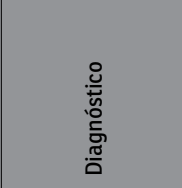 & 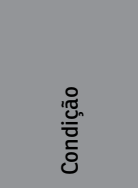 & 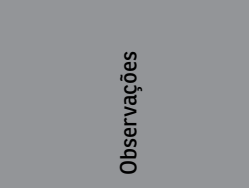 \\
\hline DAP 329 & P.P. & $M$ & 32 & Branca & Italiana & $\begin{array}{l}\text { Caserta, } \\
\text { Itália }\end{array}$ & Solteiro & Alfaiate & & & $\begin{array}{l}\text { Cadeia } \\
\text { Pública da } \\
\text { Capital, } \\
\text { SP }\end{array}$ & $5 / 24 / 1925$ & 2/27/1961 & Óbito & & $\begin{array}{l}\text { Neurosíflis, } \\
\text { sindrome pa- } \\
\text { ranoide, deficit } \\
\text { de julgamento, } \\
\text { hipocon- } \\
\text { dria, ideias } \\
\text { delirantes e de } \\
\text { perseguição. } \\
\end{array}$ & Réu & \\
\hline DAP 226 & J.P.F. & M & 70 & Branca & $\begin{array}{l}\text { Portu- } \\
\text { guesa }\end{array}$ & & Viúvo & Cambista & & Alfabetizado & \begin{tabular}{|l} 
Rio Claro, \\
SP
\end{tabular} & $6 / 3 / 1925$ & & & & $\begin{array}{l}\text { Psicose de } \\
\text { involução }\end{array}$ & Réu & $\begin{array}{l}\text { Tinha sensação de } \\
\text { perseguiçāo, tendo } \\
\text { mudado várias vezes } \\
\text { para fugir, mas sempre } \\
\text { sendo seguido. Um dia, } \\
\text { ao ouvir uma batida } \\
\text { na porta, atirou contra } \\
\text { ela, matando um ino- } \\
\text { cente. No decorrer do } \\
\text { processo, aparece como } \\
\text { brasileiro. }\end{array}$ \\
\hline DAP 17 & A.C. & M & 35 & Parda & Brasileira & $\begin{array}{l}\text { Alagoa } \\
\text { Grande, } \\
\text { PB }\end{array}$ & Solteiro & $\begin{array}{l}\text { Lavrador, } \\
\text { jorna- } \\
\text { leiro, } \\
\text { Marinha } \\
\text { de Guerra }\end{array}$ & Católica & Alfabetizado & $\begin{array}{l}\text { Peniten- } \\
\text { ciária do } \\
\text { Estado, } \\
\text { SP }\end{array}$ & $6 / 18 / 1925$ & & & & $\begin{array}{l}\text { Demência } \\
\text { precoce }\end{array}$ & $\begin{array}{l}\text { Réu por } \\
\text { homicídio. } \\
\text { Condenado } \\
\text { a } 15 \text { anos. }\end{array}$ & $\begin{array}{l}\text { Serviu na Marinha de } \\
\text { Guerra. Após a baixa, } \\
\text { tornou-se trabalhador } \\
\text { braçal. A vítima foi uma } \\
\text { mulher que não cedeu } \\
\text { às suas "crapulices } \\
\text { imorais". }\end{array}$ \\
\hline DAP 007 & A.T.S. & M & $\begin{array}{l}\text { Não } \\
\text { cons- } \\
\text { ta }\end{array}$ & Preta & Brasileira & & Viúvo & & & Analfabeto & $\begin{array}{l}\text { Jabotica- } \\
\text { bal, SP }\end{array}$ & $7 / 19 / 1925$ & & & & $\begin{array}{l}\text { Fraco de espíri- } \\
\text { to, determinado } \\
\text { pelo álcool e } \\
\text { traumatismo } \\
\text { craniano. }\end{array}$ & Réu & $\begin{array}{l}\text { Matou sua mulher, pois } \\
\text { ela não mostrou boa } \\
\text { vontade em fazer o } \\
\text { café. Tinha convul- } \\
\text { sōes e ataques, que o } \\
\text { deixavam "variado da } \\
\text { cabeça". }\end{array}$ \\
\hline DAP 208 & J.J. & $M$ & $\begin{array}{l}\text { Apa- } \\
\text { renta } \\
35-36\end{array}$ & Parda & Brasileira & $\begin{array}{l}\text { Cunha, } \\
\text { SP }\end{array}$ & Solteiro & & & Analfabeto & $\begin{array}{l}\text { Peniten- } \\
\text { ciária de } \\
\text { Cunha, SP } \\
\end{array}$ & $7 / 29 / 1925$ & & & & $\begin{array}{l}\text { Imbecil e } \\
\text { alcoolista }\end{array}$ & $\begin{array}{l}\text { Senten- } \\
\text { ciado }\end{array}$ & $\begin{array}{l}\text { Não há descrição } \\
\text { do crime, apenas os } \\
\text { exames médicos. }\end{array}$ \\
\hline DAP319 & o.s. & $\mathrm{F}$ & 25 & Preta & Brasileira & & Casada & $\begin{array}{l}\text { Serviços } \\
\text { domésti- } \\
\text { cos }\end{array}$ & Católica & Analfabeta & $\begin{array}{l}\text { Casa } \\
\text { Branca, SP }\end{array}$ & $8 / 2 / 1925$ & & & & $\begin{array}{l}\text { Demência } \\
\text { precoce }\end{array}$ & $\begin{array}{l}\text { Ré, por } \\
\text { homicídio } \\
\text { contra o } \\
\text { marido. }\end{array}$ & $\begin{array}{l}\text { Matou o marido a ma- } \\
\text { chadadas, pois ele foi } \\
\text { tirar satisfaçōes sobre a } \\
\text { educação dos filhos. }\end{array}$ \\
\hline DAP 295 & M.E.J.N. & $\mathrm{F}$ & 25 & Branca & $\begin{array}{l}\text { Portu- } \\
\text { guesa }\end{array}$ & & Casada & $\begin{array}{l}\text { Domés- } \\
\text { tica }\end{array}$ & Católica & & $\begin{array}{l}\text { São Paulo, } \\
\text { SP }\end{array}$ & $8 / 18 / 1925$ & & & & Parafrenia & & \\
\hline DAP 370 & S.P.R. & $M$ & 30 & Branca & Brasileira & $\begin{array}{l}\text { Guaxupé, } \\
\text { MG }\end{array}$ & Solteiro & Lavrador & Católica & $\begin{array}{l}\text { Alfabetizado } \\
\text { (rudimentar) }\end{array}$ & $\begin{array}{l}\text { Peniten- } \\
\text { ciária do } \\
\text { Estado, } \\
\text { SP }\end{array}$ & $10 / 2 / 1925$ & & & & $\begin{array}{l}\text { Demência } \\
\text { precoce }\end{array}$ & $\begin{array}{l}\text { Acusado de } \\
\text { homicídio. } \\
\text { Condenado } \\
\text { a } 16 \text { anos } \\
\text { e meio de } \\
\text { prisão. }\end{array}$ & \\
\hline
\end{tabular}




\begin{tabular}{|c|c|c|c|c|c|c|c|c|c|c|c|c|c|c|c|c|c|c|}
\hline 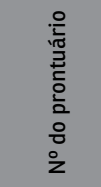 & 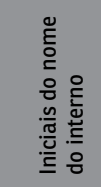 & ڤ̊̀̆ & $\begin{array}{l}\frac{\pi}{\pi} \\
\frac{\pi}{0}\end{array}$ & ¿̀ & $\begin{array}{l}\frac{\pi}{\pi} \\
\frac{\pi}{\pi} \\
\frac{\pi}{\pi} \\
\frac{0}{0} \\
\frac{\pi}{2}\end{array}$ & 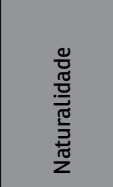 & 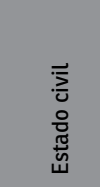 & 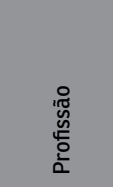 & $\begin{array}{l}: \frac{1}{7} \\
\frac{10}{\pi} \\
\frac{\pi}{\pi}\end{array}$ & 怘 & 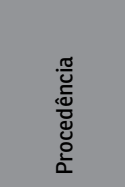 & 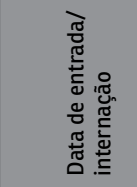 & 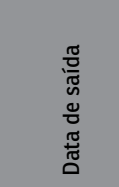 & 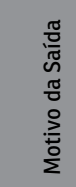 & 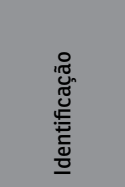 & 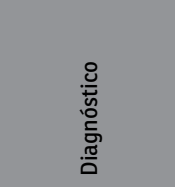 & 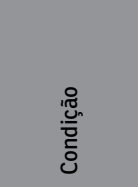 & 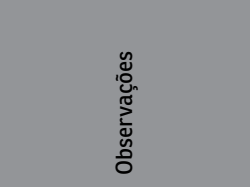 \\
\hline DAP 073 & A.V. & M & 48 & Branca & Italiana & & Solteiro & Operário & Católica & Analfabeto & $\begin{array}{l}\text { Cadeia } \\
\text { Pública da } \\
\text { Capital, } \\
\text { SP }\end{array}$ & $10 / 30 / 1925$ & & & & Parafrenia & Réu & $\begin{array}{l}\text { Matou o vizinho, após } \\
\text { uma agressão física. } \\
\text { Consta foto. Houve } \\
\text { tentativa de suicídio, } \\
\text { por isso foi internado } \\
\text { no Hospício do Rio } \\
\text { de Janeiro, em } 1910 \text {. } \\
\text { Após a alta, foi para } \\
\text { São Paulo. Histórico } \\
\text { de crises esporádicas, } \\
\text { temperamento agressi- } \\
\text { vo e brigas. }\end{array}$ \\
\hline DAP 033 & A.N. & M & 26 & Branca & Brasileira & Tatuí, SP & Viúvo & Lavrador & Católica & Alfabetizado & $\begin{array}{l}\text { Comarca } \\
\text { de Assis, } \\
\text { SP }\end{array}$ & $4 / 21 / 1926$ & $2 / 22 / 1938$ & Óbito & $\begin{array}{l}\text { Fotografia } \\
\text { e digitais }\end{array}$ & $\begin{array}{l}\text { Síndrome } \\
\text { paranoide }\end{array}$ & $\begin{array}{l}\text { Senten- } \\
\text { ciado (art. } \\
\left.291, \$ 1^{\circ}\right) \text {, } \\
\text { por crime } \\
\text { de homicí- } \\
\text { dio. }\end{array}$ & $\begin{array}{l}\text { Carta dizendo ser re- } \\
\text { primido por defender o } \\
\text { espiritismo. Desenhos: } \\
\text { de um cavalo com } \\
\text { vestimenta de bispo; } \\
\text { de um homem gritando } \\
\text { "espiritismo" enquanto } \\
\text { outro, vestido de cléri- } \\
\text { go, tem a legenda "ca- } \\
\text { tolicismo" ladeado por } \\
\text { um índio; pescador ao } \\
\text { lado de um cachorro, } \\
\text { com frase mencionando } \\
\text { Julio Prestes e Laurin- } \\
\text { do Manhoto [?]. }\end{array}$ \\
\hline DAP 050 & A.C.S. & M & 29 & Parda & Brasileira & $\begin{array}{l}\text { São Pau- } \\
\text { lo, SP }\end{array}$ & Solteiro & Lavrador & Católica & Analfabeto & $\begin{array}{l}\text { Peniten- } \\
\text { ciária do } \\
\text { Estado, } \\
\text { SP }\end{array}$ & $4 / 22 / 1926$ & & & Fotografia & $\begin{array}{l}\text { Psicose manía- } \\
\text { co-depressiva, } \\
\text { debilidade } \\
\text { mental. }\end{array}$ & $\begin{array}{l}\text { Senten- } \\
\text { ciado, por } \\
\text { crime de } \\
\text { estupro. }\end{array}$ & \\
\hline DAP 010 & A.L. & M & 44 & Branca & Italiana & $\begin{array}{l}\text { Sant'An- } \\
\text { na, Itália }\end{array}$ & Viúvo & $\begin{array}{l}\text { Vendedor } \\
\text { ambu- } \\
\text { lante }\end{array}$ & Católica & Analfabeto & $\begin{array}{l}\text { Cadeia } \\
\text { Pública da } \\
\text { Capital, } \\
\text { SP }\end{array}$ & 6/15/1926 & 10/1/1937 & Óbito & Fotografia & $\begin{array}{l}\text { Demência pre- } \\
\text { coce paranoide }\end{array}$ & $\begin{array}{l}\text { Sentencia- } \\
\text { do (art. } 294 \\
\text { do Código } \\
\text { Penal, \$ } \\
2^{\circ} \text { ). }\end{array}$ & \\
\hline DAP 380 & T.F.R. & M & 25 & Branca & Brasileira & & Solteiro & & Católica & $\begin{array}{l}\text { Alfabetizado } \\
\text { (elementar) }\end{array}$ & $\begin{array}{l}\text { Cadeia } \\
\text { Pública da } \\
\text { Capital, } \\
\text { SP }\end{array}$ & 9/22/1926 & & & Fotografia & $\begin{array}{l}\text { Demência } \\
\text { precoce }\end{array}$ & $\begin{array}{l}\text { Réu, por } \\
\text { tentativa de } \\
\text { homicídio. }\end{array}$ & $\begin{array}{l}\text { Entrou como indigente. } \\
\text { Não aparenta ser } \\
\text { branco na foto, apesar } \\
\text { de ter sido assim } \\
\text { classificado. }\end{array}$ \\
\hline DAP 211 & J.M.G. & M & 22 & Branca & Brasileira & & Viúvo & Operário & & $\begin{array}{l}\text { Alfabetizado } \\
\text { (sabe ler) }\end{array}$ & $\begin{array}{l}\text { Cadeia } \\
\text { Pública da } \\
\text { Capital, } \\
\text { SP }\end{array}$ & $12 / 16 / 1926$ & 9/30/1927 & & Fotografia & $\begin{array}{l}\text { Encefalopatia } \\
\text { infantil, com } \\
\text { sequelas } \\
\text { psíquicas }\end{array}$ & $\begin{array}{l}\text { Senten- } \\
\text { ciado, por } \\
\text { homicidio } \\
\text { contra a } \\
\text { esposa. }\end{array}$ & \\
\hline DAP 070 & A.S. & M & 22 & Branca & $\begin{array}{l}\text { Argen- } \\
\text { tina }\end{array}$ & & Solteiro & Operário & Católica & $\begin{array}{l}\text { Analfabeto } \\
\text { (quase) }\end{array}$ & $\begin{array}{l}\text { Cadeia } \\
\text { Pública da } \\
\text { Capital, } \\
\text { SP }\end{array}$ & $1 / 6 / 1927$ & & & Fotografia & $\begin{array}{l}\text { Síndrome } \\
\text { paranoide }\end{array}$ & $\begin{array}{l}\text { Réu, por } \\
\text { homicídio. }\end{array}$ & $\begin{array}{l}\text { Não apresenta } \\
\text { alteraçōes em suas } \\
\text { faculdades mentais, em } \\
\text { um primeiro momento. }\end{array}$ \\
\hline
\end{tabular}




\begin{tabular}{|c|c|c|c|c|c|c|c|c|c|c|c|c|c|c|c|c|c|c|}
\hline 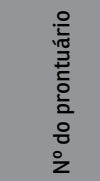 & 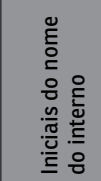 & હ্̊ & $\begin{array}{l}\text { 苋 } \\
\text { 五 }\end{array}$ & ¿̀ & 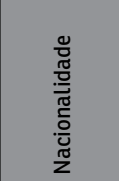 & 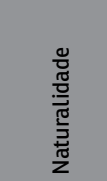 & 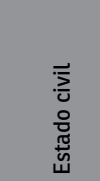 & 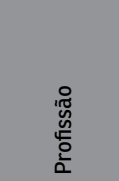 & $\begin{array}{l}\frac{0}{\pi} \\
\frac{\pi}{\pi} \\
\frac{\pi}{\pi} \\
\frac{\pi}{\pi}\end{array}$ & 苞 & 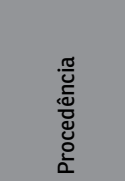 & 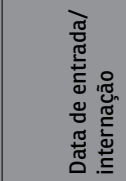 & $\begin{array}{l}\frac{\pi}{0} \\
\frac{0}{5} \\
\frac{\pi}{\pi} \\
\frac{\pi}{\pi} \\
0\end{array}$ & 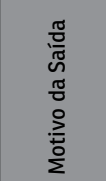 & 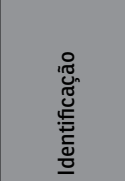 & 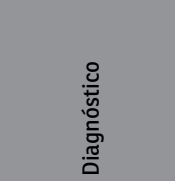 & 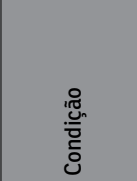 & 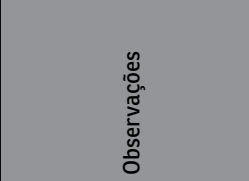 \\
\hline DAP 275 & K.M. & M & & $\begin{array}{l}\text { Ama- } \\
\text { rela }\end{array}$ & Japonesa & & Viúvo & & & & $\begin{array}{l}\text { Cadeia } \\
\text { Pública de } \\
\text { Penápolis, } \\
\text { SP }\end{array}$ & $1 / 9 / 1927$ & $2 / 2 / 1932$ & $\begin{array}{l}\text { Trans- } \\
\text { ferência } \\
\text { para o } \\
\text { Hospital } \\
\text { do Ju- } \\
\text { query }\end{array}$ & Fotografia & $\begin{array}{l}\text { Demência } \\
\text { precoce }\end{array}$ & $\begin{array}{l}\text { Réu por } \\
\text { homicídio } \\
\text { de sua } \\
\text { mulher e } \\
\text { seus quatro } \\
\text { filhos. }\end{array}$ & $\begin{array}{l}\text { Cópia de partes do pro- } \\
\text { cesso crime, recortes } \\
\text { de jornais e fotografia } \\
\text { da cena do crime. }\end{array}$ \\
\hline DAP 060 & A.J.S. & $M$ & 20 & Branca & Brasileira & $\begin{array}{l}\text { Urandi, } \\
\text { BA }\end{array}$ & Solteiro & Lavrador & Católica & $\begin{array}{l}\text { Alfabetizado } \\
\text { (elementar) }\end{array}$ & $\begin{array}{l}\text { Peniten- } \\
\text { ciária de } \\
\text { Sertāozi- } \\
\text { nho, SP }\end{array}$ & $3 / 23 / 1927$ & $2 / 2 / 1932$ & $\begin{array}{l}\text { Trans- } \\
\text { ferência } \\
\text { para o } \\
\text { Hospital } \\
\text { do Ju- } \\
\text { query }\end{array}$ & Fotografia & $\begin{array}{l}\text { Débil mental, } \\
\text { maníaco-de- } \\
\text { pressivo }\end{array}$ & $\begin{array}{l}\text { Réu, por } \\
\text { homicídio. }\end{array}$ & $\begin{array}{l}\text { Ficha do serviço psiqui- } \\
\text { átrico da Penitenciária } \\
\text { do Estado de São Paulo. }\end{array}$ \\
\hline DAP 086 & B.c.S. & M & 31 & Parda & Brasileira & & Casado & $\begin{array}{l}\text { Tenente } \\
\text { da Forçaa } \\
\text { Pública } \\
\text { (ex) }\end{array}$ & Católica & $\begin{array}{l}\text { Alfabetizado } \\
\text { (secundário) }\end{array}$ & $\begin{array}{l}\text { Cadeia } \\
\text { Pública da } \\
\text { Capital, } \\
\text { SP }\end{array}$ & $5 / 4 / 1927$ & & & & Sífilis nervosa & $\begin{array}{l}\text { Condenado } \\
\text { por utilizar } \\
\text { sua farda } \\
\text { para obter } \\
\text { "lucros } \\
\text { ilícitos", } \\
\text { coagindo } \\
\text { mulheres. }\end{array}$ & \\
\hline DAP 278 & L.M.C. & M & 40 & Preta & Brasileira & $\begin{array}{l}\text { Capivari, } \\
\text { SP }\end{array}$ & Viúvo & Lavrador & Católica & Analfabeto & $\begin{array}{l}\text { Cadeia } \\
\text { Pública de } \\
\text { Capivari, } \\
\text { SP }\end{array}$ & $5 / 18 / 1927$ & $3 / 5 / 1936$ & \begin{tabular}{|l|} 
Trans- \\
ferência \\
para a \\
Peniten- \\
ciária do \\
Estado
\end{tabular} & Fotografia & $\begin{array}{l}\text { Síndrome } \\
\text { paranoide }\end{array}$ & $\begin{array}{l}\text { Réu, por } \\
\text { homicídio } \\
\text { contra a } \\
\text { esposa. }\end{array}$ & $\begin{array}{l}\text { Filho de escravos } \\
\text { libertados em } 1888 . \\
\text { Recortes de jornal. }\end{array}$ \\
\hline DAP 077 & B.F. & M & 28 & Branca & Brasileira & & Solteiro & $\begin{array}{l}\text { Soldado } \\
\text { da Força } \\
\text { Pública }\end{array}$ & Católica & Alfabetizado & $\begin{array}{l}\text { Cadeia } \\
\text { Pública da } \\
\text { Capital, } \\
\text { SP }\end{array}$ & $5 / 18 / 1927$ & $8 / 14 / 1951$ & \begin{tabular}{|l|} 
Trans- \\
ferência \\
para o \\
Hospital \\
do Ju- \\
query
\end{tabular} & $\begin{array}{l}\text { Fotografia } \\
\text { e digitais }\end{array}$ & $\begin{array}{l}\text { Demência pre- } \\
\text { coce, debilidade } \\
\text { mental, surtos } \\
\text { delirantes, } \\
\text { esquizofrenia. }\end{array}$ & $\begin{array}{l}\text { Réu, por } \\
\text { homicídio. }\end{array}$ & $\begin{array}{l}\text { Avaliação psiquiátrica } \\
\text { da Penitenciária do } \\
\text { Estado. }\end{array}$ \\
\hline DAP 199 & J.c. & M & 19 & Branca & Brasileira & $\begin{array}{l}\text { Mairin- } \\
\text { que, SP }\end{array}$ & Solteiro & Operário & Católica & Alfabetizado & $\begin{array}{l}\text { Cadeia } \\
\text { Pública da } \\
\text { Capital, } \\
\text { SP }\end{array}$ & $7 / 31 / 1927$ & $10 / 3 / 1961$ & $\begin{array}{l}\text { Trans- } \\
\text { ferência } \\
\text { para o } \\
\text { Hospital } \\
\text { do Ju- } \\
\text { query }\end{array}$ & Fotografia & $\begin{array}{l}\text { Debilidade } \\
\text { mental e esqui- } \\
\text { zofrenia }\end{array}$ & $\begin{array}{l}\text { Réu, por } \\
\text { homicídio } \\
\text { contra o } \\
\text { pai. }\end{array}$ & $\begin{array}{l}\text { Cópia de partes do } \\
\text { processo criminal. } \\
\text { Diversas vezes, foi } \\
\text { transferido para o } \\
\text { Hospital Psiquiátrico } \\
\text { do Juquery; algumas } \\
\text { em virtude de não } \\
\text { apresentar riscos. }\end{array}$ \\
\hline DAP 021 & A.M. & M & 42 & Branca & Brasileira & & Casado & $\begin{array}{l}\text { Militar } \\
\text { reforma- } \\
\text { do }\end{array}$ & Católica & $\begin{array}{l}\text { Alfabetizado } \\
\text { (secundário) }\end{array}$ & $\begin{array}{l}\text { Cadeia } \\
\text { Pública da } \\
\text { Capital, } \\
\text { SP }\end{array}$ & $8 / 25 / 1927$ & 9/17/1927 & Alta & & $\begin{array}{l}\text { Não apresentou } \\
\text { transtorno } \\
\text { psíquico }\end{array}$ & Réu & $\begin{array}{l}\text { Sem delito relatado, } \\
\text { permaneceu internado } \\
\text { por pouco mais de duas } \\
\text { semanas, a fim de fazer } \\
\text { exames psíquicos. }\end{array}$ \\
\hline DAP 190 & J.A.C. & M & 34 & Branca & Brasileira & & Casado & Advogado & Católica & $\begin{array}{l}\text { Alfabetizado } \\
\text { (superior) }\end{array}$ & $\begin{array}{l}\text { Cadeia } \\
\text { Pública da } \\
\text { Capital, } \\
\text { SP }\end{array}$ & $9 / 2 / 1927$ & $9 / 30 / 1927$ & \begin{tabular}{|l|} 
Trans- \\
ferência \\
para a \\
Cadeia \\
Pública
\end{tabular} & & $\begin{array}{l}\text { Não apresentou } \\
\text { transtorno } \\
\text { psíquico }\end{array}$ & Réu & \\
\hline
\end{tabular}




\begin{tabular}{|c|c|c|c|c|c|c|c|c|c|c|c|c|c|c|c|c|c|c|}
\hline 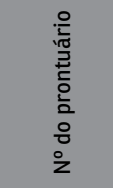 & 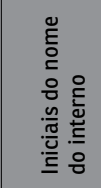 & ঙ્̊ & $\begin{array}{l}\text { 营 } \\
\text { 음 }\end{array}$ & ¿̀ & 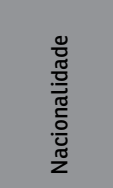 & 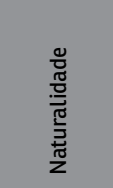 & 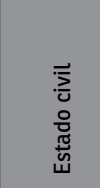 & 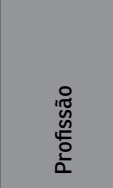 & 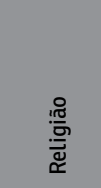 & 总 & 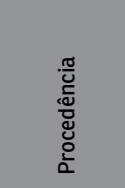 & 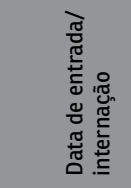 & 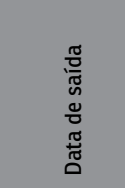 & 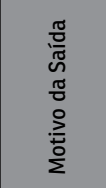 & 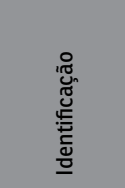 & 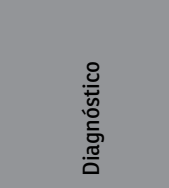 & 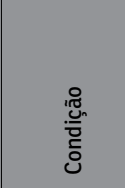 & 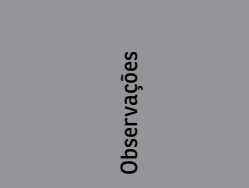 \\
\hline DAP 105 & C.B. & M & 32 & Branca & Italiana & & Solteiro & & Católica & Analfabeto & $\begin{array}{l}\text { Cadeia } \\
\text { Pública da } \\
\text { Capital, } \\
\text { SP }\end{array}$ & 9/2/1927 & 9/30/1927 & Alta & & $\begin{array}{l}\text { Síndrome } \\
\text { melancólica }\end{array}$ & Réu & $\begin{array}{l}\text { Observação, no } \\
\text { prontuário, afirma } \\
\text { ser necessário lhe } \\
\text { dar "proveitosa assis- } \\
\text { tência". }\end{array}$ \\
\hline DAP 048 & A.B. & M & 50 & Branca & Italiana & & Viúvo & & Católica & $\begin{array}{l}\text { Alfabetizado } \\
\text { (primário) }\end{array}$ & $\begin{array}{l}\text { Cadeia } \\
\text { Pública } \\
\text { de Salto } \\
\text { Grande, } \\
\text { SP } \\
\end{array}$ & 9/17/1927 & $2 / 10 / 1937$ & Óbito & Fotografia & $\begin{array}{l}\text { Síndrome } \\
\text { melancólica }\end{array}$ & Réu & $\begin{array}{l}\text { Cópia de partes do } \\
\text { processo criminal e au- } \\
\text { tópsia. Desferiu facadas } \\
\text { em um amigo. }\end{array}$ \\
\hline DAP 184 & J.C. & M & 41 & Branca & Italiana & & Casado & & & & $\begin{array}{l}\text { Cadeia } \\
\text { Pública da } \\
\text { Capital, } \\
\text { SP }\end{array}$ & $12 / 24 / 1927$ & $1 / 31 / 1929$ & Óbito & Fotografia & Paralisia geral & Réu & \\
\hline DAP 143 & E.B. & M & 31 & Branca & Francesa & & Solteiro & & & & $\begin{array}{l}\text { Cadeia } \\
\text { Pública da } \\
\text { Capital, } \\
\text { SP }\end{array}$ & $12 / 24 / 1927$ & $1 / 19 / 1928$ & Fuga & & & Réu & $\begin{array}{l}\text { Constam fuga e poucas } \\
\text { informaçōes sobre seu } \\
\text { estado mental, quando } \\
\text { internado. }\end{array}$ \\
\hline DAP 272 & J.B.F. & M & 29 & Branca & Brasileira & & Solteiro & Professor & & $\begin{array}{l}\text { Alfabetizado } \\
\text { (secundário) }\end{array}$ & $\begin{array}{l}\text { Itapetinin- } \\
\text { ga, SP }\end{array}$ & $2 / 7 / 1928$ & & & & & & $\begin{array}{l}\text { Internado por familia- } \\
\text { res, devido a problemas } \\
\text { com álcool, tendo dado } \\
\text { entrada em estado de } \\
\text { embriaguez. Carta do } \\
\text { pai do interno, ao dire- } \\
\text { tor do manicômio, no } \\
\text { qual afirma que o filho } \\
\text { queria suicidar-se. }\end{array}$ \\
\hline DAP 087 & B.C. & M & 28 & Preta & Brasileira & $\begin{array}{l}\text { Guara- } \\
\text { tinguetá, } \\
\text { SP }\end{array}$ & Casado & $\begin{array}{l}\text { Jorna- } \\
\text { leiro, } \\
\text { lavrador }\end{array}$ & Católica & Analfabeto & $\begin{array}{l}\text { Cadeia de } \\
\text { Igarapava, } \\
\text { SP }\end{array}$ & $3 / 18 / 1928$ & $12 / 20 / 1931$ & Óbito & & $\begin{array}{l}\text { Demência } \\
\text { precoce }\end{array}$ & $\begin{array}{l}\text { Réu (art. } \\
294, \text { S2; } \\
\text { art. } 13 \mathrm{e} \\
\text { art. } 63 \text { do } \\
\text { Código } \\
\text { Penal). }\end{array}$ & $\begin{array}{l}\text { Confessou sofrer de } \\
\text { abusos alcoóticos. } \\
\text { Cópia de partes do } \\
\text { processo criminal. }\end{array}$ \\
\hline DAP 032 & A.M.C. & M & 32 & Branca & Brasileira & & Casado & Portador & Católica & $\begin{array}{l}\text { Alfabetizado } \\
\text { (primário) }\end{array}$ & $\begin{array}{l}\text { Cadeia } \\
\text { Pública da } \\
\text { Capital, } \\
\text { SP } \\
\end{array}$ & $9 / 20 / 1928$ & $10 / 10 / 1928$ & $\begin{array}{l}\text { Não foi } \\
\text { diagnos- } \\
\text { ticado }\end{array}$ & & $\begin{array}{l}\text { Psicose epilép- } \\
\text { tica (suspeita } \\
\text { de) }\end{array}$ & Réu & $\begin{array}{l}\text { Permaneceu na } \\
\text { instituição por apenas } \\
\text { vinte dias, devido à } \\
\text { superlotaçāo. }\end{array}$ \\
\hline DAP 0244 & J.F. & M & 29 & Branca & Brasileira & $\begin{array}{l}\text { Mogi } \\
\text { Mirim, } \\
\text { SP }\end{array}$ & Solteiro & $\begin{array}{l}\text { Jorna- } \\
\text { leiro }\end{array}$ & & & $\begin{array}{l}\text { Mogi } \\
\text { Mirim, SP }\end{array}$ & $10 / 20 / 1928$ & $11 / 27 / 1945$ & Óbito & $\begin{array}{l}\text { Fotografia } \\
\text { e digitais }\end{array}$ & Esquizofrenia & $\begin{array}{l}\text { Absolvido, } \\
\text { art. } 27 \text { e } \\
\text { internado, } \\
\text { cf. Art. } 29 .\end{array}$ & $\begin{array}{l}\text { Faleceu sem causa } \\
\text { determinada, porém há } \\
\text { uma descriçāoo de um } \\
\text { "acentuado emagre- } \\
\text { cimento" e "queixa-se } \\
\text { de muita fraqueza". } \\
\text { Tratamento "tônico-re- } \\
\text { constituinte". Cópias de } \\
\text { documentos produzidos } \\
\text { na polícia. }\end{array}$ \\
\hline
\end{tabular}




\begin{tabular}{|c|c|c|c|c|c|c|c|c|c|c|c|c|c|c|c|c|c|c|}
\hline 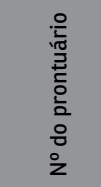 & 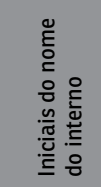 & §̊̀̀ & $\begin{array}{l}\text { 苋 } \\
\text { 吾 }\end{array}$ & ò & $\begin{array}{l}\frac{\pi}{\pi} \\
\frac{\pi}{\pi} \\
\frac{\pi}{\pi} \\
\frac{0}{0} \\
\frac{\pi}{2} \\
\frac{\pi}{2}\end{array}$ & 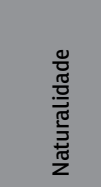 & 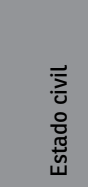 & 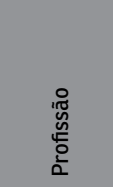 & $\frac{\sqrt{0}}{\square}$ & 㝕 & 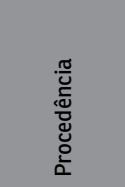 & 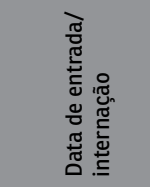 & 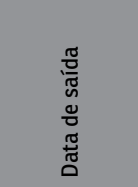 & 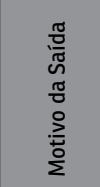 & 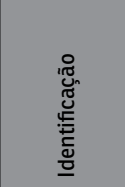 & 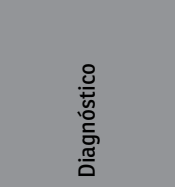 & 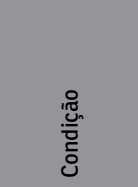 & 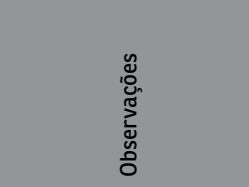 \\
\hline 16 & A. $S$ & M & 38 & Branca & Italiana & & Casado & & Católica & $\begin{array}{l}\text { Alfabetizado } \\
\text { (primário) }\end{array}$ & $\begin{array}{l}\text { Salute, } \\
\text { Itália }\end{array}$ & $1 / 15 / 1929$ & & & Fotografia & $\begin{array}{l}\text { Epilepsia } \\
\text { psíquica }\end{array}$ & $\begin{array}{l}\text { Réu, por } \\
\text { homicídio } \\
\text { contra o } \\
\text { pai. }\end{array}$ & $\begin{array}{l}\text { Matou o pai a tiros, por } \\
\text { ele exigir dinheiro. Irmã } \\
\text { internada no Juquery } \\
\text { por ter ideias suicidas. } \\
\text { O paciente também } \\
\text { tentou suicídio. Sofria } \\
\text { de alucinaçōes, que } \\
\text { envolviam a aparição } \\
\text { do pai e seu perdão. }\end{array}$ \\
\hline 123 & D. A & M & 36 & Preta & Brasileira & $\begin{array}{l}\text { Capão } \\
\text { Bonito, } \\
\text { SP }\end{array}$ & Viuvo & Lavrador & & Analfabeto & Santos, SP & $1 / 31 / 1929$ & $11 / 19 / 1933$ & Óbito & Fotografia & $\begin{array}{l}\text { Debilidade } \\
\text { mental com } \\
\text { surtos deli- } \\
\text { rantes }\end{array}$ & $\begin{array}{l}\text { Réu, por } \\
\text { homicídio } \\
\text { contra a } \\
\text { esposa. }\end{array}$ & $\begin{array}{l}\text { Acreditava que a } \\
\text { esposa o traía com } \\
\text { vários homens. Diz não } \\
\text { acreditar que a esposa } \\
\text { faleceu em razão das } \\
\text { agressōes e que, se } \\
\text { tivesse falecido, teria } \\
\text { aparecido, em espírito, } \\
\text { para ele, trajando a } \\
\text { roupa suja de sangue. }\end{array}$ \\
\hline DAP 168 & F.W. & M & 33 & Branca & Polonesa & Polônia & Viúvo & Mecânico & $\begin{array}{l}\text { Protes- } \\
\text { tante }\end{array}$ & $\begin{array}{l}\text { Alfabetizado } \\
\text { (primário) }\end{array}$ & $\begin{array}{l}\text { São Paulo, } \\
\text { SP }\end{array}$ & $\begin{array}{l}02 / 02 / 1929 \\
19 / 01 / 1940 \text { e } \\
13 / 06 / 1942\end{array}$ & $\begin{array}{l}03 / 03 / 1938 \\
25 / 07 / 1942 \\
\text { e } \\
25 / 07 / 1940\end{array}$ & $\begin{array}{l}\text { Trans- } \\
\text { ferência } \\
\text { para a } \\
\text { Cadeia } \\
\text { Pública }\end{array}$ & $\begin{array}{l}\text { Fotografia } \\
\text { e digitais }\end{array}$ & $\begin{array}{l}\text { Episódio psico- } \\
\text { pático }\end{array}$ & $\begin{array}{l}\text { Absolvido } \\
\text { (art. } 29 \text { do } \\
\text { Código Pe- } \\
\text { nal), pelo } \\
\text { homicídio } \\
\text { da esposa e } \\
\text { dos filhos. }\end{array}$ & $\begin{array}{l}\text { Três prontuários. } \\
\text { Registrado como de } \\
\text { nacionalidade norte-a- } \\
\text { mericana. Recorte de } \\
\text { jornal. }\end{array}$ \\
\hline DAP 312 & N.P.S. & M & 23 & Branca & Brasileira & & Casado & & Católica & & & $5 / 29 / 1929$ & $8 / 18 / 1929$ & & & & & \\
\hline DAP 237 & J.C.F. & M & 27 & Branca & Brasileira & & Viúvo & $\begin{array}{l}\text { Ex-sol- } \\
\text { dado da } \\
\text { Força } \\
\text { Pública }\end{array}$ & Católica & Alfabetizado & $\begin{array}{l}\text { São Paulo, } \\
\text { SP }\end{array}$ & $6 / 11 / 1929$ & $12 / 5 / 1935$ & Óbito & $\begin{array}{l}\text { Fotografia } \\
\text { e digitais }\end{array}$ & $\begin{array}{l}\text { Demência pre- } \\
\text { coce paranoide }\end{array}$ & $\begin{array}{l}\text { Réu, por } \\
\text { homicídio } \\
\text { contra a } \\
\text { esposa e a } \\
\text { sogra. }\end{array}$ & $\begin{array}{l}\text { Recorte de jornal e } \\
\text { carta de familiares. }\end{array}$ \\
\hline 144 & F. A & M & 40 & Branca & Síria & Síria & & & Católica & Alfabetizado & $\begin{array}{l}\text { Cadeia } \\
\text { Pública } \\
\text { do Estado, } \\
\text { SP }\end{array}$ & $7 / 2 / 1929$ & $9 / 12 / 1929$ & $\begin{array}{l}\text { Transfe- } \\
\text { rência }\end{array}$ & & $\begin{array}{l}\text { Alucinaçōes au- } \\
\text { ditivas e visuais } \\
\text { e delírios de } \\
\text { perseguição. }\end{array}$ & & $\begin{array}{l}\text { Afirmava que espíritos } \\
\text { queimavam-no, sorria } \\
\text { maliciosamente. Sem- } \\
\text { pre calmo. Pedia para } \\
\text { voltar à Cadeia Pública. }\end{array}$ \\
\hline DAP 386 & V.M. & M & 33 & Branca & Húngara & Hungria & Casado & $\begin{array}{l}\text { Marce- } \\
\text { neiro }\end{array}$ & & & $\begin{array}{l}\text { São Paulo, } \\
\text { SP }\end{array}$ & $7 / 4 / 1929$ & & & & & $\begin{array}{l}\text { Réu (art. } \\
294 \text { do Có- } \\
\text { digo Penal, } \\
\mathbb{S} 1^{\circ} \text {. }\end{array}$ & $\begin{array}{l}\text { Indigente. Não há } \\
\text { diagnóstico. Matou a } \\
\text { família do locador, que } \\
\text { perseguia os inquilinos. }\end{array}$ \\
\hline
\end{tabular}




\begin{tabular}{|c|c|c|c|c|c|c|c|c|c|c|c|c|c|c|c|c|c|c|}
\hline 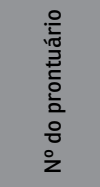 & 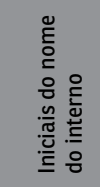 & ঙ̊̊̆ & $\begin{array}{l}\frac{8}{0} \\
\frac{\pi}{0}\end{array}$ & $\bar{u}$ & $\begin{array}{l}\frac{\pi}{\pi} \\
\frac{\pi}{\pi} \\
\frac{\pi}{\pi} \\
\frac{0}{0} \\
\frac{\pi}{2}\end{array}$ & 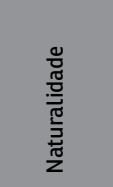 & 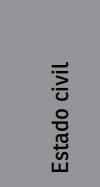 & 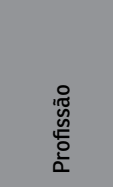 & : & 空 & 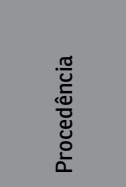 & 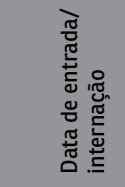 & $\begin{array}{l}\frac{\pi}{\pi} \\
\frac{\tilde{N}}{2} \\
\frac{0}{\pi} \\
\frac{\pi}{\pi} \\
\frac{\pi}{0}\end{array}$ & 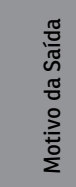 & 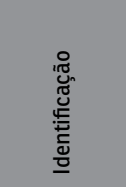 & 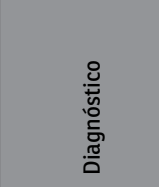 & 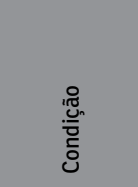 & 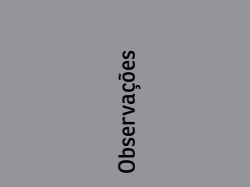 \\
\hline DAP 339 & P.B. & M & 36 & Branca & Italiana & $\begin{array}{l}\text { Reggio } \\
\text { da } \\
\text { Calábria, } \\
\text { Itália }\end{array}$ & Casado & $\begin{array}{l}\text { Empre- } \\
\text { gado do } \\
\text { comércio }\end{array}$ & & Alfabetizado & $\begin{array}{l}\text { São Paulo, } \\
\text { SP }\end{array}$ & $7 / 5 / 1929$ & $8 / 27 / 1929$ & & & & $\begin{array}{l}\text { Réu (art. } \\
294 \text { do Có- } \\
\text { digo Penal, } \\
\text { combinado } \\
\text { como o } \\
\text { art.13 e } \\
\text { art. } 63 \text { do } \\
\text { Código } \\
\text { Penal), por } \\
\text { tentativa de } \\
\text { homicídio. }\end{array}$ & \\
\hline DAP 332 & P.J. & M & 48 & Branca & Húngara & Hungria & Casado & Operário & Católica & Alfabetizado & $\begin{array}{l}\text { São Paulo, } \\
\text { SP }\end{array}$ & $7 / 24 / 1929$ & $8 / 31 / 1934$ & Óbito & $\begin{array}{l}\text { Fotografia } \\
\text { e assina- } \\
\text { tura }\end{array}$ & Sifilítico & $\begin{array}{l}\text { Sentencia- } \\
\text { do (art. 356 } \\
\text { e art. } 357 \\
\text { do Código } \\
\text { Penal), por } \\
\text { furto. }\end{array}$ & \\
\hline DAP 233 & J.B.A. & M & 43 & Preta & Brasileira & $\begin{array}{l}\text { Caçapa- } \\
\text { va, SP }\end{array}$ & Viúvo & & Católica & & $\begin{array}{l}\text { São Paulo, } \\
\text { SP }\end{array}$ & $7 / 24 / 1929$ & $4 / 21 / 1946$ & Óbito & $\begin{array}{l}\text { Fotografia } \\
\text { e digitais }\end{array}$ & Parafrenia & $\begin{array}{l}\text { Sub-má- } \\
\text { ximo (art. } \\
294 \text { do } \\
\text { Código } \\
\text { Penal, } \$ 1^{\circ} \\
\text { do Código } \\
\text { Penal). }\end{array}$ & \\
\hline 57 & A. F. S & M & 27 & Preta & Brasileira & $\begin{array}{l}\text { Paty do } \\
\text { Alferes, } \\
\text { RJ }\end{array}$ & Solteiro & & Católica & Analfabeto & $\begin{array}{l}\text { Peniten- } \\
\text { ciária do } \\
\text { Estado, } \\
\text { SP }\end{array}$ & 7/24/1929 & $6 / 22 / 1941$ & Óbito & $\begin{array}{l}\text { Fotografia } \\
\text { e digitais }\end{array}$ & $\begin{array}{l}\text { Demência } \\
\text { precoce }\end{array}$ & $\begin{array}{l}\text { Réu, por } \\
\text { homicídio } \\
\text { contra a } \\
\text { esposa. }\end{array}$ & $\begin{array}{l}\text { Crime contra um ho- } \\
\text { mem com quem travou } \\
\text { uma luta corporal, } \\
\text { ambos embriagados. }\end{array}$ \\
\hline 93 & B. J. $\mathrm{S}$ & M & 38 & Preta & Brasileira & $\begin{array}{l}\text { Campi- } \\
\text { nas, SP }\end{array}$ & Casado & Roceiro & Católica & & $\begin{array}{l}\text { Peniten- } \\
\text { ciária do } \\
\text { Estado, } \\
\text { SP }\end{array}$ & $7 / 24 / 1929$ & $4 / 28 / 1933$ & Óbito & $\begin{array}{l}\text { Fotografia } \\
\text { e digitais }\end{array}$ & Parafrenia & & $\begin{array}{l}\text { Afirma ser guiado por } \\
\text { espíritos. Escuta vozes } \\
\text { de quatro espíritos, que } \\
\text { controlam parte de seu } \\
\text { corpo. Afirma que isso } \\
\text { se deve à ascendência } \\
\text { paranormal de seus } \\
\text { pais. }\end{array}$ \\
\hline 135 & E. D & M & 39 & Branca & Brasileira & $\begin{array}{l}\text { São José } \\
\text { do Rio } \\
\text { Pardo, SP }\end{array}$ & Viuvo & Lavrador & Católica & Analfabeto & $\begin{array}{l}\text { Peniten- } \\
\text { ciária do } \\
\text { Estado, } \\
\text { SP }\end{array}$ & $7 / 24 / 1929$ & $5 / 9 / 1947$ & Óbito & $\begin{array}{l}\text { Fotografia } \\
\text { e digitais }\end{array}$ & $\begin{array}{l}\text { Debilidade } \\
\text { mental, para- } \\
\text { frenia. }\end{array}$ & $\begin{array}{l}\text { Réu, por } \\
\text { homicídio } \\
\text { contra a } \\
\text { esposa. }\end{array}$ & $\begin{array}{l}\text { Afirma ser príncipe ou } \\
\text { imperador. Afrma ter } \\
\text { perdido a stima pela } \\
\text { esposa, depois que ela } \\
\text { o desacatou e foi infiel. } \\
\text { Bem localizado no } \\
\text { tempo e no meio. }\end{array}$ \\
\hline DAP 185 & J.R. & M & 20 & Parda & Brasileira & $\begin{array}{l}\text { Serro, } \\
\text { MG }\end{array}$ & Solteiro & $\begin{array}{l}\text { Jorna- } \\
\text { leiro }\end{array}$ & & Alfabetizado & Santos, SP & 8/17/1929 & $7 / 30 / 1930$ & & Fotografia & & $\begin{array}{l}\text { Senten- } \\
\text { ciado }\end{array}$ & \\
\hline
\end{tabular}




\begin{tabular}{|c|c|c|c|c|c|c|c|c|c|c|c|c|c|c|c|c|c|c|}
\hline 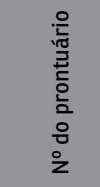 & 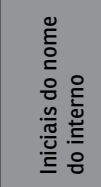 & ঙ̊̊̀̊ & $\begin{array}{l}\text { 范 } \\
\text { 吾 }\end{array}$ & ¿̀ & $\begin{array}{l}\frac{\pi}{\pi} \\
\frac{\pi}{\pi} \\
\frac{\pi}{\pi} \\
\frac{0}{\bar{J}} \\
\frac{\pi}{2}\end{array}$ & 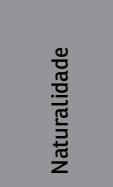 & 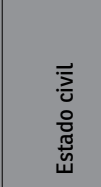 & 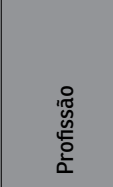 & $\begin{array}{l}: \frac{1}{5} \\
\frac{10}{\bar{\Xi}} \\
\frac{\pi}{\pi}\end{array}$ & 突 & 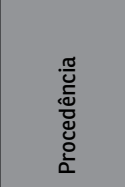 & 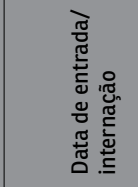 & 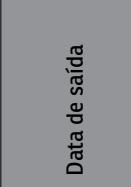 & 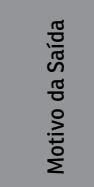 & 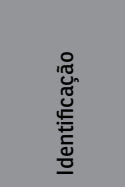 & 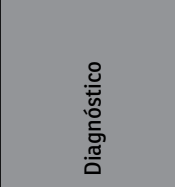 & 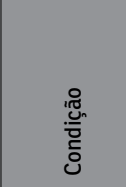 & 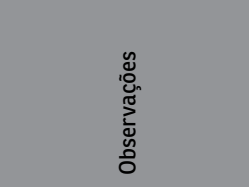 \\
\hline DAP 201 & J.D. & M & 35 & Branca & Italiana & & Viúvo & Lavrador & & & $\begin{array}{l}\text { Araraqua- } \\
\text { ra, SP }\end{array}$ & $9 / 15 / 1929$ & $9 / 27 / 1960$ & Óbito & $\begin{array}{l}\text { Fotografia } \\
\text { e digitais }\end{array}$ & Parafrenia & $\begin{array}{l}\text { Réu, por } \\
\text { homicídio } \\
\text { contra a } \\
\text { esposa. }\end{array}$ & \\
\hline DAP 213 & J.P.C. & M & 38 & Branca & Brasileira & $\begin{array}{l}\text { Ca- } \\
\text { nanéia, } \\
\text { SP }\end{array}$ & Casado & Barbeiro & Católica & $\begin{array}{l}\text { Alfabetizado } \\
\text { (primário) }\end{array}$ & Iguape, SP & $9 / 26 / 1929$ & $8 / 18 / 1931$ & $\begin{array}{l}\text { Trans- } \\
\text { ferência } \\
\text { para a } \\
\text { Cadeia } \\
\text { Pública }\end{array}$ & Fotografia & & Réu & $\begin{array}{l}\text { Preso após ferir um } \\
\text { cliente, em sua bar- } \\
\text { bearia. }\end{array}$ \\
\hline 152 & F. A. 0 & M & 37 & Branca & Brasileira & & Solteiro & Roceiro & & & $\begin{array}{l}\text { Capão } \\
\text { Bonito, SP }\end{array}$ & $10 / 4 / 1929$ & $6 / 18 / 1947$ & Óbito & $\begin{array}{l}\text { Fotografia } \\
\text { e digitais }\end{array}$ & $\begin{array}{l}\text { Esquizofrenia. } \\
\text { "A criação de } \\
\text { um mundo } \\
\text { imaginário, ou } \\
\text { autista; no qual } \\
\text { vive encapsu- } \\
\text { lado todo seu } \\
\text { raciocínio". }\end{array}$ & $\begin{array}{l}\text { Réu, por } \\
\text { homicídio } \\
\text { contra um } \\
\text { colega de } \\
\text { trabalho. }\end{array}$ & $\begin{array}{l}\text { Manteve-se isolado } \\
\text { dos outros pacientes } \\
\text { e demonstrava pouco } \\
\text { interesse. Havia sido } \\
\text { internado em 1921. } \\
\text { Afirma ter matado um } \\
\text { homem por questã de } \\
\text { namoro. Comporta- } \\
\text { mento agressivo. }\end{array}$ \\
\hline 161 & F. M. F & M & 34 & Branca & Brasileira & $\begin{array}{l}\text { Bebedou- } \\
\text { ro, SP }\end{array}$ & Casado & Dentista & & Superior & $\begin{array}{l}\text { Caceia } \\
\text { Pública da } \\
\text { Capital, } \\
\text { SP }\end{array}$ & $10 / 8 / 1929$ & $\begin{array}{l}10 / 06 / 1931 \\
\mathrm{e} \\
21 / 05 / 1963\end{array}$ & Óbito & \begin{tabular}{|l} 
Fotografia \\
e digitais
\end{tabular} & $\begin{array}{l}\text { Psicose manía- } \\
\text { co-depressiva }\end{array}$ & & $\begin{array}{l}\text { Na juventude, fora } \\
\text { internado por agressi- } \\
\text { vidade no Hospital Cen- } \\
\text { tral do Exercito. Atirou } \\
\text { em um homem, por } \\
\text { conta de uma vitrola. } \\
\text { Crises nervosas, após a } \\
\text { morte do pai. Apresen- } \\
\text { ta boa orientação no } \\
\text { lugar, tempo e meio. }\end{array}$ \\
\hline 52 & A. D. F & M & 48 & Branca & Brasileira & Tatuí, SP & Casado & Lavrador & & Analfabeto & $\begin{array}{l}\text { Botucatu, } \\
\text { SP }\end{array}$ & $11 / 29 / 1929$ & & & Fotografia & $\begin{array}{l}\text { Débil mental, } \\
\text { alcoolista. }\end{array}$ & $\begin{array}{l}\text { Réu, por } \\
\text { homicídio } \\
\text { contra a } \\
\text { esposa. }\end{array}$ & $\begin{array}{l}\text { Preso, anteriormente, } \\
\text { por assassinar três pes- } \\
\text { soas, devido a "razōes } \\
\text { comerciais". Fugiu, em } \\
\text { 1934, recapturado em } \\
16 / 08 / 1935 . \text { Cartas } \\
\text { anexadas. }\end{array}$ \\
\hline DAP 196 & J.B.A. & M & 27 & Branca & Brasileira & $\begin{array}{l}\text { Piram- } \\
\text { bóia, SP }\end{array}$ & Solteiro & Lavrador & & Alfabetizado & $\begin{array}{l}\text { Botucatu, } \\
\text { SP }\end{array}$ & $1 / 12 / 1930$ & $7 / 9 / 1937$ & Óbito & \begin{tabular}{|l} 
Fotografia \\
e digitais
\end{tabular} & $\begin{array}{l}\text { Personalidade } \\
\text { psicopática }\end{array}$ & $\begin{array}{l}\text { Réu (arts. } \\
294 \$ 2^{\circ} \text { e } \\
303), \text { por } \\
\text { homicídio. }\end{array}$ & $\begin{array}{l}\text { Cópia de partes do } \\
\text { processo criminal. }\end{array}$ \\
\hline
\end{tabular}




\begin{tabular}{|c|c|c|c|c|c|c|c|c|c|c|c|c|c|c|c|c|c|c|}
\hline 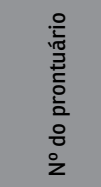 & 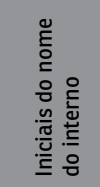 & 今̊̀ & $\begin{array}{l}\frac{\pi}{\pi} \\
\frac{\pi}{0}\end{array}$ & ¿̀ & $\begin{array}{l}\frac{\pi}{\pi} \\
\frac{\pi}{0} \\
\frac{\pi}{\pi} \\
\frac{0}{0} \\
\frac{\pi}{2} \\
\frac{\pi}{2}\end{array}$ & 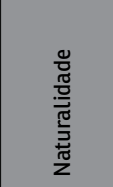 & 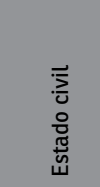 & 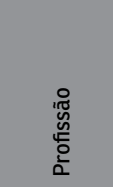 & $\frac{10}{\square}$ & 空 & 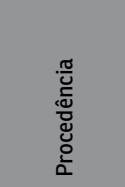 & 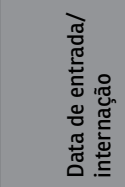 & 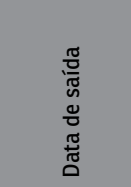 & 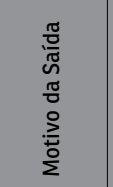 & 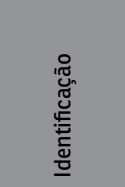 & 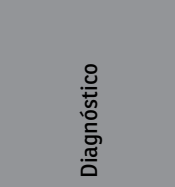 & 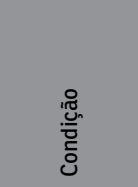 & 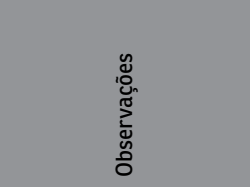 \\
\hline DAP 336 & P.A.D. & M & 37 & Branca & Brasileira & $\begin{array}{l}\text { São Pau- } \\
\text { lo, SP }\end{array}$ & Casado & $\begin{array}{l}\text { Professor } \\
\text { público }\end{array}$ & $\begin{array}{l}\text { Sem } \\
\text { religião }\end{array}$ & Alfabetizado & $\begin{array}{l}\text { Itapetinin- } \\
\text { ga, SP }\end{array}$ & $2 / 11 / 1930$ & $11 / 16 / 1949$ & $\begin{array}{l}\text { Trans- } \\
\text { ferência } \\
\text { para o } \\
\text { Hospital } \\
\text { do Ju- } \\
\text { query }\end{array}$ & $\begin{array}{l}\text { Fotografia } \\
\text { e digitais }\end{array}$ & $\begin{array}{l}\text { Síndrome de } \\
\text { influência }\end{array}$ & $\begin{array}{l}\text { Homicídio } \\
\text { contra uma } \\
\text { filha. }\end{array}$ & $\begin{array}{l}\text { Matou uma filha e } \\
\text { agrediu outra. Há } \\
\text { muitas cartas da } \\
\text { esposa, no prontuário, } \\
\text { e orçamento de gastos } \\
\text { do interno. Carta à es- } \\
\text { posa, na se declara sem } \\
\text { religião e anarquista. } \\
\text { Pede para queimar seu } \\
\text { diploma de professor e } \\
\text { de maçom. Pede uma } \\
\text { Bíblia. }\end{array}$ \\
\hline DAP 022 & J.S.B. & M & 19 & Parda & Brasileira & $\begin{array}{l}\text { Franca, } \\
\text { SP }\end{array}$ & Solteiro & $\begin{array}{l}\text { Serven- } \\
\text { te de } \\
\text { pedreiro }\end{array}$ & & Analfabeto & Franca, SP & $4 / 7 / 1930$ & $3 / 27 / 1958$ & $\begin{array}{l}\text { Trans- } \\
\text { ferência } \\
\text { para o } \\
\text { Hospital } \\
\text { do Ju- } \\
\text { query }\end{array}$ & $\begin{array}{l}\text { Fotografia } \\
\text { e digitais }\end{array}$ & $\begin{array}{l}\text { Estado atípico } \\
\text { de degenera- } \\
\text { ção, psicopatia. }\end{array}$ & $\begin{array}{l}\text { Réu, (art. } \\
\text { 29) por } \\
\text { tentativa de } \\
\text { homicídio. }\end{array}$ & $\begin{array}{l}\text { Tísico e portador de } \\
\text { cegueira. }\end{array}$ \\
\hline DAP 369 & S.P.A. & M & 40 & Branca & Brasileira & $\begin{array}{l}\text { Bananal, } \\
\text { SP }\end{array}$ & Viúvo & $\begin{array}{l}\text { Jorna- } \\
\text { leiro }\end{array}$ & & Analfabeto & $\begin{array}{l}\text { São José } \\
\text { do Barrei- } \\
\text { ro, SP }\end{array}$ & $4 / 15 / 1930$ & $11 / 3 / 1931$ & $\begin{array}{l}\text { Trans- } \\
\text { ferência } \\
\text { para São } \\
\text { José do } \\
\text { Barreiro }\end{array}$ & Fotografia & $\begin{array}{l}\text { Delírio } \\
\text { persecutório } \\
\text { místico, de base } \\
\text { alucinatória e } \\
\text { interpretativa }\end{array}$ & $\begin{array}{l}\text { Réu (art. } \\
\text { 303), por } \\
\text { crime de } \\
\text { ferimentos } \\
\text { leves. }\end{array}$ & $\begin{array}{l}\text { Cópia de partes do pro- } \\
\text { cesso criminal e oficios } \\
\text { para a internação. }\end{array}$ \\
\hline DAP 092 & B.P.O. & M & 26 & Parda & Brasileira & $\begin{array}{l}\text { Socorro, } \\
\text { SP }\end{array}$ & Casado & & & & $\begin{array}{l}\text { Cadeia de } \\
\text { Socorro, } \\
\text { SP }\end{array}$ & $4 / 29 / 1930$ & $6 / 7 / 1931$ & & Fotografia & $\begin{array}{l}\text { Não sofre de } \\
\text { alienaçāo } \\
\text { mental. Surto } \\
\text { epiléptico }\end{array}$ & $\begin{array}{l}\text { Réu, por } \\
\text { homicídio. }\end{array}$ & $\begin{array}{l}\text { Cópia de partes do } \\
\text { processo criminal. }\end{array}$ \\
\hline DAP 358 & R.A. & M & 26 & Preta & Brasileira & $\begin{array}{l}\text { Piracica- } \\
\text { ba, SP }\end{array}$ & Solteiro & Operário & Católica & Alfabetizado & $\begin{array}{l}\text { Cadeia } \\
\text { Pública da } \\
\text { Capital, } \\
\text { SP }\end{array}$ & 6/10/1930 & $6 / 3 / 1931$ & $\begin{array}{l}\text { Trans- } \\
\text { ferência } \\
\text { para a } \\
\text { Cadeia } \\
\text { Pública } \\
\text { da } \\
\text { Capital }\end{array}$ & Fotografia & $\begin{array}{l}\text { Ausência de } \\
\text { qualquer dis- } \\
\text { túrbio psíquico }\end{array}$ & $\begin{array}{l}\text { Réu (art. } \\
294 \text { do Có- } \\
\text { digo Penal } \\
\left.\$ 1^{\circ}\right) \text {, por } \\
\text { crime de } \\
\text { homicídio. }\end{array}$ & $\begin{array}{l}\text { Cópia de partes do } \\
\text { processo criminal, } \\
\text { recorte de jornal e um } \\
\text { questionário sobre o } \\
\text { interno, respondido } \\
\text { pela irma.. }\end{array}$ \\
\hline DAP 148 & F.P. & M & 32 & Branca & $\begin{array}{l}\text { Espa- } \\
\text { nhola }\end{array}$ & $\begin{array}{l}\text { Badajoz } \\
\text { Espanha }\end{array}$ & Casado & Roceiro & Católica & $\begin{array}{l}\text { Alfabetizado } \\
\text { (rudimentar) }\end{array}$ & $\begin{array}{l}\text { Araçatuba, } \\
\text { SP }\end{array}$ & $6 / 17 / 1930$ & 3/17/1938 & $\begin{array}{l}\text { Trans- } \\
\text { ferência } \\
\text { para a } \\
\text { Cadeia } \\
\text { de Ara- } \\
\text { çatuba }\end{array}$ & $\begin{array}{l}\text { Fotografia } \\
\text { e digitais }\end{array}$ & & $\begin{array}{l}\text { Réu, por } \\
\text { homicídio. }\end{array}$ & $\begin{array}{l}\text { Cópia do processo } \\
\text { criminal. Embora, na } \\
\text { Comarca de Araçatuba, } \\
\text { o réu tenha respondido } \\
\text { não saber ler nem } \\
\text { escrever, o prontuário } \\
\text { contém uma carta do } \\
\text { mesmo, remetida ao } \\
\text { manicômio. Cartas do } \\
\text { cunhado e da esposa. }\end{array}$ \\
\hline
\end{tabular}




\begin{tabular}{|c|c|c|c|c|c|c|c|c|c|c|c|c|c|c|c|c|c|c|}
\hline 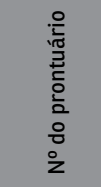 & 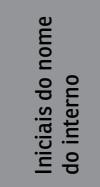 & ঙ̊̀̀ & $\begin{array}{l}\frac{\pi}{\pi} \\
\frac{\pi}{0}\end{array}$ & ò & $\begin{array}{l}\frac{\pi}{\pi} \\
\frac{\pi}{\pi} \\
\frac{\pi}{\pi} \\
\frac{0}{\overline{0}} \\
\frac{\pi}{2}\end{array}$ & 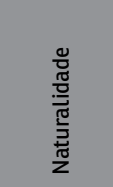 & 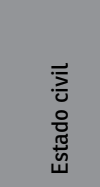 & 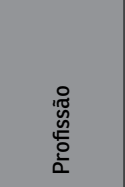 & : & 悹 & 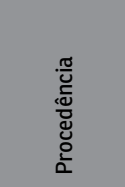 & 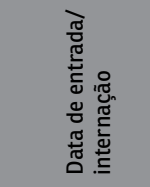 & 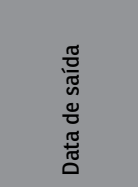 & 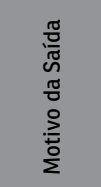 & 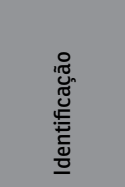 & 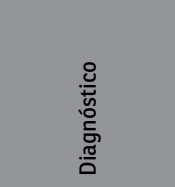 & 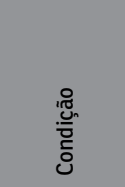 & 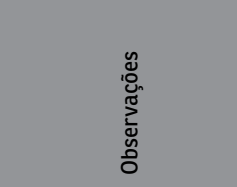 \\
\hline DAP 053 & A.D.F. & M & 18 & Branca & Brasileira & $\begin{array}{l}\text { Pernam- } \\
\text { buco }\end{array}$ & Solteiro & Operário & Católica & $\begin{array}{l}\text { Alfabetizado } \\
\text { (rudimentar) }\end{array}$ & $\begin{array}{l}\text { Cadeia } \\
\text { Pública da } \\
\text { Capital, } \\
\text { SP }\end{array}$ & $6 / 22 / 1930$ & 8/16/1931 & $\begin{array}{l}\text { Trans- } \\
\text { ferência } \\
\text { para a } \\
\text { Cadeia } \\
\text { Pública } \\
\text { da } \\
\text { Capital }\end{array}$ & Fotografia & Sifilítico & $\begin{array}{l}\text { Réu, por } \\
\text { furto. }\end{array}$ & $\begin{array}{l}\text { Cópia do depoimento } \\
\text { das testemunhas no } \\
\text { processo criminal. }\end{array}$ \\
\hline DAP136 & E.P. & M & 20 & Branca & Brasileira & $\begin{array}{l}\text { São Ro- } \\
\text { que, SP }\end{array}$ & Solteiro & Indefinida & Católica & $\begin{array}{l}\text { Alfabetizado } \\
\text { (primário) }\end{array}$ & $\begin{array}{l}\text { Instituto } \\
\text { Corre- } \\
\text { cional, } \\
\text { Taubaté, } \\
\text { SP }\end{array}$ & $7 / 6 / 1930$ & 2/2/1932 & $\begin{array}{l}\text { Trans- } \\
\text { ferência } \\
\text { para o } \\
\text { Hospital } \\
\text { do Ju- } \\
\text { query }\end{array}$ & Fotografia & Imbecilidade & $\begin{array}{l}\text { Réu, por } \\
\text { furto e } \\
\text { vadiagem. }\end{array}$ & $\begin{array}{l}\text { Atestado policial } \\
\text { informa ser indigente. }\end{array}$ \\
\hline DAP 205 & J.G.M. & M & 34 & Branca & Brasileira & $\begin{array}{l}\text { Peder- } \\
\text { neiras, } \\
\text { SP }\end{array}$ & Casado & Lavrador & Católica & Alfabetizado & Bauru, SP & $7 / 20 / 1930$ & 2/12/1931 & Óbito & $\begin{array}{l}\text { Fotografia } \\
\text { e assina- } \\
\text { tura }\end{array}$ & $\begin{array}{l}\text { Síndrome } \\
\text { depressivo }\end{array}$ & $\begin{array}{l}\text { Réu (art. } \\
294 \text { do Có- } \\
\text { digo Penal } \\
\$ 1^{\circ} \text {, por } \\
\text { homicídio. }\end{array}$ & $\begin{array}{l}\text { Três atestados do } \\
\text { interno, em outras } \\
\text { clínicas. Cópia de } \\
\text { partes do processo } \\
\text { criminal. Questionário } \\
\text { do interno, respondido } \\
\text { pelo marido da } \\
\text { sobrinha. }\end{array}$ \\
\hline DAP 180 & J. L. & M & 29 & Branca & $\begin{array}{l}\text { Portu- } \\
\text { guesa }\end{array}$ & $\begin{array}{l}\text { Itha da } \\
\text { Madeira, } \\
\text { Portugal }\end{array}$ & Viúvo & Operário & Católica & Analfabeto & $\begin{array}{l}\text { Cadeia } \\
\text { Pública da } \\
\text { Capital, } \\
\text { SP }\end{array}$ & $\begin{array}{l}16 / 11 / 1930 \text { e } \\
28 / 11 / 1947\end{array}$ & $\begin{array}{l}\text { 19/04/1931, } \\
19 / 11 / 1939, \\
09 / 03 / 1949 \\
\mathrm{e} \\
21 / 03 / 1947\end{array}$ & $\begin{array}{l}\text { Trans- } \\
\text { ferência } \\
\text { para } \\
\text { peniten- } \\
\text { ciária }\end{array}$ & $\begin{array}{l}\text { Fotografia } \\
\text { e digitais }\end{array}$ & Esquizofrenia & $\begin{array}{l}\text { Réu (art. } \\
294 \text { do } \\
\text { Código } \\
\text { Penal), por } \\
\text { homicídio. }\end{array}$ & $\begin{array}{l}\text { Cópia de partes do } \\
\text { processo criminal. } \\
\text { Recortes de jornal. }\end{array}$ \\
\hline DAP 309 & M.M. & M & 23 & Preta & Brasileira & $\begin{array}{l}\text { Minas } \\
\text { Gerais }\end{array}$ & Solteiro & Lavrador & & Alfabetizado & $\begin{array}{l}\text { Instituto } \\
\text { Corre- } \\
\text { cional de } \\
\text { Taubaté, } \\
\text { SP }\end{array}$ & $12 / 13 / 1930$ & $\begin{array}{l}24 / 10 / 1951 \\
\mathrm{e} \\
18 / 02 / 1957\end{array}$ & $\begin{array}{l}\text { Trans- } \\
\text { ferência } \\
\text { para o } \\
\text { Hospi- } \\
\text { tal do } \\
\text { Juquery } \\
\text { e óbito }\end{array}$ & $\begin{array}{l}\text { Fotografia } \\
\text { e digitais }\end{array}$ & $\begin{array}{l}\text { Demência } \\
\text { precoce, esqui- } \\
\text { zofrenia. }\end{array}$ & $\begin{array}{l}\text { Senten- } \\
\text { ciado (art. } \\
\text { 399). }\end{array}$ & \\
\hline DAP 056 & O.L. & M & 21 & Branca & Italiana & $\begin{array}{l}\text { Luca, } \\
\text { Itália }\end{array}$ & Solteiro & $\begin{array}{l}\text { Serven- } \\
\text { te de } \\
\text { pedreiro }\end{array}$ & & Alfabetizado & $\begin{array}{l}\text { Instituto } \\
\text { Corre- } \\
\text { cional, } \\
\text { Taubaté, } \\
\text { SP }\end{array}$ & $12 / 13 / 1930$ & $2 / 2 / 1932$ & & Fotografia & $\begin{array}{l}\text { Demência } \\
\text { precoce }\end{array}$ & $\begin{array}{l}\text { Réu, por } \\
\text { vadiagem. }\end{array}$ & $\begin{array}{l}\text { Exames de sangue, } \\
\text { fezes e líquido } \\
\text { cefalorraquidiano. }\end{array}$ \\
\hline DAP 276 & К.M. & $\mathrm{F}$ & 45 & $\begin{array}{l}\text { Ama- } \\
\text { rela }\end{array}$ & Japonesa & & Viúva & $\begin{array}{l}\text { Serviços } \\
\text { domésti- } \\
\text { cos }\end{array}$ & Católica & Analfabeta & $\begin{array}{l}\text { Presidente } \\
\text { Prudente, } \\
\text { SP }\end{array}$ & $12 / 20 / 1930$ & 1/24/1931 & $\begin{array}{l}\text { Trans- } \\
\text { ferência } \\
\text { para o } \\
\text { Hospi- } \\
\text { tal do } \\
\text { Juquery } \\
\text { e óbito }\end{array}$ & & $\begin{array}{l}\text { Demência } \\
\text { precoce }\end{array}$ & Ré & $\begin{array}{l}\text { Questionário } \\
\text { respondido pelo filho. }\end{array}$ \\
\hline
\end{tabular}




\begin{tabular}{|c|c|c|c|c|c|c|c|c|c|c|c|c|c|c|c|c|c|c|}
\hline 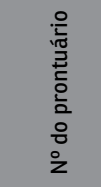 & 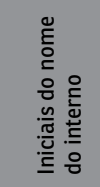 & ֻั̊ั & 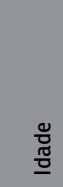 & ¿̀ & $\begin{array}{l}\frac{\pi}{\pi} \\
\frac{\pi}{\pi} \\
\frac{\pi}{\pi} \\
\frac{0}{0} \\
\frac{\pi}{2}\end{array}$ & 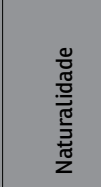 & 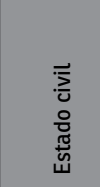 & 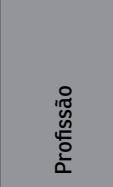 & 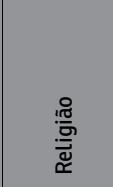 & 突 & 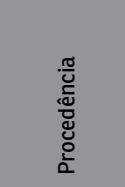 & 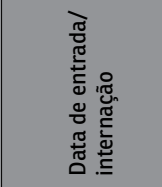 & $\begin{array}{l}\frac{\pi}{\pi} \\
\frac{0}{\pi} \\
0 \\
0 \\
\frac{\pi}{\pi} \\
0\end{array}$ & $\begin{array}{l}\frac{\pi}{0} \\
\frac{\pi}{\pi} \\
\frac{\pi}{0} \\
0 \\
\stackrel{0}{0} \\
\sum\end{array}$ & 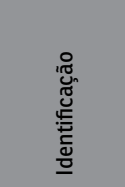 & 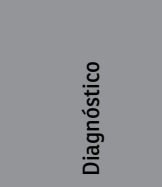 & 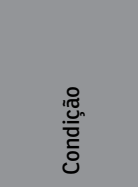 & 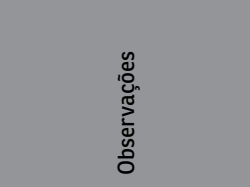 \\
\hline DAP 083 & B.o. & M & 23 & Branca & Italiana & $\begin{array}{l}\text { Rovigo, } \\
\text { Itália }\end{array}$ & Solteiro & & Católica & & & $\begin{array}{l}01 / 07 / 1904 \text { e } \\
13 / 06 / 1909\end{array}$ & $\begin{array}{l}17 / 10 / 1908 \\
\mathrm{e} \\
13 / 09 / 1931\end{array}$ & $\begin{array}{l}\text { Trans- } \\
\text { ferência } \\
\text { para a } \\
\text { Peniten- } \\
\text { ciária do } \\
\text { Estado }\end{array}$ & Fotografia & $\begin{array}{l}\text { Epilepsia } \\
\text { paralítica }\end{array}$ & $\begin{array}{l}\text { Condenado } \\
\text { a } 9 \text { anos } \\
\text { e } 4 \text { meses } \\
\text { de prisão } \\
\text { e multa } \\
\text { de } 1 / 3 \text { do } \\
\text { valor dos } \\
\text { objetos } \\
\text { roubados } \\
\text { (arts. } \\
356 \text { e } 66, \\
\text { segundo } \\
\text { parágrafo). }\end{array}$ & $\begin{array}{l}\text { Revela boa memó- } \\
\text { ria para números e } \\
\text { fatos. Dez irmāos, dois } \\
\text { falecidos. Julgava-se } \\
\text { perseguido, acreditava } \\
\text { haver venenos na } \\
\text { comida, e ouvia vozes. } \\
\text { Prestava serviços na } \\
\text { padaria do hospital. }\end{array}$ \\
\hline DAP 256 & J.J. & M & 29 & Branca & Síria & Síria & Casado & Operário & Católica & Analfabeto & & $\begin{array}{l}\text { 05/08/1920 e } \\
20 / 01 / 1951\end{array}$ & $2 / 2 / 1932$ & & $\begin{array}{l}\text { Fotografia, } \\
\text { medidas } \\
\text { corporais, } \\
\text { assinatura } \\
\text { e digitais }\end{array}$ & $\begin{array}{l}\text { Debilidade } \\
\text { mental, } \\
\text { alcoolismo e } \\
\text { oligofrenia. }\end{array}$ & $\begin{array}{l}\text { Condenado } \\
\text { (art. 294 } \\
\text { do Código } \\
\text { Penal, } \$ 2^{\circ} \\
\text { do Código } \\
\text { Penal). }\end{array}$ & $\begin{array}{l}\text { Pensamentos tolos, } \\
\text { sem compostura. } \\
\text { Alude ao seu crime com } \\
\text { naturalidade mórbida, } \\
\text { confessa uso de álcool. } \\
\text { Na segunda internaçāo, } \\
\text { nega o crime e o uso } \\
\text { de álcool. Relaçāo dos } \\
\text { objetos que portava, } \\
\text { no momento da inter- } \\
\text { naçāo. }\end{array}$ \\
\hline DAP 294 & M.A.P. & $\mathrm{F}$ & 22 & Branca & Brasileira & & Viúva & $\begin{array}{l}\text { Domés- } \\
\text { tica }\end{array}$ & & $\begin{array}{l}\text { Alfabetizada } \\
\text { (primário) }\end{array}$ & $\begin{array}{l}\text { Cadeia } \\
\text { Pública da } \\
\text { Capital, } \\
\text { SP }\end{array}$ & $\begin{array}{l}\text { 09/05/1927 e } \\
24 / 05 / 1929\end{array}$ & $\begin{array}{l}20 / 02 / 1929 \\
\mathrm{e} \\
30 / 12 / 1939\end{array}$ & $\begin{array}{l}\text { Entre- } \\
\text { gue à } \\
\text { família }\end{array}$ & Fotografia & Loucura moral & $\begin{array}{l}\text { Absolvida, } \\
\text { por homicí- } \\
\text { dio contra } \\
\text { o marido. }\end{array}$ & $\begin{array}{l}\text { Foge e retorna. Em } \\
\text { 1939, é entregue à } \\
\text { família. "Problemas } \\
\text { de conduta", desde a } \\
\text { infância. Recortes de } \\
\text { jornais. Definição de } \\
\text { "loucura moral", para o } \\
\text { diagnóstico do interno. } \\
\text { Questionário respondi- } \\
\text { do por seu pai. }\end{array}$ \\
\hline DAP 192 & J.B.A. & M & 36 & Preta & Brasileira & Itu, SP & Solteiro & Lavrador & & $\begin{array}{l}\text { Alfabetizado } \\
\text { (assina o } \\
\text { nome) }\end{array}$ & $\begin{array}{l}\text { São Paulo, } \\
\text { SP }\end{array}$ & $14 / 06 / 1903$ & & & $\begin{array}{l}\text { Arcada } \\
\text { dentária }\end{array}$ & $\begin{array}{l}\text { Síndrome } \\
\text { demencial, } \\
\text { delírio crônico } \\
\text { sistemático. }\end{array}$ & $\begin{array}{l}\text { Condenado } \\
\text { pelo Júri } \\
\text { de Casa } \\
\text { Branca a } \\
15 \text { anos, } \\
6 \text { meses } \\
\text { e } 20 \text { dias } \\
\text { de prisão } \\
\text { celular, por } \\
\text { crime de } \\
\text { homicídio. }\end{array}$ & $\begin{array}{l}\text { Incoerência, ilogismo, } \\
\text { baixa capacidade } \\
\text { intelectual, conceitos } \\
\text { pueris, memória pre- } \\
\text { judicada, desconhece o } \\
\text { motivo da prisão e apa- } \\
\text { tia. "Ā direita, a visão } \\
\text { é nula e, à esquerda, } \\
\text { é baixíssima". Cinco } \\
\text { irmãos com paradeiros } \\
\text { desconhecidos. }\end{array}$ \\
\hline
\end{tabular}




\begin{tabular}{|c|c|c|c|c|c|c|c|c|c|c|c|c|c|c|c|c|c|c|}
\hline 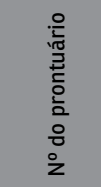 & 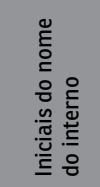 & §̊̀ & $\begin{array}{l}\text { 苋 } \\
\text { 吾 }\end{array}$ & ò & $\begin{array}{l}\frac{\pi}{\pi} \\
\frac{\pi}{0} \\
\frac{\pi}{\pi} \\
\frac{0}{\overline{0}} \\
\frac{\pi}{2}\end{array}$ & $\begin{array}{l}\frac{8}{\pi} \\
\frac{\pi}{0} \\
\frac{\pi}{\pi} \\
\frac{\pi}{2} \\
\frac{\pi}{2}\end{array}$ & 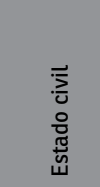 & 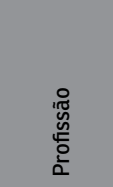 & $\frac{10}{\square}$ & 窵 & 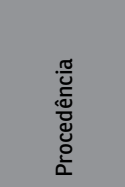 & 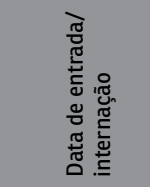 & 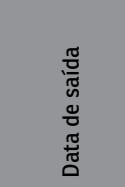 & 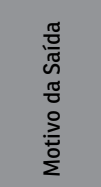 & 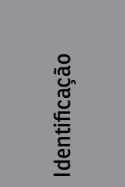 & 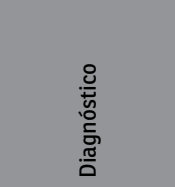 & 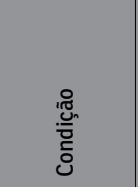 & 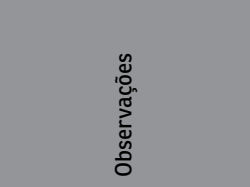 \\
\hline DAP 238 & J.C. & M & 32 & Preta & Brasileira & & Solteiro & & Católica & & $\begin{array}{l}\text { Peniten- } \\
\text { ciária do } \\
\text { Estado, } \\
\text { SP }\end{array}$ & $\begin{array}{l}15 / 10 / 1920 \text { e } \\
27 / 09 / 1924\end{array}$ & $5 / 30 / 1924$ & $\begin{array}{l}\text { Trans- } \\
\text { ferência } \\
\text { para a } \\
\text { peniten- } \\
\text { ciária/ } \\
\text { fuga }\end{array}$ & Fotografia & $\begin{array}{l}\text { Demência pre- } \\
\text { coce paranoide }\end{array}$ & $\begin{array}{l}\text { Sentencia- } \\
\text { do, por ten- } \\
\text { tativa de } \\
\text { homicídio. }\end{array}$ & $\begin{array}{l}\text { Exames de fezes, } \\
\text { reação de Wassermann, } \\
\text { líquido cefalorraquidia- } \\
\text { no. Ficha da Seção de } \\
\text { Medicina e Criminolo- } \\
\text { gia da penitenciária. }\end{array}$ \\
\hline DAP 260 & J.M. & M & 30 & Preta & Brasileira & & Casado & Lavrador & Católica & Analfabeto & $\begin{array}{l}\text { Descalva- } \\
\text { do, SP }\end{array}$ & $190 / 3 / 1922$ & 8/13/1937 & Óbito & Fotografia & $\begin{array}{l}\text { Epilepsia, } \\
\text { mania de } \\
\text { perseguição, } \\
\text { alcoólatra e } \\
\text { irritadiço. }\end{array}$ & $\begin{array}{l}\text { Senten- } \\
\text { ciado }\end{array}$ & $\begin{array}{l}\text { Guia e cópia de partes } \\
\text { do processo criminal. }\end{array}$ \\
\hline DAP 316 & N.T. & M & 33 & Branca & Italiana & & Solteiro & $\begin{array}{l}\text { Doma- } \\
\text { dor de } \\
\text { cavalos }\end{array}$ & Católica & $\begin{array}{l}\text { Alfabetizado } \\
\text { (assina o } \\
\text { nome) }\end{array}$ & $\begin{array}{l}\text { São Paulo, } \\
\text { SP }\end{array}$ & $\begin{array}{l}30 / 01 / 1920 \mathrm{e} \\
01 / 09 / 1920\end{array}$ & & & $\begin{array}{l}\text { Foto- } \\
\text { grafias, } \\
\text { exames } \\
\text { psíquicos } \\
\text { e medidas } \\
\text { corporais }\end{array}$ & & & $\begin{array}{l}\text { Boa noção de tempo e } \\
\text { espaço. Afirma ter tro- } \\
\text { cado de nome, quando } \\
\text { processado pelo crime } \\
\text { de repasse de notas } \\
\text { falsas. }\end{array}$ \\
\hline
\end{tabular}

